UNIVERSIDADE DE SÃO PAULO

INSTITUTO DE GEOCIÊNCIAS

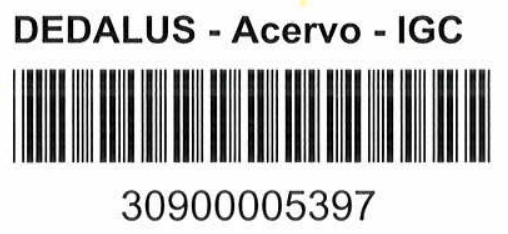

T1104

\title{
SEDIMENTAC̄̃̃O ATUAL APLICADA A PORTOS NO BRASIL
}

\author{
WALDIR LOPES PONÇANO
}

ORIENTADOR:PROF.DR. VICENTE JOSÉ FÚLFARO

Tese de Doutoramento

COMISSÃO EXAMINADORA

nome

Presidente:

Examinadores:
Vicente J. Fülfaro

Armando M. Coimbra

Miltan Kanji

Waldenir V. Furtado

José E. Farjallat ass.

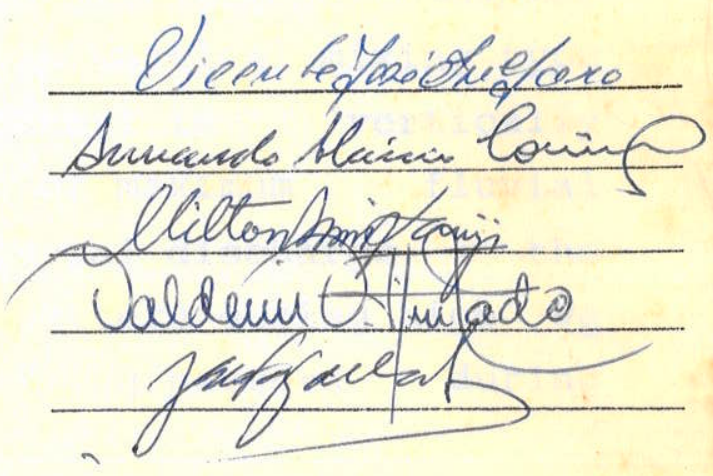


This work presents sedimentological investigations neces sary to port assessment and planning, as referred to a framework of quaternary geological events. Among these the most important are believed to be the valley-cutting which took place during the würm epoch and subsequent sea-level changes.

Investigations were carried out on the vicinities of Guarás Island (PA), or Tainheiros (BA), Aratu (BA) and Sepetiba (RJ) Bays and on Potengi (RN), Santos (SP) and Itajaí-Açu (SC) estu aries.

Studies undertaken in the Guarás Island region were essenti ally cartographic, based on analyses of bathymetric charts and aerial photographs. Results have shown migration of channels, al though their depths have been maintained throughout the investigated span of time. The inferred displacements of the channels agree with features of accretion observed in emergent surfaces.

In Tainheiros, Aratu and Sepetiba Bays, cartographic and remote-sensing observations were a first step, to be complemented by sistematic sampling and analysis of bottom sediments. In these cases the regional pattern of sediment and water circulation, most ly governed by paleo-valleys distribution, proved to be an impor tant factor in determining erosion/accretion sites.

In the studied estuaries stress has been put in the charac terization of both and suspended sediments, as well as in water salinity, as guidelines to establish the types of estuarine circulation. This approach was developed in more detail for santos and Itajai-Açu estuaries. Fluvial influence grows increasingly from Potengi to Santos to Itajai-Açu estuaries; there are no definite data to classify the first one of them, although its situation suggests a vertically mixed type. For the porto Channel of the Santos estuary a two-layer flow with vertical mixing type was determined, whilst the são Vicente channel is vertically homogeneous, both under summer conditions of maximum fluvial discharge. Under conditions of minimum fluvial discharge the Itajaî-Açu estuary displays a salt-wedge pattern during high wa ter, and a two-layer flow with vertical mixing pattern during 
the low water, both for spring tide.

Time-dependent changes in granulometric characteristics of bottom sediment were investigated for Santos Bay and Itajai-Açu estuary, this latter case including a catastrophic flooding.

Some methodological review has been made, including remarks on the possibilities of dynamic interpretation of graim-size statistical parameters. Data from 588 samples are highly suggestive that square-deviation, skewness and kurtosis depend on the consi dered mean size of the sediment. 
RESUMO

As características da sedimentação atual em áreas de inte resse à implantação/manutenção de portos são aqui apresentadas sob a perspectiva da história geológica mais recente, especialmente quaternária. Desta, destacam-se como eventos mais importantes os entalhes würmianos e subsequlentes oscilações do nível marinho,que, a par de fatores tectônicos, explicam os principais traços da dis tribuição e conformação dos corpos d'ãgua costeiros.

As investigações abrangeram as proximidades da Ilha dos Gua rás (PA), a Baỉa de Sepetiba (RJ), Enseada dos Tainheiros e Baỉa de Aratu, na Baía de Todos os Santos (BA), e os estuários do Po tengi (RN), de Santos (SP) e do Itajaí-Açu (SC).

$\mathrm{Na}$ região de Guarás procedeu-se a estudo essencialmente car tográfico, aṭavés de fotos aéreas e cartas batimétricas defasadas, tendo-se constatado que, embora as profundidades dos canais de circulação se mantivessem no tempo, seus eixos de maiores pro fundidades apresentavam migração, compatível com o crescimento ob servado em partes emersas.

Nos casos da Enseada dos Tainheiros, Baía de Aratu e Baía de Sepetiba, alēm das avaliações efetuadas a partir de cartas batimé tricas e imagens de sensores, procedeu-se a levantamento sistemātico das características dos sedimentos de superficie de fundo.Pô de-se nestes casos destacar a importância dos padrões regionais de circulação d'águas e sedimentos, relacionados por sua vez a paleo vales, na determinação das áreas mais e menos suscetíveis e ero são/deposição.

Para os estuārios, maior ênfase foi dada ao estudo dos sedi mentos de"superfície de fundo, bem como a distribuição de salini dades e material em suspensão, como indicadores da tipologia es tuarina. Esta abordagem foi particularmente desenvolvida para os èstuários de Santos e do Itajaí-Açu. A influência fluvial na cir culação estuarina aumenta do Potengi a Santos ao Itajai-Açu; no primeiro caso não há dados conclusivos sobre o tipo de circulação, embora os dados colhidos sejam sugestivos de mistura vertical. Já - Canal do Porto do estuário santista apresenta circulação em dois estratos, com mistura vertical, enquanto que o Canal de são Vicen 
te apresenta circulação verticalmente homogênea, ambos sob condições de verão, de máxima descarga fluvial. para o estuário do Ita jaî-Açu, sob cỏndições de vazões mỉnjmas, pôde-se caracterizar cir culação do tipo cunha salina para preamar, e em dois estratos com mistura vertical na baixa-mar.

Variações temporais das fácies dos sedimentos de superfície de fundo foram investigadas na Baía de Santos e, sob diversas con dições de vazão, incluindo um episōdio catastrófico, no estuārio do Itajaî-Açu.

No decorrer da exposição dos diferentes casos, são feitas diversas sugestões e revisões metodológicas. Destaque especial é dado ao problema da interpretação dinâmica dos parâmetros estatísticos granulométricos. Dados referentes a 588 amostras são altamente sugestivos de que desvio-padrão (grau de seleção), assi metria e curtose são dependentes, de modo definido e por intervalo granulométrico, do diâmetro médio. 


\section{AGRADECIMENTOS}

No decorrer de seu desenvolvimento, este trabalho contou com a colaboração de numerosas pessoas, às quais tenho a satís fação de agradecer.

Inicialmente a meụ orientador, Prof. Dr. Vicente José Fúi faro, pelo indispensável apoio e estímulo oferecidos durante todas as etapas de minha formação acadêmica; à sua originalida de de espirito deve certamente o que de interessante possa con ter esta tese.

A meu colega Antonio Fernando Gimenez, pela constante, efe tiva, amistosa participação no decorrer dos últimos dez anos, nos projetos que originaram este trabalho.

Aos colegas do Instituto de Pesquisas Tecnolögicas que, em diversos momentos prestaram-me sua colaboração: Antonio $G$. Pires Neto e Maria do Carmo S.R. dos Santos, na análise carto grāfica de Guarās, Dirceu P. Stein, no primeiro estudo de San tos, Carlos Alberto Bistrichi, em Sepetiba, Antonio Manoel $S$. Oliveira, Carlos Geraldo Luz de Freitas e Fernando X. de Tava res Salomão, no caso da Bahia. A Ely B, Frazão e Jorge K. Yamą moto.pelas anālises granulomētricas, e a Eleno de Paula Rodri gues e Maria Cristina de Moraes pela descriçāo de lâminas de pesados. A José A. Quintanilha, Lūcia Dozzi, Mário Otávio : da Costa è Saul B. Suslick pelo apoio em informātica. A Cherry Y. S. Abe e Vera M. L. Ponçano Alves Silva pelas análises de sali nidade e material em suspensão. Airton M. Santa, Floriano P. de Aquino, Otávio Martins, Waldomiro de Oliveira e, de modo espe cial, Júlio Sinkus, prestaram valiosọ apoio técnico na coleta e em parte do tratamento das amostras, a que agradeço, bem como - auxílio prestado por Manoel Roque Galvão, Märcia R.M. Saad e Maria Solange de Oliveira Pereira na pesquisa bibliográfica e recuperação de documentos.

A Dra. Elena Franzinelli meus agradecimentos pela simpática acolhida em Belém; a Moysés G. Tessler e Dr. Valdenir V. Furta do, do Instituto Oceanográfico da USP, pela obtenção de alguns documentos. Ao Prof. Dr. Gilberto Amaral, do Instituto de Geoci. 
ências da USP, e Claudio Riccomini, do IPT, pelo acesso às ima gens de satélite neste trabalho referidas.

A Lourdes M. Mioto pelo auxílio, na confecção dos volumes: a Maria Celes Moura pela datilografia e apoio administrativo.

A todos os colegas do Agrupamento de Geologia Geral do IPT, atravēs de Rosely M. Gimenez, pela profícua convivência.

Ao Instituto de Pesquisas Tecnológicas, nas pessoas de An tonio R. Rodrigues e Ricardo F. da Silva, e ao Instituto de Pes quisas Hidroviárias da PORTOBRÁs, em nome de José Antonio dos Santos, pelo apoio institucional, com agradecimentos extensivos ao pessoal da Administração do Porto de Itajaí. 


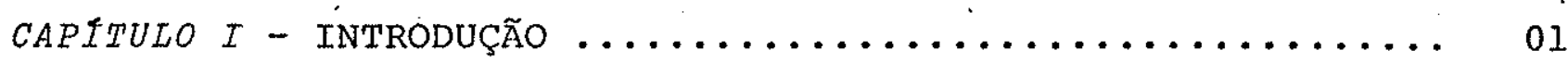

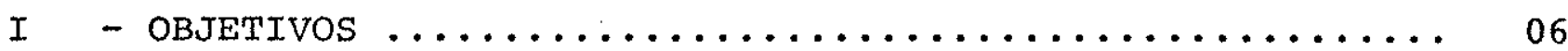

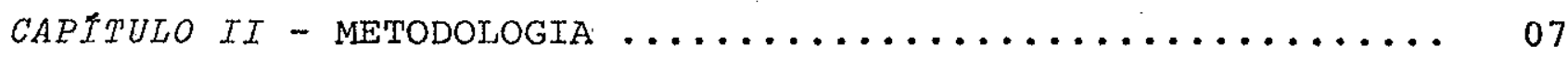

. I - PRINCIPIOS GERAIS. ........................ 07

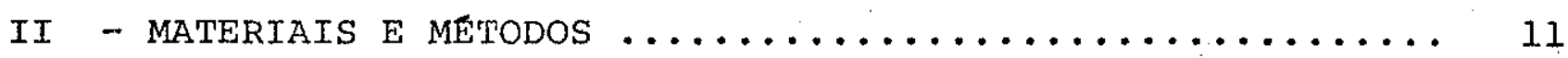

A. Plantas e Imagens de Sensores Remotos $\ldots \ldots \ldots \ldots \ldots . . \ldots 11$

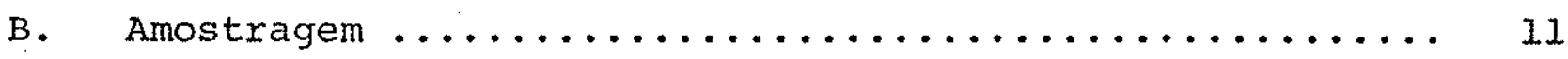

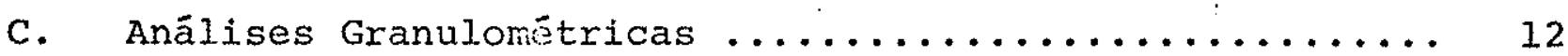

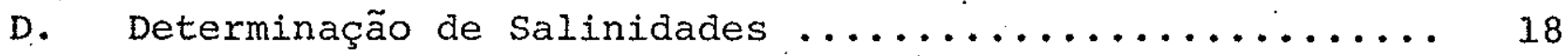

E, Determinação de Teores de Matëria Orgânica .......... 18

F. Composição Mineralógica .................... 19

G. Tratamento Estatistico de Dados $\ldots \ldots \ldots \ldots \ldots \ldots \ldots \ldots \ldots$

CAPITULO III - TERMINAIS MARITIMOS EM OFESHORE: O SITIO DE IM PLANTAÇÃO DO TERMINAL DE ILHA DOS GUARAS, ESTADO DO PA

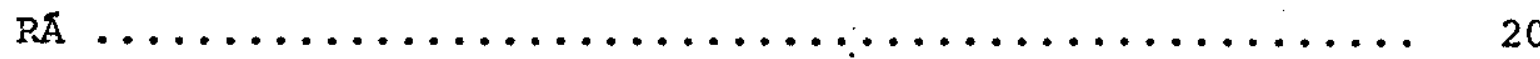

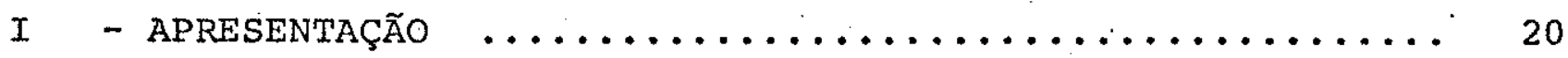

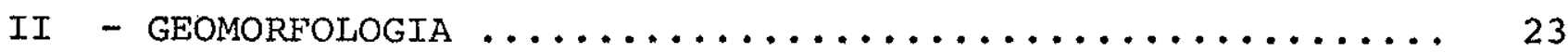

III - ANALISE DAS VARIAÇÕES DA LINHA DE COSTA $\ldots \ldots \ldots \ldots \ldots 27$

A. Comparação de Cartas naúticas $\ldots \ldots \ldots \ldots \ldots \ldots \ldots \ldots . \ldots \ldots 27$

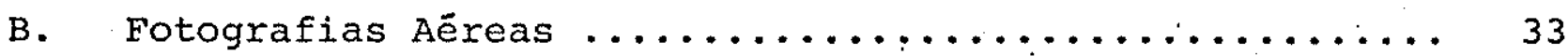

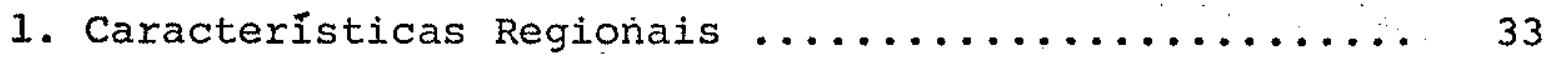

2. Ilha dos Guarás e Proximidades .............. 34

IV - ANALISE DAS VARIAÇÕES BATIMETRICAS $\ldots \ldots \ldots \ldots \ldots \ldots \ldots . \ldots \ldots$

A. Obtenção de Dados a Partir dás Cartas da DHN nos 302 e 313 e das Folhas de Bordo $\ldots \ldots \ldots \ldots \ldots \ldots \ldots \ldots \ldots . . \ldots \ldots$

B. Cálculo do Volume do Naterial Movimentado no Período 1959,1960 a 1972 . 
Pāg.

C. Discussão dos Resultados .................. 46

V. TENDENCIASS EVOLUTIVAS DA SEDIMENTAÇÃO NAS ADJACENCIAS DA ILHA DOS GUARAS

CAPIIULO IV - PORTOS E TERMINAIS EM BAIAS: OS CASOS DE SEPE TIBA, ESTADO DO RIO DE JANEIRO, ARATU E ENSEADA DOS TAINHEIROS, ESTADO DA BAHIA. ..............

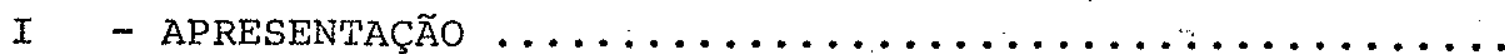

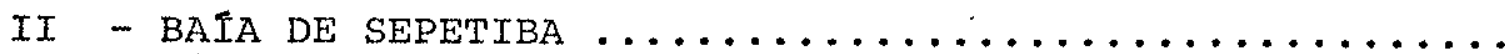

A. Resultados obtidos $\ldots \ldots \ldots \ldots \ldots \ldots \ldots \ldots \ldots \ldots$

III - BAIA DE ARATU E ENSEADA DOS TAINHEIROS ......... 62

A. Aspectos da Ocupação das Areas de Interesse ........

B. Características da Sedimentação Atual na Baía de To

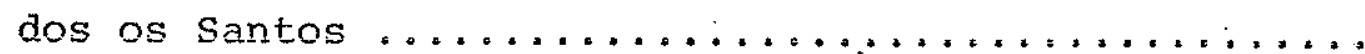

C. Características da sedimentação Atual na Enseada dos Tainheiros

D. Características. da Sedimentação Atual na Baía de Ara-

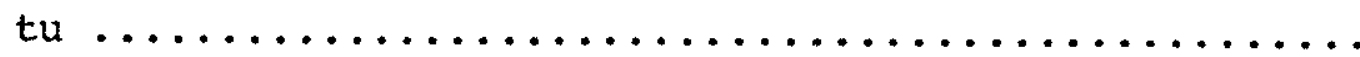

CAPITULO V - PORTOS EM ESTUARIOS: OS CASOS DO POTENGI, ESTA DO DO RIO GRANDE DO NORTE; DE SANTOS, ESTADO DE SÃO PAULO; E DE ITAJAI-AÇU, ESTADO DE SANTA CATARINA ....

I. - APRESENTAÇÃO

II $\quad$ ESTUARIO DO POTENGI $\ldots \ldots \ldots \ldots \ldots \ldots \ldots \ldots \ldots \ldots \ldots$

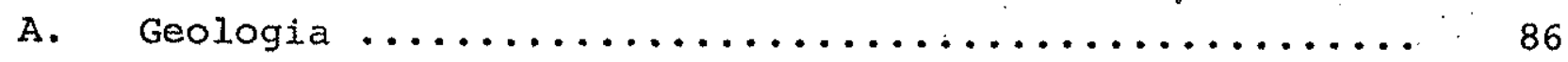

1. Grupo Barreiras ..................... 86

2. Sedimentos Quaternärios .................. 88

3. Recifes ............................. 89

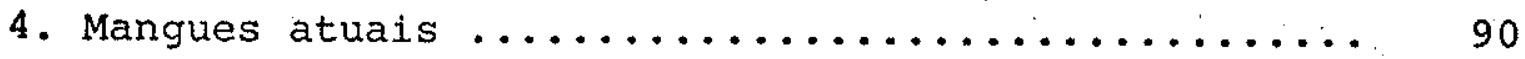

5. Praias e dunas ........................... 91

B. Geomorfologia ......................... 92 
Pāg.

1. Compartimentação geomorfológica da ärea .......... 92

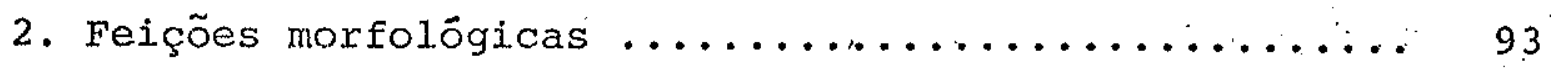

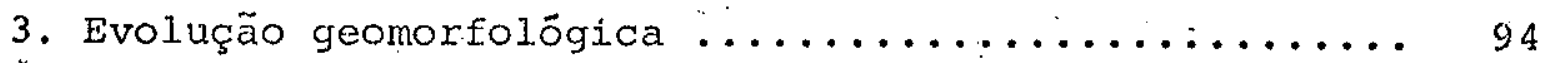

C. Variações Batimêtricas ...................... 95

1. Morfologia atual $\ldots \ldots \ldots \ldots \ldots \ldots \ldots \ldots \ldots \ldots . \ldots \ldots$

2. Comparação de cartas batimétricas $\ldots \ldots \ldots \ldots \ldots \ldots . . . . .68$

D. Caracteristicas da Coluna sedimentar Rasa da Foz do Po

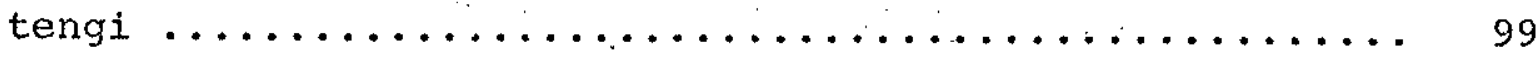

E. Características dos Sedimentos de Superficie de Fundo . 107

1. Composição granulométrica ................. 107

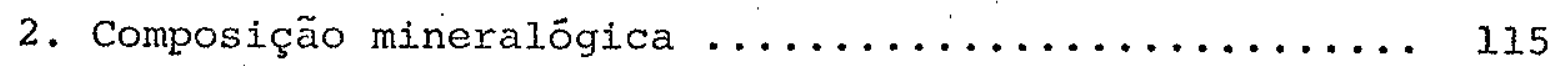

F. Sintese da Dinâmica Sedimentar Atual............ 118

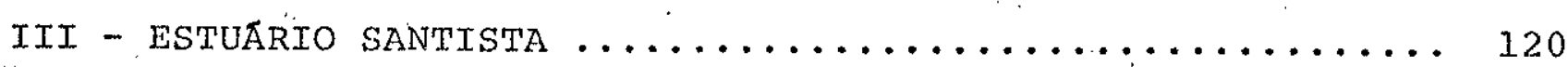

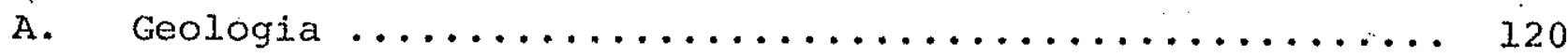

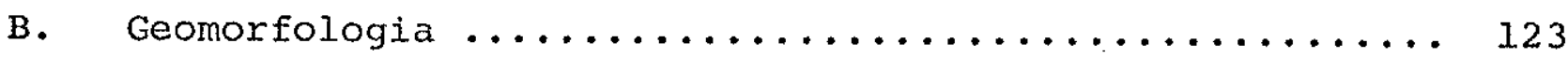

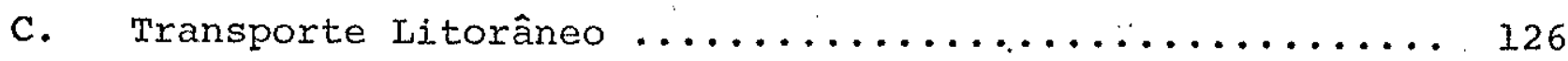

D. Características dos Sedimentos de Superfície de Fundo.. 126

1. Composição granulomētrica $\ldots \ldots \ldots \ldots \ldots \ldots \ldots \ldots \ldots$

2. Composição mineralögica .................. 134

3. Variaçōes temporais das făcies sedimentares de super

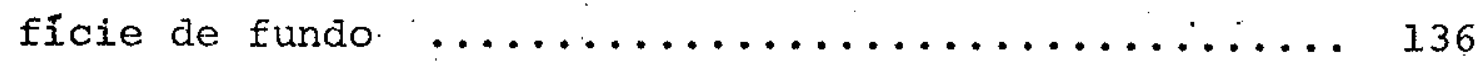

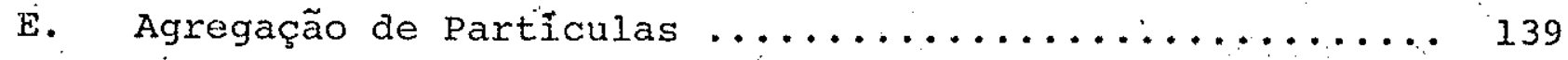

F. Salinidade e Material em Suspensão ............. 151

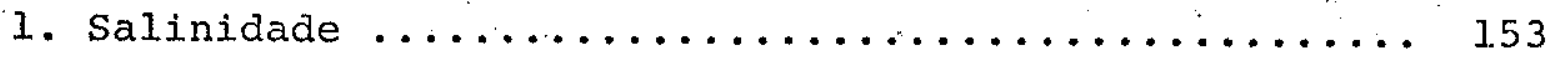

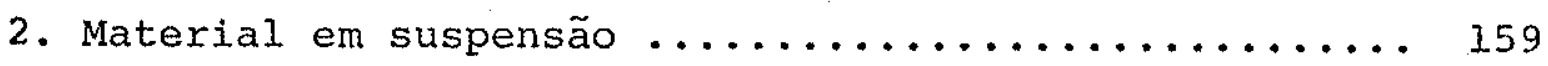

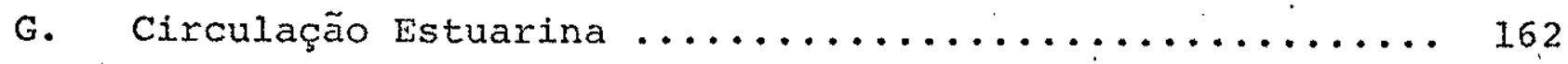

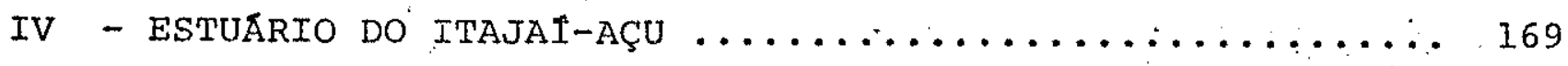

A. Características Gerais da Circulação Regional de sedi

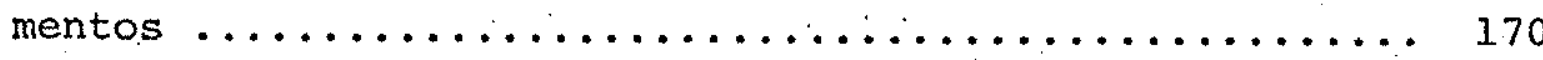


B. Vazão pluvial. e.nostragem.

B. Vazão Fluvial e Amostragem ................ 176

C. Variações Recentes da Morfologia do Fundo do Eștuã-

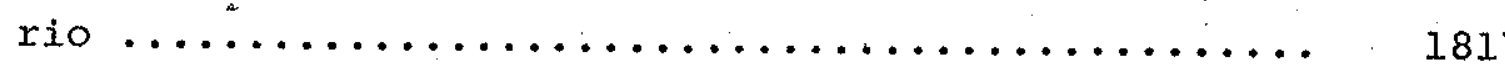

D. Características dos Sedimentos de Superfúcie de Fun do

1. Resultados obtidos na campanha de $1982 \ldots \ldots$...

a) Observações realizadas durante a amostragem .

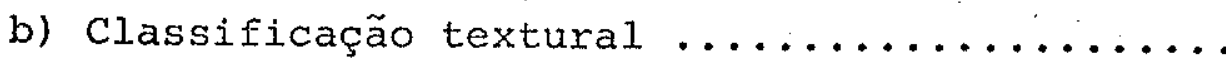

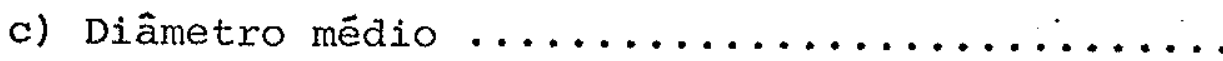

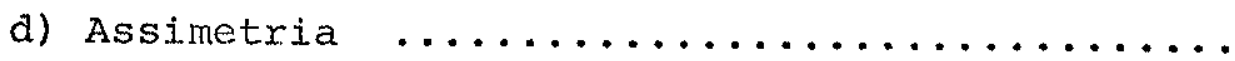

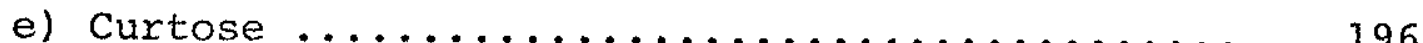

f) Distribuição das porcentagens de areia ..... 198

g) Análise de minerais pesados ............ 201

2. Resultados obtidos na campanhá de $1983 \ldots \ldots . .219^{\prime}$

a) Observações realizadas duxante a amostragem . 219

b) Classificação textural .............. 219

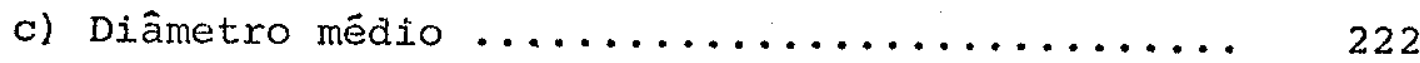

d) Distribuição das porcentagens de areia ..... 222

3. Variações temporais das fäcies de superfície de

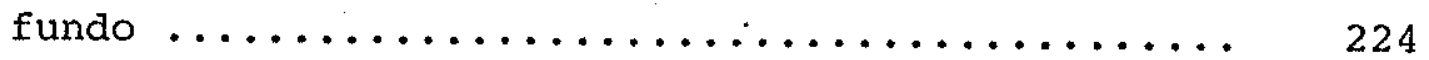

E. Salinidade e Material em suspensão............ 229

1. Salinidade .......................... 229

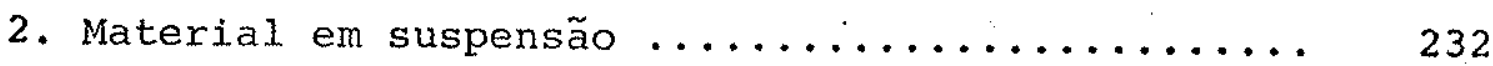

3. Correlação entre salinidades e teores de material em suspensão

F. Circulação Estuarina $\ldots \ldots \ldots \ldots \ldots \ldots \ldots \ldots \ldots . \ldots \ldots \ldots \ldots$

CAPITULO VI - DISCUSSÃO DOS RESULTADOS $\ldots \ldots \ldots \ldots \ldots \ldots .246$

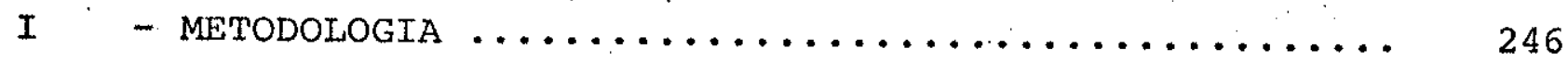

A. Plantas e Imagens de Sensores ............... 247

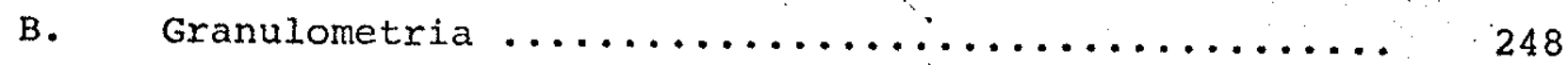

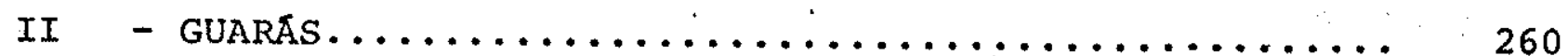


IV - OS ESTUARTOS

V - ASSOREAMENTO 
CAPITULO I

\section{INTRODUÇÃO}

Segundo QUINN (1972) pode-se distinguir duas épocas de gran de desenvolvimento portuário. A primeira delas, seria relacionada ao Império Romano, caracterizada por estruturas monumentais, de tecnologia bastante evoluida, que só não teriam subsistido por falta de conservação ou acidentes naturais; algumas técnicas en tão empregadas perderam-se durante séculos, tendo sido recuperadas e usadas em portos modernos.

Foi no século XIX que ressurgiu o interesse pela instalação de portos, acompanhando a expansão do Império Britânico e de suas colônias; destas surgiram os Estados unidos, que na atualidade é a nação de maior desenvolvimento portuārio, abrangendo portos na costa do Pacífico, do Atlântico, do Golfo do México, alēm dos Grandes Lagos, atingidos pela Hidrovia Saint Lawrence.

os portos brasileiros mais importantes desenvolveram-se acom panhando esse movimento histórico do sēculo XIX, possivelmente a partir da fuga da corte portuguesa, subsequente elevação do pais a Reino Unido e abertura dos portos em 1808 .

No século $\mathrm{xX}$, o aumento crescente do comércio internacional (FIGURA 1) exigiu melhoria e diversificação das funções portuá rias, que passaram a abrigar numero e tipos de navios de dimensões crescente mente incompativeis com as caracteristicas naturais de abrigo e canais naturais (FIGURA 2). Para GEORGE (1967, p.318) "todos os portos modernos são, em escala variāvel portos artificiais, desen volvidos a partir de um sitio natural insuficiente para atender às necessidades da navegação atual".

Observações de cunho geológico sempre constaram, embora fre qủentemente de modo esparso e não sistemático, dos levantamentos referentes a sitios portuários. Dizem respeito à constituição dos fundos submersos (que podem favorecer ou não a ancoragem), à dis tribuição de pontões rochosos, baixios, canais e outras feições de interesse à navegação, integrando os chamados levantamentos hi drográficos. Estes, segundo QUINN (1972, p.115) são realizados "para determinar as elevações do fundo do corpo d'ägua e deveriam se estender a uma área algo maior que os propostos canal e porto. 
Adicionalmente, deveriam localizar as linhas de costa de preamar e baixamar e todas as estruturas ou obstruções na āgua e ao longo da linha de costa, tais como barcos afundados, recifes ou pedras grandes". Outras investigações, recomendadas por QUINN (1972), e de algum modo ligadas ã geologia, são as de sondagens e análises de solos.

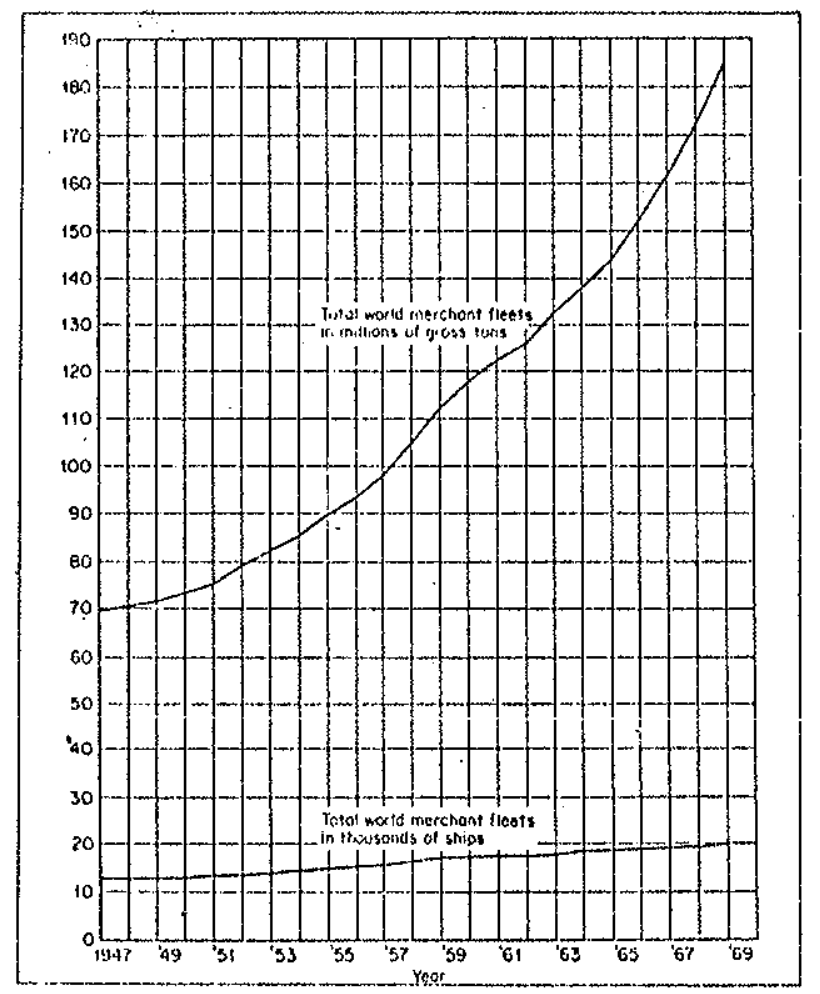

FIGURA 1 - Crescimento da frota mercante mundial entre a Segunda Guerra Mun dial e 1969 (QUINN, 1972, p.5). Curva superior - Frotas mercantes mundiais em mithões de toneladas brutas e curva inferior em milhares de navios.

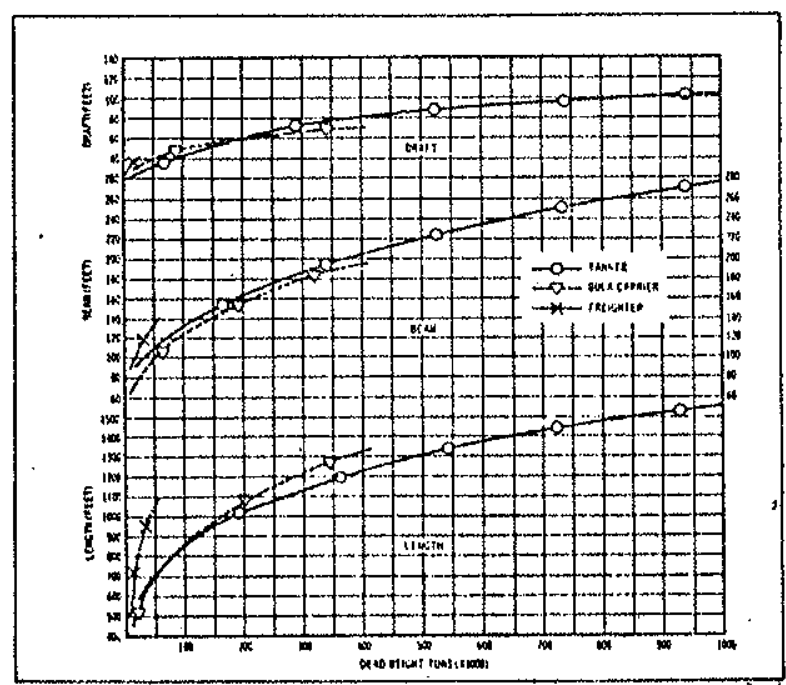

tanques graneleiros carga geral

FIGURA 2 - Características dos maiores navios de carga e frete, projetadas até $O$ ano de 2040, com base nas tendências entre 1937 e 1967 (BRUNN, 1976, p. 21). Do alto para baixo: calado, bôca e cormprimento em pés versus peso total em milhares de toneladas. 
Outros autores que tratam de engenharia de portos, dedicam aos aspectos geológicos um tratamento diferenciado, como è o caso de BRUUN (1976), que dedica dois capitulos de seu trabalho aos problemas de sedimentação e geomorfologia costeiras.para esse au tor (p.68), "o desenvolvimento de estruturas de engenharia portuä ria está intimamente relacionado ao desenvolvimento de aspectos tecnológicos de navegação e transporte como um todo. Maiores cala dos requexem canais de aproximação mais profundos, que não preci sam necessariamente ser protegidos, mas sua localização e geome tria deve ser relacionada a condições reais de regime de ventos, ondas, correntes e sedimentação".

BRUUN (1976) distingue, para os fatores sedimentológicos e geomorfológicos, duas abordagens: uma evolutiva e outra dinâmica. "A primeira é típica de pesquisa descritiva (sic) como geologia e geografia. A segunda pertence ao enfoque físico ou de engenharia no qual todo processo é considerado com relação à forças atuantes" (BRUUN, 1976, p.319). Propõe--se então esse autor a desenvolver os fátores em pauta sob o segunáo ponto-de-vista enunciado, e para tanto busca quantificar ou equacionar os processos de interesse. embora reconheça que fórmulas para quantificar os processos cos teiros raramente sejam universais. Considera fundamental a noção de que os sedimentos movem-se entre dois pólos, source e drain. que constituem a noção bāsica geológica de ārea-fonte e área de deposição. Suas conclusões gerais vão no sentido de que se deve evitar a implantação de portos a juzante de äreas-fontes importan tes, e de que as estruturas implantadas não devem favorecer a de posição de sedimentos em transporte. Essas questões, no que se re fere à sua quantificação, foram amplamente tratadas por SILVESTER (1.974).

Neste trabalho buscar-se-á apresentar os trabalhos brasilei ros de geologia aplicada a portos justamente sob a primeira perspectiva apontada por BRUUN (1976).

Tais estudos visam essencialmente a aspectos sedimentolögicos e geomorfolögicos, e foram iniciados na dēcada de 60 , no es tuāxio santista, no âmbito do Laboratörio de Hiđráulica da EPUSP/ DAEE (EPUSP/DAEE, 1966), seguido de estudo feito para a BRASCON SULT no Canal de são sebastião (KUTNER, 1969). A essa mesma ēpoca diversos outros estudos de sedimentação costeira foram realizados 
no Estado de São Paulo, embora não aplicados a portos, voltados ao estudo de sedimentos de superfície de fundo (KUTNER, 1962,1963; MA GLIOCCA \& KUTNER, 1964, 1965). Todos os trabalhos mencionados da década de 60 foram revistos por KUTNER (1976).

A partir de 1973, estudos de sedimentação costeira aplica dos a portos foram promovidos pelo IPT, por solicitação do Instituto Nacional de Pesquisas Hidroviārias, atual Instituto de Pes quisas Hidroviārias da PORTOBRÁs, em diversos pontos da costa bra sileira (Pará, Rio Grande do Norte, Espírito Santo, Rio de Janei ro, são Paulo), e da Companhia Baiana de Navegação (Bahia). Os re sultados desses trabalhos acham-se expostos em numerosos relató rios do IPT, e foram parcialmente publicados por FULFARO \& PONÇANO (1976), PONÇANO \& FULFARO (1976a), PONÇANO et al. (1976), FULFA RO et al. (1976 e 1978), PONÇANO (1976) e PONÇANO \& FOLFARO (1978). Todas essas investigações inserem-se no campo da Geologia Aplicada, mais especificamente no que internacionalmente se conhe ce por Geologia de Engenharia, sobre cujo desenvolvimento, aborda do por JOHN (1974), CAMARGO (1976) e OLIVEIRA (1981) cabem algu mas considerações.

A geologia aplicada a problemas de engenharia teve seu ini cio, no Brasil, na década de 50, com trabalhos de PICHLER (1954 e 1957) vol tados à implantação de barragens e a estabilidade de encostas. Des sa época, até 1974, configurou-se um grande esforço por parte dos geölogos em aproximar-se da linguagem e métodos pröprios da enge nharia, o que resultou, em alguns casos, num certo abandono da me todologia estritamente geológica. A realização do II Congresso da Associação Internacional de Geologia de Engenharia em São Paulo, em 1974, permitiu amplo intercâmbio entre técnicos nacionais e es trangeiros, que resultou, para alguns grupos de profissionais, em revalorização do conhecimento geológico.

Essa situação se refletiu, em 1976, na organização do temā rio e teor das contribuições e debates do I Congresso Brasileiro de Geologia de Engenharia, realizado no Rio de Janeiro, que con tou com uma sessão dedicada a Geologia Aplicada a Portos e Canais. Nessa ocasião KUTNER (1976) apresentou uma revisão de seus traba lhos anteriores, e o presente autor teve ocasião de apresentar al guns resultados de investigações das quais participou a partir de 
1973. Tivemos, desde então o ensejo de desenvolver diversos ou tros trabalhos na costa brasileira (FIGURA 3), que nos permitiram avançar um pouco mais no conhecimento das questões de geologia a plicada a portos.

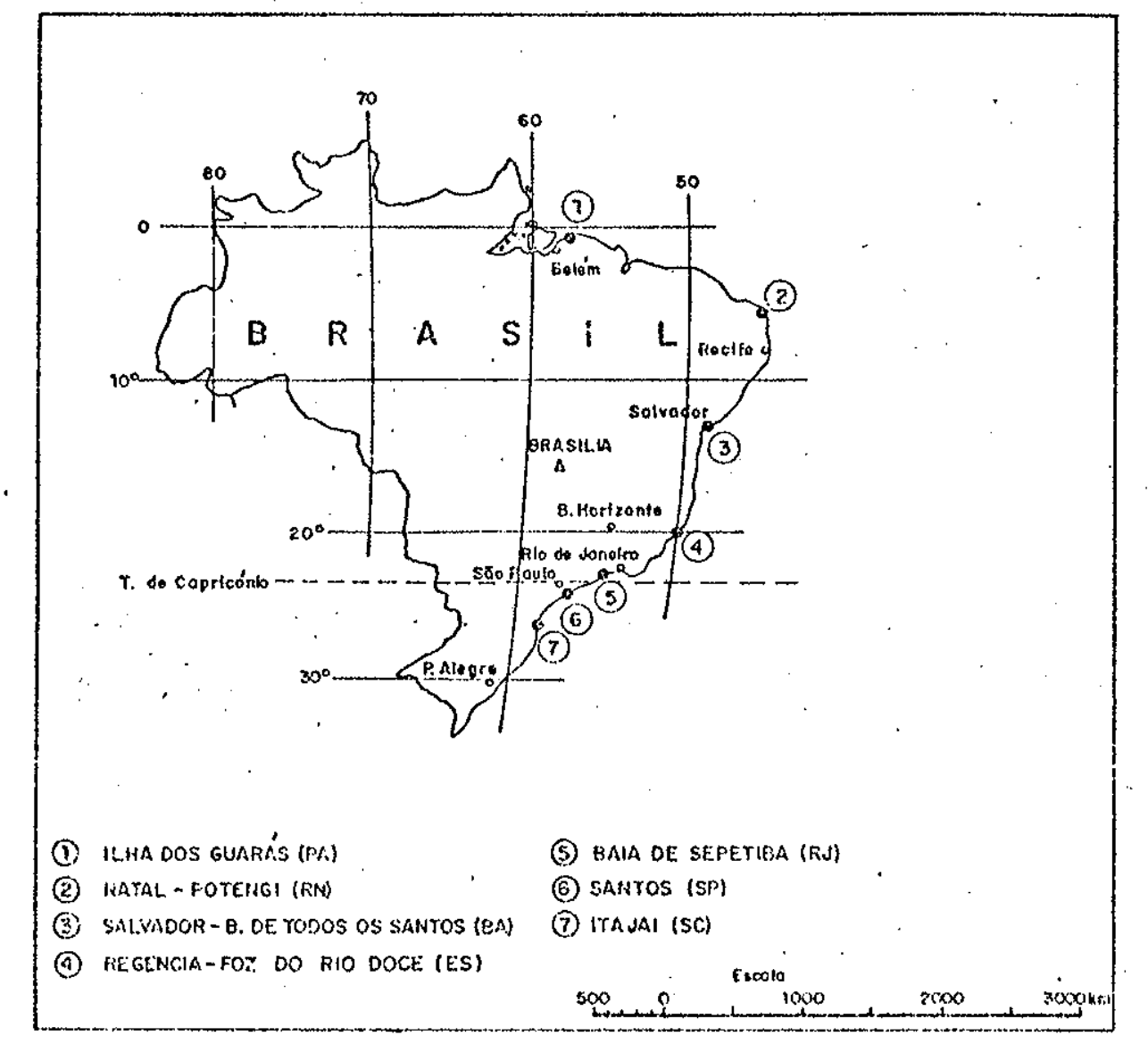

FIGURA 3 - Iocalização das äreas portuărias abordadas neste estudo.

Embora a metodologia usada seja exposta e discutida em capí tulos subsequentes, julgamos oportuno, nesta apresentação, tecer algumas considerações de ordem genérica.

Não nos parece possivel, ao menos em geologia, fazer uma distinção rígida entre a pesquisa bãsica e a aplicada; esta ūlti ma consiste basicamente na mobilização do conhecimento geológico em função de um dado problema. Assim sendo, torna-se necessārio lan çar mão de värias técnicas, e, especialmente, de obter : informa ções fundamentais - que poderiam ser consideradas como pertencentes ao âmbito da ciência básica - para se chegar a uma aplicação satis fatória.

Disso decorre que os trabalhos de geologia aplicada representam, necessariamente, un recorte entre ciēncia básica e soli citações ligadas ao mercado, à produção, ao planejamento. Temos 
então consciência de que as pesquisas ditas aplicadas, como é o. caso desta tese, levam-nos por vezes a ficar na incômoda situação em que vārias linhas de pesquisa podem ser vislumbradas, sem que entretanto se possa desenvolvê-las em maior profundidade.

Consideramos que no caso dos portos os aspectos de aplica ção poderiam ter passado por maior avanço, mormente no que se ré fere à inserção de aspectos de engenharia, caso se dispusesse de maior acervo de conhecimentos básicos referentes à tipologia dos estuários brasileiros. Ficamos porém num estägio tal que a caracterização dinâmica dos corpos d'ägua costeiros teve que ser feita pari passu às solicitações de projeto.

Visando a tornar mais clara a exposição do tema aqui propos to, parece-nos conveniente proceder a uma exposição em sepa rado dos casos estudados (case histories), embora desigualmente desenvolvidos, de sorte que se possa melhor avaliar os avanços e lacunas nos resultados obtidos.

İ OBJETIVOS

Levando em conta as preocupações expressas nos parägrafos an teriores, podemos definir como objetivo principal desta tese a delimitação, dentro dos princípios e métodos de nossa ciência, do conhecimento geolögico necessārio à implementação de portos no Brasil. Respeitados os limites impostos pelo número de sítios es tudados, buscamos chegar à definição de uma metodologia de trabá Iho, e, adicionalmente, fornecer informações básicas a respeito do comportamento de alguns setores da costa brasileira, até o momento pouco conhecidos. 
CAPITULO II

\section{METODOLOGIA}

\section{PRINCIPTOS GERAIS}

As feições costeiras em que se situam os sitios portüärios podem ser considerados marginais e internas às plataformas conti nentais, a cuja gênese portanto se ligam.

Há uma concoraância geral da literatura em considerar a plataforma continental como produto das variações de nível mari nho quaternárias (cf.EMERY, 1967; FLINT, 1971). As causas dessas variações podem ser de diversas ordens, locais ou regionais (movi mentos crustais tectônicos e isostāticos, compactação de sedimen tos) e eustáticos (movimentos tectônicos e isostáticos de crosta oceânica, sedimentação marinha, vulcanismo submarino, adição de āgua juvenil nos oceanos, mudanças térmicas das águas oceânicas , yariações dos volumes d'ägua relativos marinhos e continentais, transferência de águas de mares rasos para oceanos) (FLINT, 1971, p.316). Dessas causas, admite-se que o glācio-eustatismo seja a mais importante, permanecendo porém em aberto a questão de seu peso face a fatores tectônicos. Ainda segundo FLINT (1971, p.317), a teoria do controle glacial do nível marinho foi proposta em 1841 por MACLAREN, e raramente foi colocada em dúvida.

Há numerosos trabalhos que buscam reconstituir as oscilações quaternārias de nïvel marinho, que geralmente resultam na constru彑 ção de curvas de oscilação, locais, regionais, ou mundiais, das quais um exemplo representativo pode ser referido a FAIRBRIDGE (1966).

As amplitudes dessas oscilações têm șido déduzidas por cri térios múltiplos, entre eles: estimativas de volume de cobertü ras de geleiras continentais, distribuição altimëtrica de feições marinhas emersas, distribuição altimētrica de feições continentais submersas. Feições reliquiares, tais como depósitos sedimentares, suas estruturas e conteúdo fóssil; tèm sido analisados, e suas evidências, datadas de modo relativo ou absoluto, neste caso atra vës dos mëtodos $\mathrm{C}_{14}$ e Th/U (EMERY, 1967; FIINT, 1971).

Ao restringir o significado da evolução da plataforma conti 
nental a estuārios e lagunas, observa EMERY (1967, p.9) que " a distribuição regional de estuärios e lagunas corresponde às carac teristicas regicnais das plataformas continentais e seus prolonga mentos - as planicies costeiras. Em outras palavras, as lagunas são tipicas de regiões de plataformas continentais e planícies cos teiras amplas e muito pouco inclinadas. Pequenos estuários ocor rem onde plataformas e planícies costeiras são estreitas e pos suem relevos acentuados".

Ainda EMERY (1967) admite ter havido um periodo de elevação pós-glacial do nivel marinho cuja grandeza seria compativel com a média mundial de profundidade das plataformas continentais (130 m). Durante essa elevação pós-glacial ter-se-iam formado inicialmente à borda do talude continental lagunas; com o progresso da eleva ção, lagunas e estuários teriam caracterizado a seção intermeđia ä ria da plataforma, situação que foi se modificando em favor de uma dominância de estuärios na fase māxima do pós-glacial. Esse quadro genérico seria afetado principalmente pela velocidade rela tiva (ou seja, caracteristica de cada região) de subida do nivel marinho, fator que regularia a maior ou menor eficiência das fon tes detriticas continentais em colmatar os estuārios e lagunas . Esta noção, aliās, é clāssica em geologia (tectônica x sedimentä ção), conforme entre outros, KRUMBEIN \& SLOSS (1963).

Embora genērico, o referido trabalho de EMERY tem a felici. dade de destacar o carāter transitório dos estuários, em termos geolögicos, pois que representariam apenas 1 용 da história da plataforma continental. RUSSEL (1967) discorre no mesmo sentido, e, embora acredite que o pös-glacial tenha se dado nos ültimos 500.00 anos, e não nos ültimos 18000 anos,como se considera hoje quase unanimemente, aceita que o estudo dos estuārios è, hoje em dia, muito oportuno, pois estudos de casos atuais poderão ter va lor histórico em poucas dēcadas.

Essa transitoriedade confere ao estudo dos corpos d'água cos teiros, que oferecem melhores condições de abrigos a portos, sua peculiaridade mais marcante, jä que suas condições naturais podem sofrer alterações apreciāveis em tempos histōricos.

o reconhecimento dos diversos aspectos da plataforma conti nental brasileira tem seu marco mais importante na realização do Programa de Reconhecimento Global da Margem Continental Brasilei 
ra - Projeto REMAC, iniciado em 1972, abrangendo toda amargem con tinental brasileira, bem como äreas oceânicas e continentais adja centes do Atlântico Equatorial e Atlântico Sudoeste (CHAVEs, 1983). Dentre os numerosos estudos realizados, têm maior interesse para nosso trabalho aqueles referentes à morfologia e sedimentologia', por conterem dados de interesse às oscilações do nível marinho no Quaternārio, os quạis, em última instância, são os responsāveis pe la constituição dos corpos d'água costeiros, estuários, lagunas e baías (em que pese, neste último caso, componentes tectônicas da maior relevância). A caracterização geomorfolögica da margem con tinental brasileira (ZEMBRUSCKI et alii, 1972) levou à distinção de três regiões principais: Norte, Leste-Nordeste e Sul. A primei ra abrange plataforma de até $300 \mathrm{~km}$ de extensão (foz do Amazonas) é ruptura para o talude entre 80 e 130-140 m de profundidade. A Leste-Nordeste tem plataforma estreita, em torno de $20 \mathrm{~km}$, e pro fundidades de 40-50 m. Na Sul, a plataforma tem em média $150 \mathrm{~km} e$ sua borda é mais profunda que nos casos anteriores, variando de 160 a $190 \mathrm{~m}$. Estes dados, comparados com os da literatura interna cional previamente mencionados, indicam influêncjas tectônicas de carāter. regional, afetando a profundidade da borda da plataforma. Um panorama da distribuição dos sedimentos de superfície de fun do, através de 800 amostras, é fornecido por MJIJIMAN et alii (1972).

Uma revisão referente às oscilações do nivel marinho foi apresentada por KOWSMANN \& CosTA (1979), que detectaram, atravēs de evidências ambientais, morfológicas e datações $C-14$ seis ní veis persistentes ao longo da costa brasileira, correspondentes a proximadamente às isóbatas de $130,110,90,75,60$ e $40 \mathrm{~m}$. O ní vel de $-130 \mathrm{~m}$ é atribuido ao ültimo evento glacial, em torno de 15000 B.P.; datações C-14 situariam o nivel - $110 \mathrm{~m}$ entre 13 e 14000 B.P.. Idades de 12000 B.P. e 11000 B.P. são inferidas pa ra os niveis $-90 \mathrm{~m}$ e $-75 \mathrm{~m}$. O nivel de $-60 \mathrm{~m}$ teria idade de 11000 B.P., por C-14, enquanto que se infere para o nível $-40 \mathrm{~m}$ 9000 B.P.. As inferências foram feitas com base em curva de va riação eustática construída para os ültimos 35000 anos.

As variações holocênicas do nível marinho têm sido determi nadas para a costa paulista por SUGUIO e MARTIN, em diversos tra balhos, sintetizados por MARTIN, et alii (1979a), e para a costa baiana (BITTENCOURT et $a$ lii, 1979b; MARTIN, et alii,1979b), atravēs 
de amplos programas de datação C-14. As curvas de oscillação do ní vel marinho apresentam certà diversidade, mas indicam um $\therefore$ māximo transgressivo de uns $5 \mathrm{~m}$ em torno de 5000 B.P., e um nivel em torno dos $3 \mathrm{~m}$ há cerca de 2500 - 3500 B.P..

Em linhas gerais, pode-se concluir que os eventos mais im portantes na formação dos corpos d'ägua costeiros, quais sejam , - último entalhe e a subsequente transgressão, podem ser referidos a eventos globais, o primeiro referido ao māximo da glaciação Whrm ou late Wisconsin, e o segundo ao Flandriano, conforme tive mos a ocasião de sugerir para o caso da baía de sepetiba (PonçANo, 1976a; PONÇANO et alii,1979, atravēs de anälise geomorfológica.

Aqui se estabelece a ligação entre os fenômenos de ordem ge ral, que afetaram a plataforma continental, e as feições menores de sua margem interna, que são as feições costeiras, pois a dis tribuição dos principais canais de acesso e circulação, bem como "a dinâmica dos processos sedimentares atuais necessita ser colo cada no contexto da evolução quaternāria da ārea de estudo, para que se possa esclarecer a importancia efetiva do balanço erosão/cie posição, possibilitando então que sejam feitos prognósticos sobre seu comportamento. Isto pode ser feito por meio de uma análise geo morfolögica centrada na evolução de determinadas formas que cons tituixão o arcabouço da sedimentação atual" (PONÇANo, 1976a, p:13).

Levamos então em conta que "a distribuição e características da pelicula sedimentar que reveste os ambientes subaquāticos das adjacências de um porto representam uma resultante de todos os fa tores determinantes da sedimentação, constituindo-se então seu es tudo qualitativo e quantitativo uma primeira aproximação ao esta belecimento de critérios geolögicos destinados ã escolha de lo cais e de tēcnicas construtivas mais viāveis à instalação de um conjunto portuārio" (PONÇANo, 1976a, p.2). KƯJ'NER (.1976) veio a ex pressar opinião semelhante.

Dessa forma, a orientação seguida nas investigações aqui pro postas leva ao desenvolvimento de estudos em três etapas princi-
pais:

- estabelecimento de um modelo da evolução geomorfológica da área considerada;

- caracterização da textura dos sedimentos de superficie de fundo, por meio de seus parâmetros representativos e de sua composição 
mineralögica, visando a compreensão e estabelecimento de sua dí. nâmica, caracterização de sedimentos em suspensão;

- integração de elementos geomorfológicos, batimétricos, sedimentológicos, é sintese geral a respeito da área sob o ponto-de-vis ta da viabilidade de implantação de um porto, ou da intervenção em obras jã realizadas.

\section{MATERIAIS E METODOS}

A. Plantas e imagens de sensores remotos

o planejamento e realização dos trabalhos nas äreas aqui apresentadas sempre se iniciaram pela coleta e anälise das cartas topogräficas e nāuticas, e fotos aēreas disponíveis. Eventualmente foram utilizadas imagens LANDSAT para determinação de direções de dispersão de sōlidos em suspensão. Discriminação e discussão a respeito dos materiais e tēcnicas empregadas serão feitas, sempre que necessārio, no decorrer da exposição dos próximos capítuios.

B. Amostragem

A coleta de amostras em āguas estuarinas foi feita com uti lização de baxco especialmente adaptado para esta finalidade, dé fundo.chato, em aluminio, equipado com guincho e roldanas, de $7,5 \mathrm{~m}$ de comprimento, equipado com motor de $50 \mathrm{HP}$. No ać. de. baías e de mar aberto, foram usados barcos maiores, do tipo cama roneiro, com as adaptações necessárias.

As estações de amostragem, previamente estabelecidas, eram atingidas por aproximação visual, com auxílio de telêmetro e sex tante, no caso de estuārios em que havia grande número de feições topogräficas (inclusive urbanas) de referência. Em mar aberto e baías as estações de amostragem foram atingidas por aproximação sucessiva por mejo de sextante, através da referência de pontos notāveis assinalados nas cartas náuticas.

Os sedimentos de superfície de fundo foram coletados com amostradores de mandíbula, do tipo Van Veen, recorrendo-se, em al guns casos, a amostragem por cravação çom testemunhador do tipo piston corer.

Amostras de ãgua para análise de material em suspensão e sa 
Iinidade foram coletadas com garrafas de Van Door com $3^{\prime} l$ de capaci dade.

\section{Anālises Granulomëtricas}

As análises granulomëtricas dos sedimentos de superfície de fundo foram processadas de acordo com o procedimento rotinejro dos laboratórios de sedimentologia do Instituto de Geociências da USP e do IPI. A fração areia foi separada em classes de $1 / 2 \varnothing$ enquanto que a separação de siltes e argilas se deu em intervalos de $1 \varnothing$. Os parâmetros estatísticos granulométricos foram calculados segundo as fórmulas de FOLK \&. WARD (1957), as escalas :qualitati vas dos graus de seleção, assimetria e curtose são tambëm as des ses autores, segundo a tradução proposta por suguIo (1973). Uma classificação textural segundo o diagrama triangular de SHEPARD (1954, apud suguIo, 1973) também é oferecida. As classes granulomé tricas são referidas à escala de Wentworth.

A descrição das caracteristicas granulométricas com base nas fórmulas de FOLK \& WARD (1957) e segundo os intervalos de classes texturais merece algumas considerações. Assim, sabe-se que as caracteristicas texturais de um sedimento podem ser referidas a um conjunto de parâmetros estatisticos descritivos de sua dis tribuição granulomētrica, indicativos de tendências centrais ( me diana, mëdia e desvio-padrão) ou caudais (assimetria e curtose).

Os parâmetros propostos por FOLK \& WARD (1957) foram criados a partir dos de INMAN (1952). Esses autores realizaram um es tudo sedimentológico num depósito fluvial fortemente bimodal. (areia e cascalho), característica que os levou a considerar ina dequadas as medidas de INMAN (1952) por se basearem em apenas 2 ou 3 pontos da curva acumulativa, sendo pois insuficientes para descrever curvas não normais.

Para FOIK \& WARD (1957) a mediana deveria ser abandonada,por induzir a erros na apreciação dos sedimentos. Assim, seriam iguais os valores das medianas de um sedimento com $40 \%$ de cascalho e $60 \&$ de areia fina, e outro com $60 \%$ de areia fina e $40 \%$ de argi la. As alterações dos demais parâmetros podem ser vistas na FIGU RA 4 . 


\begin{tabular}{|c|c|c|c|c|}
\hline & DIAMETRO MEDTO & DESVIO-PADRÃO & ASSIMETRIA & . " curtose \\
\hline INMAN & $\frac{916+984}{2}$ & $\frac{\not 84-\emptyset 1.6}{2}$ & $\frac{\not 84+\not 16-2050}{\not 84-\not 16}=\frac{\not 95+\not 15-2050}{\not 84-\not 16}$ & $\frac{1 / 2(614-\not 95)-1 / 2(695-\not 884)}{\not 84-\not 16}$ \\
\hline $\begin{array}{l}\text { FOLK \& WARD } \\
\text { (1957) }\end{array}$ & $\frac{\not 16+\not 550+\not 884}{3}$ & $\frac{884-\not 16}{4}+\frac{895-\not 65}{6,6}$ & $\frac{\not 16+\not 684-2050}{2(\not 84-\not 16)}+\frac{95+\not 695-2050}{2(\not 995-\not 05)}$ & $\frac{\not 95-\not 5}{2,44(975-\not 25)}$ \\
\hline
\end{tabular}

FIGURA 4 - Parâmetros estatísticos segundo INMAN (1952) e FOLK \& WARD(1957).

Em decorrência das alterações propostas, o desvio-pađrão, in dicativo do grau de seleção do sedimento, deixou de ser uma. medi da de tendência central, conforme se constata na exposição que so bre o assunto faz SUGUIO (1973). No caso da assimetria, a combina ção de valores de centro e das caudas leva a uma medida geometri camente independente da seleção.

Para FOLK \& WARD (1957) assimetria e curtose seriam fundamentais para se detectar bimodalidade onde essa, característica não aparece claramente. Mostraram, ađemais, haver relações bem definidas entre os quatro parämetros, equacionados na FIGURA 5.

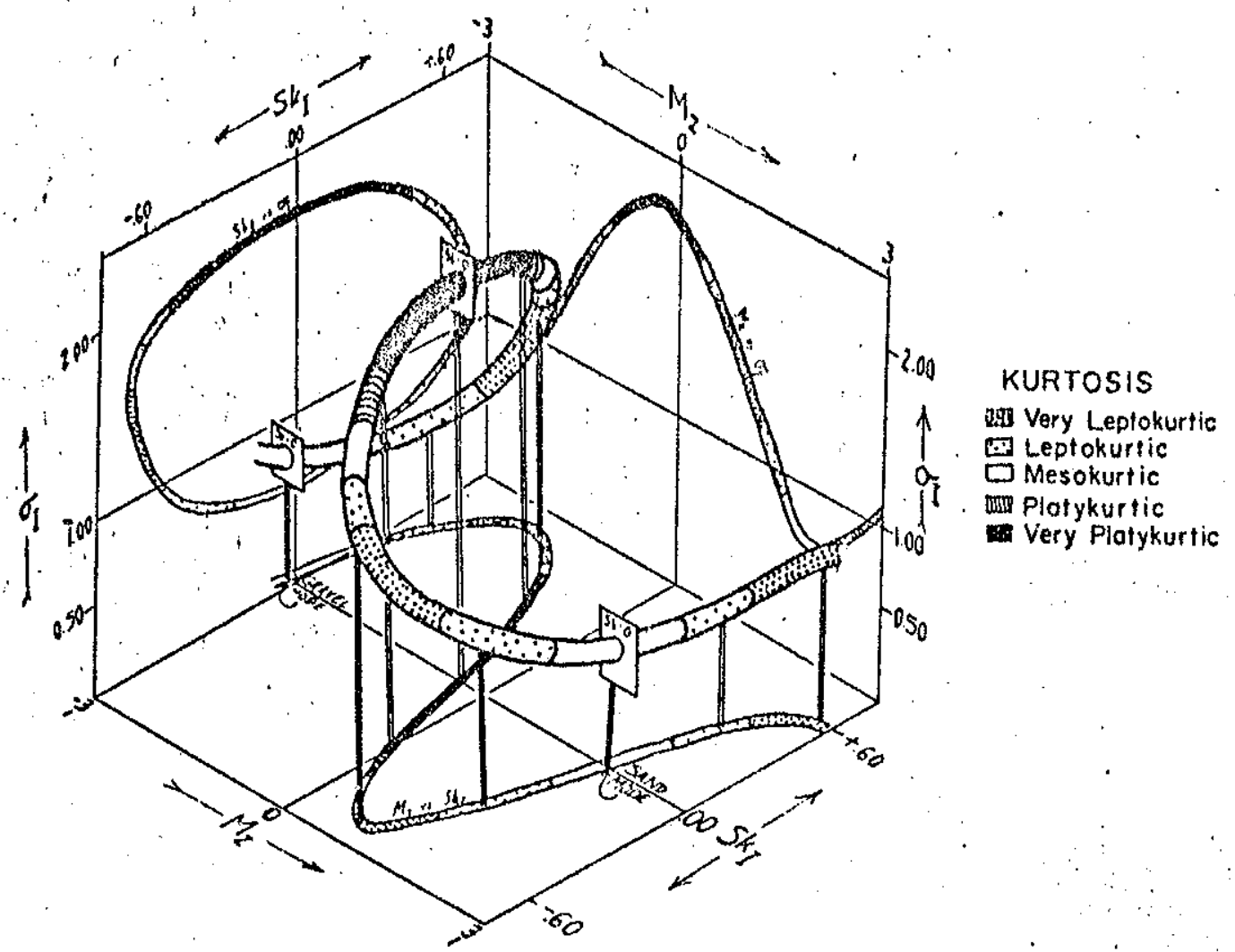

FIGURA 5 - Gráfíco a quatro variáveis, mostrando a relação entre diânetrom -médio (M) desvio-padrão $\left(\sigma_{1}\right)$, assimetria $\left(\mathrm{Sk}_{1}\right)$ e curtose. Reproduzido de FOLK \& WARD (1957,p.23I. 
Paxa SWAN et alii (1978) há duas diferenças entre a estatís tica convencional e a aplicada em sedimentologia. A primeira vem de que ao se agrupar os dados por classe de peso, as partículas discretas deixam de ser consideradas, e os resultados referentes à população de pesos não são iguais aos da população de particulas. Outra diferença é que as medições são feitas atravēs de uma variā vel transformada $(\varnothing)$ e não do diâmetro real.

A fim de superar o primeiro desses dois pontos, geraram amos tras hipotéticas com dados para cada partícula, segundo distribui ções normais padronizadas (média $=0$; desvio-padrão $=1$ ). Com es sas amostras realizaram uma reavaliação do métódo de Fol.K \&. WARD (1957). Para tanto, procederam a correlações entre medidas segundo FOLK \& WARD (1957) e 1) parâmetros para frequência numérica não agrupada (FIGURA 6); 2) parâmetros para frequência não agrupada em peso (FIGURA 7).

Pela FIGURA 6 pode-se concluir que os dois conjuntos de dados descrevem diferentes caracteristicas das amostras. As rela çốs aa IITURA 7, por outro lado, sertam semelhantes às jā determinadas por outros autores entre método dos momentos e método grá fico, o que sugere que as medidas de momento para frequência agru pada em peso se constituem em boas estimativas dos parâmetros não agrupados correspondentes.

Concluem que as medidas gräficas são boas para o diâmetro médio (exceto em amostras muito assimétricas ou com caudas pronun ciadas aquêm de $\varnothing 16$ e alēm de $\varnothing 84$ ) e desvio-padrão (com ressalvas para amostras medianamente selecionadas com caudas significativas nos 5 \% mais finos ou mais grossos ). No caso da curtose e da as simetria, consideram que não se chegou a relações definidas entre os diferentes cálculos porque as medidas não agrupadas são sensi veis às caudas, diversamente das medidas gräficas.

Apontam ainda que as medidas gräficas não são muito sensi veis a populações significativamente não-normais. Se se pretende usá-las, o peneiramento pode ser feito com intervalos de $1 \varnothing$, pois a diminuição do intervalo não aumenta o alcance do método.

SWAN et alii (1979) fazem uma avaliação do método dos momentos para valores agrupados, concluindo que descreve melhor as po pulações que o método de FOLK \& WARD (1957); a diferença entre os 
dois mëtodos seria maior no caso da assimetria e da curtose de curvas significativamente não normais.
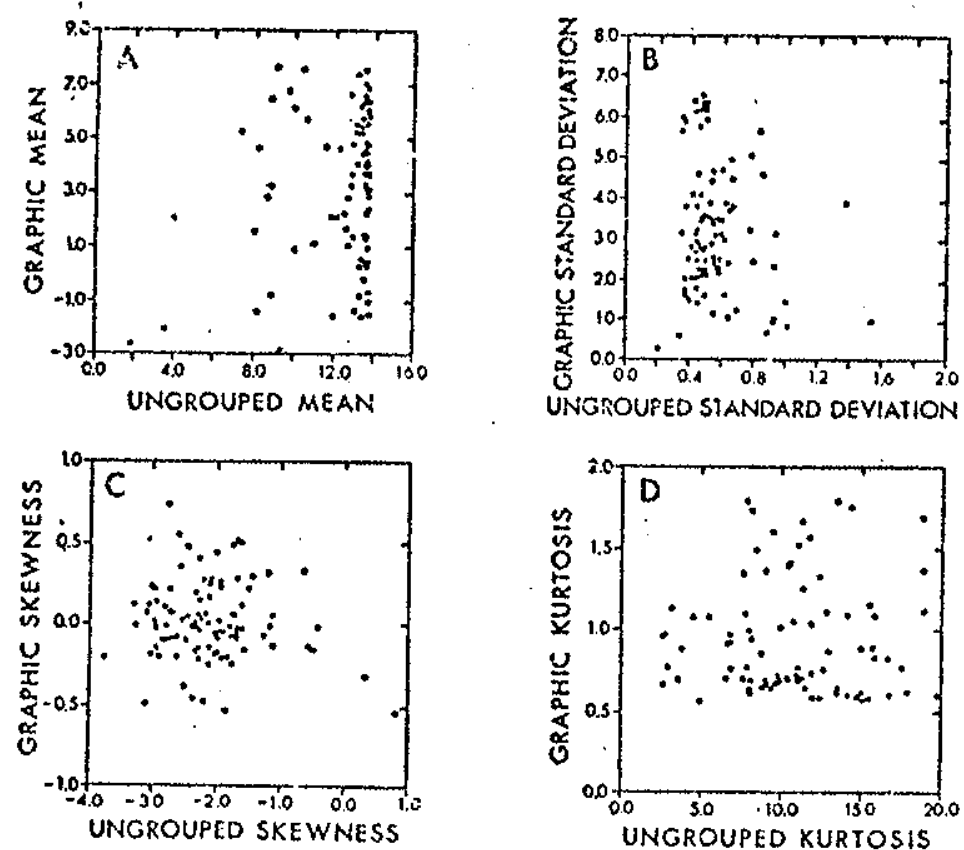

FIGURA 6 - Relações entre as medidas gräficas de FOLK \& WARD (1957) e parâme tros de frequência numérica não agrupada para 100 amostras hipotéticas. Reprō duzido de SWAN et alii (1978, p.873).

No caso do método dos momentos mostram que a precisão dos parâmetros au mentam com a diminuição do intervalo de peneixamento de $1 \not$ para $0,25 \varnothing$. Alëm dis so, o truncamento da curva em 12ø. não alteraria significativamen te os resultados, contrariamente ao truncamento em $9 \varnothing$.

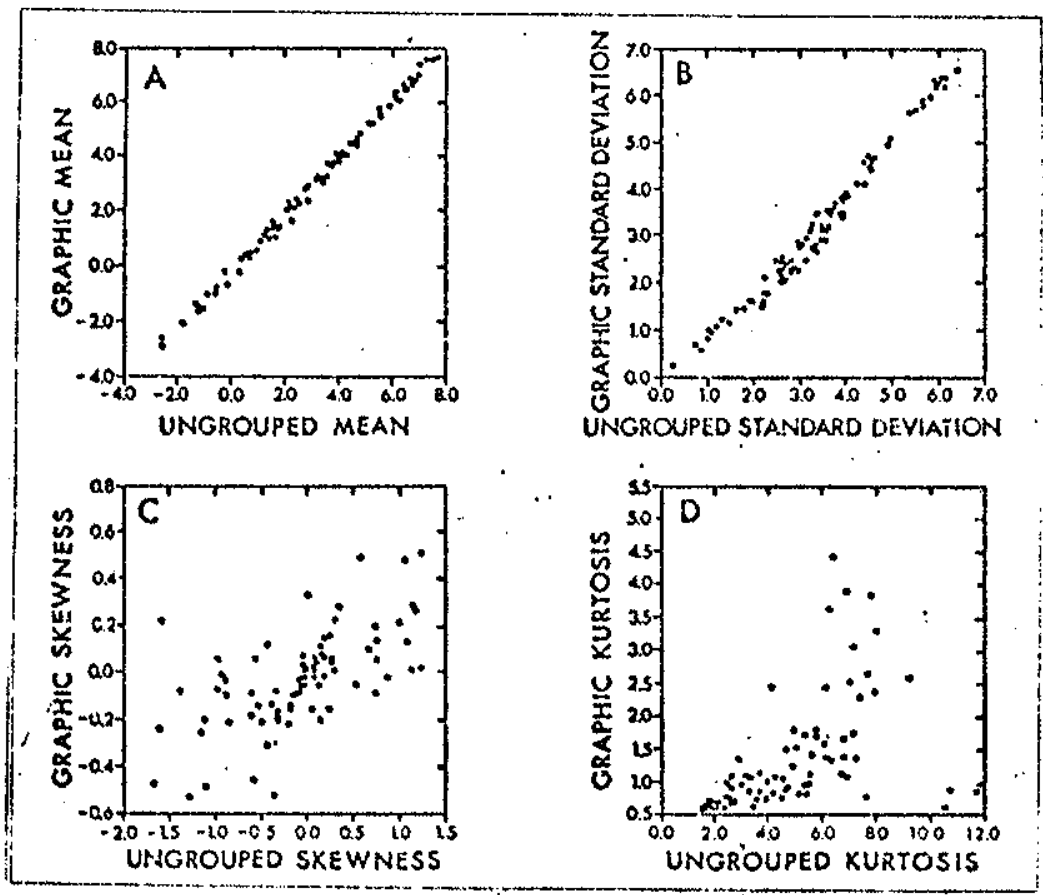

FIGURA 7 - Relações entre as medidas gräficas de FOLK \& WARD (1957) e os pa râmetros de frequểncia por peso não agrupado para 100 amostras hipotëticas. Reproduzido de SWAN et aliz (1978, p.874). 
Levando-se em conta os métođos de laboratóxio empregados nas anālises granulomētricas percebe-se que, embora o mëtodo dos momentos forneça melhores descritores das distribuições granulom métricas, torna-se mais conveniente a utilização das förmulas de FOLK \& WARD (1957), por serem estas mais compativeis com as clas ses granulométricas obtidas nos processos de peneiramento e pipe tagem.

No caso dos sedimentos em suspensão, o procedimento foi ou tro. A literatura indica que, dos métodos disponiveis para a de terminação de classes granulométricas de pequenas quantidades de sedimentos finos, o mais eficiente è oferecido pelos aparelhos do tipo Coulter Counter (SWIFT et alii, 1972; WALKER et alii, 1974).

Segundo SWIFT et alii (1972) o Coulter Counter teria sido desenvolvido no final da dēcada de 50, para contagem de cëlulas sanguineas, sendo a seguir experimentado com sucesso em sedimento logia. Seu princípio bäsico è de que, num eletrólito de campo elé trico definido, a passagem de uma particula provoca alteraçōes de tcctáveis, desde que suas propriedades eletricas sejam diferentes das do eletrólito. Na prätica, a zona eletricamente sensível é bloqueada por um orificio de material condutor, calibrado. $\bar{A}$ medi. da que passam as partículas, mudanças nas propriedades eletroliticas são medidas como pulsações de voltagem. o limite mínimo de concentração do material em suspensão pode ser de 0,2p.p.m. (SWIFT et $a$ i i, 1972 ) ou 1 p.p.m. (WALKER et alii, 1974). Ensaio de re produtibilidade realizado com soluções diluídas de solos indică ram que os resultados obtidos com o Coulter counter são compati veis com os de pipetagem, com desviompadrão de $\pm 6 \%$ da média.

Neste trabalho, para a determinação do teor total de sedi mentos em.suspensão, adotou-se o seguinte procedimento: cada amos tra foi inicialmente agitada, para homogeneização, durante três minutos cronometrados. Imediatamente apōs a homogeneização trans feria-se 1 l para proveta previamente aferida. Em seguida, a amos tra $(1 \ell)$ era passada gradativamente atravës do conjunto filtran te (descrito mais adiante), com auxilio de baqueta. Ao final da filtragem as paredes da proveta eram lavadas com $20 \mathrm{ml}$ de aagua deionizada.

A quantidade de 1 l é aceita como satisfatörià à obtenção do material necessārio para estudo de sólidos em suspensão em 
águas de estuários (HILLIER, 1984).

o papel de filtro com o resíduo desejado era deixado por 12 horas em estufa especialmente regulada a $60^{\circ} \mathrm{C}$. Após esse tempo re tirava-se esse material da estufa, resfriando-se-o em dessecador por 40 minutos, pesando-se-o a seguir.

o conjunto filtrante, acima mencionado, era composto por 2 filtros Sartorius com $47 \mathrm{~mm}$ e diâmetro nominal dos poros de 0,45 $\mu$ superpostos, previamente numerados, lavados, secos e pesados.

A diferença entre o peso do filtro com resỉuo e seu peso prévio, fornece a concentração do material em suspensão, considerado o volume filtrado.

Após essa determinação, os filtros com resỉduos passaram por dispersão ultrassônica, obtendo-se, para cada amostra, uma solu ção.que foi analisada em analisador de partículas finas Coulter Counter TA-II do laboratório de Metalurgia do Pó do IPT. Esta aná lise forneceu a distribuição granulométrica de cada amostra de se dimento em suspensão, de acordo com as seguintes classes:

32,00 a 25,40
25,40 a 20,20
20,20 a 16,00
16,00 a 12,70
12,70 a 10,08
10,08 a 8,00
8,00 a 6,35
6,35 a 5,04
5,04 a 4,00
4,00 a 3,17
3,17 a 2,52
2,52 a 2,00
2,00 a 1,59
1,59 a 1,26
1,26 a 1,00
1,00 a 0,794

Os grupos A, B, C e D correspondem às classes silte Médio, Silte Fino, Silte Muito Fino e Argilla na classificação de Wentworth. 
As implicações desta técnica na interpretação dos resultados serão oportunamente abordadas.

D. Determinação de salinidades

A salinidade das amostras foi estimada pelo equivalente em $\mathrm{NaCl}$ à medição de suas resistividades a $25^{\circ} \mathrm{C}$ em condutivímetro mo delo CM 2A da Toa Eletronics Ltd.

As conversões foram feitas de acordo com o gráfico da FIGU RA 8, usando-se a curva de $75^{\circ} \mathrm{F}$.

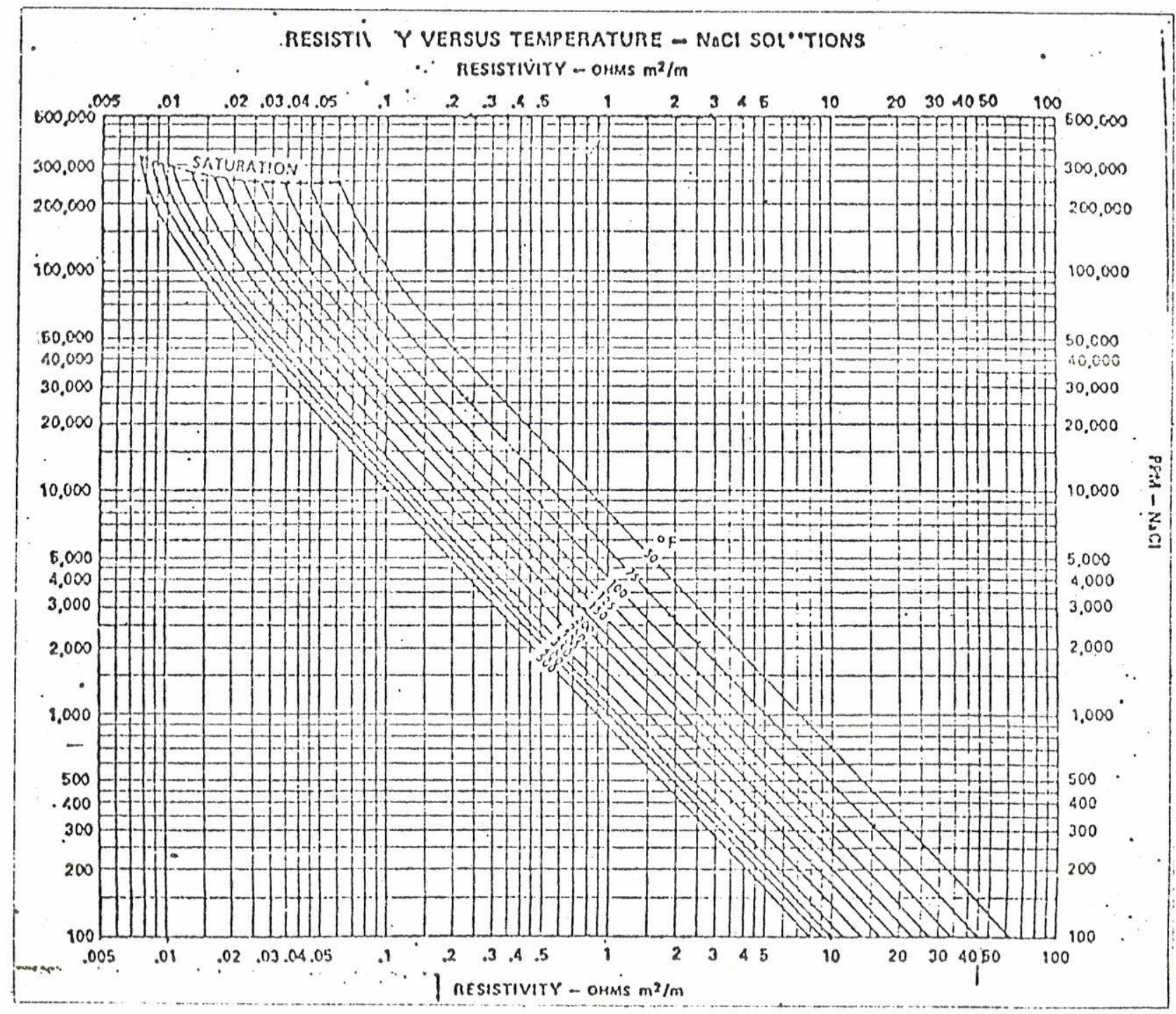

FIGURA 8 - Gräfico para transformação de resistividade em teor em $\mathrm{NaCl}$ (Fon te: Go Wireline Services Gearhart-owen, Formation Evaluation Handbook, 1978).

E. Determinação de teores de matéria orgânica

Estes ensaios foram realizados pelo Agrupamento de Anälises Quimicas e Instrumentais do IPT. Usou-se o método gravimétri. 
trico, de remoção por calor, em duas fases simultâneas. Na primei ra ë pesada uma alíquota de amostra homogeneizada, levada em estú fa a $105^{\circ} \mathrm{C}$ até atingix peso constante; a segunda consiste em pe sar outra alíquota, levada em mufla a $550^{\circ} \mathrm{C}$ atē atingir peso cons tante. O teor em matéria orgânica será correspondente ao material perdido entre $105^{\circ} \mathrm{C}$ e $550^{\circ} \mathrm{C}$.

F. Composição mineralögica

- Agrupamento de petrologia do IPT realizou anälises de minerais pesa dos em vārias dezenas dé amostras, na fração $0,062-0,125 \mathrm{~mm}$, correspondente a areia muito fina na escala de Wentworth. Os resul tados obtidos serão expostos nos capitulos correspondentes.

G. Tratamento estatistico de dados

Os resultados de análises granulométricas, mineralógicas e de salinidade foram tratados por meio de algumas tëcnicas de análise de agrupamento, de tendência e regressão, de programas desen volvidos pelo Grupo de Geoestatística do Agrupamento de Recursos Minerais do IPT, e serão apresentados nos capitulos correspondentes. 
TERMINAIS MARÍTIMOS EM OFFSHORE: O SITIO DE IMPLANTAÇÃO DO TERMI NAL DE ILHA DOS GUARĀS, ESTADO DO PARA.

\section{APRESENTAÇÃO}

Solicitações para estudos geológicos visando a anālise de viabilidade técnica em regiões offshore têm sido escassas. Participamos apenas de dois casos, um interessando a foz do Rio Doce, nas proximidades da cidade de Regência, Espírito Santo, e outro na Ilha dos Guarās, na costa paraense.

No primeiro caso, fizemos uma avaliação sucinta das condi ções de dinâmica sedimentar, com base em cartas nāuticas e informações da literatura, em especial do Projeto Rio Doce (PETROBRĀs/ IGUSP, 1975). Os dados obtidos indicaram grande variabilidade no baixo curso do Rio Doce, mostrada por antigos cursos abandonados, e altas taxas de progradação da costa na região do delta (até 7,3 m/ano). Notamos, ademais, que a sul de Regência, entre as cidades de Barra do Riacho e Vitōxia, a costa é mais recortada, caracteri zada por enseadas e falésias, de tal sorte que a isobbata de 20 m (tomada como referência) se aproxima da costa a menores distâncias que no sitio originalmente proposto. Acresce que, nesse mesmotre cho da costa, e a distâncias maiores que $50 \mathrm{~km}$ da foz do Rio Doce, o estudo dạ PETROBRĀS/IGUSP (1975) demonstra a ausência de diato máceas de ăgua doce, indỉcio sugestivo de que se tratava de região fora da influência da sedinentação deltáica. Concluimos então que, comparativamente, a costa a sul de Barra do Riacho apresentava melhores condições geológicas para aproveitamento da plataforma, alēm de maior facilidade de acesso, tanto em virtude de ausência de áreas pantanosas, como pela menor distância entre a linha de costa e a ferrovia Vitōria-Belo Horizonte. Entretanto, o projeto não teve sequência, de modo que as investigações geolōgicas tiveram seu fim nessa avaliação prévia.

No caso de Ilha dos Guarás, tivemos a oportunidade de desen volver um estudo mais completo, embora ainda de carater essencial mente morfológico, objeto deste capitulo.

A exploração do imenso potencial mineral da serra dos Cara jás, reconhecido quanto aos jazimentos ferro-manganesíferos quan- 
do realizamos este trabalho, impôs de imediato o planejamento de infraestrutura adequada ao escoamento da produção mineral.

Posto que a solução ferrovia-Porto de Itaqui já se mostrasse mais viável, quiz o INPH da PÓRTOBRAS completar a avaliação da alternativa hidrovia - Teminal de Guarás. Para tanto solicitou o parecer de especialistas em oceanografia, jā que esse terminal parecia de difícil viabilização, dadas suas condições de desa brigo e atuação de fortes correntes. Parte dos trabalhos então desenvolvidos , ora apresentados, consistiu em avaliação das condições locais de sedimentação.

Propusemos que esse assunto fosise abordado em duas etapas: . inicialmente uma avaliação da documentação existente, complementada por visita ao campo, se guida, se necessārio, de campanha de campo e ensaios de laboratório mais desen volvidos.

A área de estudo tem seus limites norte e sul nos paralelos $0^{\circ} 15^{\prime} \mathrm{s}$ $0^{\circ} 45^{\prime} \mathrm{S}$, e leste e ceste nos meridianos $47^{\circ} 40^{\prime} \mathrm{W}$ e $48^{\circ} 10^{\prime} \mathrm{W}$, respectivamente (FIGURA 9).

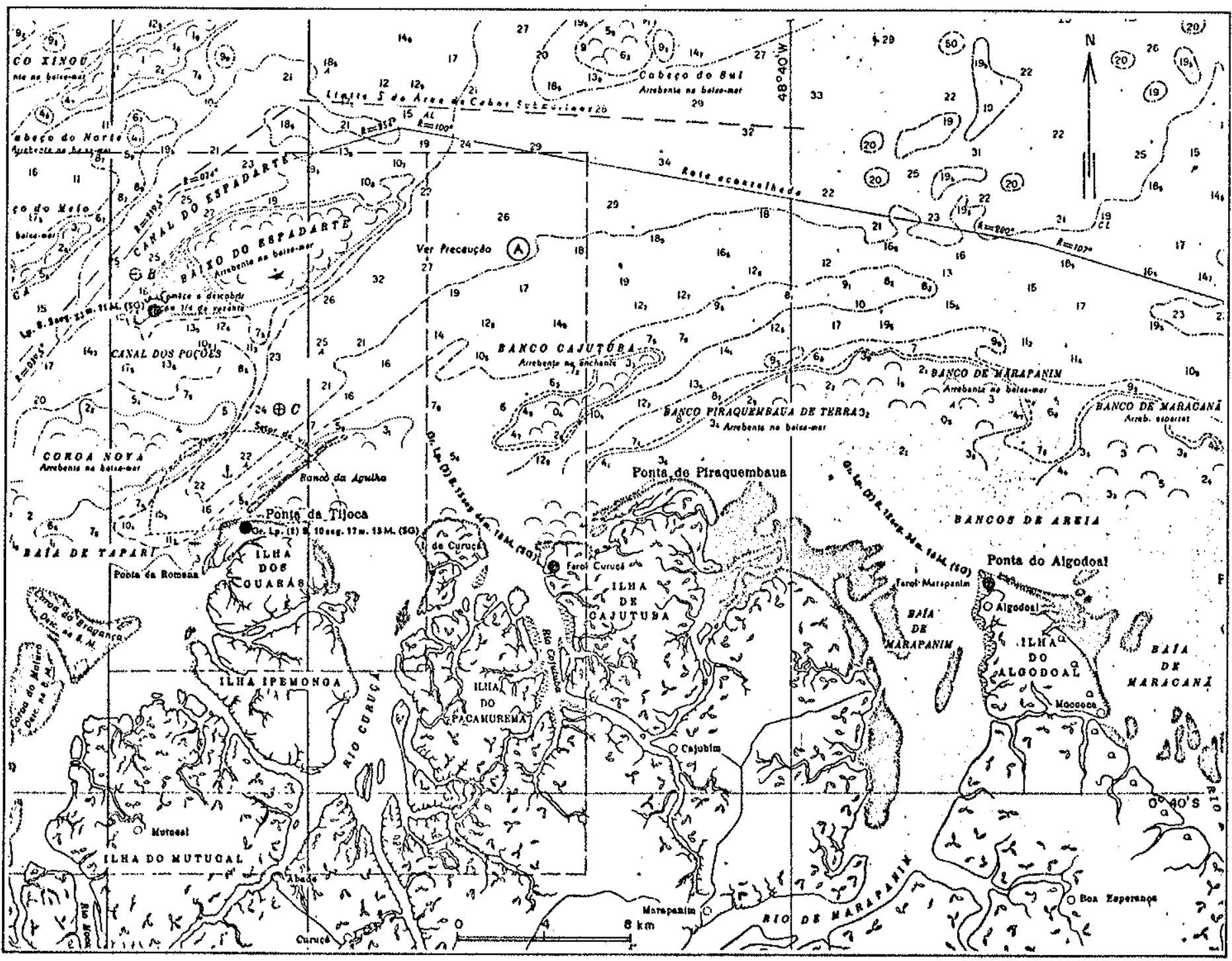

FIGURA 9 - Iocalização àa área estudada. 
Do ponto de vistá geológico, é constituída, em sua parte $e$ mersa, por sedimentos marinhos e continentais atuais e subatuais, predominantemente areias, de idade quaternāria, sobrepostos a argilitos com niveis de cascalho e areia ferruginizada, pertencen tes à Formação Barreiras, de idade miocênica-pliocênica ( FRANCIS CO et alii, 1971), ou mesmo pleistocênica (ARANTES et alii, 1972), (FIGURA I0).

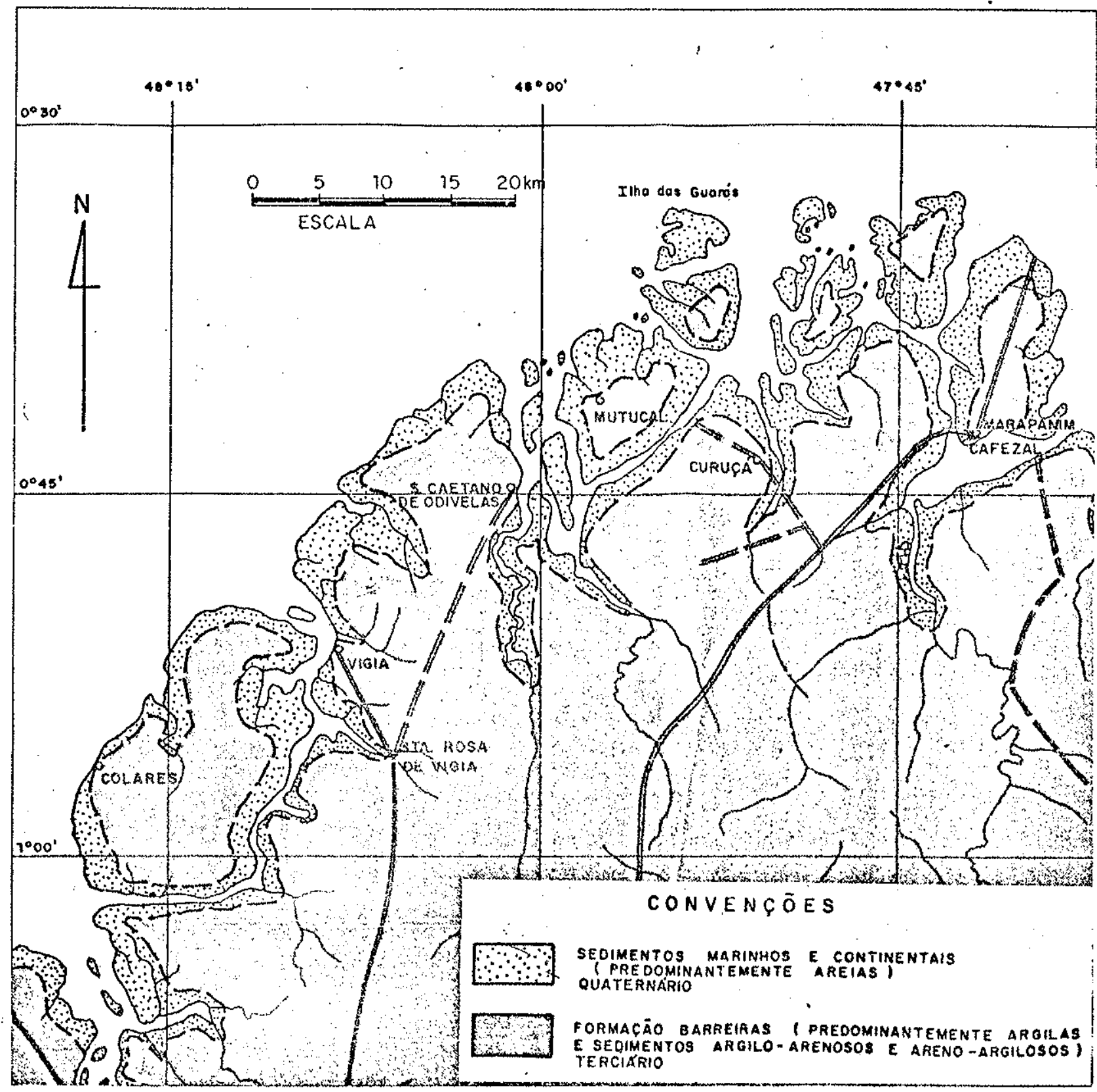

FIGURA 10 - Mapa geológico regional.Fonte: ARANIES et alii (1972) modificado.

A plataforma continental, na ärea de interesse, è constituida esencial mente por sedimentos de fäcies arenosa (ZEMBRUSCKI et alii,1971). 


\section{GEOMORFOIOGIA}

No que se refere à parte emersa, a costa de toda a região é em geral baixa, com cotas máximas em torno de $50 \mathrm{~m}$. Da foz do Rio Pará a noroeste, temos uma costa em progradação caracterizada por depósitos de lama terrígena afeiçoados pelas marés em vasta pla nície costeira. Da foz do Rio pará até a baía de são Marcos a costa apresenta-se extremamente recortada, como costa semelhan te as de rias com pontas e reentrâncias às desembocaduras dos rios. Estas apresentam-se relativamente largas, por comparação às extensões dos cursos d'ägua correspondentes, evidenciando uma his tória de entalhes prëvios e certo carater atual de afogamento.

Dois niveis de falésias podem ser regionalmente reconheci dos: o mais antigo acha-se interiorizado, e sua distribuição é com patível com uma posição do nível marinho de 5 a $10 \mathrm{~m}$ acima da atual. Feições a elas correlacionáveis seriam terxaços de gênese complexa, mantidos por crostas lateriticas, alçados entre 5 a $12 \mathrm{~m}$ de altitude, que definem o nível Belém-Marajó (AB'SABER,1966). Fa lésias atuais ocorrem em Maracanã, Salinópolis e Ponta da Fortaleza.

Quanto à parte submersa, pode-se reconhecer, atravēs da aná lise das cartas batimētricas, uma fase de entalhe que pode ser atribuída ao último evento global de rebaixamento do nivel mari nho.

Embora não seja possível avaliar adequadamente a importân cia dos movimentos tectônicos na história geológica regional qua ternāria, as principais formas de relevo da ārea em foco permitem reconhecer um episódio de entalhe, associado a nivel márinho mais baixo (de provävel idade Würn), um episödio transgressivo, flan driano (fạlēsias fōsseis), seguido do estabelecimento do atual ní vel de base.

Como resultado tem-se uma costa recortada, de que o aspecto afogado pretérito está algo modificado por feições típicas de pro gradação tais como bancos arenosos, cordões litorâneos e campos de dunas. Esta situação é compativel com a proposição de PIMTENTA (1959), que considera toda a ärea de embocadura do Amazonas e Pa rá como um delta intermitente, onde as fases estuarinas seriam efê meras e de curta duração. BAcorcotLI (1971) considera a feição do Golfão Marajoara como parte do complexo deltáico Amazonas-Tocantins. 
Realmente o Amazonas, em virtude de sua elevada carga sedimentar é um rio de construção deltáica, porēm a fase atual, especialmen te a foz do Rio pará, em virtude de seu recente afogamento; pode comportar caracteristicas de circulação estuarina.

E nesse contexto de costa recortada, porém com caracteristicas atuais de progradação,que se encontram a Ilha dos Guarās e o Canal de Tapari, locais examinados com vistas à implantação de um terminal marítimo.

Em superficie a Ilha dos Guaräs é constituída na sua tota lidade por sedimentos holocênicos insconsolidados, representados por areias, siltes e argilas.

Sondagens ai realizadas revelaram a existência de margas calcārias, em média a 35 metros de profundidade, provavelmente da Formação Pirabas (T), imediatamente sotopostas aos sedimentos holocênicos.

Informações fornecidas pela bibliografia existente, não revelaram ocorrência da Formação Barreiras na ilha. Porém, visto que em alguns dos locais perfurados foram descritos arenitos e argilas bastante compactos, acreditamos que possam ser encontrados restos erodidos da Formação Barreiras, capeados por pequenas espessuras de sedimentos holocênicos.

A Ilha dos Guarás apresenta em sụa maior extensão, na dire ção ENE-WSW, $6 \mathrm{~km}$, e na menor, NW-SE 4,9 km. Tal como todo o re levo adjacente, a ilha caracteriza-se por uma linha da costa bai xa e relevo bastante suave. Em vista da amplitude das preama res mëdias de sizigia na ārea, $446 \mathrm{~cm}$, medidas na ponta da Roma na, e pela existência de vários rios e braços de mar, que facili tam a ingressão das äguas marinhas, suas terras são freqülentemen te alagadas.

Dentre as feições morfológicas que merecem destaque, res salta na parte setentrional da ilha uma formação de dunas de areia do tipo longitudinal, que se elevam até 10 metros de altura; e no seu interior planjicies de maré normalmente invadidas pe las águas do mar.

Quanto às feições morfológicás submersas que se desenvolvem nas proximidades da I lha dos Guarás, são de interesse os bancos e cordões de areia, como também os canais que os separam. As prin cipais feições submersas são as seguintes: 
- Baixo do Espadarte: também conhecido como Banco do Bragança, constitui-se em um extenso alto fundo de areia com aproximada mente $14 \mathrm{~km}$ dc extensão por $4,5 \mathrm{~km}$ de largura, que se estende na direção NE-SW e está situado a norte da ponta da Tijoca, de la se separando pelo canal dos poções com cerca de $10 \mathrm{~km}$ de lar gura;

- Coroa Nova localizada a noroeste da ponta da Tijoca, dela se se parando pelo canal de Tapari. que se estende na direção NE-SW e apresenta uma largura em torno de $3 \mathrm{~km}$, com fundos variando de 12 a 25 metros de profundidade;

- Coroa das Gaivotas, constitui um banco de areia com $9 \mathrm{~km}$ de ex tensão por $2 \mathrm{~km}$ de largura, estando localizada a oeste da ilha dos Guarās;

- Mega-ripples (ondas de areia) e rizl marks gigantescos, são tam bém observados nas barras arenosas em frente à ilha Mutucal. provavelmente evidenciando zonas de interferência de correntes. Em sobrevôo de reconhecimento que realizamos de Belém à região de interesse, tivemos a oportunidade de constatar, dada a lim pidez das ãguas, que as ondas de areia são características da plataforma próxima à foz do Rio Pará. As ondas de areia parecem caracterizar grandes estuārios, com vārias dezenas de quilōmetros de largura, em que as velocidades das correntes de maré são elevadas. BOKUNIEWICZ et alii (1977) verificaram que no Es treito de Long Islanả ondas de areia não se formam alêm de um limite de cerca de 10 \% de siltes, ou onde a fração > $1 \mathrm{~mm}$ é sü perior a $12 \%$, tornando mais precisos limites estabelecidos péla literatura prévia.

E importante ressaltar que os bancos de areias apresentam constantes variações em seus contornos, o que è alertado no Rotei ro da Costa Brasileira, publicação DHN n\& DG-1-8, (1968) não sen do porém comum o aparecimento de novos bancos e o desaparecimento de outros. Isto pode ser constatado a partir da carta da Marinha Francesa de 1846 atē as cartas atuais da Marinha, que serão anali sadas mais detalhadamente a seguir.

Quanto à descrição do material de fundo nos canais de Tapa ri e dos Poções deve-se salientar que apresentam caracterização controvertida, visto que no relatório da Companhia Brasileira de 
Geofísica datado de 23 de dezembro de 1972, o local e caracteriza do como areno-siltoso e argiloso, enquanto que na publicação DNH no DG-1-8 o material de fundo è descrito como areia, o que è com pativel com a bibliografia previamente mencionada

(BOKUNIEWICZ et alii, 1977; ZEMBRUSCKI et azii, 1971).

A fim de se caracterizar o comportamento das correntes de marē, dada sua influência na movimentação do material de fundo nas proximidades da Ilha dos Guarās, foram consultados: a Carta da Marinha Brasileira, DHN no 313, correta até 30/08/75, relató rio do DNPVN de junho de 1973 e relatório da Hidrolev sobre a Ilha dos Guarãs, com medições feitas no canal de Tapari. Para uma caracterização global da região foram utilizadas as Cartas de Cor rentes de Maré, Rio Pará, de Salinópolis a Belém, publicação DHN no DG-10-I-1 (1972).

Tomando-se por base os dados fornecidos por esses relatörios, não foi possivel ter-se uma caracterização do comportamento das correntes de maré no canal de Tapari, no que tange a sua in fiuềncia na movimentação de sedimentos de fundo, visto que:

- os dados fornecidos pelas cartas de correntes de maré, DG-10-I-I, são de âmbito regional e se referem à média das correntes de maré, em uma camada d'āgua de aproximadamente 5 metros de es pessura a partir da superficie e não refletem pois, necessariamente, o sentido da movimentação do material de Eundo;

- os dados fornecidos pela carta da DHN no 313, também mostram vá lores muito gerais, não evidenciando ... caracteristicas peculia res à ārea de interesse;

- considerando o regime de águas altas e baixas dos rios da região, que ocorrem geralmente nos meses de jan/fev/mar e set/out/nov, respectivamente, verifica-se que os levantamentos realizados pe lo DNPVN nos meses de set/72 a jan/73 e pela Hidrolev 29/ago a $9 /$ set/72, foram efetuados principalmente em regime de vazante dos rios, e inicio das cheias. Isto leva a crer que as correntes de marē mais efetivas na região não foram observadas, pois nessa época do ano a contribuição dos rios é minimizada. Como exemplo disso, pode-se constatar na publicação DHN no DG-10-I-1, que o período de 18/mar a 31/abr, como o de maior intensidade das cor rentes de maré vazantes e de $18 / j u n$ a $31 / j u 1$, como das maiores 
correntes de maré enchentes

Nesse sentido, as ondas de areia fornecem algumas indica ções adicionais. No sobrevôo realizado, não foi possivel estimar as amplitudes das ondas; entretanto, pareciam apresentar caräter assimëtrico, com face mais inclinada voltada para a plataforma. Em bora LANGHORNE (1973) não concorde que a assimetria seja um crité rio conclusivo para se determinar direção de transporte por ondas de areia, BOKUNIEWICZ (1977) parece ter demonstrado que o tempo necessārio para reverter a direção da assimetria dessas feições é tal que a assimetria pode ser usada como indicador de transporte a longo prazo. Assim, as correntes de fundo nas vazantes seriam mais fortes que as das enchentes.

A fim de se caracterizar as mudanças sofridas nas feições morfológicas emersas e submersas na ilha dos Guarás e adjacências, que são os pontos de maior interesse deste trabalho, torna-se ne cessārio lançar mão de outros elementos, que serão analisados nos tópicos seguintes.

\section{ANALISE DAS VARIAÇÕES DA LINHA DE COSTA}

Em função da relativa mobilidade das feições morfológicas da linha de costa da ärea de estudo, comparamos cartas náuticas e fotografias aéreas de diferentes épocas, com o objetivo de carac terizar os padrões evolutivos para as adjacências da ilha dos Gua ràs.

\section{A. Comparação de Cartas Náuticas}

Para se verificar, em tempos históricos, as variações da li nha de costa nas. adjacências da ilha dos Guarās foram comparados os seguintes documentos: carta da Marinha Francesa no 1108, de 1846 com correções atē 1908, cartas da Marinha Brasileira no 310, 302 e 313 respectivamente de 1958/60/73,60/73 e 60/73.

Dada a maior semelhança de escalas, 1:225 000 da carta fran cesa e 1:200 000 da carta no 310, e ao histórico desta última, cu ja primeira edição de 1958 resultou de uma compilação dos dados do levantamento da Marinha Francesa, maior ênfase foi dada na com paração entre ambas.

o problema inicial, surgido do confronto das cartas nos 
1108 e DHN no 310 é relativo às coordenadas geográficas. Os acidentes topográficos assinalados na carta francesa estão referidos quanto à longitude do meridiano de Parjs, enquanto que as cartas. modernas seguem a convenção internacional de longitudes a partir do meridiano de Greenwich.

Para a comparação das coordenadas geogräficas foram escolhidos três pontos notáveis comuns às duas cartas (1108 e 310): Cate dral de Belēm, Vigia e Ponta de Atalaia.

A correção de longitude do mexidiano de Paris em relação ao meridiano de Greenwich foi feita a partir da indicação de CAUNIN (1972), acrescida de 2' em função da nota de rodapé da carta francesa.

1: Catedral de Belém - ponto representado nas suas cartas com re lativo destaque:

Coordonadas:

Carta Francesa

Carta Brasileira

Longitude

$$
\begin{aligned}
& 50^{\circ} 48 \cdot 00^{\prime \prime} \mathrm{W} \\
& \text { * } 50^{0} 50^{\prime} 00^{\prime \prime} \mathrm{W} \\
& \text { ** } 48^{\circ} 29^{\prime} 46^{\prime \prime W} \quad 48^{\circ} 30^{\prime} 16^{\prime \prime W}
\end{aligned}
$$
$7^{0} 27 \cdot 2.7 \mathrm{~s}$
$1^{\circ} 27 \cdot 18^{\prime \prime S}$ 
2. Vigia - ponto notāvel nas duas cartas e com destaque na carta Francesa, que apresenta um cartão de detalhe em escala maior.

Carta Francesa

Longitude

$* 50^{\circ} 28^{\prime} 00^{\prime \prime} \mathrm{W}$
$* * 48^{\circ} 08^{\prime} 46^{\prime \prime} \mathrm{W}$

Diferença entre as cartas: 07"

Latitude

$0^{\circ} 50^{\prime} 00^{\prime \prime S}$

$0^{\circ} \cdot 51 \cdot 24^{\prime \prime S}$

Diferença entre as cartas: 1'24"

* valor dado na carta

* redução para o meridiano de Greenwich

OBS: não foram acrescentados os 2' na longitude, pois a carta fornece um valor real no cartäo de detalhe

3. Ponta da Atalaia - ponto notável pois conserva até hoje mastro da antiga fortaleza existente no local.

Carta Francesa

Carta Brasileira

Longitude

$$
\begin{array}{r}
49^{\circ} 38^{\prime} 45^{\prime \prime} \mathrm{W} \\
* 49^{\circ} 40^{\prime} 45^{\prime \prime} \mathrm{W} \\
* * 47^{\circ} 20^{\prime} 31^{\prime \prime} \mathrm{W}
\end{array}
$$$$
47^{\circ} 19 \cdot 15^{\prime \prime} \mathrm{W}
$$

Diferença entre as cartas 1'16" Latitude

$0^{\circ} 35^{\prime} 08^{\prime \prime} \mathrm{s}$ $0^{\circ} 35 \cdot 30$ 's

Diferença entre as cartas: $22^{\prime \prime}$

* com acrëscimo de $2^{\prime}$

* redução para o meridiano de Greenwich 
Pelos quadros acima observa-se, portanto, que existem diferenças não só em relação às longitudes como tambēm em relação às latitudes.

Em vista das diferenças não apresentarem um caráter sistemä tico, ou seja os exros são ora para sul, ora para norte, enquanto que os de longitude são ora para oeste, ora para leste, pode-se in ferir que as discrepâncias devem estar ligadas à limitação da pre cisão das tēcnicas empregadas durante a construção da cartà fran cesa.

De fato, segundo MARTONNE (1935), sabe-se que antes da in trođução do telëgrafo sem fio as longitudes eram determinadas pe lo telégrafo aéreo ou por cabo submarino. Segundo informação ver bal do Capitão Tenente Erico José Cavalcanti de oliveira da Dire toria de Hidrografia e Navegação, as longitudes determinadas na é poca da confecção da carta francesa foram obtidas através de um cabo telegráfico submarino. Dessa forma, em virtude das limitações de precisão decorrentes da prōpria determinação, não se deve esperar coincidência de coordenadas determinadas por processo ai. ferentes.

Para a comparação das feições da linha de costa, o passo inicial consistiu na redução, por mētodo fotogrä́ico, da escala de aproximadamente 1:225.000 da carta francesa para 1:200.000, cor respondente à escala da carta brasileira.

o confronto da carta brasileira con um overiay fotográfico jā na escala corrigida, contendo em transparência todos os deta thes da carta francesa, ressalta diferenças grosseiras quanto ao contorno da costa, não sendo possivel a sobreposição da linha de costa marcada em cada uma das cartas.

Para contornar este problema, foram escolhidos três pontos notáveis comuns às duas cartas, e novamente atravēs de método fo tográfico foi tentato o ajuste dos detalhes contidos entre esses pontos. Esta tëcnica que envolve uma maior precisão, é semelhante à utilizada para a correção e transposição de detalhes de fotogra fias aéreas para mapas topogräficos.

Uma vez mais os resultados foram insatisfatórios, persistin do o problema das discrepâncias grosseiras no contorno da costa.

Os resultados das tentativas de ajuste das duas cartas, mos 
traram que qualquer comparação quantitativa entre os detalhes mos trados nas cartas francesa e brașileira são de yalor questionável. Em vista destes problemas, as comparações entre as cartas francesa e brasileira, bem como entre as cartas antigas de baixa precisão, deve ser feito com ressalvas, levando-se em consideração apenas as tendências gerais e apreciações qualitativas. Dentro des te critério podemos observar que:

- a carta francesa apresenta o contorno da costa quase que retili neo, ao contrário da carta brasileira que exibe uma riqueza bem maior de detalhes;

- algumas ilhas que são representadas unidas ao continente ( ilha do Mosqueiro, ilha do Mutucal e ilha pacamurema), apresentam-se afastadas na carta brasileira;

- as maiores diferenças na linha de costa são verificadas a par tir do rio Curuçá em direção a leste;

- ina região próxima a Belëm, os detalhes da linha de costa estão melhor marcados.

Quanto à Ilha dos Guarās, em particular:

- a linha de costa apresenta uma conformação grosseiramente seme lhante à atual;

- a parte sul da ilha, na carta francesa, está quáse unida à Ilha Ipemonga, o mesmo não acontecendo na carta brasileira, onde a distância entre as referidas ilhas ê maior;

- a ponta da Tijoca está representada na carta francesa, "embora não haja um sinal que a localize corretamente.

Quañto à batimetria, embora com as ressalvas anteriores, é possivel constatar o seguinte:

Pontos comuns às duas cartas:

- Baixo do Espadarte - denominado Bane Braganca pelos franceses.

- Canal dos poções - aparente diminuição de profundidade atualmen te, em relação aos dados mais antigos.

- Coroa Nova e das Gaivotas - ambas são representadás nas duas cartas. 
- Canal do Espadarte - embora não haja denominação na carta fran cesa; o referido canal é representado nos dois documentos. Se comparadas as cotas batimētricas, apesar da baixa confiabilidade dos dados franceses, observa-se que a oeste da Coroa Nova as profundidades do canal permanecem as mesmas, enquanto que : as profundidades diminuiram a sudoeste da coroa das Gaivotas.

Pontos não comuns às duas cartas:

- Na carta francesa não são representados alguns bancos, como: Ma racanã, Marapanin, Cajutuba, Piraquembaua de Terra.

- Na carta brasileira nota-se a ausência do Canal de Cassara en tre as Coroas Nova e das Gaivotas, não havendo inclusive regis tro batimétrico.

Quanto à região da Ilha dos Guarás, em particular, observá -se o seguinte:

- o canal existente atualmente (sem denominação), entre a referi da ilha e a Coroa Nova, já estava representado pelos franceses, sendo que permanece o seu sentido SW-NE. Mostra profundidades de 10 a 25 metros na carta francesa e de 10 a 26 metros na carta brasileira.

- Faz-se notar na carta francesa a ausência do banco da Agulha a norte da ilha dos Guarás, o qual.é representado com um alonga mento SW-NE na carta da DHN.

Com relação às edições das cartas modernas, podemos observar que a linha de costa não foi alterada de 1960 para 1973. A permanência do mesmo contorno de costa deve-se à repetição por parte da DHN, dos mesmos dados do levantamento aerofotográfico de 1959, o que não corresponde necessaxiamente à realidade.

As correções introduzidas na edição de 1973, são referentes à batimetria. Assim, as principais mudanças observadas, no tocante aos traços gerais, são:

- Baixo do Espadarte - a mudança ocorrida manifestou-se em quase todo seu contorno, principalmente no sul e sudeste; norte e no roeste não houve mudança apreciável.

- Coroa Nova - seu contorno transformou-se totalmente, sendo que 
foi modificada sua forma e sua ärea aumentada consideravelmente.

A ayaliação das mudanças batimétricas ocorridas no periodo de $1960 / 1973$ serão retomadas mais adiante com maior detalhe.

B. Fotografias Aēreas

Foram examinadas fotografias aéreas tomadas em três pèrio dos de tempo diferentes, correspondendo aos anos de 1959,1968 e 1972, respectivamente. Os levantamentos de 1959 e 1972 , respectivamente nas escalas de 1:30 000 e 1:100 000, são da Seção de Aero fotogrametria da Diretoria de Hidrografia e Navegação. O levantamento de 1968, na escala de 1:100 000, é da USAF.

Para maior facilidade de comparação, as fotos dos diferen tes levantamentos foram reduzidas à mesma escala de 1:60 000.

1. Caracteristicas Regionais

A observação das fotografias aéreas da ārea de interesse mos tra como principais feições morfológicas planícies dominadas por marés, cordões litorâneos, campos de dunas, e numerosos bancos arenosos periodicamente submersos pelas marēs.

Nota-se que, as planỉcies de maré, os cordões litorâneos, e os bancos costeiros, são feições que se deșenvolvem com maior fre quência onde hã a ação direta do mar, embora os manguesais possam estender-se tambëm para o interior da embocadura dos rios, atestando a influência das marés até estes locais.

A presença de sucessivos cordões litorâneos paralelos e de bancos costeiros dispostos nas principais ilhas da região, indica a afetiva ação construtiva do mar no modelado da linha de costa. o material sedimentar trazido tanto pelos rios como por correntes costeiras. ë retrabalhado por processos marinhos, dando origem a cordões litorâneos, barras e bancos costeiros.

Numerosos bancos costeiros e cordões litorâneos, estão atual mente em desenvolvimento, nas ilhas e pontas da região costeira.

Nas illhas Guarás, Curuçā e Cajutuba o crescimento dos bancos arenosos atuais se dá preferencialmente nas faces voltadas pa ra leste. A forma destes bancos assemelha-se a um leque, com aba voltada também para leste.

Essa morfologia sugere a existência de uma corrente litorânea sentido W-E que estende-se da Ilha dos Guarās até as proximi 
dades da ilha do Algodoal. Essa corrente teria ação restrita a apenas poucas centenas de metros da costa, e sentido oposto ao da corrente oceânica.

A presença da corrente litorânea $\mathrm{W}-\mathrm{E}$ seria ainda endossada pelo padrão de dispersão das águas dos rios que desaguam nes sa região. As águas dos rios, em virtude de sua carga em suspensão aparecem nas fotos aéreas em tons cinza claro, e acham-se de fletidas para $\mathrm{NE}-\mathrm{E}$, indicando o sentido da corrente litorânea.

Quanto à interpretação das unidades litológicas, nas fotos dos levantamentos de 1968 (USAF), e de 1972 (DHN), observam-se pe quenas elevações com texturas diferenciadas nas ilhas Ipemonga e Mutucal ( a S da I ha dos Guaräs), Pacamurema e Cajutuba (a E da I Iha dos Guarās), que podem corresponder a sedimentos da Formação Barreiras. Essas elevações apresentam-se sob a forma · de "ilhas" dentro dos sedimentos quaternários, e algumas vezes es tão cobertas por areias eólicas.

Da Ilha dos Guarás para E a partir da Ilha Pacamurema, são cada vez mais İrequentes as exposições dos sedinentos terciārios da Formação Barreiras. A FIGURA 11 mostra as principais feições observadas através das fotografias aēreas.

2. Ilha dos Guarás e Proximidades

Pelo exame das fotografias aéreas, especialmente as do le vantamento de 1959, que estão em maior escala, pode-se observar cordões litorâneos antigos truncados, dispostos em linhas onde freqthentemente se instalam pequenas drenagens.

Seguindo-se esses antigos cordões litorâneos, ' observa-se que em épocas pré-atuais a Itha dos Guarās possuía uma forma mais elíptica com aproximadamente 5 e 3,5 km respectivamente para os eixos maior e menor que, grosso modo', orientam-se a N-S e E-W (FIGURA 11).

Dessa época para cá, sucessivos cordões litorâneos foram sendo construídos progressivamente nas faces norte, nordeste e este, acarretando um aumento da ärea emersa da ilha, de aproxima damente $6 \mathrm{~km}^{2}$. Esse crescimento mudou a forma eliptica para uma forma mais circular.

- crescimento mais pronunciado deu-se na face $\mathrm{N}$ da ilha, on de pode-se observar cerca de 1300 metros de crescimento. As faces 


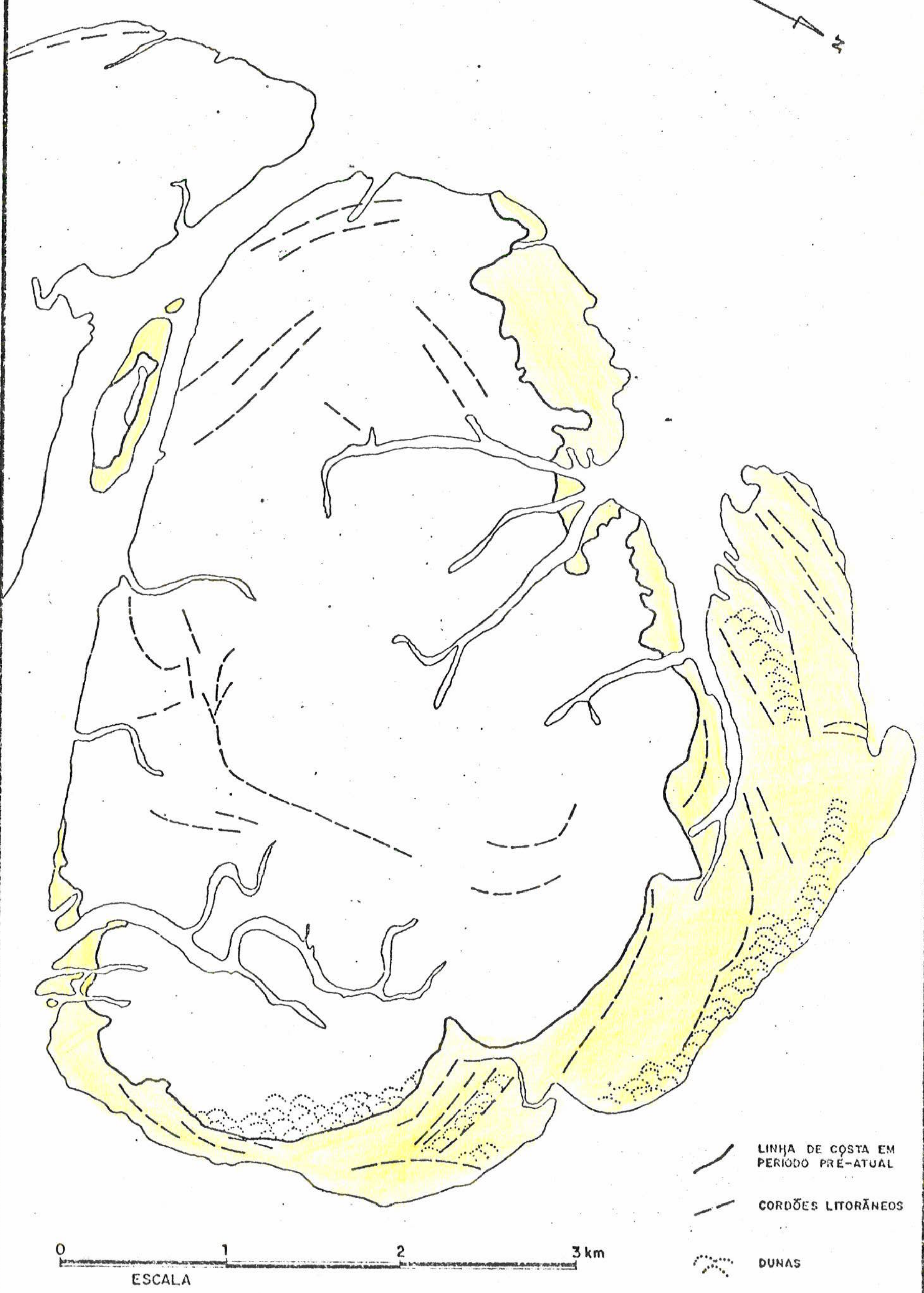

FIGURA 11 - Esboço geomorfológico da Ilha dos Guaräs. 
S e SW (furo Croatä), que estão protegidas da ação direta do mar, não acompanharam o mesmo ritmo de crescimento.

As areias depositadas nos cordões litorâneos são frequentemente remobilizadas pela ação do vento formando pequenos campos de dunas longitudinais. Onde a vegetação ainda não cobriu totalmente as areias eólicas são observadas, nas fotos, texturas mui to claras como na face $\mathrm{N}$ e $\mathrm{E}$ da Ilha dos Guarās.

Os cordões litorâneos são separados por sulcos retilínios, que algumas vezes apresentam pequenas. lagunas.

o crescimento na face $N$ e NW deu-se preferencialmente pela acreção de cordões litorâneos sobrepostos a bancos arenosos cons truídos pelas marēs, enquanto que na face $\mathrm{NE}$ e $E$ O crescimento deu-se mais pela acreção de sucessivos cordões litorâneos, com re trabalhamento pelo vento, formando campos de dunas (FIGURA II).

Pelo exame das fotografias aéreas do levantamento de .1968 (USAF), alēm das características acima mencionadas; pode ser ob servado um crescimento atual mais pronunciado na face NW da Ilha dos Guarās (FIGURA 12).

Algum cuidado deve ser tomado na comparação da linha de cos ta em dois levantamentos aerofotogramétricos de épocas aiferentes, em virtude das variações de maré serem de grande amplitude na área (446 cm na Ponta da Romana, DHN). Dessa forma, um dado le vantamento pode ter tomado as fotografias durante, a preamar, e outro durante a baixa mar, o que levaria a uma idéia falsa de um crescimento exagerado da linha de costa.

As fotos manipuladas não fornecem informações precisas da hora, dia e mês do levantamento aerofotogramêtrico, tornando difí cil a constituição das conḍições de marē. Dessa forma, o critērió aqui estabelecido para a comparação tomou como base as äreas de acréscimo onde a vegetação jă tenha se fixado, e portanto indicativas de um efetivo crescimento da linha de costa.

Dentro desse critêrio, observou-se que a NW da Ilha dos Gua rás (W da ponta do Tijoca), houve um crescimento de 60 metros da linha de costa no periodo de 1959 a 1968 (9 anos), devendo se to mar esse valor como minimo para o local em questão, já que exten sas faixas arenosas são visivelmente mais largas no levantamento de 1968. 
Este local (W da ponta da Tijoca) mostrou maior crescimento no período considerado, porēm todas as faces da ilha dos. Guarás voltadas para o mar mostram, em major ou menor grau, indicios de crescimento no mesmo período.

Até o furo Croatá (S da Ilha dos Guaräs), que pela fotoin texpretação anterior não havia crescido significativamente em épo cas pré-atuais, mostrou uma certa retificação nesse perīodo, com - aparecimento de 2 novas ilhas e certo estreitamento de seu ca nal principal.

Na embocadura da drenagem a $S$ da ponta Romana, na face SW da Ilha dos Guarás, tambēm apareceram novos bancos arenosos que não eram visiveis no levantamento de 1959.

Quanto à orientação das drenagens das faces NW e SW da IIha dos Guarās, vale acrescentar que têm sua saída voltada para $\mathrm{SW} e$ são orientadas de $\mathrm{NE}$ para SW, acompanhando a orientação do canal de Tapari. Isto sugere uma forte ação das marés enchentes que , remobilizando o material arenoso de fundo, impedem a saída dessas arenagens em outra äireção.

A boa qualidade das fotos do levantamento de 1968 permite ainda diferenciar na ärea coberta pelas äguas, diferentes tons de cinza que sugerem a forte ação das marēs no canal de Tapari. Os tons de cinza claro a esbranquiçado devem indicar āguas com eleva da carga sedimentar, em contraposição aos tons cinza escuros, que devem representar águas oceânicas com pequena carga em suspensão. As saỉas de outros rios como o Curuçā, por exemplo, tambēm apre sentam a influência das águas oceânicas movimentadas por maré, po rēm em menor grau, sendo que as äguas com carga em suspensão avan çam mais para o mar. A orientação das entradas de ãguas oceânicas são $S W-N E$, passando para SWW-NEE, à medida que se caminha para a ilha Cajutuba (rumo a leste).

o exame das fotografias do levantamento de 1972, embora pre judicado pela má qualidade das fotos, cobertura de nuvens, escala um tanto reduzida, e mesmo pela pequena defasagem de tempo, indicou as mesmas tendências de crescimento anteriormente expostas. A face NW da Ilha dos Guarás mostou-se uma vez mais, como o local de maior crescimento. (FIGURA 12).

Todas as faces da Ilha dos Guarás voltadas para o mar, embo 

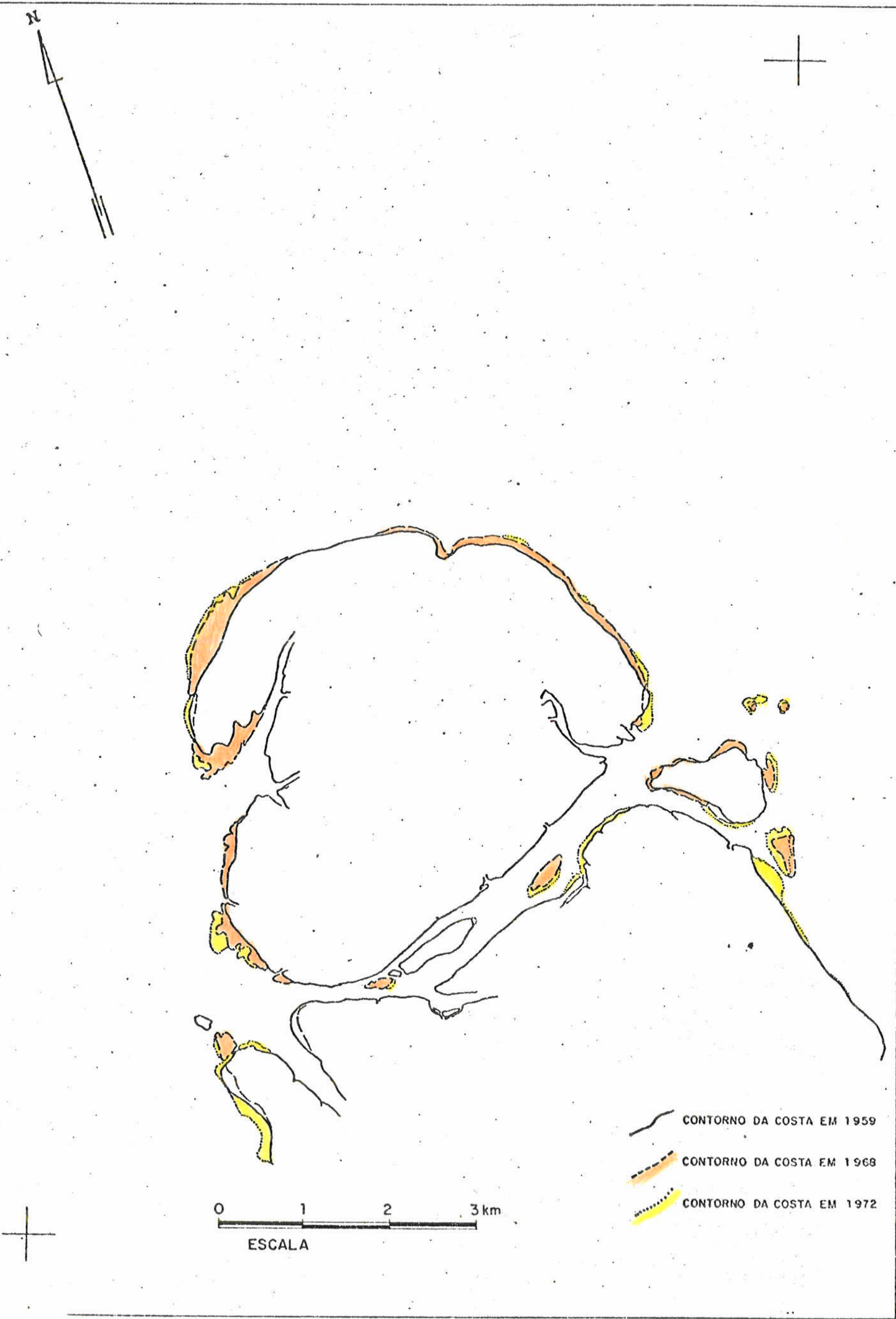

FIGURA 12 - Variações da linha de costa, de 1959 a 1972 
ra em menor grau, também apresentaram uma vez mais indícios de crescimento, evidenciados atravēs de maior cobertura vegetal ras teira, em áreas onde havía exposição arenosa na ēpoca do levantamento da USAF.

o crescimento foi em menor grau, porém deve-se levar em con sideração que o intervalo de tempo foi de apenas 4 anos.

o exame do conjunto de informações fornecidas pelas fotogra fias aéreas mostra que a Ilha dos Guarás está em constante evolu ção, tendendo a ampliar a sua ārea emersa atravēs do tempo.

o crescimento mais acentuado deu-se na face NW onde, no pe ríodo de 1959 a 1968, houve um crescimento de pelo menos 60 me tros na área vegetada, sendo que se pode estimar um crescimento total de valor ainda maior.

A taxa mínima de crescimento anual constatada para essa área é de cerca de $7 \mathrm{~m} / a n o$. Em outras āreas as taxas são seguramente inferiores, porém, um efetivo crescimento pode ser observado atra vés dos bancos costeiros e praias, que vêm aumentando sua ārea e mersa ao longo do tempo.

\section{ANALISE DAS VARTAÇÕES BATIMETRICAS}

A comparação de cartas batimētricas de diferentes períodos tem a finalidade de esclarecer as modificações morfoloogicas da li nha de costa e da superfície do fundo, bem como avaliar o volume de material movimentado, de modo a identificar o padrão da dinâmi ca atual de sedimentação no que diz respeito à razão de erosão/di posição de sedimentos.

Esses trabalhos foram realizados comparando-se cartas da Marinha Brasileira, correspondentes aos levantamentos de 1959-1960 e 1972, efetivando um periodo de 12 anos para o estudo dessas va riações.

Num estudo mais amplo da área foram utilizadas duas cartas no 302, na escala 1:100 000 - la. edição publicada em 1960, com grandes correções até 1962, e 2a. edição publicada em 1973 e corrigida atë 1975 - e duas cartas no 313, na escala de 1:50 000 1a. edição 1960 com grandes correções até 1962 e 2a. edição corri gida atē 1975 .

Para uma anālise detalhada do canal de Tapari foram utili- 
zadas as folhas de bordo referentes ao levantamento de 1959-1960 e 1972 nas escalas de 1:50 000 e 1:10 000 respectivamente.

No estudo.das modificações morfológicas da linha de Costa alēm das cartás acima mencionadas foram analisadas outras cartas da Marinha Francesa, Marinha Inglesa e Marinha Amexicana corres pondentes a levantamentos executados no século XIX.

A. Obtenção de Dados a Partir das Cartas da DHN nos 302 e 313 e das Folhas de Bordo.

Para a obtenção dos dados a partir das cartas batimëtricas da Marinha Brasileira, no 302 e no 313, a área em estudo foj. sub dividida em 3 setores, conforme mostra a FIGURA 13.

SETOR A, no canal de Tapari em frente a Ilha dos Guarás com eixo orientado NE-SW, caracterizando a área de interesse; SETOR $\mathrm{B}_{\text {, }}$ compreendendo o canal dos Poções localizado ao sul do Baixo do Es padarte e com eixo orientado na direção E-W; e SETOR C, compreende a continuação do canal de Tapari que foi considerado como ärea complementar as duas primeiras.

$\mathrm{Na}$ obtenção dos dados dessa fase foram realizadas as seguintes etapas de trabalho para as 4 cartas estudadas:

- interpolação de curvas batimétricas em intervalos de 2 metros a partir da cota - $5 \mathrm{~m}$;

- locação de duas linhas de origem para os perfis, a fim de se evitar erro de deslocamento de pontos nos perfis durante a com paração, sendo locada uma para o canal de Tapari, passando pe las coordenadas $47^{\circ} 50^{\prime} \mathrm{W}-0^{\circ} 30^{\prime} 30^{\prime \prime} \mathrm{S}$ e $47^{\circ} 49^{\prime} 30^{\prime \prime} \mathrm{W}-0^{\circ} 30^{\prime} \mathrm{s}$ e ou tra para o canal dos Poções, passando pelos pontos. $47^{\circ} 57^{\prime} \mathrm{W}-$ $0^{\circ} 31^{\prime} \mathrm{S}-47^{\circ} 50^{\prime} \mathrm{W}-0^{\circ} 31^{\prime} \mathrm{s} ;$

- locação de perfis perpendiculares à linha de origem, espaçados em 1000 metros sendo: 14 no setor $A$ (perfis de 1 a 14), 7 no setor B (perfis de 22 a 28) e 7 no setor C (perfis de 14 a 21).

Para cada par de cartas estudadas, a anālise dos elementos obtidos foi feita plotando-se os perfis levantados em gráficos com escala horizontal de 1:20 000 e escala vertical 1:1 000, sendo os perfis correspondentes sobrepostos a fim de se determinar as modi ficações topogräficas do fundo, caracterizando locais de erosão 


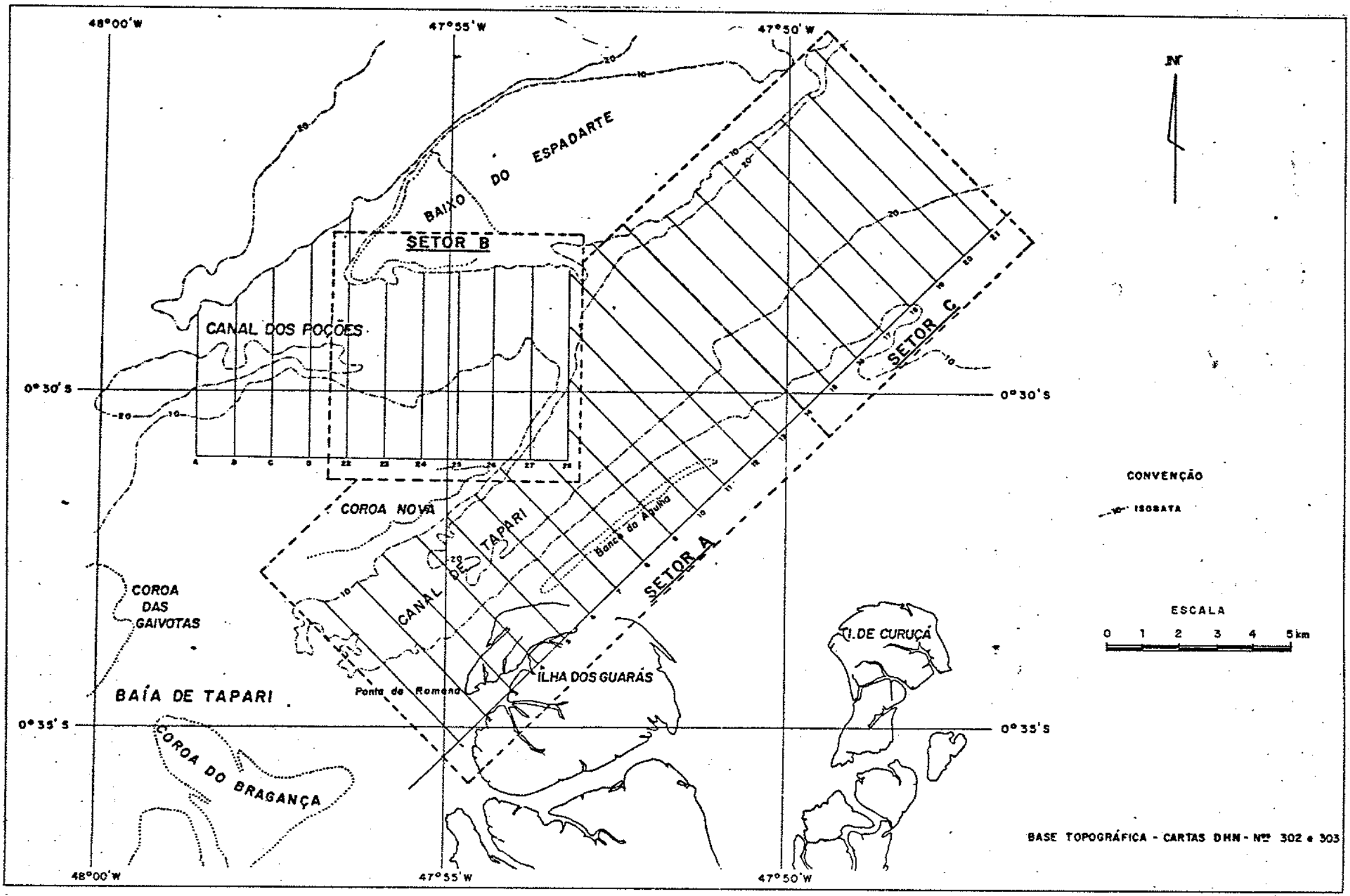

FIGURA 13 - Dịstribufição dos setores para análise de variações batimëtricas 
e deposição.

Para o estudo de detalhe no setor A no canal de Tapari: em frente à Ilha dos Guarās, foram utilizados os dados disponíveis nas folhas de bordo correspondentes aos levantamentos 1959,1960 e 1972 nas escalas de 1:50 000 e 1:10 000 respectivamente. Desta feita não foram interpoladas curvas batimētricas devido à grande quantidade de pontos disponiveis nas folhas, que deram maior pre cisão aos perfis.

Os trabalhos desta fase percorreram as seguintes etapas:

- locação de linha de origem para os perfis passando pelas coorde nadas $47^{\circ} 55^{\prime} \mathrm{W}-0^{\circ} 35^{\prime} \mathrm{s}$ e $47^{\circ} 50^{\prime} \mathrm{W}-0^{\circ} 30^{\prime} \mathrm{s}$;

- locação de 14 perfis perpendiculares à linha de origem espaça dos de 1000 metros, a partir do ponto $47^{\circ} 55^{\prime} \mathrm{W}-0^{\circ} 35^{\prime} \mathrm{s}$;

- execução e comparação de perfis correspondentes, para determina ção das āreas sujeitas à deposição e erosão;

- execução de planta de localização das āreas de movimentação, a fim de determinar o arranjo espacial do padrão de sedimentação.

Os resultados obtidos nas cartas năuticas e folhas de bordo são mostrados na FIGURA 14.

B. Cálculo do Volume do Material Movimentado no Período 1959,1960 a 1972 .

Para o cálculo de material movimentado no período considera do de 12 anos, foram utilizados os perfis batimétricos e as plantas de localização.

A partir dos perfis executados, foram anotadas as äreas on de houveram variações de profundidades, sendo essas variações ava liadas por contagem de milimetro quadrado inscrito.

Nas plantas executadas na escala de 1:50 000 foram plotados os intervalos de movimentação, a fim de se determinar os locais de erosão e deposição e os valores de áreas calculadas anterior mente através dos perfis.

Este procedimento foi adotado tendo-se em vista definir for mas geomëtricas mais regulares, e ao mesmo tempo, introduzix um modelo de arranjo espacial para os locais de movimentação de fundo, permitindo desta forma o cálculo dos volumes do material movi 


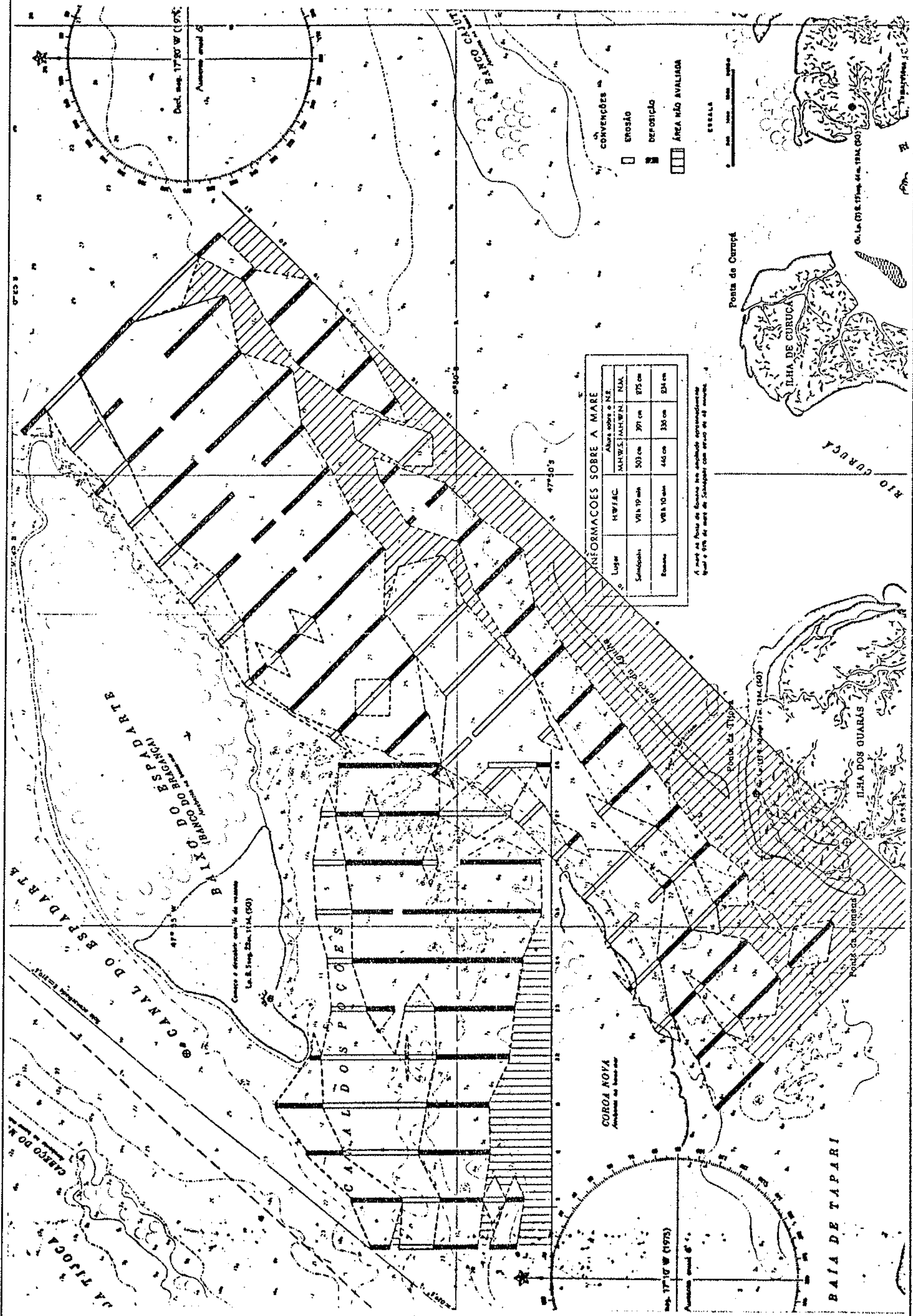

FIGURA 1.4 - Areas de erosão e deposição, determinada atravēs da comparação de car tas näuticas e folhas de bordo. 
mentado.

Os contatos entre os locais de movimentação foram construí dos geometricamente, isolando-se corpos de formas prismática e piramidal. Os corpos de forma piramidal foram estabelecidos levan do-se contra o critêrio de ărea de influência à meia distância, quando processos antagônicos (erosão/diposição) ou término da ação de um dado processo, ocorriam em perfis contiguos. os resul tados obtidos são apresentados por setor nas tabelas que seguem:

\section{SETOR A - CANAL DE TAPARI}

Volume de Material Área de Deposição Taxa de Deposição

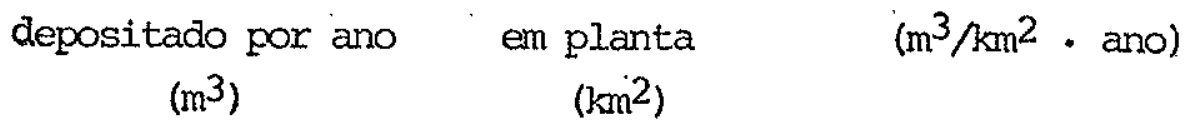

Carta no 302 3926666,6 25,9625 151243,77

Carta no 313 3919583,3 19,7775 198183,96

Folha de Bordo

3255000,0

19,6125 164965,58

Valores Mëdios

3700416,0

21,8000

171979,00

Volume de Material Área de Erosão Taxa de Erosão erodido por ano $\left(\mathrm{m}^{3}\right)$ em planta $\left(\mathrm{m}^{3} / \mathrm{km}^{2} \cdot \mathrm{ano}\right)$

Carta no 302

$$
4757083,3
$$

24,3870

195066,35

Carta no 313

4069375,0

14,7850

275236,72

Folha de Bordo

3803333,3

22,5130

168939,42

Valores Médios

4209930,0

20,6000

213,08 
Carta n: 302

Carta no 313

Valores Médios

Carta no 302

Carta no 313

Valores Médios

Carta no 302

Carta no 313

$$
1698750,0
$$

6,9370

244882,51

20,3250

201681,01

3107083,3

15,9375

194954,24

3603124,0

18,1000

198317,00
erodido por ano $\left(\mathrm{m}^{3}\right)$
Volume de Material Área de Erosão Taxa de Erosão
em planta
$\left(\mathrm{m}^{3} / \mathrm{km}^{2}\right.$, ano)

$\begin{array}{rll}1698750,0 & 6,9370 & 244882,51 \\ 707083,3 & 6,4875 & 108991,65 \\ 1202916,6 & 6,7000 & 176937,00\end{array}$

SETOR C - CONTINUAÇÃO DO CANAL DE TAPARI

Volume de Material Area de Deposição Taxa de Deposição depositado por ano $\left(\mathrm{m}^{3}\right)$
em planta$$
\left(\mathrm{km}^{2}\right)
$$
$\left(\mathrm{m}^{3} / \mathrm{km}^{2}\right.$. ano $)$

$$
3637083,3
$$

29,0000

125416,66

Valores Médios

2706666,6

22,7375

119039,76

Valores Medios

3171874,0

25,9000

122228,00

Volume de Material Area de Erosão ' Taxa de Erosão erodido por ano $\left(m^{3}\right)$ em planta
$\left(\mathrm{km}^{2}\right)$

Carta n: 302

$$
501250,0
$$

6,0432

8294,78

Carta no 313

1074166,6

6,4375

16686,83

Valores Médios

6,2000

12490,00 


\section{Discussão dos Resultados}

o mētodo. comparativo de anālise cartogräfica utilizado fornece dados numëricos que devem ser considerados como ordens de grandeza.

Utilizando-se plantas de localização das āreas de deposição e erosão podemos observar um padrão de sedimentação altamente coincidente caracterizando os estudos efetuados, como também le vantar evidências sobre a dinâmica de sedimentação na ārea.

No SETOR A, que compreende o canal de Tapari em frente a Ilha dos Guaräs, pode-se observar tendência deposicção junto à linha de costa, enquanto que do outro lado do canal predomina caráter erosivo. Este padrão de movimentação de sedimentos implica em mudança da faixa de maiores profundidades do canal no senti do SE-NW, sem que haja assoreamento do mesmo, visto que as profun didades se mantêm aproximadamente as mesmas durante o periodo de 12 anos. Nos perfis 7 e 8 , em particular tomando-se como referêncía a cota - $10 \mathrm{~m}$, nota-se que as seções transversais ao canal, correspondentes a 1972, apresentam contornos semelhantes ao de 1959/60, porēm a faixa de maiores profundidades, abaixo da cota $10 \mathrm{~m}$, está deslocada de cerca de $200 \mathrm{~m}$ no sentido $\mathrm{NW}$. Isto nos dá, para o período de tempo considerado, uma taxa de migração da faixa de maiores profundidades de cerca de $16 \mathrm{~m} / \mathrm{ano}$.

Os cālculos efetuados indicam predominio de erosão neste se tor, com taxa mëdia de erosão de $420.000 \mathrm{~m}^{3} / \mathrm{km}^{2}$. ano distribuí dos numa área de $20,6 \mathrm{~km}^{2}$.

Esses dados evidenciam que o fluxo constante de correntes de marē no canal de Tapari, permite a manutenção do canal com pro fundidades aproximadamente constantes, variando porém, a faixa de maiores profundidades.

- SETOR B, representado pelo canal dos Poçöes, mostra predo mínio de deposição no seu lado sul como tambēm na confluência com - canal de Tapari, evidenciando tendência fortemente deposicional, com direção de progradação no sentido $S-N$. Esse carāter é confirmado pelas taxas de material depositado que atinge neste setor uma média de $3600000 \mathrm{~m}^{3} / \mathrm{km}^{2}$. ano para uma ärea de aproximadamen te $18 \mathrm{~km}^{2}$.

Essa tendência deposicional também prevalece na ārea abrangi 
da pelos perfis A, B, C e D, locados mais a oeste, não apresentando porém, taxas tão elevadas.

Cabe ressaltar ainda o carāter erosivo que se manifesta no SETOR B, junto ao Baixo to Espadarte, mostrando mais uma vez a téndência de movimentação dos canais da ārea de estudo no sentido SSE-NNW.

SETOR C, compreende a continuação do canal de Tapari, ten do eixo com mesma orientação do SETOR A, SW-NE. Mostra acentuada tendência de deposição junto à linha de costa, como tambëm no cen tro do canal. A margem norte do canal, junto ao Baixo do Espadarte apresenta desenvolvimento de erosão, tal como o SETOR A, fato esse mostrado claramente nos perfis 15,16 e 17.

Cabem ainda algumas considerações quanto ao gradiente das margens do canal de Tapari, visto que elas são tambēm indicativas do carāter deposicional nas proximidades da linha de costa, evidenciado nas aexofotos, onde inclinam-se suavemente em direção ao centro do canal, indicando um avanço constante de material no sen tido SE-NW. O mesmo jä não ocorre junto ao Baixo do Espadarte on de as margens têm carāter abrupto, denotando acentuada erosão, ó que é evidenciado tanto pela densidade das curvas batimêtricas das cartas no 313 e 302 como pelos perfis.

Os valores numéricos calculados para o SETOR C mostram pre domínio de deposição, com uma taxa anual de $3170000 \mathrm{~m}^{3} / \mathrm{km}^{2}$. ano distribuídos numa área de aproximadamente $25,9 \mathrm{~km}^{2}$.

Levando-se em conta a anālise dos 3 setores estudados fica clara a predominância de deposição na maior parte da região, res salvando-se que o Canal de Tapari tende a manter sua profundidade. Contudo, a presença constante de faixas de deposição junto à 1 i nha de costa, o gradiente das margens do Canal de Tapari, a ação erosiva junto ao Baixo do Espadarte e os deslocamentos observados na faixa de maiores profundidades do canal, evidenciam que o pa drão de sedimentação se mantēm em equilíbrio, porēm constantemente deslocado no sentido SE-NW numa razão em torno de $1.6 \mathrm{~m} / \mathrm{ano}$, pa ra o intervalo de tempo em que hă dados disponíveis. 
$\mathrm{V}$ TENDENCIAS EVOLUTIVAS DA SEDIMENTAÇÂO NAS ADJACENCIAS DA ILHA DOS GUARÁS.

A Ilha dos Guarās é constituĩda por sedimentos quaternários holocênicos, predominantemente arenosos, dispostos em cordões li torâneos, planỉcies dominadas por marēs e bancos costeiros. Não se observam afloramentos de sedimentos da Formação Barreiras, po rēm as indicações dadas por algumas sondagens e por observações de fotos aéreas fazem supor que pequenas espessuras de sedimen tos quaternārios possam estar capeando restos erodidos dessa for mação.

Num contexto mais amplo, a. Ilha dos Guarás situa-se na mar gem leste da foz do rio Pará, enquadrando-se portanto no limite leste do complexo deltáico-estuarino do Amazonas. As embocaduras de rios de construção deltáica são caracterizadas por intensa sedimentação que favorece uma rápida progradação da linha de cọ ta. A foz do rio Pară, especialmente na atual fase, não eviden cia um modelo deltáico estrito, aproximando-se mais de um estuá rio que estaria evoluindo para uma fase mais francamente deltäi ca.

A transição entre um modelo estuarino, em que as taxas de sedimentação e exosão tendem a equilibrar-se, e um modelo deltăi co, caracterizado por intenșa sedimentação e progradação da 1 i. nha de costa, é indicada na área da I Iha dos Guarás por uma li nha de costa recortada, já em franco processo progradacional, evidenciado pela construção de numerosos bancos costeiros e de cordões litorâneos.

o equilíbrio entre as condições deltãicas e estuarinas de pende grandemente do aporte sedimentar dos rios alimentadores, da energia do mar como agente dispersivo de sedimentos, e das condi ções de estabilidade tectônica (subsidência) da ārea de deposi ção.

Para a ārea em questão a literatura prévia indica acentuada subsidência quaternária, e ao mesmo tempo uma elevada energia do meio receptor, o que acarreta relativo equilíbrio no crescimento do pacote sedimentar. Porém, uma vez aumentada a carga sedimentar, ou havendo decréscimo de subsidência, pode-se ter novamente um predomínio do crescimento deltáico no sentido de progradação da 
linha de costa, que em um ritmo muito acelerado pode afetar a pró pria vida ütil de certas obras de engenharia.

No que se refere às pxoximidades da Ilha dos Guarảs, o es tudo comparativo de cartas náuticas antigas e modernas, mostrou que o Canal de Tapari é uma feição que se manteve em tempos histó ricos com profundidades muito semelhantes à atuais.

o exame de fotografias aëreas de três levantamentos distan ciados no tempo entre si, repectivamente de 9 a 4 anos, num to tal de 13 anos, mostrou um efetivo crescimento da Ilha dos Guarás, no periodo considerado.

Esse crescimento, que através de fotointerpretação pôde ser observado desde épocas prē-atuais, se faz predominantemente por acreção de sucessivos cordões litorâneos e de bancos arenosos costeiros.

o crescimento mais pronunciado no período considerado é da ordem de até $100 \mathrm{~m}$ na ärea emersa, dando-se na face $\mathrm{NW}$ da ilha, com o sentido de SE para NW (em direção ao Canal de Tapari), cor rospondendo a uma taxa de crescimento de aproximadamente $7 \mathrm{~m} / a n o$. $\mathrm{Na}$ parte submersa esses valores podem ser menores, porëm um efeti vo crescimento é sugerido pelo aumento das áreas de exposição dos bancos costeiros.

A análise da movimentação de material de fundo, atravēs de comparação de cartas náuticas, mostrou claramente que o canal de Tapari tende a manter sua orientação e profundidades, porém não à mesma posição. A tendência de crescimento da Ilha dos Guarás , mostrada nas fotos aēreas, e também marcada na parte submersa,por sedimentação na face SE do canal, enquanto que sua face NW sofre erosão.

Os volumes de material erodido e depositado, calculados pa ra o Canal de Tapari, em valores absolutos são razoavelmente pró ximos, mostrando que o canal é uma zona de passagem de sedimentos carregados por correntes de maré. Apenas o canal dos Poções apresenta uma tendência mais forte de deposição, porēm esta sedimenta ção obedece a um padrão direcional com sentido de $\mathrm{S}$ para $\mathrm{N}$, sendo a zona $\mathrm{N}$ do canal dos Poções francamente erosiva. Esta ültima zo na erosiva é claramente mostrada pela variação de forma do Baixo Espadarte nas cartas de 1960 e 1973. 
Em sintese podemos dizer que a sedimentação na ārea de estú do mantēm um padrão de evolução que migra de SE para NW.Assim sen do, o Canal de Tapari é uma zona de passagem de sedimentos; com tendência a mánter suas profundidades atravēs do tempo, havendo po. rém, um deslocamento contínuo da sua faixa de maiores profundidades no sentido SE-NW. O canal dos Poções jä apresenta certas cá racteristicas. predominantes de sedimemtação, porëm, ainda uma certa tendência à migração é observada no sentido $S-N$.

A migração da faixa de maiores profundidades do canal de Tá pari teria sido de cerca de $200 \mathrm{~m}$ em 12 anos, com taxa de migração em torno de $16 \mathrm{~m} /$ ano.

Uma ressalva deve ser feita, quanto às tendências aqui expos tas, no sentido de que o padrão mencionado refere-se ao período de tempo observado e que influências antrópicas, como desmatamen to, construção de barragens e exploração intensiva ao longo dos rios que fazem parte do Complexo Tocantins - Amazonas, especial mente o Tocantins, podem trazer modificações no meio natural de módo a modificâr as taxás de sedimentação ná áreà de sua foz.

A partir dos estudos efetuados na Ilha dos Guarás e adjacên cias, pode-se concluir que as características geológicas e sedi mentolögicas da ārea evidenciam úm ambiente instável, com altas taxas de deposição e erosão, alēm de predominante tendência de crescimento da linha de costa, particularmente no sentido SE-NW.

Dessa forma, haverā um decréscimo de profundidades, próximo à linha da costa, enquanto que na borda oposta (NW) do Canal de Tapari haverá erosão, de modo a acarretar um deslocamento da faixa de maiores profundidades efetivas do canal, embora estas possam se manter aproximadamente as mesmas, tal como vem acontecendo nas ūitimas dēcadas.

No que se refere à instalação e operação de um terminal por tuário, a manutenção natural das profundidades mäximas do Canal de Tapari (em torno de $20-25 \mathrm{~m}$ ) representa uma característica fa vorävel; entretanto, os deslocamentos consideravelmente elevados da linha de costa $(7 \mathrm{~m} / \mathrm{ano})$ e da faixa de maiores profundidades do canal (16 m/ano) constituem condições desfavoráveis, sob o ponto de vista sedimentológico. Levando em conta o grande volume de ma terial transportado, este problema não pode ser contornado de mo 
do econômico e permanente, o que aconselha a buscar-se um sítio de melhores condições naturais. 


\section{CAPITULO IV}

PORTOS E TERMINAIS EM BAIAS: OS CASOS DE SEPETIBA, ESTADO DO RIO DE JANEIRO, ARATU E ENSEADA DOS TAINHEIROS, ESTADO DA BAHIA.

\section{APRESENTAÇÃO}

Nota PENTEADO $(1970, p .22)$ que faltam à costa brasileira"re cortes pronunciados (baías e golfos) que tão bem caracterizam os litorais da Europa e da América do Norte... Faltam os ancoradouros naturais, onde o homem encontra abrigo seguro: os casos dos por tos do Rio de Janeiro e Salvador são verdadeiramente excepcionais no Brasil". E possível que a esses dois sitios portuārios, de gê nese fortemente condicionada por fatores tectônicos, se venha a acrescentar umas poucas baías com menores profundidades e condi Ções de abrigo, de origem mais diretamente ligada a processos se dimentares costeiros, como è o caso de Sepetiba. Esta baía, eduas feições subordinadas à Baía de Todos os Santos, serão objeto des te capitulio.

Tivemos a ocasião de estudar a Baĩa de Sepetiba em 1974/75, apresentando os resultados obtidos em dissertação de mestrado PON ÇANO, 1976a), parcialmente publicados (PONÇANO et a $i$ i 1976 e 1979). Aqui serão eles novamente abordados, a fim de compor o corpo do presente trabalho segundo os objetivos expostos no primeiro capi tulo.

Os căsos de Aratu e Enseada dos Tainheiros são mais limita dos, comparativamente a Sepetiba. Entretanto, é possível que ve nhamos a reconhecer alguns pontos comuns a todos.

\section{BAIA DE SEPETTBA}

O aproveitamento da Baía de Sepetiba colocou-se como alter nativa natural à expansão do Porto do Rio de Janeiro, abarcando am bos a mesma zona de influência, qual seja, os estados do Rio de Janeiro e Minas Gerais (PORTOBRAS, 1979). Previa-se duas fases de obras: na primeira seria implantado um terminal para importaçãode carvão a granel, alumina e outros granēis, num total de $5,8 \times 10^{6}$ toneladas anuais, com possibilidade de ampliação para $8,6 \times 10^{6}$ to neladas anuais. Na segunda seria instalado um terminal para expor tação de minērio de ferro da ordem de $6 \times 10^{6}$ toneladas anuais. A 
planicie costeira de Itaguaí seria usada para inștalação do retro porto. Quando realizamos este trabalho, já estava em operação um terminal da MBri-Minerações Brasileiras Reunidas S.A. instalado na i. Tha Guaiba.

Procuramos, ao final das investigações, apontar as princi pais caracteristicas e tendências da sedimentação da baía, buscan do indicar regiões mais sujeitas a erosão e assoreamento. Nessa época pudemos estabelecer de modo mais claro algumas linhas de in vestigação, comentadas no CAPÍTuLo 2, que julgamos ainda produti vas.

\section{A. Resultados Obtidos}

A Baía de Sepetiba tem cerca de $305 \mathrm{~km}^{2}$ de superficie, apre sentando por limites norte e leste o continente, a Restinga da Ma rambaia a sul, e a oeste un cordão de ilhas. Essa feição teria si do implantada em um paleovale escavado durante o ủltimo rebaixa mento gläciomeustätico de nỉvel marinho, de tal sorte que a res tinga seria uma feição pelicular, desenvolvida sobre um antigo interflüvio, cujo fechamento teria sido completado após a Trans gressão Flandriana.

Ao mencionado paleovale corresponde o canal com 10-15 m de profundidade que passa dentre as i.lhas de Itacuruçá e Jaguanum a tingindo o interior da baía; esse canal apresenta poçöes que ultra passam em pouco a curva batimétrica de $20 \mathrm{~m}$, indicando que as an tigas linhas de drenagem vêm sendo colmatadas por sedimentos atuais.

Foram coletadas 273 amostras de superficie de fundo (FIGURA

15) caracterizadas quanto a sua textura e mineralogia.

Em vārias dessas amostras forma observadas, quando de sua coleta, pelotas de argila centimétricas, constituídas de material muito coesivo, por vezes incrustado de areia e grânulos. ocorrem associadas ao canal acima mencionado, e acredita-se que tenham se originado por erosão de sedimentos pré-atuais (de possível idade Riss-W(urm) ai expostos.

o diâmetro médio dos sedimentos coletados foi usado tanto na caracterização faciológica quanto como parâmetro indicativo das energias envolvidas nos processos deposicionais (FIGURA 16). Sua distribuição indica dois setores principais na ărea amostrada, grosso modo separados pelo cordão de ilha situado no limite oes 


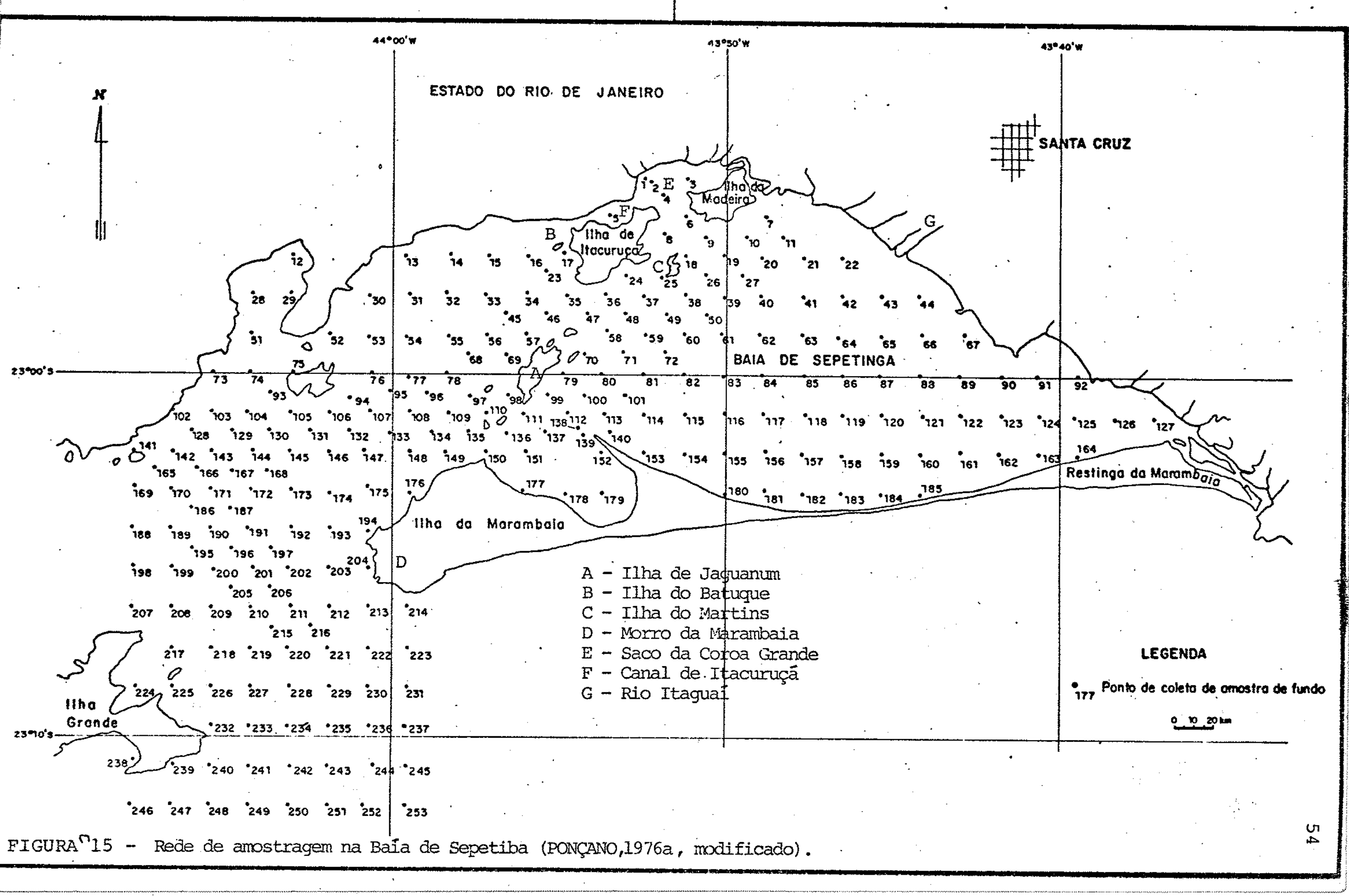




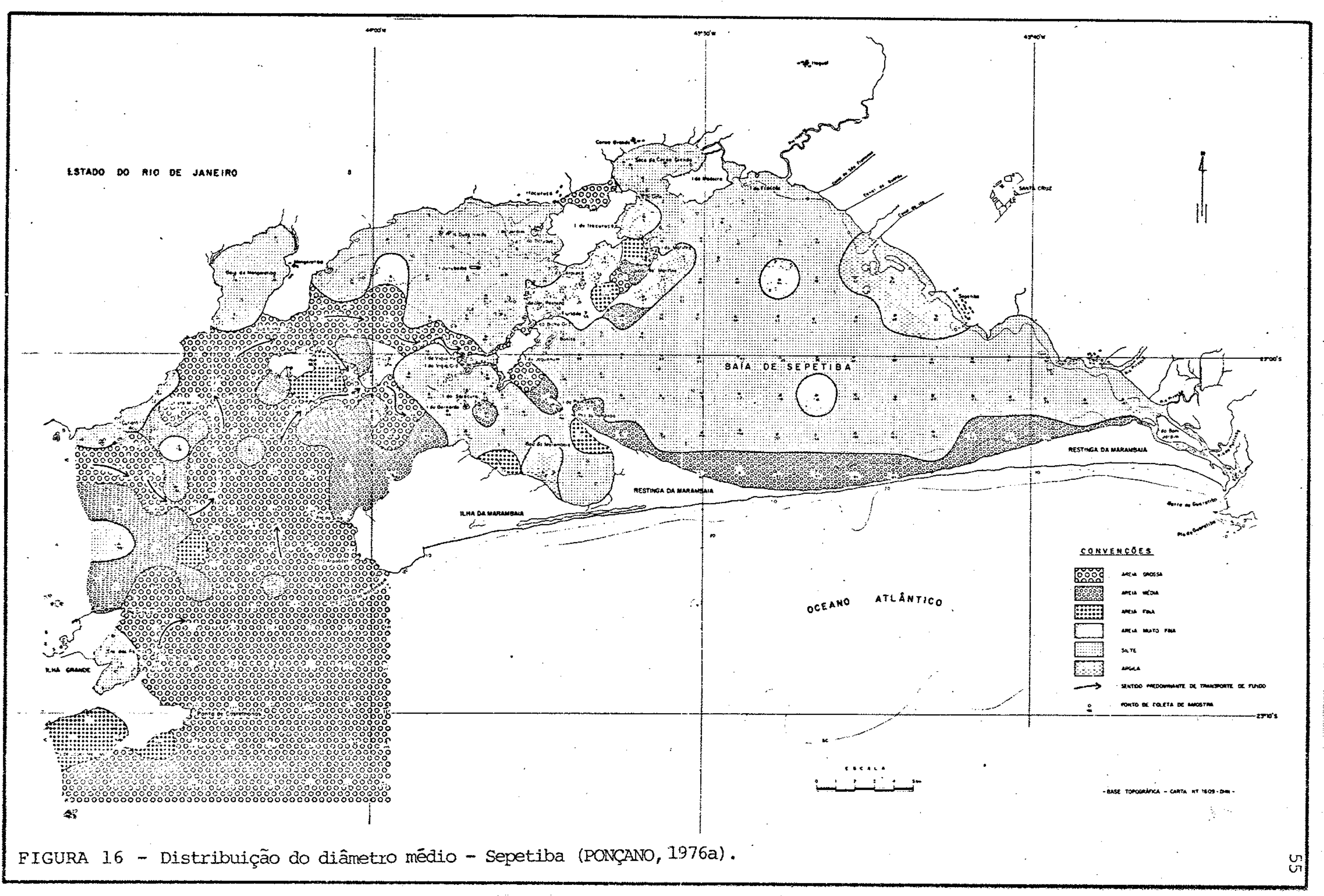


te da baía: um de circulação francamente marinha, indicado por areias grossas, e outro correspondente à baia propriamente dita, caracterizado por siltes, areias mëdias a muito finas e argilas.o limite entre os dois setores é abrupto, e o padrão faciolögico, visto com mais detalhe, sugere passagem de sedimentos de fundo em canais estreitos, entre o cordão de ilhas, de um para outro setor.

A distribuição do desvio-padrão indica predominância de se dimentos pobremente a muito pobremente selecionados, com uma ex pressiva mancha de sedimentos moderamente selecionados (FIGURA 17). Estas caracteristicas são atribuídas a retrabalhamento de ma terial prévio pobremente selecionado da plataforma. Pode-se acres centar que a seleção é pior no interior da baja, onde hä, ademais, contribuição direta de origem fluvial.

A assimetria foi interpretada no sentido de associar faixas de assimetria negativa a zonas de passagem de correntes de fundo; estas correntes removeriam o material mais fino, o que resultaria em distribuições granulométricas com caudas na fração grossa(FIGU RA 18).

Similarmente, para a curtose, considerou-se que as curvas leptocūrticas e muito leptocūrticas indicariam faixas de atuação de correntes de fundo (FIGURA 19).

- Os padrões de circulação de sedimentos estabelecidos por es ses parâmetros foram complementados pela anālise da distribuição do diâmetro médio da fração areia, porcentagem de argila, razão grânulo + areia/silte + argila e porcentagem de grânulos.

Adicionalmente, foi analisada a distribuição de teores em matēria orgânica, visando a delimitar áreas mais e menos oxigena das, correspondentes a zonas de maior e menor movimentação de sedí mentos. Os resultados obtidos foram bastante próximos dos indica dos pelas caracteristicas texțurais.

Identificação de minerais pesados foi efetuada em 74 amos tras, em āreas descontínuas no interior e fora da baía. Uma anāli se em planta das distribuições de andaluzita, epídoto e anfibólio indicou alguns aspectos dinâmicos, tais como zonas de maior movi mentação de sedimentos e eddies, estes ültimos sugeridos também por dados texturais.

As assembléias mineralögicas de 55 dessas 75 amostras foram 


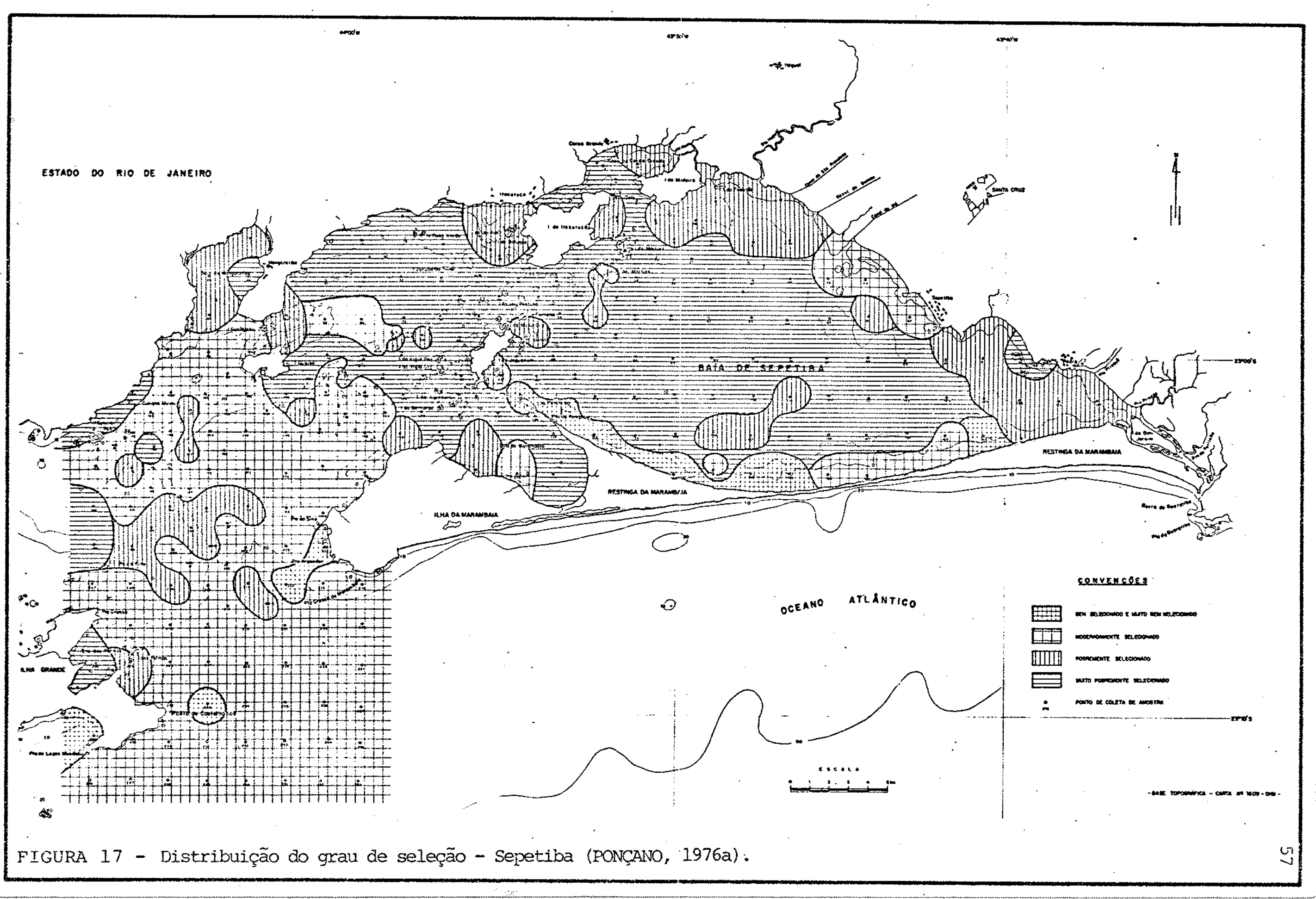




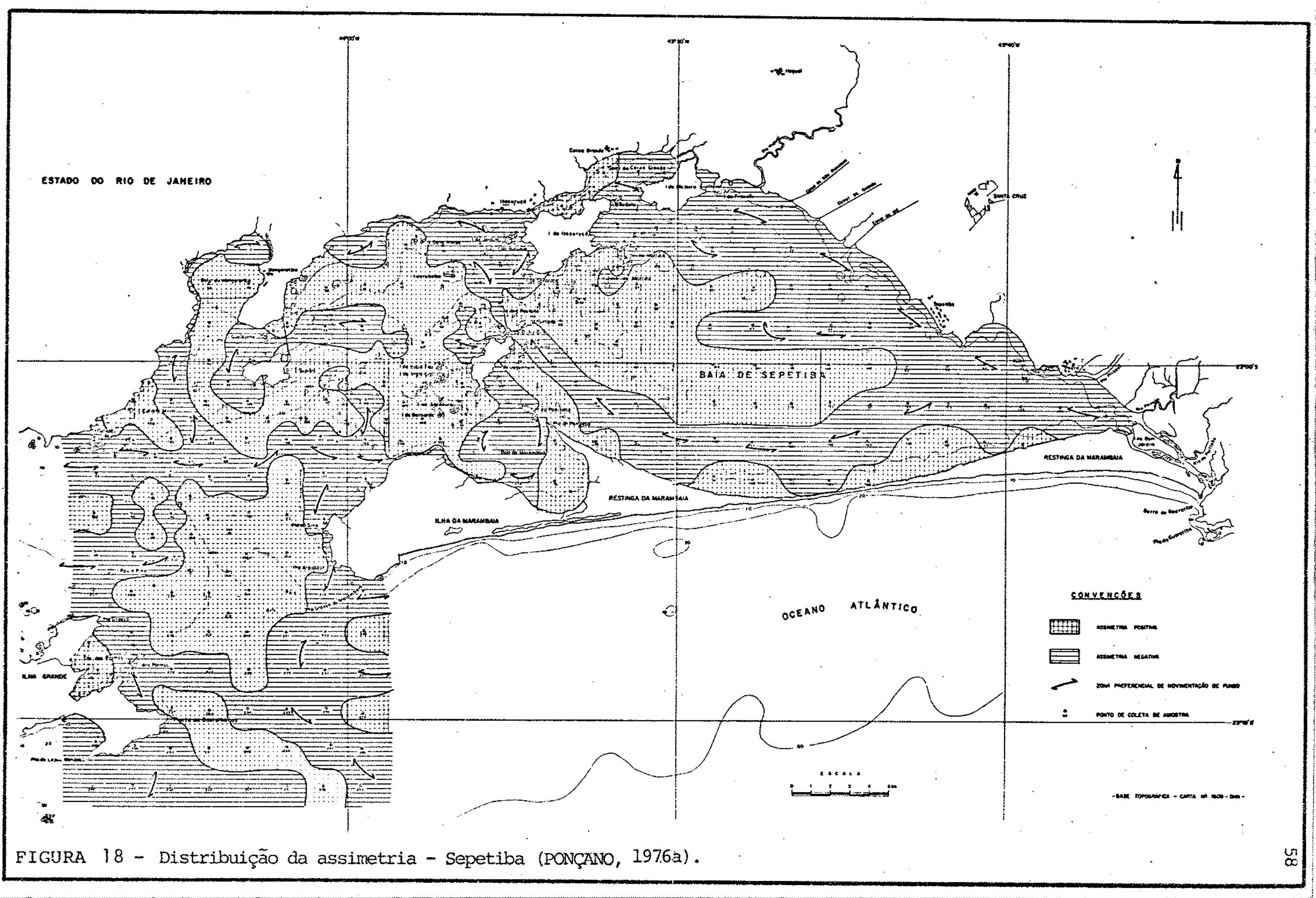




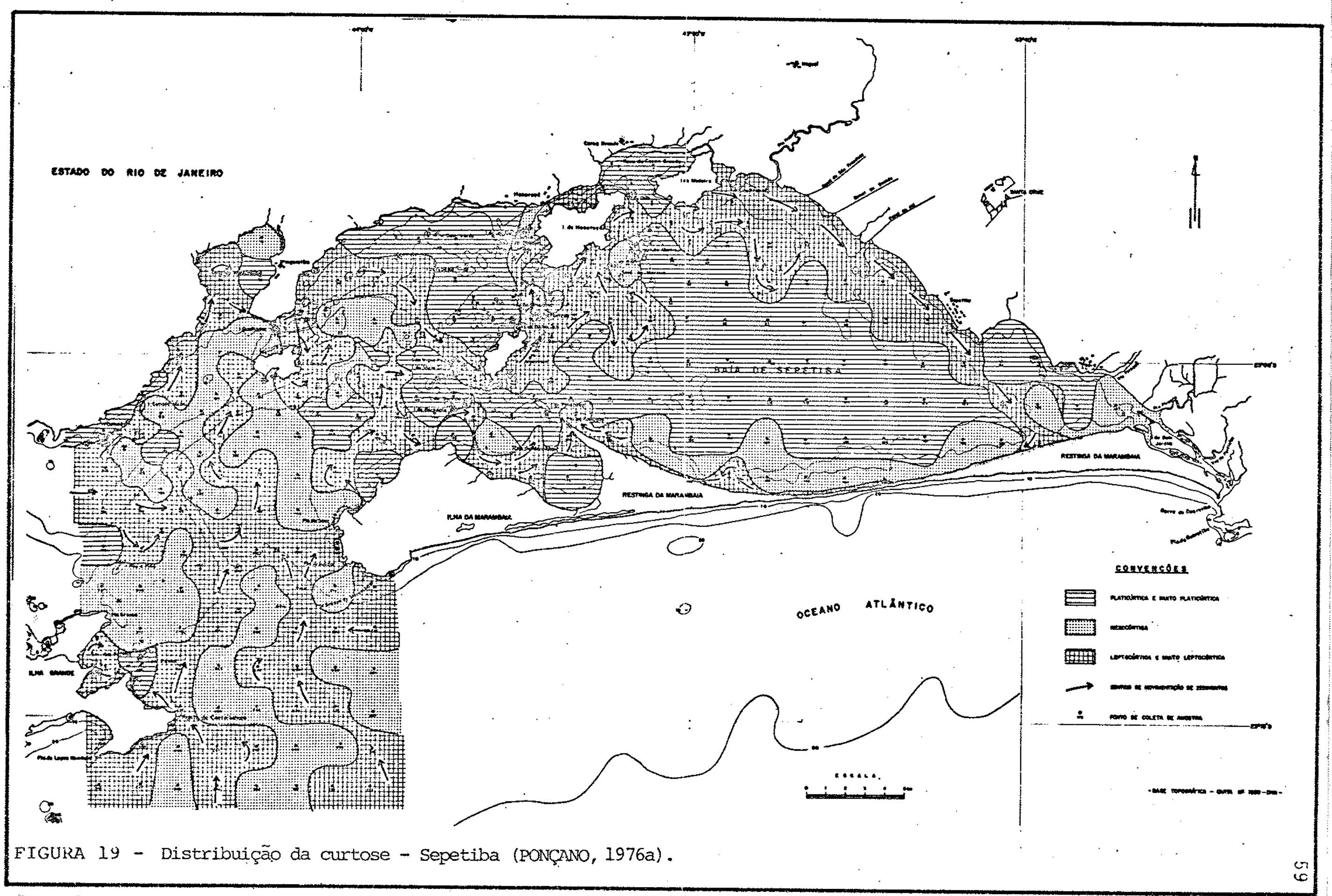


ainda tratadas por anālise de agrupamento, cujos resultados indicarari grande similaridade entre as amostras internas e externas à baía. Não obstante, a distribuição em planta dos diferentes grupos de amostras, sugere localmente movimentação de sedimentos concor dante com a obtida por anālise textural.

Concluímos então, atravēs dos dađos batimëtricos, granulomé tricos e petrográficos, existirem três fontes oceânicas princi pais para os sedimentos que adentram a Baía de sepetiba (PONÇANO, 1976, p.38-39): a primeira, "e menos expressiva, formada pelos ca nais da barra de Guaratiba que possibilitam maior aeração e movi mentação na face interna da Restinga da Marambaia. A segunda, em ordem de importância, constituída pela região situada entre a I lha Grande e o Morro da Marambaia. A terceira, e mais importante, pro veniente da baía de I lha Grande".

"Os sedimentos provenientes da segunda e terceira áreas-fon tes juntam-se ao entrar na Baĩa de sepetiba, e sua circulação sé faz pelas seguintes passagens: entre as ilhas de Itacuruçá e Ja guanum, entre o Morro de Marambaia e a Ilha de Jaguanum, e entre as ilhas do Batuque e Itacuruçä, seguindo pelo Canal de Itacuruçá, desembocando no Saco da Coroa Grande".

"O fluxo proveniente da barra de Guaratiba junta-se à ärea de movimentação entre o Morro da Marambaia e Ilha de Jaguanum".

"A partir dessas entradas, em especial as do setor oeste da Baía de Sepetiba, formam-se frentes progradacionais que tendem a colmatar a baía. Mecanismos de circulação local, eddies em espe cial, podem originar depósitos locais significativos".

"A contribuição de detritos de origem continental fluvial é bastante limitạ̣a na Baía de Sepetiba, ficando sua influência res trita a uma faixa colocada a nordeste da Baí, nas proximidades das desembocaduras de canais e rios".

"Tanto os processos de circulação de correntes, quanto os de sedimentação, mostram então que a baía de sepetiba é uma ärea de caracteristicas predominantemente marinhás, provavelmente pela energia das correntes envolvidas e pelo próprio tamanho da baía.

"A energia dos processos de circulação é bem mostrada pela distribuição dos diâmetros médios da fração areia, dos grânulos, bem como do diâmetro médio da amostra total". 
"A distribuição dos diâmetros médios da amostra total mostra que o sedimento mais representativo do fundo da Baía de Sepetiba é - silte, seguido de areia e argila. A fração argilosa é especialmen te importante na faixa de influência de processos fluviais".

"Mercê da intensa movimentação de que é seđe, a Baia de Se petiba apresenta boa aeração, não se esboçando ambiente euxinico senão em parte de sua metade leste".

Do ponto de vista da implantação de terminais portuários, en tendemos à época (PONÇANo, 1976a, p.39-40) que, em termos geológi cos a Baía de sepetiba se caracterizava como "bacia semi-confinada, em fase de assoreamento. Esse prognóstico não é porēm significativo em termos da implantação de instalações portuárias, que deve ser analisada com auxilio de elementos cambiáveis em periodos de tempo relativamente curtos em relação à evolução geológica".

"Nesse sẹtido, a comparação de cartas batimētricas defasa das de cerca de um sēculo mostrou que há nítida tendência de apró fundamento no setor oeste da Baía de Sepetiba, especialmente nas proximidades das ilhas de Itacuruçā e Jaguanum. Essa tendência po de manter-se, e a situação pode ainda evoluir no sentido de haver um maior equilíbrio erosão/deposição. A hipötese contrāria, qual seja, tendência ao predomínio da deposição sobre a erosão nessas áreas, não deve ser esperada como provāvel, dadas as altas ener gias de transporte de fundo que aí ocorrem, anteriormente menciona das".

"Hã então uma convergência dos elementos analíticos sedimentológicos e topográficos que caracterizam o setor oeste da Baía de Sepetiba como local de circulação ativa, na qual não são esperados problemas de colmatagem generalizada em tempos históricos, mantidas as atuais extensões e modos de ocupação. humana da área estudada".

"Os processos de sedimentação e a compartimentação batimētri ca da Baía de sepetiba permitem fazer as recomendações que se se guem, quanto à sua utilização para instalações portuárias".

"O setor da Baía de sepetiba que reúne as melhores condições de calado, de movimentação de sedimentos, e de aeração situa-se num polígono limitado grosso modo por uma linha norte-sul que passa pela desembocadura do Rio Itaguaí, por uma linha leste-oeste que 
passa pela extremidade norte do Morro da Marambaia, e pelo cordão de ilhas que forma o limite oeste da bafa".

"Na ärea acima definida, a situação que se configura mais favorävel ao estabelecimento de canais de acesso está entre as ilhas de Itacuruça e Jaguanum".

"Da Ilha de Itacuruçã em direção às ilhas do Martins e da Marambaia, hā um decréscimo gradual de energia".

"Nas proximidades da Ilha da Madeira hã uma zona de “transí ção entre uma zona de processos essencialmente marinhos e outra de influência fluvial, sendo esta última uma zona de franca depo sição".

"Dependendo então do projeto das instalações portuárias, po de-se fazer a opção entre uma ārea que venha apresentar eventuais problemas de erosão e outrá de deposição, existindo transição en tre ambas".

"Seguindo a orientação acima exposta, pode-se obter mais pormenores referentes a problemas locais e especificos de ero são/deposição, tais como eddies bem como a caracterização dos se dimentos de fundo, a partir dos vários elementos analiticos contí dos neste trabalho, ficando claro porëm, que muitas das respostas quantitativas necessárias a nível de projeto deverão ser investigadas por outros estudos, em especial por medição direta".

\section{BAIA DE ARATU E ENSEADA DOS TAINHEIROS}

o estudo de ampliação e revitalização do sistema de transpor te hidroviário urbano da região metropolitana de salvador é parte do objetivo do Ministério dos Transportes de incrementar no Brasil a utilização dos meios de transporte de massa.

Nessa região desenvolveu-se amplo programa de pesquisa apli cada, abrangendo desłe a:s roddiçöes do meio físico, até a projeção de frotas e sistemas tarifários, sob os auspícios da Empresa Brasi leira de Transportes Urbanos-EBTU. Integrando esse programa proce demos, em 1980 ao estudo da movimentação de sedimentos, atravēs da investigação de duas āreas. A primeira abrange a Enseada dos Tai inheiros, onde se encontra o estaleiro de reparos da Companhia de Navegação Baiana; a segunda interessa um setor da Baía de Aratu,on de seria instalado um terminal de passageiros (FIGURA 20). 


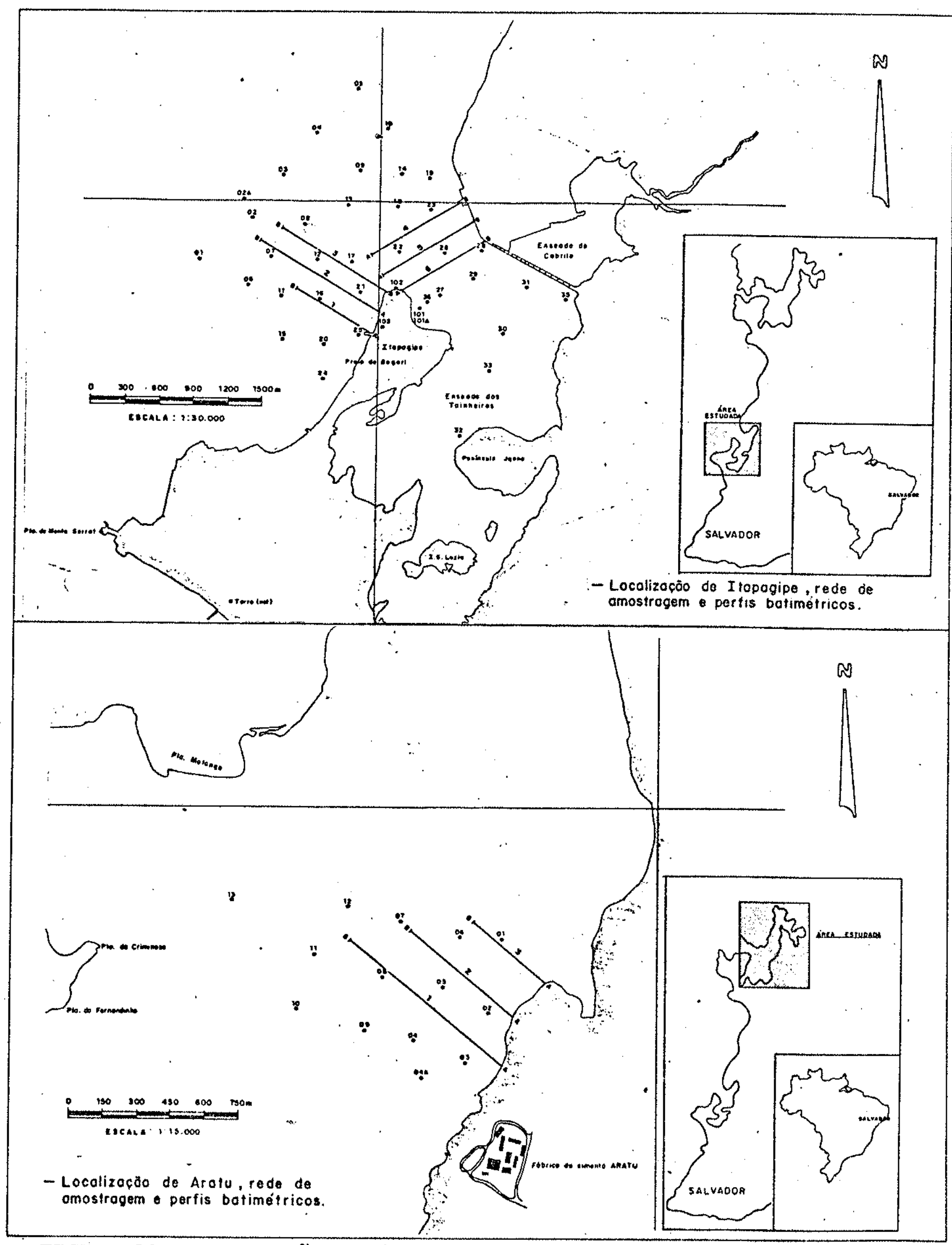

FIGURA 20 - Iocalização das áreas de estudo e redes de amostragem - Itapagi. pe e Aratu. 
Procuramos realizar uma integração de dados de caracter re gional e local, visando a detectar elementos de grande e pequena ordens que pudessem ser aplicados ao caso em questão:

A. Aspectos da ocupação das Areas de Interesse

Uma consulta às coleções de cartas näuticas disponiveis mos trou variações de fundo de magnitudes inaceitäveis, possivelmente por mudança do nivel de referência. Consultas feitas a entidades competentes não permitiram esclarecer o assunto, pelo que decidimos não utilizar esse tipo de anälise. Entretanto, visando obter dacos históricos sobre as variações no regime sedimentar, procede mos a pesquisa sobre aspectos da ocupação humana ligados à Baía do Aratu e à Enseada dos Tainheiros.

Tanto a área de Aratu quanto a de Itapagipe têm uma histooria de ocupação intimamente condicionada pela própria história de Sal vador. Itapagipe, especialmente, por abrigar bairros importantes da capital (Penha e Mares).

Salvador foi durante três séculos a aglomeração urbana mais importante e populosa do Brasil. Sua função portuāria existiu des de o início da vida urbana, gerada desde sua fundação pelas reco mendações da escolha do local, para se erigir uma "fortaleza for te: mais para dentro da baia, sitio sadio e de bons ares, com abundância d'ägua e condições favoráveis de porto" (AZEVEDO, 1960).

Não foram evidentemente encontradas condições favoräveis à implantação de grande porto na enseada dos Tainheiros, pois, em bora não distante da entrada da Baía de Todos os Santos e abriga da dos ventos do sul, o banco de Itapagipe, na entrada da ensea da, sempre limitou o calado das embarcações. A Baía de Aratu, por outro lado, encontrava-se demasiadamente distante. Em Itapagipe, com efeito, sucessivos requerimentos de concessão para exploração de docas foram negados em 1841 (Biober e Cia., com vistas à nave gação) e em 1865 (Companhia Baiana, com vistas à implantação de projetos "de um dique a mortona no desarmado e abandonado propug nāculo, destinado não só ao conserto das duas embarcações, como tambēm para auxilio e utilidade do comērcio e navegação em ge ral)" pelo governo imperial, apoiado no fato de haver pouca pro fundidade d'ägua, como uma das justificativas (CAMPOS, 1940). Es te autor refere-se ao fato, historiando o antigo forte de são Bar 
tolomeu de Itapagipe, e complementa tais justificativas com

existência de "vetígios de antiga mortona, abandonada por se ha ver construido em terreno pouco sólido".

Assim, as condições favoräveis foram realmente encontradas onde hoje o porto se situa. Este local oferece não sö profundida des que permitem a atracação de navios de grande calado, como apresenta abrigo dos ventos que sopram do lado oriental de $\mathrm{N}$ atē SSE.

Nos anos recentes, o Porto de Salvador vai perdendo sua im portância. Segundo MESQUITA (1977) seu movimento portuário vem de crescendo nos ültimos anos, em consequência da implantação do Porto de Madre de Deus, terminal maritímo da PETROBRÁs.

Porém, se o porto ficou ali localizado. Itapagipe não dei xou de ter relativa importancia para salvador. Com efeito, por ser caminho de comunicação do porto com o interior, representava ārea militarmente estratēgica.

Já em 1638, pequenas fortificações ou trincheiras que guar aavam um lado e outro da entrada da Bara de Itapagipe, foran toma das pelos holandeses. Apōs sua expulsão, foi construído o forte de são Bartolomeu da Passagem de Itapagipe. Nesse início do sécu lo XVII, além das fortificações e da ocupação da área por pescado res, relata-se que "entre a cidade e a península de Itapagipe ha via um engenho e na peninsula os currais de Garcia D'Ávila e tam bëm nela já se punham na praia, navios a seco para consertä-los" (GORDILHO, 1960). Com efeito, segundo COSTA, (1960) o forte tam bém representava uma. "sentinela a guardar os navios que iam querenar (ser restaurados) esteiro adentro". Ainda segundo o mes mo autor, apös ter sido devastado para uso de seu material de construção, foi condenado em 1843 e arrasado em 1903.

o desenvolvimento de Salvador interrompe-se no sēculo XIX, resultado do déslocamento da economia nacional para o sul. A capital baiana viveu então un periodo de grande estagnação e crescimento lento. Essa situação só mudiou a partir de 1940 . No inicio deste sëculo, Itapagipe não era mais que uma "para gem assaz pitoresca e delejtāvel, não só em virtude das muitas fazendas e casas de recreio que bordavam a praia, como também pelas muitas ilhotas, que pontilhavam o estuário" no dizer de VILHENA $(1921$, in Campos, 1940).E conclui, assinalando que "do lado do sul , 
por fim, ficavam inúmeras roças, maiores ou menores, em terreno plano arenoso e alagađiço".

A partir de 1940 dä-se portanto, o crescimento recente de Salvador com repercussões importantes em Itapagipe e Aratu. Embo ra o crescimento não tenha sido homogêneo, dadas as condições do sitio, a cidade avançou sobretudo para $\mathrm{N}$ e $\mathrm{NE}$, em direção portanto a Itapagipe.

Para uma visão de conjunto da periferia de Salvador; CARVẸ IHO (1960) define, entre outros setores, o setor ferroviário de plataforma (são Brás, margem direita da enseada) até Candeias. Es te setor passa a ser ocupado por apresentar ligação não só. cons tante e garantida com salvador, através da ferrovia, mas também por se tratar de ārea onde a moradia é relativamente mais barata. Não só este setor periférico, mas tambēm os bairros de Penha e Ma res passam a ter uma função residencial. Acresce-se a esta função, uma função industrial marcada pela vocação daqueles bairros, Penha e Mares, onde se localizavam nos anos 40, 25 fäbricas cujos operärios residiam em sua maioria em Itapagipe. Assinala SANTOS (1959) que, embora a histōria urbana de salvador tenha conduzido à concentração das funções vitais do Estado no centro da cidade, constitui exceção o parque inđustrial, embora muito pequeno, ins talado naqueles bairros e periferia.

Segundo SANTOS (1959) "a chegada de milhares e milhares de novos emigrantes (impelidos pela seca no sertão) não somente pro vocou a extensão das superficies construídas, como soluções herói cas (invasões) como a de Itapagipe na enseada dos Tainheiros".

Segundo CARVALHO (1960), Mares e Penha transformaram-se de zonas residenciais da classe humilde em zonas de classe mëdia, à medida que foi sendo instalada a infra-estrutura urbana. A ärea se valorizando, fez com que a população de baixa renda perdesse terreno, deslocando-se sobre a enseada em aterros de lixo, primei ro sobre os manguesais e depois sobre a enseada mesmo: - os Ala gados.

Este crescente aumento populacional da ārea, com construções sobre palafitas e aterros de lixo lançados na enseada levou àcria ção de um örgão responsāvel por esta área - AMESA - que no princí pio da década de 70 iniciou a coordenação dos estudos, projetos e execução das obras na região dos Alagados. Isto sistematizou a 
acelerou a aterragem e ocupação da Enseada dos Tainheiros, inicia da por volta de 1940.

Em 1961, na entrada da Enseada dos Tainheiros, iniciou-se a construção do cais de reparo e carreira da CNB, terminado em 1963. A Marina Yacht, fol implantada de 1973 a 1975, prōximo ao cais da CNB, porém localizada mais para fora da Enseada dos Tainheiros.

Já a ocupação da ārea de Aratu só agora tem aumentado sensi velmente, com a instalação de um centro industrial em sua perife ria. E o caso da fäbrica de cimento Aratu, ao lado de uma das āreas aqui apresentadas.

Considerando-se os aspectos da ocupação das āreas objeto de estudo, podemos destacar o seguinte:

- A ārea de Itapagipe apresenta problemas de sedimentação que limitaram sua ocupação desde o início do século XVII.

- A partir de 1940 a ocupação desta ārea se dã de forma mais intensa, deslocando-se sobre a enseada em aterros de iixos e palafitas.

- No início da dēcada de 70 foram aceleradas e sistematiza das a aterragem e ocupação da Enseada dos Tainheiros.

- A ocupação da ärea de Aratu tem aumentado com ainstalação de um parque industrial nesta região, sem reflexos notá veis nos processos de sedimentação.

B. Caracteristicas da Sedimentação Atual na Baía de Todos os Santos

Ao desenvolvermos este trabaiho, em 1980, as principais ca racteristicas dos sedimentos de superficie de fundo da Baia de Tô dos os Santos haviam sido apresentadas por BITTENCOURT et ali (1976), que nela distinguiram 4 fácies principais: areia quartzosa, de lama, de biodetritos e mista (FIGURA 21). Os sedimentos de fä cies lama seriam atuais, enquanto que os da fácies mista e de bió detritos seriam do tipo palimpsesto. Isto se deveria a uma história evolutiva em que, durante a última fase de rebaixamento do nivel marinho, hä cerca de 15000 anos, a região que hoje é a Baía de Todos os Santos, teria recebido sedimentos continentais fluviais, com a transgressão subsequente, os clāsticos grossos teriam se con centrado nas linhas de costa sucessivas, originando os depósitos correspondentes à facies areia quartzosa, que são características do canal que se situa entre a Ilha de Itaparica e Salvador. Ao fi 


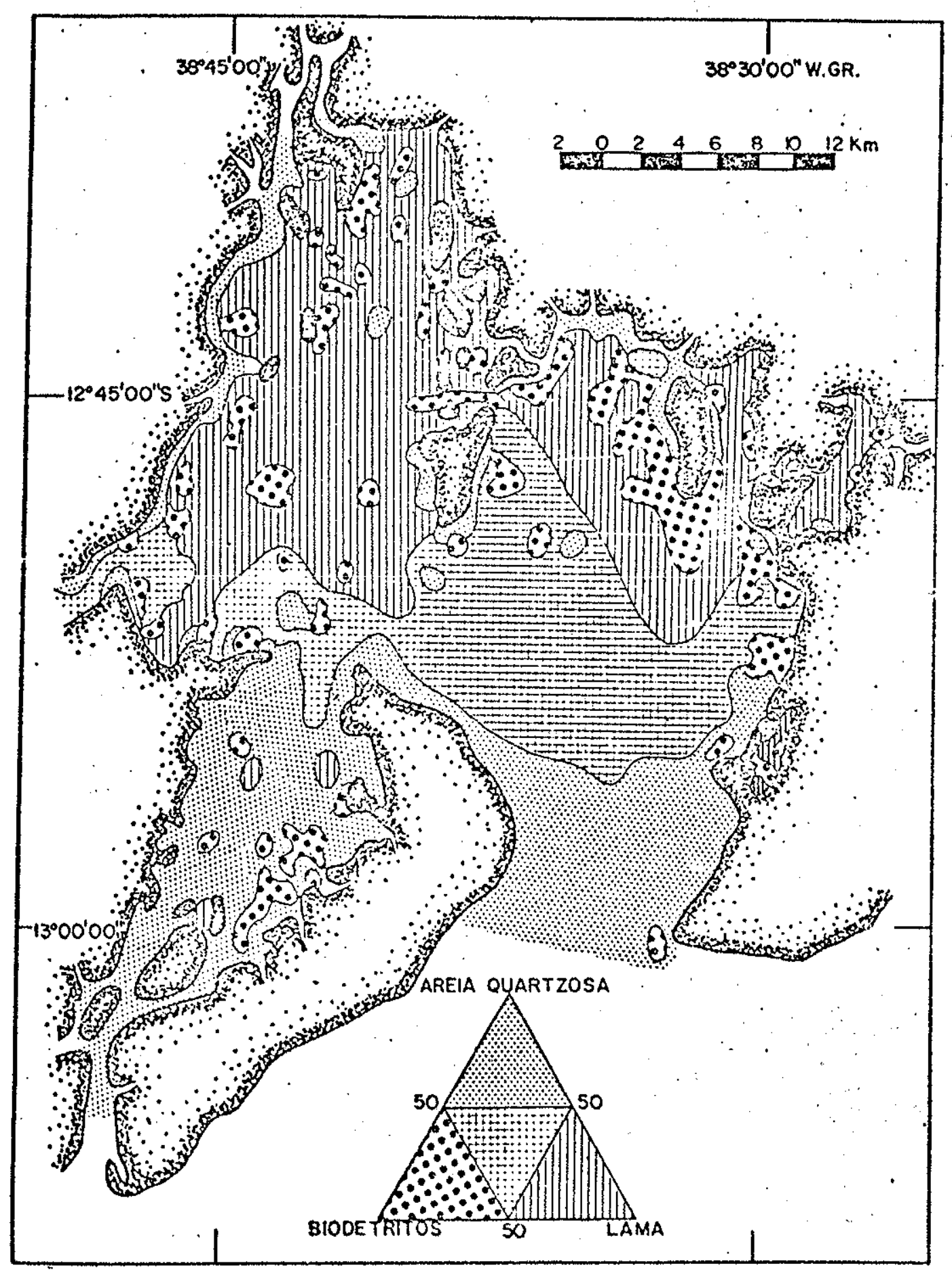

FIGURA 21 - Distriöouição das fácies sedimentares na Baja de Todos os Santos (BITJENCOURT et ali $i$, 1976). 
nal da Transgressão Flandriana teriam se formado os depósitos con chîferos. Sedimentação argilo-siltosa (fácies lama) teria entãoti do início, prosseguindo até hoje.

Essa caracterização faciolögica foi complementada pela des crição dos argilominerais dos sedimentos de fundo, feita porVILAS BOAS \& BITTENCOURT (1979), que distinguiram três regiões princí pais: uma caracteristica da foz do Rio Paraguaçu (predomínio de caolinita e montmorilonita, ilita subordinada), outra abrangendo - terço mais setentrional da baía (predominio de caolinita e ili ta, montmorilonita subordinada) que estaria relacionada à alteração de rochas do Supergrupo Bahia ajacentes, e uma terceira,abran gendo a região do canal entre a Ilha de Itaparica e salvador, do Canal de Itaparica, e algumas porções no interior da baỉa.Esta ül tima representaria região de aporte e movimentação de sedimentos provenientes da costa, trazidos pela Corrente do Brasil.

Entretanto, levamos em conta a observação de BITTENCOURT et alii (1976; p.248) de que as "condições hidrológicas no interior da baía são pouco conhecidas, principalmente no que se refere ao padrão de circulação... Durante a maior parte do ano a Corrente dó Brasil flui paralelamente à costa, no sentido sudoeste, penetrando na baía, nos meses de junho e julho, com uma velocidade média, medida na superficie, de 0,6 nö...". Para trazer elementos adicio nais visando a elucidar essa questão, lançamos não de imagens IAND. SAT, cincidentemente as correspondentes a uma tomada de 26 de julho de 1973, possivelmente a ünica existente com boas condições de cobex tura de nuvens.

Procedemos então à anālise de imagens 1:1 000 000" dos canais 4, 5 e 7, de acordo com metodologia empregada previamente (PON ÇANO, 1976b; HERZ, 1979, VILLAGRA et ali $i, 1980)$ : maior contraste solo/vegetação e ágúa è obtido no canal 7, enquanto que o canal 4 mostra situação de maior penetração de luz na ãgua, favorecenđo a detecção de dados de material em suspensão e mesmo batimētricos; os canais 5 e 6 são usados complementarmente. Parte-se ainda da premissa que os niveis de cinza das äguas são correlacionáveis à quantidade de sedimento em suspensão, numa escala qualitativa e relativa: quanto mais tendem ao cinza-claro, mais sedimentos por tam as āguas:

Podemos notar que a morfologia das manchas d'ägua mais car 
regadas de sedimentos em suspensão ē fortemente sugestiva de uma corrente costeira SW-NE no setor considerado da costa baiana (FI GURA 22).

O interior da Baía de Todos os Santos mostra a NW da Ilha de Itaparica uma forte influência de descargas fluviais, especial mente do Rio Paraguaçu.

Nota-se que hã aparentemente um canal de circulação associa do ao Paraguaçu, caracterizađo por pouco material em suspensão. Isto explica-se provavelmente por esse rio desaguar na pequena baía do Iguape, onde deve depositar parte de sua carga (AVANZo, 1980).

o setor leste da baīa, onde se situam as duas āreas de inte resse (Aratu e Itapagipe) não mostra, a este nível de anälise, in fluência fluvial marcante, estando sob influência principal da circulação d'ägua dominada pela penetração de um ramo da corrente costeira baía a dentro.

Cabe aqui ressaltar que as principais zonas de circulação no interior da baía estão associadas ao canal entre a Ilha de Ita parica e Salvador, e suas ramificações, em contexto batimëtrico dé prováveis paleovales, tal como tivemos ocasião de expor para o caso de Sepetiba.

Esses entalhes fluviais afogados, similarmente a outros lo cais da costa brasileira, vêm ainda hoje funcionando como zona pre. ferencial de circulação d'água como parece ser também o casọ do canal de maré ligado ao rio paraguaçu.

Nessa perspectiva, deve-se notar que não hä drenagens impor tantes associadas às duas āreas de interesse (Itapagipe e Aratu), onde esse tipo de controle de paleocanais não é tão evidente numa análise regional.

Apesar disso pode-se notar, a partir das cartas batimétricas, que essas feições se acham presentes em ambos os locais, sendo que no caso de Itapagipe a migração de sedimentos de fundo obliterou parte do canal, notando-se por esse motivo maiores profundidades no interior da enseada que em sua barra.

Esse modo de circulação d'ägua define tambëm algumas carac terísticas da deposição de sedimentos.

Assim, ao lado dos principais canais de circulação regional, delimitam-se zonas preferenciais de deposição, como se nota espe cialmente a norte do canal associado ao Rio paraguaçu, no Canal 


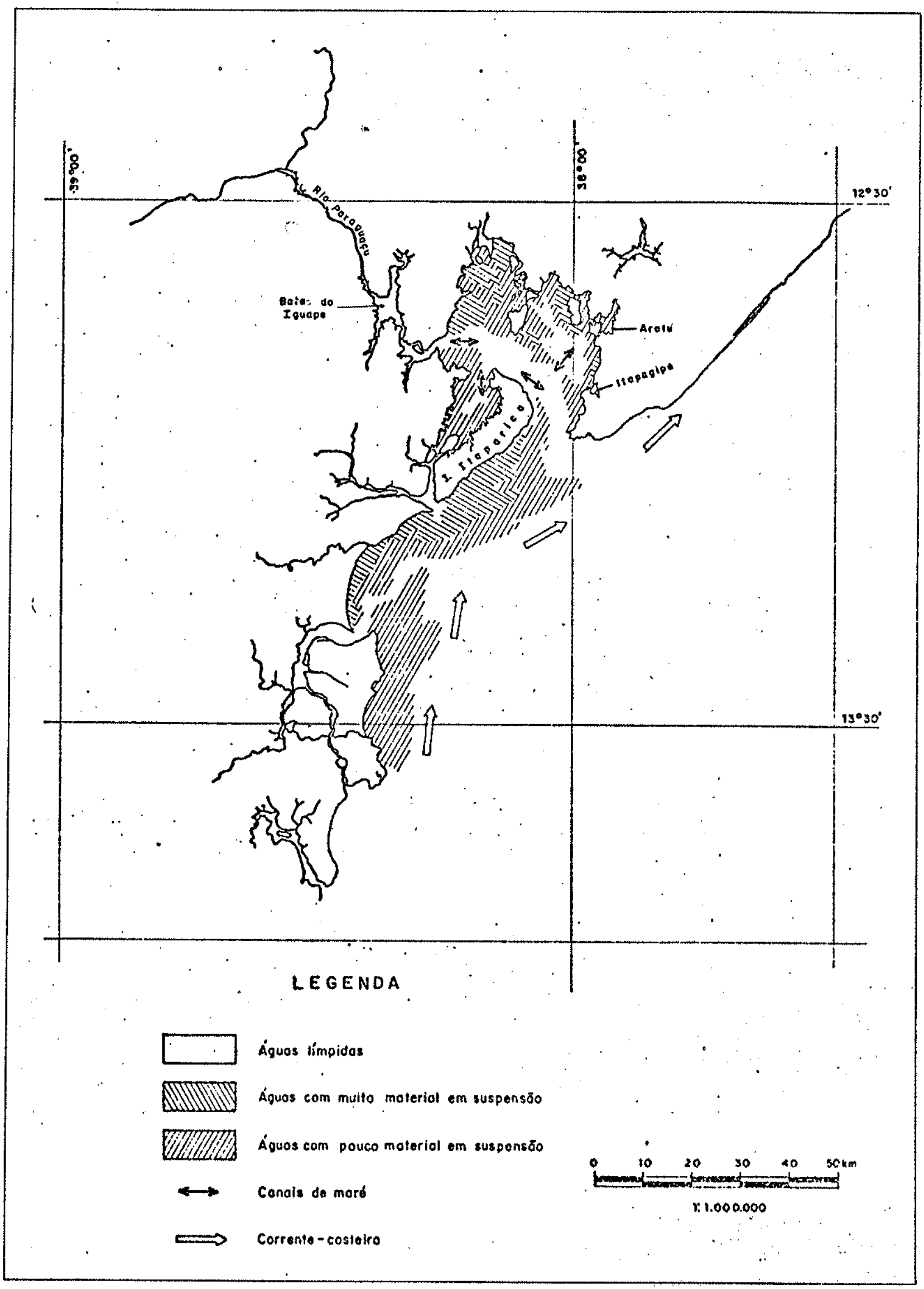

FIGURA 22 - Padrão regional de circulação d'água e sedimentos em suspensão, a partir de imagens LANDSAT. 
de Itaparica, e tambēm na zona leste da Baỉa de Todos os Santos.

De fato, esse padrão concorda com as fácies sedimentares dos sedimentos de fundo mostrada na FIGURA 21 , em que se nota forte predominância de sedimentos lamosos ou mistos nas áreas de deposi ção acima mencionadas, com exceção do Canal de Itaparica, cuja sí tuação não pudemos entender com os dados disponiveis.

No setor leste da baia, em que se situam as duas äreas de interesse, cabe notar que hä decréscimo da influência associada à corrente costeira, de sul para norte, ou seja, de Itapagipe para Aratu, que se reflete num aumento de sedimentos finos nesse mesmo sentido.

Tal diferenciação confere caracteristicas regionais distin tas para as duas āreas de interesse, caracterizando a de Aratu, co mo menos sujeita a modificações naturais, bruscas de sedimentação.

Não obstante a importância da descarga do Rio Paraguaçu (VI LAS BOAS \& BITTENCOURT, 1979), pode-se perceber que, similarmente ao caso de Sepetiba, o padrão de circulação d'águas e sedimentos è dada por componentes aceânicos, em concoraancia com a conciusão de WOLGEMUTH et alii (1981) de que a distribuição de salinidades na Baía de Todos os Santos mostra ser ela quase que inteiramente do minada por água do mar movimentada por corrente de maré. Ademais, verificaram que a carga sedimentar em suspensão do Rio Paraguaçu deposita-se quase que inteiramente antes de atingir o corpo princi pal da baîa, conforme sugeríamos acima.

Nesse sentido parece ser de fundamental importância as dimen sões da Baía de Todos os Santos, cuja superficie é de cerca de $800 \mathrm{~km}^{2}$ (BITTENCOURT et azii; 1976), a que podemos comparar sepe tiba, com cerca de $305 \mathrm{~km}^{2}$ (PONÇANo, $1976 \mathrm{a}$ ).

Resta entretanto uma divergência fundamental entre nossas observações e as de BITTENCOURT et ali $i(1976)$, no que diz respeito à corrente que carreia sedimentos da plataforma para o interiorda baía. Para aqueles autores, trata-se da corrente do Brasil, que flui paralela à costa no sentido sudeste. ora, o padrão de disper são dos sedimentos, nas imagens examinadas, indica sentido opos to. E possivel que tenhamos aqui uma corrente costeira, e não a Corrente do Brasil, oceânica, como fator principal da circulação de sedimentos e ăgua na Baía de Todos os Santos. 
Segundo SILVESTER $(1968,1974)$ o transporte litorâneo pode ser inferido a partir da morfologia de feições costeiras emersas tais como barras, cúspides, e forma de baías e enseadas. A partir da análise de cartas e outros documentos, para o mundo todo, chega esse autor a delinear o sentido do transporte ao longo da cos ta brasileira, que no caso do Estado da Bahia, seria N-S, conforme postularam BITTENCOURT et alii (1976). Entretanto, usamos os mesmos critérios de SILVESTER, e chegamos à conclusão oposta, pá ra o trecho da costa entre Itacaré e Salvador (FIGURA 23).

C. Caracteristicas da sedimentação atual na Enseada dos Tai nheiros

A evolução geomorfológica e secimentológica desta ārea foi caracterizada por VILAS BOAS \& NASCIMENTO, 1979. Dentre suas con clusões destacamos as seguintes:

a) Antes da deposição dos terraços arenosos ao sul e a oeste da Enseada dos Tainheiros, há 2600-3000 B.P., o mar ocupava toda a região de afloxamentos desses terraços; deixando emersas algumas ilhas constituidas desedimentos do Supergrupo Bahia. A partir do fechamento da enseada, iniciou-se a sedimentação argilosa que permanece até os dias atuais.

b) As enseadas dos Tainheiros e do Cabrito constituem um am biente restrito con energia extremamente baixa, onde se depositam atualmente sedimentos muitos finos transportados em suspensão uniforme. Os sedimentos grossos e inter mediărios que aî se encontram estão em desequilibrio com - ambiente, tendo sjdo, portanto, depositados em épocas passadas.

A faciologia dos sedimentos de superficie de fundo, conforme os estudos de VIIAS BOAS \& NASCIMENTO (1979) ë apresentada na FIGURA 24.

Realizamos amostragem cobrindo ārea algo diferente, abrangen do parte da Enseada dos Tainheiros e parte da baia, visando a esta belecer un padrão de circulação atual de sedimentos, visto as in formaçöes disponiveis darem conta de movimentação de areias nessa região. Os resultados obtidos para distribuição do diâmetro médio (FIGURA 25) são, no interior da enseada, essencialmente concordan 


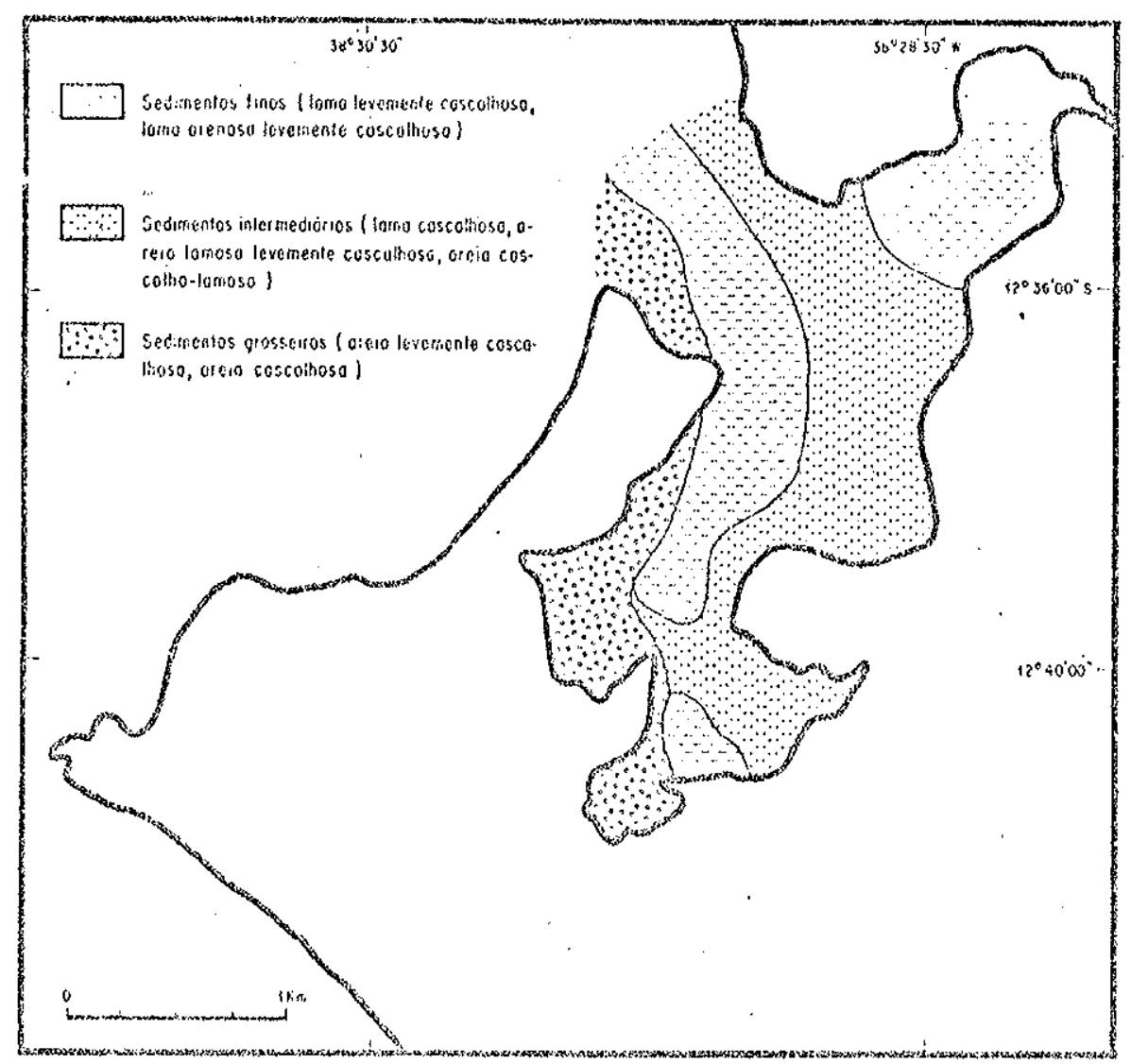

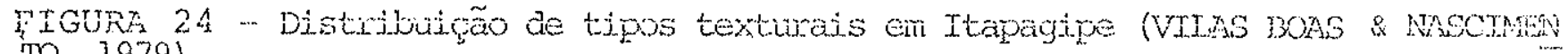
TO, 1979).

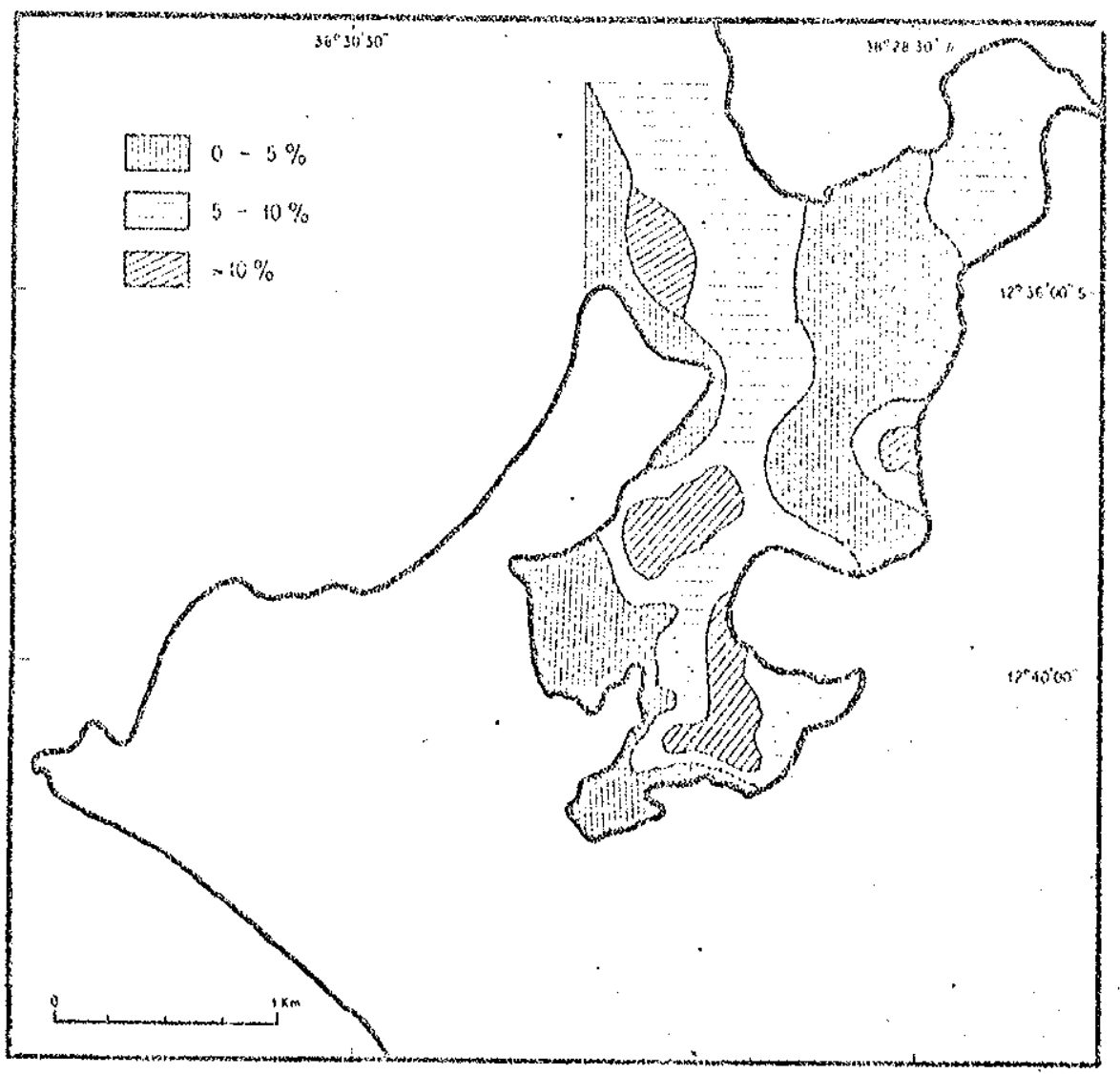

FTGURA 26 - Distribuição de matëria orgânica em Itapagipe (VILAS BOAS \& WASCIMIN JO, 1979) . 


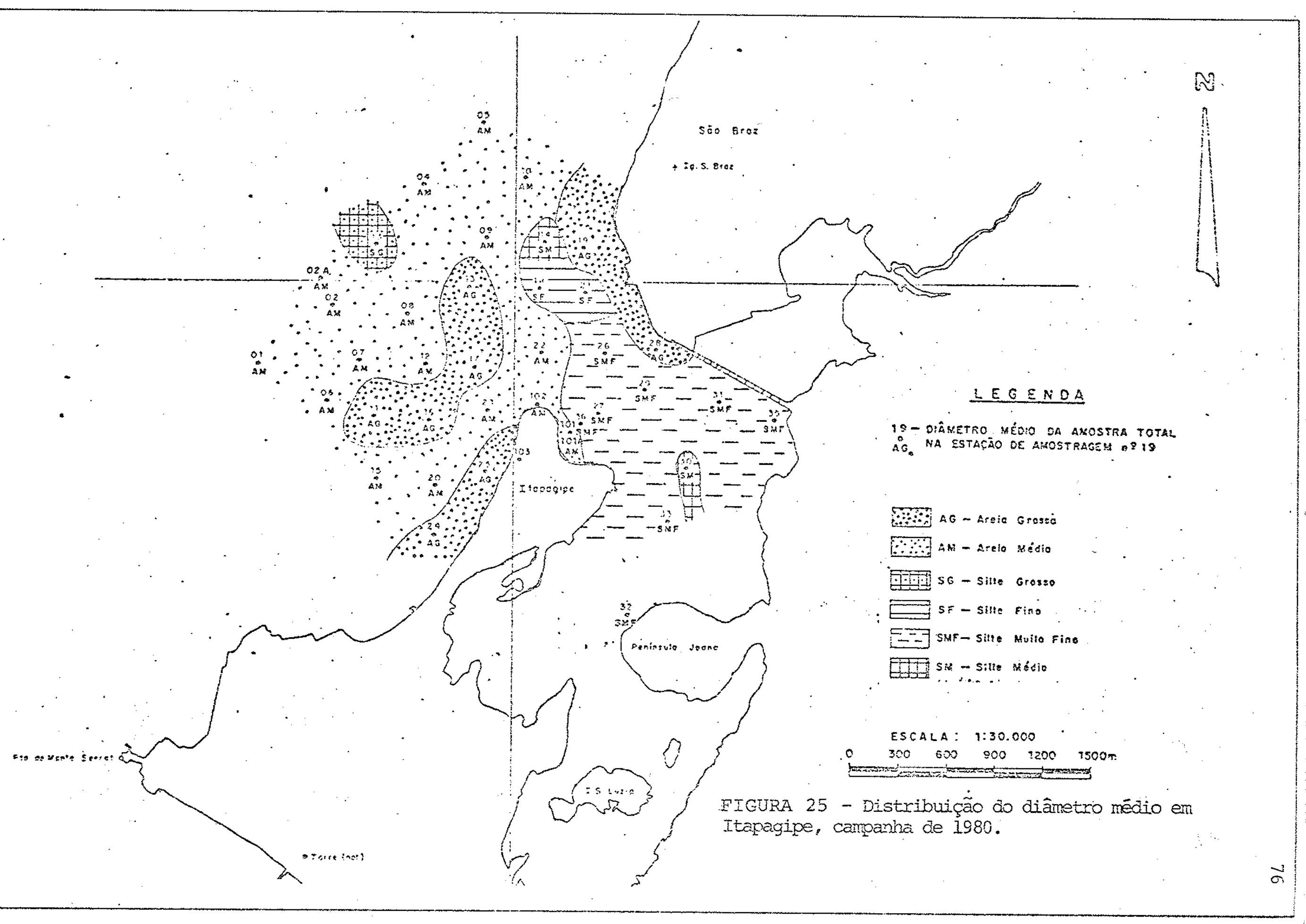


tes com os de VILAS BOAS \& NASCIMENTO (1979). A distribuição de teores de matëria orgânica obtida pox VILAS BOAS et ali e por nōs (FIGURA 27) apresentam algumas diferenças.

A distribuição do diâmetro médio não pode ser interpretada de modo simples, associando-se-lhe unicamente a energia de trans porte dos sittios correspondentes às diversas fäcies reliquiares, indica tivas portanto de dinâmica pretérita. Entretanto, hä que aânitir que as arejas se movem, dadas as informaçöes sobre o assunto.

Assim, o padrão textural seria parcialmente indicativo da dinâmica sedimentax atual, o que nos levaria a adnitix migraçãodo bunco arenoso que se coloca na face externa da ponta de Itapagipe para o interior da enseada, conforme sugere a distribuição das arejas grossas. Esta migração de arejas poderia ser atrjbuĩa a intervenção de corrente local, que redistribuiria ao longo da cos ta o material da zona de arrebentaçăo. Entretanto, a distribuiçăo de sil tes, no trecho entre enseada e baia, pode ser quase que delimita-. da pela curva de $5 \mathrm{~m}$, coincidindo pois con o paleocanal que aí exis te. Nesse sentido, esse trecho de paleocanal funciona como una cu ba de decantação.

A situaçăo descrita sugere então entrada, por arraste, de areias, maxgeando pequena extensão da entrada da enseada, e depo siçäo de finos transportados em suspensäo, nas partes interiores da enseada e paleocanal.

Os Einos podem tex dupla origem: continental e marinha; nes te ütimo caso, adentraxiam a enseada transportados por correntes de maré, e se depositariam, quando estas perdessem a velocidade, na regiäo do paleocanal, gue funcionaria como obstäculo e armadi... 1ha.

Nesse sentido, buscou-se dados adicionais na aistribujgăo de matëria orgänica, admitindo-se que esta pudesse ser indicativa da regiäo sob maior influencia de äguas contjuentais. Os resultados obtiơos, mostrados na FIGURA 27 sugexem como area de influência de aportes continentais a enseada, o paleocanal, e pe quena porção ao longo da costra a norte da enseada. Esta situação e sugestjiva de que as correntes de vazante, a cujo barramento se associa a deposiçâo dos finos, passem pelo paleocanal.

Assim, embora não seja possivel reconstituix todas as etapas de transporte e deposição de sedimentos, variāveis segundo a 


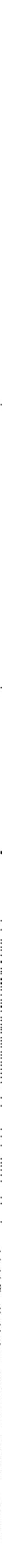


marê, apresentar-se na FIGURA 28 um esboço da provävel circulação dos sedimentos de superficie de fundo.

D. Caracteristicas da sedimentação atual na Baía de Aratu.

A formação e constituição dos sedimentos da Baĩa de Aratu fo ram estudadas por BITTENCOURT et a $i$ i (1974) e LEÃO \& BITTENCOURT (1977). Entre as principais conclusões apresentadas por BITTENCOURT et alii (1974), sintetizamos as seguintes:

a) A Baía de Axatu apresenta, em geral, um ambiente de fra ca energia, desenvolvendo-se na zona do canal umaenergia um pouco major. A energia que mais pode influir sobre a distribuição e a deposição dos materiais está ligada à ação dos marés, sob o efeito do fluxo e refluxo atravês do canal.

b) Alguns depósitos grosseiros são encontrados na baía, cons tituídos predominantemente por conchas e fragmentos es queletaj.s originados no local, não estando portanto rela cionados à ação de correntes e ondas.

c) Nas desembocaduras de alguns rios, como os rios de Maca co, Cotegipe e do Cörrego são João, existem depösitos re presentados por grãos de quartzo, devendo estar relacio nados a antigos depósitos fluviais do Quatemärio, já que esses cursos de àgua, atualmente, não têm competência pa ra trazer e acumular material arenoso grosso.

d) A presença de mangues com vegetação caracteristica, na desembocadura dos rios e nas bordas da baja, permite maior aprisionamento e acumulação de material fino siltoso, mis turado com material grosseiro.

A distribuição textural dos sedimentos de superficie de fun do, segundo esses autores, pode ser vista na FIGURA 29. Em 1980 rea. lizamos coleta de amostras no entorno da ärea de possivel instala ६̧ão de terminal maxinho, obtendo paxa todas a classificaçäo de silte muito fino. Alguma vaxiação. foi observada nos valores de curtose (FIGURA 30), para que sugerimos interpretação semelhante à feita no caso de sepetiba, ou seja, as distribuições leptocūrti cas indicariam atuação mais efetiva de correntes de fundo. 


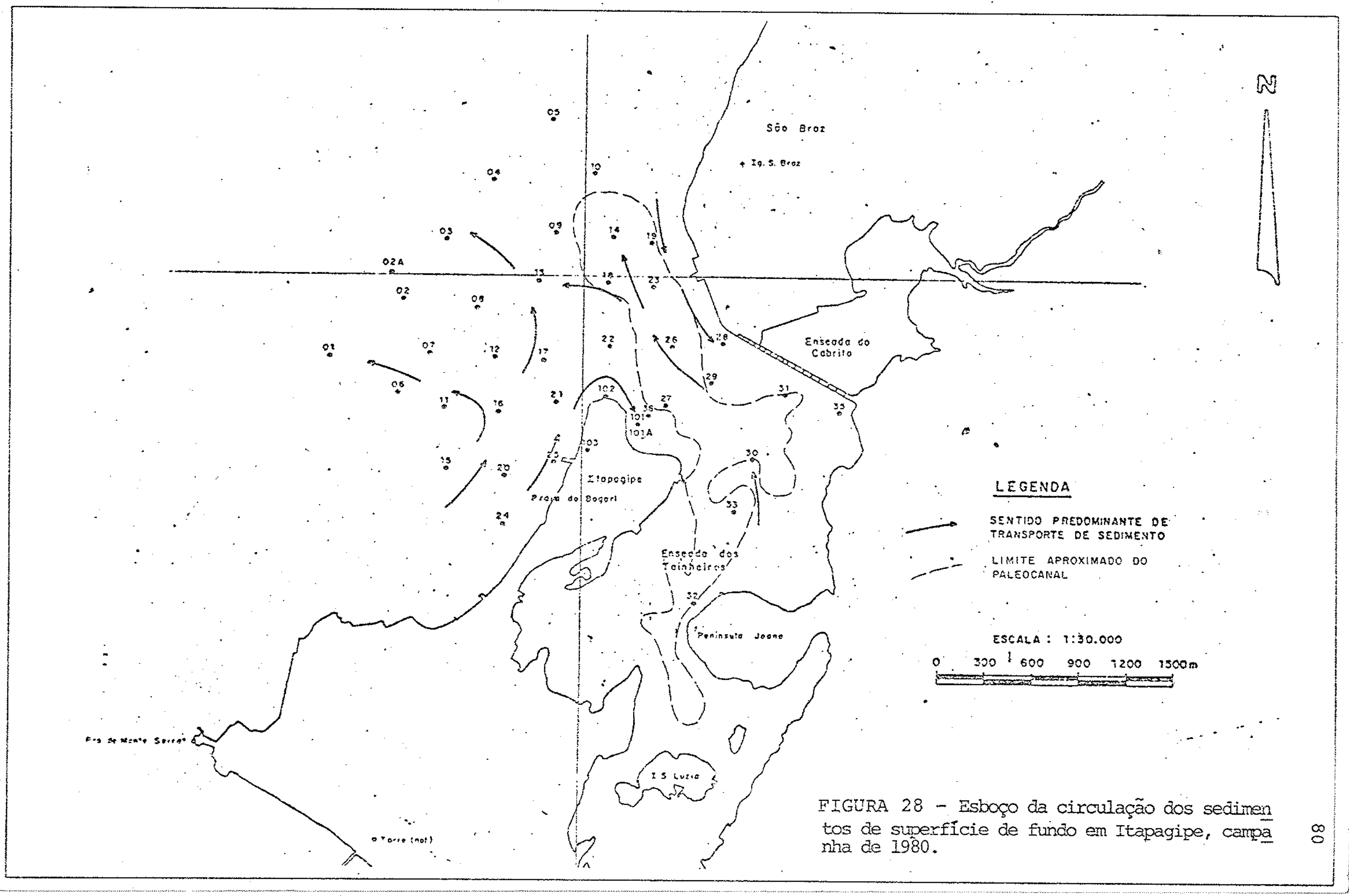




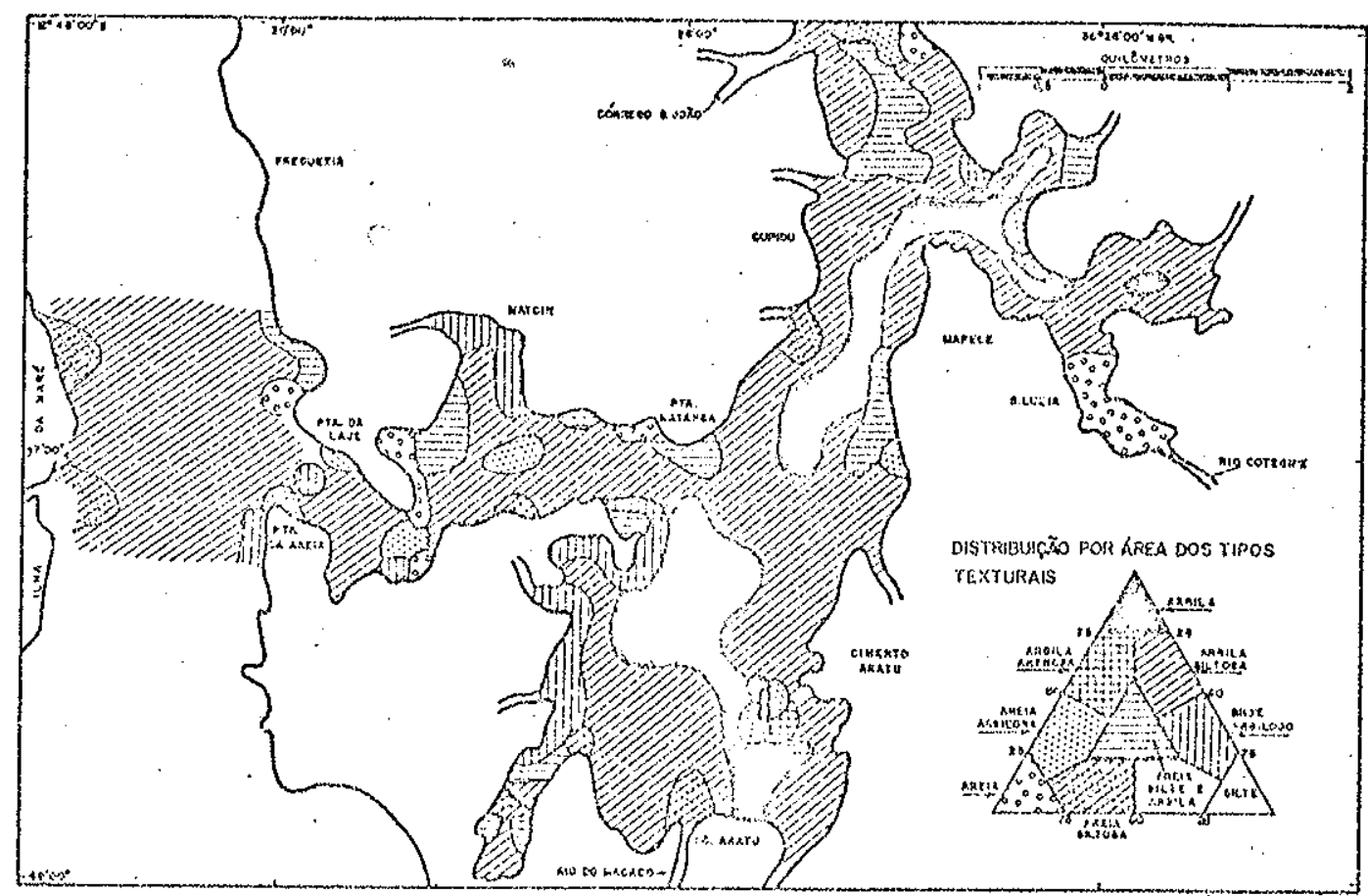

FTGURA 29 -. Distribuição de tipos texturais na Bẫa de Aratu (BITTENCOURT et alii, 1974.).

Ademais, a avaliação das condições de sedimentação na Bẵa de Aratu deveria fornecer, de imediato, indicações para a escolha de ăreas de lançamento de cerca de $100000 \mathrm{~m}^{2}$ de material aragado, resultante da escavação de canais de navegação. Levando em conta. critéxios econônjos, as äreas escolhidas deveriam estar situadas num rajo de $2 \mathrm{~km}$ do local da dragagem.

Considerou-se ainda, as seguintes restrições:

- não lançar o material aragado diretamente nos canais prin cipais (correspondentes aos paleocanais), pois podexiam cau sar alterações temporärias importantes no fundo e no regi. me de distribuição dos sedimentos, inclusive refluxo do ma terial lançado, ao local da obra.

- não lançar o material sobre mangues pröximos à obra, nem so bre mangues marginais aos canais principais de navegação.

Com base nessas premissas de remoção foram delimitadas äreas 


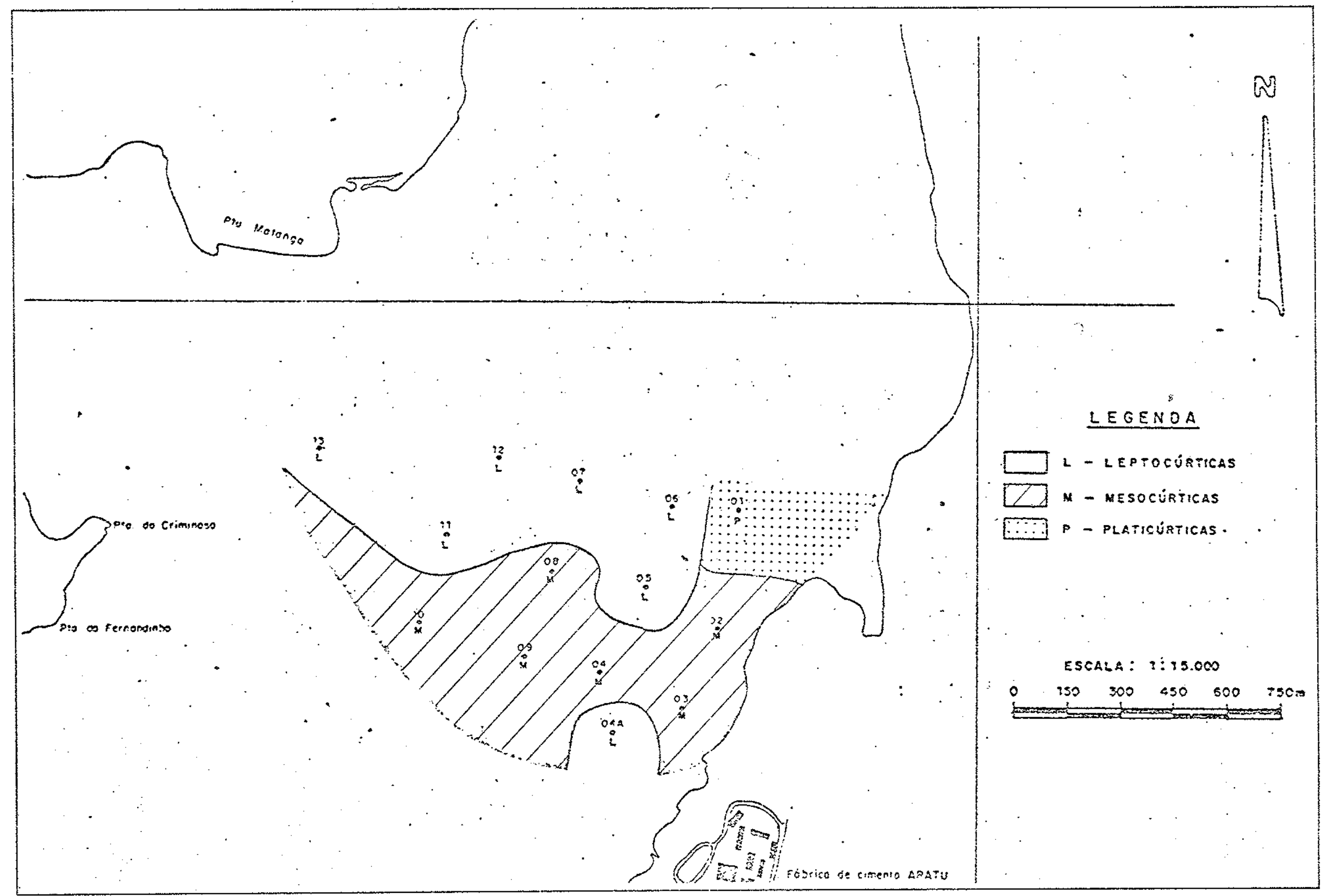

FIGURA 30 - Distribuição da curtose na Baĩa de Arąitu, camanha de 1980 
em que haveria menor possibilidade de remoção räpida do material dxa gado lançado (FIGÚtA 31 ).

Levando em conta o caräter de cjrculação restritia de sedimen tos na Baía de Aratu, pode-se considerar que as partes terminais $\mathbb{N}$ e S da baía sejam locais de menor energia do meio circulante.

Considerando a limitação de distância $(2 \mathrm{~km})$, fica exclúia a zona $\mathrm{N}$.

$\mathrm{Na}$ zona $S$, por outro lado, movimentações locais do material dragado lançado poderão afetar o Iate Clube.

outra alternativa, porém já no limite de distância de $2 \mathrm{~km}$, é a reentrância que existe entre a Porte do Fexnandinho e a coroa do Cação. O material que venha a ser ấ lançado poderá ser paxcialmen te removido para o canal pxincipal, nada fazendo porërn esperar que venha a refiluir para o local da obra.

outro local, finatmente, colocamse logo a $\mathrm{N}$ da coroa dos rex reiros, entre o mangue e a isobata de $3 \mathrm{~m}$. Neste caso tarbem, acré dita-se que remobilizaçōes do matenial dragado lançado venham a

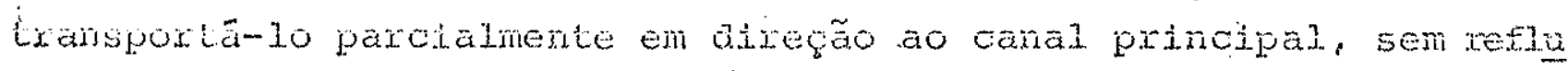
xo importante no local da obra.

sugexiu-se ainda que o matexial näo. fosse concentrado em un unico local, mas distribuido pejas alternatjvas propostas, especial. mente ac duas tutimas. 


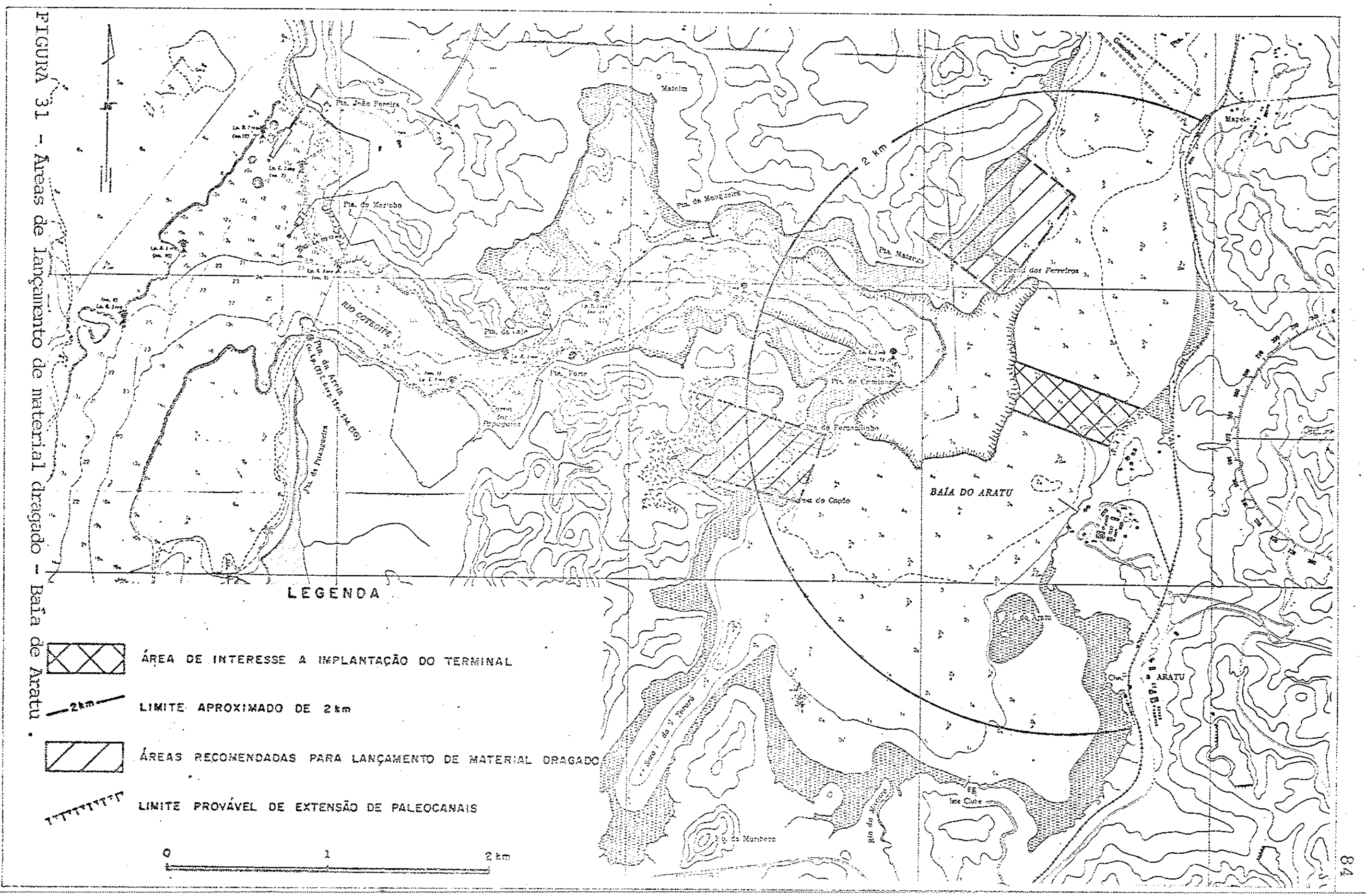




\section{CAPITULO V}

PORTOS EM ESTURRTOS: OS CASOS DO POTENGI, ESTADO DO RTO GRANDE DO NORTE; DE SANTOS, ESTADO DE SÃO PAULO; E DE ITAJAI-AÇU,ESTADO DE SAITA CATARINA.

\section{APRESENTAÇÄO}

No contexto morfológico da pouco recortada costa brasileira, mencionada pos PENTEADO (1970), nosso litoral "extenso, porëm pou co recortado, conheceu um räpido processo de seleção de pontos fa voxäveis, não demasiadamente difícies de distinguix, em virtude de serem pouco numerosos ... Entre os värios pontos que, pelas suas condicões, puderam atrair desde logo o europeu, inclui-se oconjun to insular do litoral vicentino" (PETRONE, 1965, p.13-1.4). Aí de senvolveu-se o porto de Santos, o mais importante do país,aprovej tando portanto um estuärio, e não um privilegiado recorte debaía. Nele tivemos ocasiäo de realizax värias investigações, entre 1973 e 1985, parcialmente publicadas (FÜLARO \& PONÇANO, 1976 ; FÚLA RO et azi i, 1976; PONCANO \& FÚLFARO, 1976).

por outro 1ado, em 1977 estudamos o estuärio do Potengi(FOL, FARO et alii, 1978), e em 1982 e 1983 o estuärio do Itajaí, de sorte que temos resultados referentes a estuärios de três regiöes fisiograficamonte distintas.

Assim, o mais mexidional dos três situa-se em região de clima subtropical, de circulaçäo atmosfërjca francamente governada por frentes polares, cuja influência jä é atenuada à altura de santos, a cujo setentrião comę̧a a se fazer sentir a influencia do antici. clone mesoatlantico, dominante en toda a costa nordeste a partir de Salvador, atravês dos aliseos. As correntes maritimas que inte ressam a costa brasileixa são apresentadas na FIGURA 32.

\section{ESTUARIO DO POTENGI}

o porto de Natal, situado no estuärio do Potengi, assim co mo o de Fortaleza, "tornaram-se importantes na navegação de cabotagem o de longo curso, quando se intensificarem as exportações de sal. e algodão, no final do século xIx e início do século xx.Ainda em 1970, o sal figurava como produto importante na exportaçäo pox cabotagem em ambos os portos. Contudo, Fortaleza mantëm a prima- 


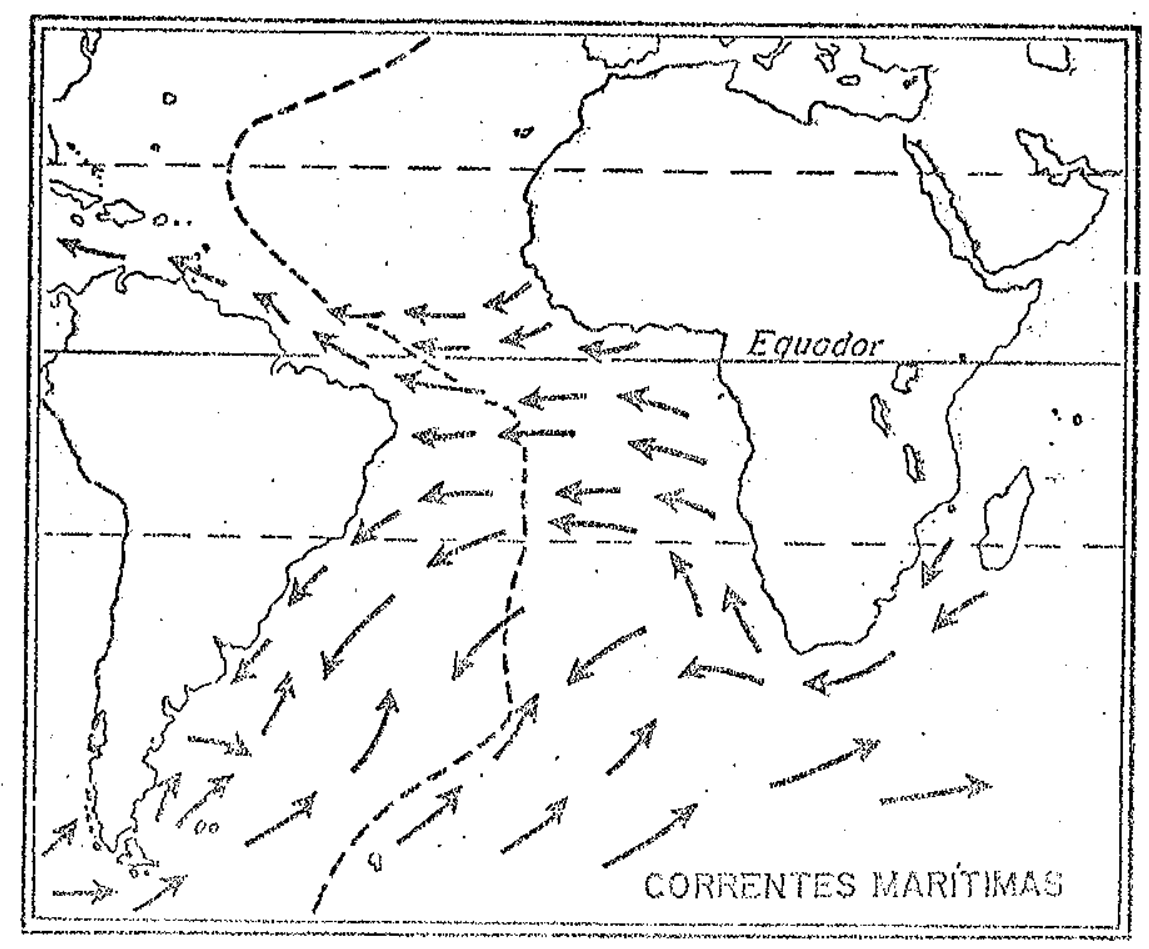

FIGURA 32 - Correntes maxitimas do AtIärtico sul (ANDRADr, 1970, P.409)

zia regional..." (Mesourma, 1977, p.221). Mais recentemente vem o Porto de Natal sexvindo de apoio a prospeçäo petrolifera da Bam cia potiguars.

As investigacóes que procedenos no estuáno do rotengi visa ram caxactexizax. Ihe a constitugão dos seamentos de superitoie de fundo, dela infexindo constderaçöes de ordern dinandca, cono sub sifar a projetos de melhoria das condigoes ae acesso ao porto. os resultados obtidos integram cadastro de caracteristicas do meio fisico da area en foco. Os trabalhos desenvolvjdos seguixam a orjentação geral exposta no cApIruto 2.

A. Geologia

Na regiäo circunvizinha a Natal podem ser reconhecidos basi camente dois grandes conjuntos litológicos: rochas do Grupo Barm reiras e sedimentos inconsoljdados quatemarios (FTGURA 33 ).

1. Grupo Barreiras

As rochas do Grupo Barrejras presentes na ärea podem ser en 


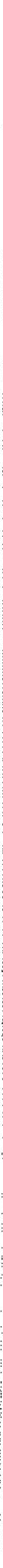


guadradas em duas subunidades distintas, quanto a litologia e lo cal de ocorrência.

A primeira subunidade é constituía por arenitos por vezes; conglomeráticos com grãos e grânulos de quartzo angulosos, forte mente cimentados por óxidos de ferro, tornando o conjunto bastante duro e resistente. Algumas variações na intensi dade de limonitização dão origem, localmente, a arenitos mais friä veis.

Os afloramentos de arenitos Ismonitizados ocorrem principal mente na faixa costeira ou bastante próximo dela, e em cotas mais elevadas são observados sedimentos areno-argilosos e argilomareno sos incipientemente estratificados, de coloraçäo variegada tịpi ca, com frequentes tons avemelhados, somando falesias, algumaz das quals atuamente retinadas da linh de quebra mar. Exemplo no tâvejs dossas falesias säo encontrados em pirangi, na praja de Areia preta (Ponta do Morcego), na praia do Mejo, e na Parrejra do Inferno, a sul de Natal.

hs camadas variegadas expostas mos falestas mais altas pare cem sex correlacionaveis a Fomagäo Guararapes definda pox Masp SOONE et ali. (1972).

A segunda subuniade de rochas do crupo Barreiras pxesente na area constitura por arentios argilosos escranquigados, mal selecionados, com matexial caulinico e exeqüentes intercalagôs de niveis conglonexaticos com seixos de quartzo ben axredondados. $\mathrm{Es}$ tes axenitos que ocorxem mas paxa o interior, em notävejs exposi çoes nos cortes da rodovia que Ijga Natal a Macaiba, poden ser cor relacionados à Formação Macaiba proposta por MABlisoone et ali (1972).

As rochas ao Gxupo Barreiras, apresentam topo aplainado,bas tante recortado em planta, onde assentammse em discordancia os se dimentos quatemarios.

2. Sedimentos Quaternärios

Os sedimentos mais modernos encontrados ra área de estudo re presentam ambientes de mangues, dunas, prajas e aluviōes fluviais. săo no gexal inconsolidados e predominantemente arenosos, restrin. gindo-se o matexial siltomargloso aos mangues.

No $\mathrm{km} 4$ da rodovia Natal-Macaj̉ba, um corte em areias eölicas 
apresenta em sua base depösitos de mangue constituídos por argilas cinza escuras. Este antigo mangue tem seu topo cerca de 7 a $8 \mathrm{~m}$ a cima do mangue atual, atestando um nivel de mar regional mais ele vado em época prê-atual.

\section{Recifes}

Recifes de arenito dispostos de modo aproximadamente parale Lo à atual linha de coșta são encontrados ao longo das prajas de Jenj.pabu e do Mejo, a norte e a sul de Natal, repectivamente.

Estes depösitos possuem forma alongada segundo a praia atual. e são formados por arejas grossas conglomeräticas e corglomerados de matriz axenosa, fortemente cimentados por material carbonätico. Os seizos são de quartzo e têm superficie muito arredondada.

Nos recifes são observadas estruturas de escavaçäo e preen chimento, e estratificaçoses cruzadas com direçoses de transporte bastante heterogeneas. Pröximo ao Forte dos Reis Magos o padräo de estratjifições cruzaảas é semeinante ao que se observa na deposi Găo atual das arejas na barra onde varias direçoos diferentes de transporte se sobrepöem. Afastandomsc do forte em djuegão sul, o padrão dos estratos cruzados toma-se mais regular com direços de pajeocorrentes parajelas ou Iigejramente obljguas à atual linhade costa. O prolonganento deste recife na praia do Mejo, entre o For. te dos Reis Magos e a ponta do Morcego, parece apresentar duas uni. dades litológicas aistintas, una mais fina na base e outra majs grossa, passando a conglomeratica, para o topo.

Ajna na praía do Meio foj vexificada a existência de um re cife mais interno constituja por axeias bem selecionadas de cor creme, cimentadas pox caxhonatos, com estratifiçą̃a planowparale la, e alguns nivejs mais escuros representando deposiçăo de mine rais pesados. Esse recife interior estä sotoposto ao recife do ror te.

As estruturas sedimentares e as caracteristicas texturais ob servadas em ambos os recifes levam a supor que o recife mais inter no represente uma antiga praia, enquanto que o recife de Natal cor responda a uma barrejra arenosa construjda nas proximidades a pä leo-barra do potengi.

os recifes da praia do Meio têm seu topo muito aplainado por 
erosão marinha. Atualmente continuam sendo atacados pelas ondas, porēm de maneira divexsa. O texraceamento se deu com um nĩvel de mar mais alto, urna vez que o embate das ondas atuajis se dä apenas en seu flanco voltado paxa leste; a erosão resultante levou à abextura de canais que na maxë alta permitem a entrada do max na parte interior do recife.

o recife da praia de Jenjpabu não pôde sex observadoem deta the, pois encontra-se mais afastado da linha de praia, porem, uma amostra nele coletada mostrou que se trata de un recife de arenito grosso cimentado por carbonatos que deve estar relacionado ao mes mo evento que deu origem ao recife externo da praia do Meio.

Em pixangi do sui, durante a maxe baixa e ao largo, observa-se uma Iinha de quebra max demarcando tambëm um recife.

Os recifes de Jenipabu, de Natal e de Pjxangi do sul encon tramse associados às foz dos rios cearä mixim, potengi e piun res pectivamente. Suas caracteristicas de barras arenosas sugeren cex ta permanência dessa rede de duenagem ao longo da histórja geolögica mais recente, guaternäria. Sua preservação estä ligada em primeira instância à cimentaçäo por material carbonätico, que pos sibilita a litificação destes depöstos, e sua forma atual estä condicjonada à erosão e terraceamento marinho postexiores, em ni. veis de mar ligeiramente diversos do atual.

\section{Mangues atuais}

Os mangues atuais concentram-se nas bordas dos canais de ma rê do potengj.jundia. tendo uma expressăo em ärea um tanto reduzi. da. partindo-se da borda do canal principal ou dos canais secunä rios para o interior, verificamse a diminuição progressiva dos man gues, que vão aando luģar a vegetaçäo xasteira tipica de planicies arenosas. Mesmo nas äreas de ocorrência dominante de mangues enoon tram-se "ilhas" de material axenoso.

As numerosas "jlhas" arenosas que se encontram entre os man gues do potengi/Jundiai podem correspondex a antigas planicies ma rinhas pouco elevadas. Possuem altitudes pouco superiores às ma rés altas e são frequentemente utilizadas para a instalą̧̃o de sạ jinas, pois a ausencia de material sitito-argiloso em sua constitui ção favorece a näo contaminação do sal extraído.

para o interior, em aireção ao alto estuáxio, observa-se a 
vegetação tipica de mangue bordejando o rio Jundiai até Macafiba, atestando dessa forma a influência das marés até essa localidade. Os sedimentos depositados nos mangues são predominantemente sil.to-argilosos, embora material arenoso fino e micäceo ocorra com fxequência em muitos pontos observados.

5. Praias e dunas

As praias atuais são embutidas entre pontões rochosos froma dos pelos arenitos Iimonitizados do Grupo Barreiras, sendo constI tuỉas por areias médjas e grossas inconsolidadas. Para o interior dão lugar a extensos campos de duras.

A grande mobilidade do material arenoso aliada ao regime de ventos explicam a ampla distribujgăo em áxea de depōsitos de dunas que se estendem por toda a faixa costeira, avançando tambëm para - intexior alguns quilometros. Na fajwa costeira as dunas säo mui to bem desenvolvidas, atingindo cotas superiores a 100 metios.

A sul de Natal, a paxtix da ponta de Mãe muiza, desenvolvese um possante campo de dunas orientadas segundo NW SE que se in texrompe ra localidade de ponta Negra, reiniciando-se em segujda a sul do acidente geografico denominado ponta Negra. Este campode dunas altas, formadas por arejas de cor branca, possuj uma cober tura vegetal uniforme, mostrando estabiljzaça en período prë atual. Seu contato oeste é abxupto e muito bem marcado, contrastan do com a superficie aplainada nos sedimentos texciärios, que nesm. te local formam seu substrato. o contato leste e exosivo, evioencian do um avango do mas sobre as aunas, recortandomas e estabelecendo a praia atual.

Neste local as dunas assentam-se sobre depositos inconsoli dados de areias grosseiras, mal selecionadas e mal arredondadas com abundantes estratificações cruzadas formando uma falesia baixa com cerca de $3 \mathrm{~m}$ de altuca. Próximo à ponta Mãe Luiza estas areias dão luagar aos arenitos Iimonitizados do Grupo Barreiras, que a partir deste ponto formam o substrato das dunas. Na ponta Negra o substrato das dunas altas tambëm é formado pelos arenjtos limoni tizados.

No campo de dunas, a sul de Natal, as exposições de areias sujeitas à ação do vento atual são pequenas e restritas, jä que a cobertura vegetal fornece uma proteção eficiente. 
Ao conträrio, a norte do estuärio do potengi/Jundjai, aa Re dinha a Jenipabu, a cobertura vegetal é rarefeita, com ärvores de raizes expostas e coqueixos de ate $20 \mathrm{~m}$ de altura soterrados até a copa, atestando uma retomada dos processos eólicos, que leva ao desenvolvimento de zonas de erosão instaladas sobre as dunas mais antigas. Formam-se, neste campo de dunas, corredores de vento onde são encontrados sedimentos de granulação mais grossa e maxcas onduladas de grande comprimento de onda.

Tanto a norte como a sul do potengi, as dunas para o inte riox são menores, passando a coloração de suas areias debranca pa ra amarelada e avermelhada. Decrescem tambén em altura e mostram formas longitudinais nitjdas orientadas tambëm segundo NW-SE.

o avanço das dunas para o interior condjciona a presenga de algumas arenagens, como no caso do riacho ponte velha a nordeste de Paxnamirim, que neste local tem seu curso adaptado ä direcro das dunas. Ao mesmo tempo este avango deve tex barrado alguns xios an

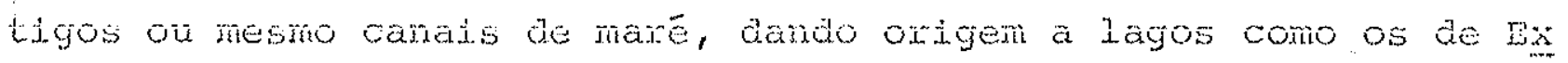
tremoz e Guamoré pröximos à ponta de Santa Rita e o de Juiqui prö ximo à ponta do cotove 10.

Conforme vimos, as dunas a sul do potengi achammse relativa mente estabijizadas, de sorte que, aada a aparente predonjânoja dos ventos sudeste na região de Natal, as areias eölicas näo devem contribujx significativamente para o assoreamento do estuärio.

\section{B. Geomorfologia}

1. Compartimentą̧ão geomorfolögica da área

o relevo na regiäo de Natal pode sex dividido esquematicamen te em três compartimentos; delimitados em altitude aproximadanente pelas cotas de $10 \mathrm{~m}$, de $40 \mathrm{~m}$, e de $80 \mathrm{~m} 90 \mathrm{~m}$, respectivamente.

o nivel de $10 \mathrm{~m}$ englobaria as planícies arenosas baixas e os mangues situados ao longo do vale do Jundiaj/Potengi. o nivel de $40 \mathrm{~m}$ è separado do anterior por falésias, muitas das quais jä interiorizadas.

para o interior, o nivel de $40 \mathrm{~m}$ é representado por ima su perficie aplainada nos arenitos argilosos esbranquiçados, ou por sedimentos arenosos intemperizados, de forte coloração verme lha.

Finalmente o nivel de $80-90 \mathrm{~m}$ ë representado por dunas de 
areias brancas jä fixadas pela vegetąão, que recobrem de maneira descontinua o nivel de $40 \mathrm{~m}$. Essas dunas concentram-se principalmente na faixa costeira e vão dimjuujndo em expressão para o inte rior.

\section{Fejçöes morfolögicas}

Dentro dos compartimentos acima esquematizados podert ser dis tinguidas como principais as seguintes feições: tabuleiros,baixas planícies, dunas e praias.

Os tabulejros mostram em seu topo uma superficie mujto pla na aproximadamente na cota de $40 \mathrm{~m}$ que em sua maior parte é sustentada por sedimentos terciärios do Grupo Barreiras. Rios e pe quenos riachos cortam os tabuleiros, estabelecendo aluviões de pe quena expressão. Rios de major porte como o potengj/Jundiai, em suas porçoses inferiores, entalham majs intensamente os tabulejros terciärios estabelecendo amplos aluviões.

Sobre os tabuleiros texciarios encontrammse extensos campos de dunas, alçados algumas vezes de atè $100 \mathrm{~m}$ sobre o nivel do mar. As aunas presentes nestes campos, embora apresentando às vezes for mas mais complexas, são no geral do tjpo longjtudinat, podendo sex. observados algums cordões de ate 6 kru de comprimento.

o maior desenvolvimento das dunas se dá ma faixa costeira, decrescendo os campos de dunas, em altuxa e em extensäo, para o juteriox."

As planif ies baixas, que incluem os mangues atuais, separam-se dos tabujeiros através de falesias, muitas das quais jã inativas, uma vez gue se encontram afastadas da atual inha de quebra mar.

As talessias, feiçöes tipjcas de erosão marinha, estão escuI pidas em sedimentos texciärios do Grupo Barreiras, formando pare dões verticais de ate mais de $40 \mathrm{~m}$ de altura, como ocorre na Bar-m reixa do Truerno.

As falesias inativas no geral separam-se da linha de quebra mar pela praia atual e por uma planicie arenosa baixa de constxu ção marinha, como pode ser obsexvado na praia do Meio.

As pxaias da costa próxima a Natal são bastante caxacterís ticas, desenvolvendo-se entre pontas de arenitos fortemente cimen 
tadas da Formą̧ão Barreiras, com concavidade para sul. Estas fei Cõos, aliadas à pröpria forma da barra do potengi seriam indicati. vas de transporte litorâneo por corrente costejra no rumo norte (SILVESTER, 1968, 1974):

\section{Evolução geomorfológica}

Segundo FUtFARo et a.ti (1978, p.86 e 87), durante o último periodo glacial, "estando o nível do mar vārias dezenas de metros abaixo do atual, deu-se o entalhe e alargamento dos vales fluviais instalados sobre os tabuleiros terciários. os depósitos marinhos costeiros achavam-se então recuados mais para o interior da plata forma continental, e o vale do Potengi/Jundiaí encontrava-se em formặão".

"Seguiu-se uma fase de subida de nivel. marinho, que chegou a atingir uma cota cerca de $7 \mathrm{~m}$ acima do atual nivel do mar, como é testemunhado pelo depósito de mangue suspenso do $\mathrm{km} 4$ da rodovia Natal-Macaỉba. Durante a fase final desta transgressão processou- entahe das falésias atualmente interiorizadas, bem como a deposição de lençöis arenosos em diueção ao continente."

"Teve jnício então o recuo do mar em busca de seu njuvel atual, com o consequente estreitamento do espelho d'ägua na região cos respondente ao vale do potengi/Juzdiat. Jsto propiciou a formação de manquesais a partir de fundos em processo de emersão, que em alguns locais isolaram pequenas pianícies arenosas formadas pelos depósitos maxinhos da fase anterior. Concomitantenente deve ter ti do início a formạ̃a dos campos de äunas, provavelmente por ação eolica sobre mateniais fornecidos pelo enxugamento de extensas su perficies costeiras anteriomente submersas."

"Em nIvel do mar jä pröximo do atual, por combinaçäo da atuą̧ão de correntes costeixas e diferenças de resistência litojö gica das rochas do Grupo Barrejras, formaram-se as praias escava das entre pontões rochosos l.imonitizados, caracteristicas das pro. ximidades de Natal. Ao mesno tempo houve coluvionamento em dire ção ao interior do continente, testemunhado por sedimentos axenom argilosos de cor creme, que preenchen tubos antexiormente formados por erosão marinha nas falésias da ponta Negra e ponta do Moroego."

"Na fase final de descida do nivel marinho teve lugar a for mação, e subsequentes terraceamento e emersão, de barreiras areno 
sas associadas às barras do Potengi/Jundiaj, Cearä-Mirim e Pium, originando os atuais recifes."

"Estabeleceu-se então o mar em seu nível atual, permitindo que a ação das ondas das marés enchentes abrissem passagens nos recifes mais próximos à costa, como na região da praia do Meio, com a formação periōdica de pequenos corpos d'āgua circunscritos pelo continente e recifies."

"Correntes paralelas à costa retificaram a linha costeira, formando falësias nas porções mais proeminentes e homogêneas das rochas do Barreiras, tais como a Barreira do Inferno."

"A atuação eóljuca deve tex sido efetiva em todo o pexíodo re gressivo, havendo porëm progressiva fixação dos campos de dunas a. sul do estuario, enquanto que a norte ela persiste ou sofre uma a centuada retomada."

"Com a estabilização do nÍvel marinho o estuáxio do Potengi/ Jundiat adquiriu contorno proximos aos atuajs, modificados täo so mente pelo continuo crescimento de manguesais canais de mare aden tro, e por remobjilzações de sedimentos, ora escavando seu leito e margens, oxa deslocando bancos arenosos."

c. Variações batimëtricas

1. Morfologia atual

A atual batimetria da áxea de estudo, observada através das cartas DNH nos 802 e 810, pode ser dividida em dois grandes compartimentos com caracteristicas distintas, a saber, compartimento de mar aberto, e compartimento do estuärio, com canais de maré.

No compartimento de mar aberto, em relação aos traços mais amplos, observamse à cerca de $15 \mathrm{~km}$ a nordeste de Natal, que o con tonno da isöbata de $20 \mathrm{~m}$ descreve uma reentrância de direçäo NESW, demarcando com clareza um pequeno canal. No cextro deste pe queno canal encontram-se profundjdades de 21 a 22 m, margeadas por fundos de 15 a $18 \mathrm{~m}$.

Pouco mais a sul, o contorno da isóbata de $20 \mathrm{~m}$ delineia uma crista estreita e alongada, con direção N-S, que constitui neste local um alto com profundidades de 15 a $18 \mathrm{~m}$. Nas max gens dessa crista as profundidades crescem rapidamente, encontran do-se em seu lado oeste profundidades em tomode $23 \mathrm{~m}$. No lado leste a 
passagem é mais abrupta, encontrando-se fundos de 25 a $28 \mathrm{~m}$ depro fundidade.

Este conjunto de feições se assemelha muito à atual barra do potengi, podendo corresponder a uma páleo-barra e um päleo-recj.fe construídos em um nível de mar de cerca de $20 \mathrm{~m}$ abaixo do atual, segundo o esquema de oscilações marinhas anteriormente suge rido.

Ainda na ārea de mar aberto, com respeito ao setor mais pró ximo da costa pode-se observar uma nitida mudança no contorno das isobbatas de 5 a $1.0 \mathrm{~m}$, a partir da barra do potengi para norte e parát suj.

A sul da barra, a isobbata de $1.0 \mathrm{~m}$ margeia a costa a uma dis tância média de cerca de $800 \mathrm{~m}$, aproximando-se progressivamente da costa em direção ao norte. Junto a Forte dos Reis Magos encontra - se a apenas $200 \mathrm{~m}$ do recife. padrão idêntico é apresentado pela isobbata de $5 \mathrm{~m}$, que chega mesmo a encostar no recife a sul do For te dos Reis Magos.

A norte da barra do Potengi as curvas afastam-se da costa situando-se a isobbata de $10 \mathrm{~m}$ cerca de 2,0 a $2,5 \mathrm{~km}$ da praia da Redinha.

Este padrão de distxibuição das isöbatas evidencia que a norte do potengi ocorre una supexficie bem pouco inclinada forman do quase um "platô" com profundjdades em torno de 5 a 6 m, avançan do em direçäo ao mar aberto. por outro lado, a sul da barra a zom na de mudança de profundidades e bastante estreita confjourando uma superticie bastante inclinada, chegardo a constituir-se pröximo ao Forte dos Reis Magos em un paredão, onde encostado ao recife já se encontram profundiades de 7 e $8 \mathrm{~m}$.

A partix da isóbata de $1.0 \mathrm{~m}$ para leste encontra-se em toda a ärea, tanto a norte como a sul do potengi, uma superficie com pou cas ixregularidades, caindo suavemente para o mar com profundidades em torno de $12 \mathrm{~m}$.

Apenas a leste da ponta de Mãe Lujza ocorrem alqumas irregu laridades constituidas por altos fundos à cerca de $9 \mathrm{~m}$ de profundidade.

No compartimento do estuärio e canais de maré podem ser dis tinguidas zonas de maior profundidade situadas em geral defronte a zonas de baixa profundidade com bancos e coroas. 
"Observa-se que as zonas mais profundas do canal principal situam-se junto às margens côncavas, enquanto que as zonas de bai xas profundidades situam-se nas margens: convexas. Este padrão eví dencia um canal principal de seção assimétrica. Pouco a sul da pe dra do Oitizeiro encontra-se a ünica exceção, onde a grosso modo a zona mais profunda situa-se no centro do canal. Dentro das zonas de maior profundidade, em toda a margem direita do potengi, da pedra do Oitizeiro atë as proximidades da gamboa Manimbu encontra-se uma faixa alongada e estreita com profundidades em torno de $11 \mathrm{~m}$, sendo a zona mais profunda do estuärio. Também junto ã Redinha e na boca da barra encontramme grandes profundidades, chegando a valores de 13 e $15 \mathrm{~m} "$ (FULFARO et ali $, 1978, \mathrm{p} .87$ ).

Nos canais de maré, a norte da ponte rodoferroviäria de Tga pó, e na gamboa Jaguaribe, embora as cartas 802 e 810 näo contives sem informações batimétricas, foi possivel observar durante os trabalhos de campo, que persistia o padrão assimétrico do canal. principal, com maiores profundidades nas margens côncavas e baixios mas margens convexas.

"Para o intexior do estuário, as zonas de baixa profundi-dade situadas nas margens convex̣as estão no geral associadas ao crescimento dos mangues. Já no baixo estuärio, das proxinidades do farolete potengi até a barra, os bancos e coroas das zonas de bai xa profundidade são constituỉdos essencialmente por material are noso, como por exemplo nos bancos Jaguaribe e das velhas, acarrem tando uma grande mobilidade destas feiçöes. Observando-se as prom fundidades existentes nas proximidades da barra, ë notävel a pre. sença de uma elevação topogräfica justamente à entrada da barta, configurando uma solejra." (FULFARO et alii, 1978, p.87).

"Fntre os recifes de Natal e da Baixinha encontram-se pro fundidades de 12 a $15 \mathrm{~m}$; seguindo-se em direção ao interior do es tuário as profundidades passam para 8,7 e $6 \mathrm{~m}$, voltando a atingir. valores mais elevados 9, 11 e 13 pouco a sul da Redinha." (FULAARO et alii, j.978, p.87).

Ainda de acordo com FULFARO et alii (1978), as acima mencio nadas caractexísticas morfolögicas permitiriam atribuix a foz do potengi à categoria de estuário com soleira rasa, segundo a classificação de CURRAY (J969). 


\section{Comparação de cartas batimétricas}

Realizamos uma avaliação das variações batimêtxicas da re gião de interesse ao porto atravës de dois pares de cartas, defasados de 9 e 32 anos, respectivamente.

- primeiro conjunto utilizado compreende a planta do porto de Natal na escala I:2 500, levantamento realizado pela Fiscaliza ção do porto de Natal da Inspetoria Federal de portos, Rios e Canais em 1927, e a planta também na escala 1:2 500, levantamento rea lizado pela Fiscalização do porto de Natal - DNPN em 1936.

O segundo conjunto compreende as cartas no 802 , porto de $\mathrm{Na}$ tal, levantamento realizados pela Marinha do Brasil, Dixetoria de Hidrografia e Navegação, em 1941. na escala de 1:6 500 e 1973 na escala de 1:8 500 .

A escolha dos conjuntos a serem comparados baseou-se na uni formiaade de tëcnicas usadas na confeç̧äo das cartas. As cartas an tigas de 1927 e 1936 foram elaboradas de forma semelhante, já as cartas mais modernas da DHN foram elaboradas com têcnicas mais a vançadas, com a utilização de sondagens sônicas de perfilagem con tinua. Dessa forma julgou-se conveniente a comparação apenas entre as cartas que não apresentassem diferenças significativas quan to às tëcnicas de elaboração.

A comparação das cartas de 1927 e 1936 mostroumse de peque na confiabilidade uma vez que os contornos do canal principal do Potengi apresentavam grandes difexenças de uma carta para outra, invalidando parcialmente as observações sobre as variaçöes batimë tricas ocorridas nesse periodo.

Em virtude dessas variações foi dada ênfase à comparação das cartas da DHN que, embora apresentando algumas imprecisões, mos traxam-se mais uniformes quanto ao contorno do canal e posiciona mento planimétrico dos acidentes geogräficos (recifes, pontões, etc.).

O primeiro passo para o início da comparação foi a redução da escala da carta de 1941 de 1:6 500 para a escala de 1:8 500 cor respondente à carta de 1973. A seguix foram interpoladas geometri. camente as curvas batimétricas de $6,7,8,9$ e $12 \mathrm{~m}$ em ambas as cartas, mantendo-se as curvas de $1,3,5$ e $10 \mathrm{~m}$ que já estavam tra çadas tambêrn nas duás cartas.

o passo seguinte foi a superposição por transparência das 
duas cartas, avaliando-se então as āreas onde ocorreram mudanças batimétricas (TIGURA 34).

De acordo com FULFARO et alii (1978, p. 88), no setor demar aberto "a variação mais importante observada foi a sensível apro ximação em direção à costa da isóbata de $10 \mathrm{~m}$ nas proximidades da baxra. Na carta de 1941, a isóbata de $10 \mathrm{~m}$ situava-se à cerca de $1050 \mathrm{~m}$ do recife de Natal. Já em 1973 essa distância era de $220 \mathrm{~m}$, ou até menos, o que resulta numa variação de cerca de $830 \mathrm{~m}$ no pe riodo considerado".

"Na área do canal de acesso, situada a norte de gamboa Manim bu até a barra, tambēm predominam äreas de exosão, contudo nesta ärea ocorrem com mais frequência ăxeas de deposição, e a prōpria distribuição en planta das äreas de erosão/deposição ê mais comple xa."

"Com o objetivo de çetalhari as variações ocorxidas nesta üI tima axrea foram confeccionados 7 perfis transversais ao canal prin cipal, igualmente espaçados de $255 \mathrm{~m}$ e paralelos entre si. $\mathrm{A}$ fim de se obter melhor precisão foi convencionada uma linha de origem comum aos perfis. Esta linha é orjentada segundo N45E passando por cruzamentos de coordenadas. A escala horizontal dos perfis è a mesma da carta DHN no 802 (edição de 1973) e a escala vertical ë de 1:500, resultando numa sobrelevação de 17 vezes." (FIGURA 35 ). os resultados obtidos mostram predominância de exosão na margem direita do estuärio, e de deposição na esquerda.

D. Caracteristicas áa coluna sedimentar rasa da foz do poten gi.

De modo análogo as variaģöes batimétricas, pode-se compreen der a anälise da coluna sedimentar do fundo estuarino, pois ela também é orientativa na avaliação da história mais recente, que vem a permitir compreender a dinâmica atual.

Dezessete amostras foram coletadas por amostrador piston-corer, quinze das quais no interior do estuário (FIGURAs 36 a 38).

De acordo com Folfaro et alii (1978, p. 96 e 97) os resulta dos obtidos "permitiram cauacterizax quatro zonas distintas, que refletem diferentes condições de sedimentação paxa a região estua rina".

"A primeira zona compreende a porção tarminal do estuário, 


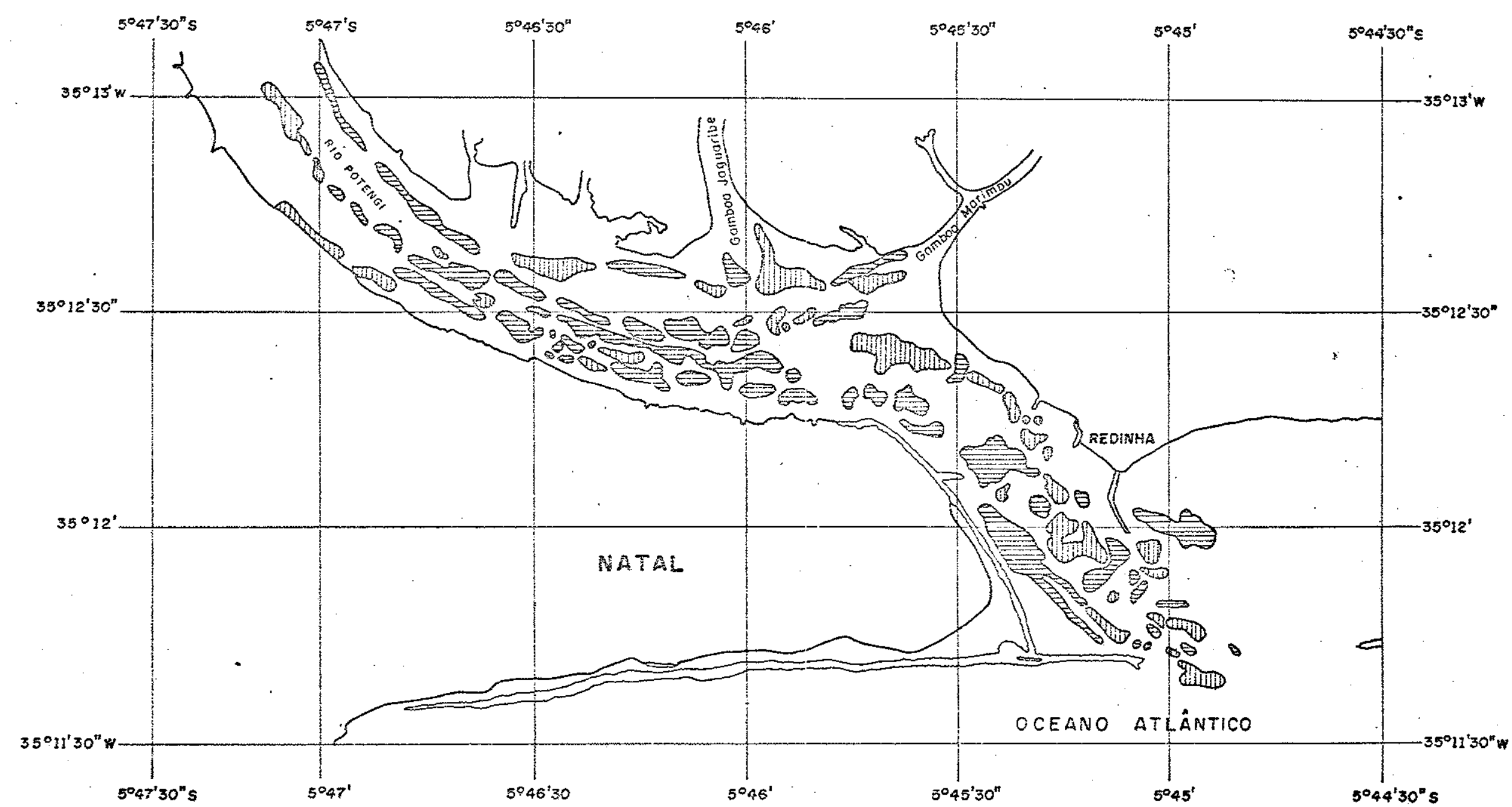

- convencöes -

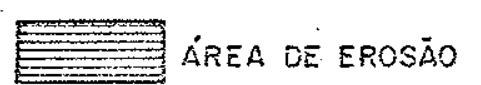

WIUUIIII ÁREA DE OEPOSIC̄ÃO

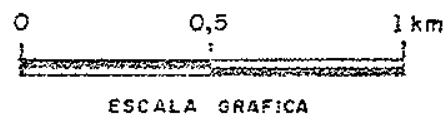

ESCALA gRAFICA
FIGURA 34 - Variações batimétricas na foz do Po tengi, entre 1941 e 1973 (FULFARO, et alii, 1578, rodif: ). 

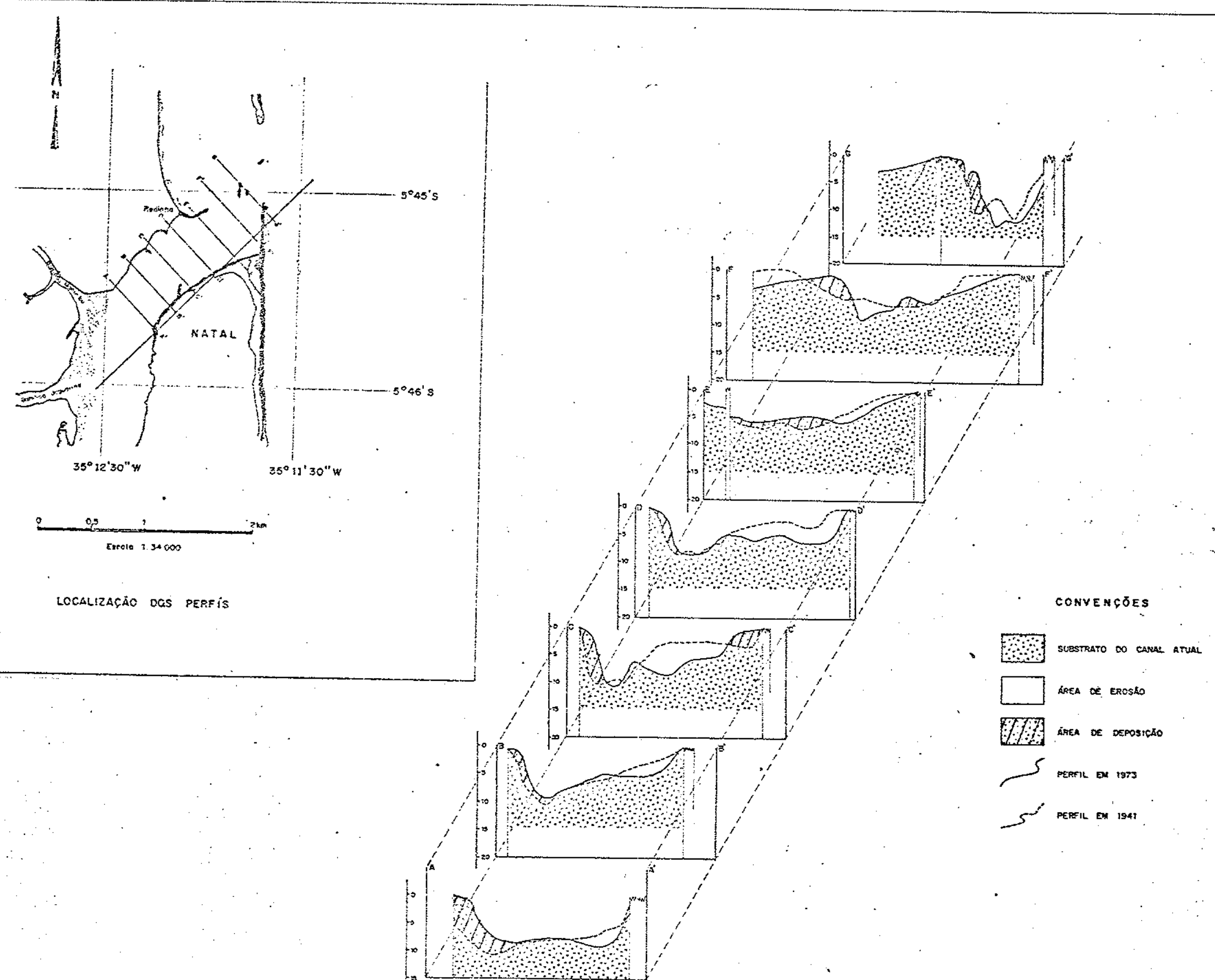

FIGURA 35 - Perfis batimétricos ao longo da foz do Potengi (FUULARO et aiii, 1978). 


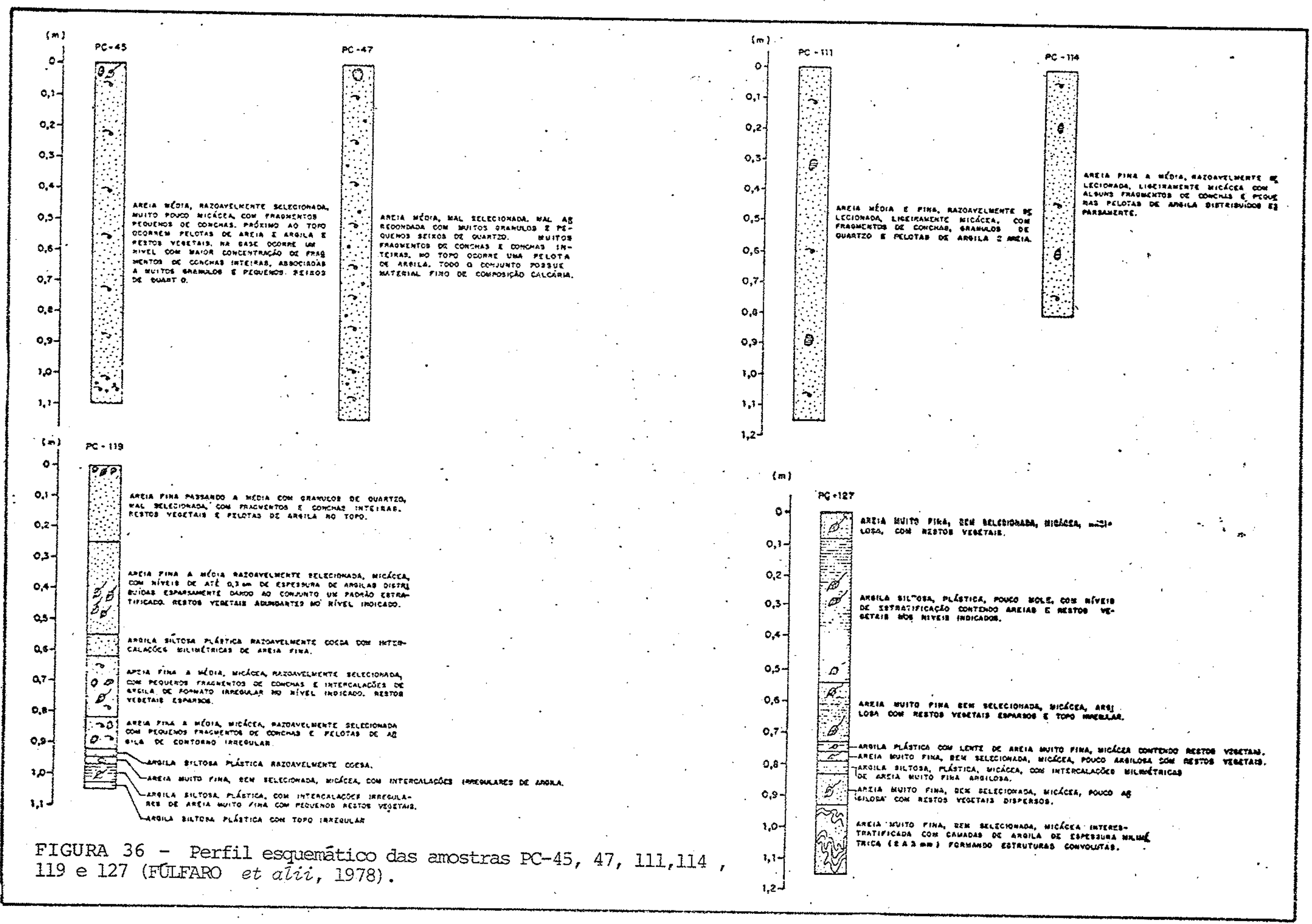

닝 

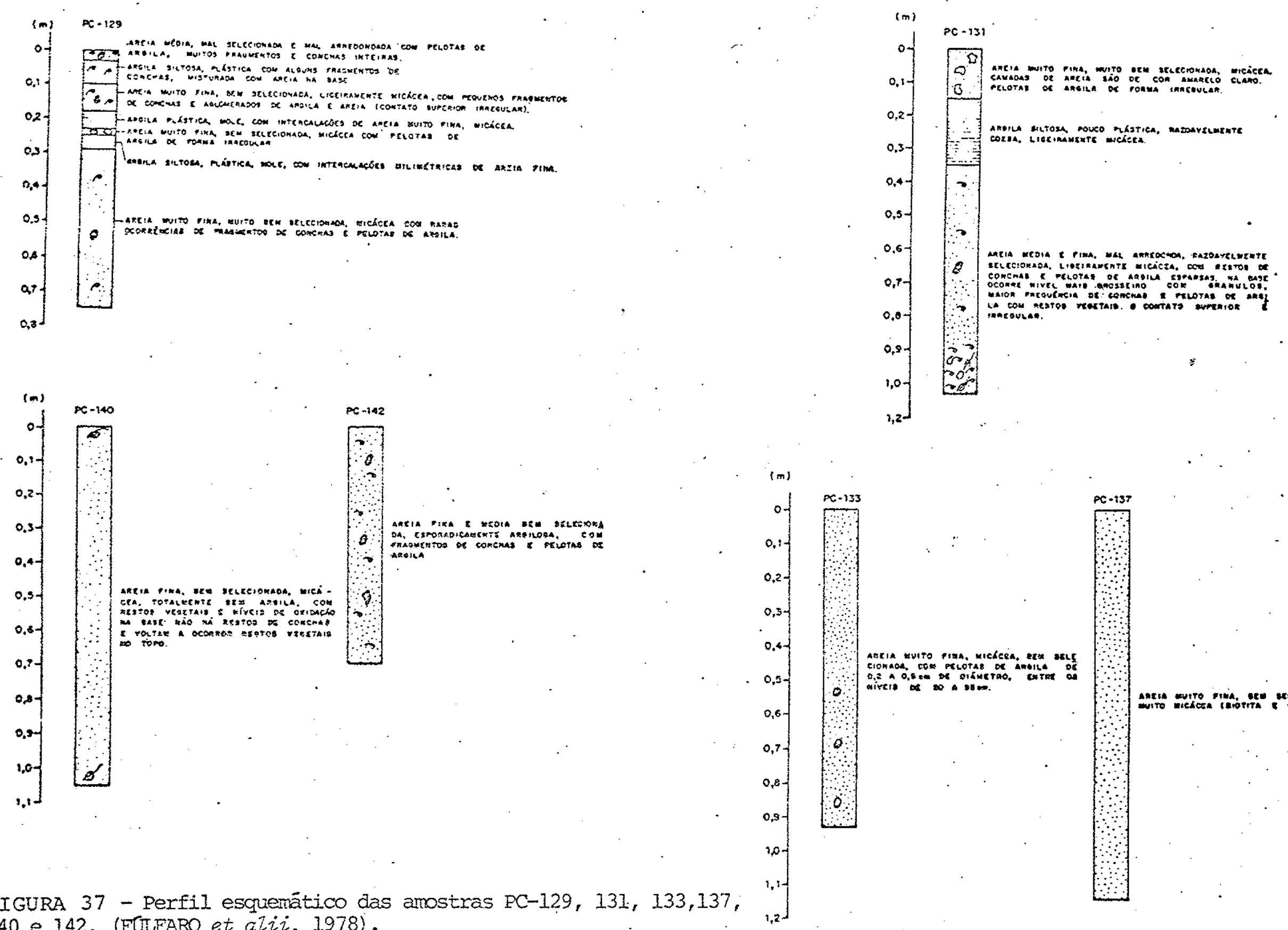

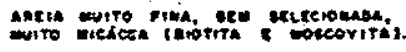

FIGURA 37 - Perfil esquemático das amostras PC-129, 131, 133,137, 140 e 142. (FULARO et alii, 1978). 

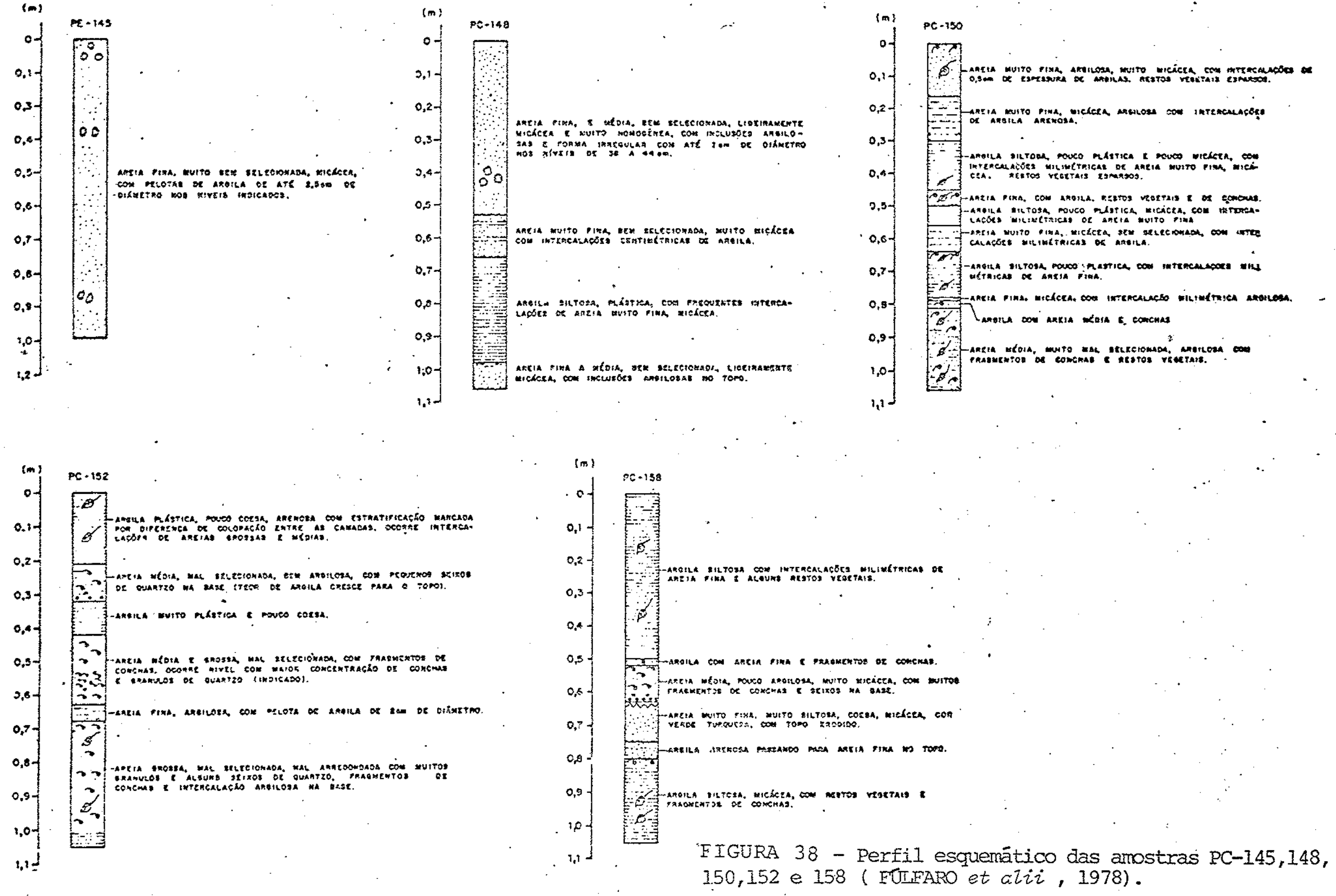
e desenvolve-se da boca da barra para sudoeste, até as proximidades da gamboa Jaguaribe. Esta zóna ē caracterizada pelas amostras PC-45, PC-111, PC-114 e PC-119."

"As três primeiras amostras mencionadas são isentas de mate rial fino, constituindo-se de areias mẻdias, sem estratificaçãovi sível, incluindo fragmentos de conchas, grânulos de quartzo, e pe lotas de argjla. Na superfucie de fundo o matexial é semelhante, indicando contjuuidede nos processos deposicionais."

"O pexfil PC-119 mostra nos primeiros 25 cm a partir do to po areias finas passando a areias medias, com grânulos de quartzo e pelotas de argila, material semelhante ao das amostras precedentemente descritas. No entanto, em djreção à base dessa amostra o correm niveis de material argiloso interestratificado com areias, sugexindo uma passagem a sedinentos mais antigos. Isto situaria a amostra pC-119 na transjeção para a segunda zona, descrita a seguix."

"A segunda zona se estende de norte da pedra do Oitizeiro até pouco a sul da gamboa Jaguariber, coincidindo com o setor mais pro fundo do estuário, e e caracterizada a partir das amostras PC-127 e PC-129, que mostran uma delgada camada de axeias finas a médias recobrindo canadas argilosas razoavelmente coesas. Essa mesma si tuação foi evidencjada pelas amostras de superficie de fundo dos pontos 126,129 e 130. Temos aqui duas fases de sedimentação to talmente distjntas, colocadas em conjunto por uma situação batimê trica especial."

"De fato, esta segunda zona do estuärio corresponde a um sulco exosivo que corta sedimentos mais antigos que os caracteris ticos da atual dinânica de sedimentação do Potengi. Assim, tem-se a exposigão de sedimentos argi.losos coesos subatuais nos baixos fun doś batimétricos, capeados por uma pelicula de areias em movimentaçäo, sendo estes ültimos sedimentos compativeis com a dinâmica sedimentax atual."

"A exposição de antigas argilas nesses fundos batimētricos explica ainda a origem das pelotas de argila, que sexiam formadas a partir do desprendimento de fragmentos argilosos coesivos, sub sequentemente rolados e transportados como clästicos grosseiros."

"A terceira zona se estende da pedra do oitizeiro até as 
proximidades das amostras 146 e 147, sendo caracterizada pelas amostras PC-133, PC-137, PC-140, PC-142 e PC-145. Os perfis dessas amostras são constituídos por areias finas e muito finas, bem selecionadas, ড̌em estratificação visível. Suas características su gerem que tenham origem eólica, tendo sido levadas ao canal do Po tengi, onde foram postexiormente retrabalhadas pelas correntes de. maré. Este retrabalhamento é documentado pelas pelotas de. argila e fragmentos de cohchas incluidos nas arejas dessas amostras."

"A quarta e ültima zona se estende para as porções mais in texiores do estuärio, e ē caracterizada pela presença de colunas sedimentares em que dominam camadas silto-argilosas, com peguenas intercalações de finas camadas arenosas, atestanäo prevalencia de ambiente de baixa energia. A amostra PC-148 seria indicativa de transiçăo da terceira para a quarta zona, enquanto que as amostras PC-150 (canal principal) e PC-158. (canal secundärio) são típicas da quarta zona."

"Na parte superior da amostra PC-152 ocorrem areias grossas e médias, mal selecionadas, e mesmo a.lguns seixós de quaxtzo, má terial sobre o qual se decanta, em superficie, material fino sil to-axgiloso. Tem-se aqui novamente, à semelhança do canal maispro fundo do estuáxio, um material heraado de fase prévia, sobrè o qual se assentaxn os sedimentos representativos da atual dinamica da sedimentação estuarina. Neste caso, o material mais grosseiro, com seixos, representa sedimentos preteritamente depositados pelo potergi, em regime fluvial, enguanto que o material silto-ajgilom so superior representa as condiçöes de circulaçäo estuarina atual, configyrando o alto estuärio do poterigi como zona de baixa enexgì."

"Nesta quarta zona deve-se levar em conta entáo que diâme tros mêdios elevados representam uma contaminação dos sedimentos representativos de superficie pelo matexial fluvial mais antigo."

"O topo da coluna sedimentar do estuärio do Potengi caracte riza-se então por sedimentos arenosos em seu médio e baixo curso, e por sedimentos mais finos em seu alto curso examos secunäarios. Isto configura para o intervalo de tempo correspondente condições enērgicas de movimentação de sedinentos por correntes de raré, como se observa ainda atualmente, propiciando a deposição de finos apenas nos setores terminais do estuärio, e gamboas associadas". 
"Na anälise dos testemunhos, variações significativas forà do padrão acima delineado parecem estar evidentemente relacionadas a depósitos prévios, não atribuíveis ao atual sistema estuari no."

"Cumpre finalmente lembrar que as areias, quase onipresentes, são abundantes tanto em áreas fonte continentais (arenitos Bar reiras e dunas), como marinhas. Neste ültimo caso é significativo notar que o primeiro setor do estuärio possui areias com diâmetros mëdios maiores que os demais setores, sugerindo entrada de material a partir da plataforma, cujo diămetro médio é mais alto, con forme descrição do $\mathrm{PC}-47$ e amostras de superficie de fundo do mar aberto."

E. Caracteristicas dos sedimentos de superfície de fundo

1. Composição granulométrica.

As caracteristicas climäticas de semi-aridez regional, que resultam en baixas taxas de fornecimento de material terrigeno pa ra a plataforma continental, aljadas a condições de altas salini dade, temperatura e transparêncịa das äguas oceânicas, favorecem - crescimento de intensa vida vegetal, principalmente algas calcá rias. Em decorrência, pode-se reconhecer na plataforma adjacente à costa potiguar duas fäcies sedimentares predominantes, uma quart zosa e outra algosa; esta ültima compõe-se em mais de $90 \%$ de algas calcärias viventes e construtivas, sendo as mais frequentes Hali meda sp. e Lithothamnium sp (KEMPF et alii, 1972).

Segundo FULFARO et alii (1978, p.90 e 91), alëm da origem autígena, "o material biodetritico possui um comportamento hidrău lico bastante diverso do material clástico terrigeno em função" das diferenças de densidade. Na granulação cascalho, por exemplo, o material biodetritico possui um valor de densidade muito inferior ao do material quartzoso equivalente, uma vez que possui uma sé-. rie de espaços vazios."

"A medida em que esse material vai sendo transportado há uma cominuição, tanto mais efetiva quanto maior o transporte, que acarreta uma dimuição dos vazios, de forma que a densidade do ma terial biodetrítico de granulação mais fina atinge valores mais elevados." 
"Com a progressiva cominuição poder-se-ia supor que certas areias calcárias finas chegassem a ter densidades semelhantes à do quartzo, ou mesmo em caso extremo de ausência de vazios, densida des superiores, pxóximas dos valores da' calcita $\left(2,72 \mathrm{~g} / \mathrm{cm}^{3}\right)$ e da aragonita $\left(, 295 \mathrm{~g} / \mathrm{cm}^{3}\right)$, que são os minerais mais comuns formado res desse material".

"Na região de Natal o material algáceo vivente e em cresci mento é um dos principais constituintes dos biodetritos, sendo co letado em geral sob a forma de pedaços centimétricos,grosseiramen te esféricos, com muito vazios. O restante do material encontrado nas amostras biodetríticas, alēm da grande variação dos espaços vazios, é constituído por clásticos das mais variadas formas, tor nando extremamente dificil e especulativa qualquer tentatjva de comparação de seu comportamento hidräulíco com os clästicos terrí genos".

"Mesmo reconhecendo-se previamente estas dificuldades, foram analisadas as caracteristicas granulométricas das amostras de com posição mista e de composiçäo biodetrïtica, a fim de se detectar um possivel padrão de comportamento do material biodetritico. Nes se sentido foram determinadas em separado as curvas de distribui ção granulométrica do material clástico quartzoso e do material. biodetrítico, sendo tambēm confeccionadas as curvas de frequência simples da distribuição quartzo e da distribuição biodetrítica".

"A anālise desses resultados mostra uma extrema dispersão e aleatoriedade com relação aos dados do material biodetrïtico, con firmando que não são passiveis de tratamento analitico...." "Este fato deve ser explicado pela origem orgânica e autígena deste ma terial biogênico, que no geral está em crescimento no pröprio 1ọ cal, fornecendo fxagmentos dos mais diversos tamanhos".

"Em virtude das Iimitações acima referidas optou-se por con siderax para fins de interpretação dos parâmetros estatíticos ape nas a distribuição terxígeno-quartzosa, uma vez que os constituin tes dessa fração possuem um comportamento hidráulico mais defini do..."."Foi ainda convencionado arbitrariamente o limite de até 50 \% de matexial terrigeno-quartzoso nas amostras que foram usadas para fins de interpretação. rodas as amostxas com menos de $50 \%$ deste material em sua composição não foram consideradas nas inter pretações dos diferentes parâmetros estatísticos". 
A rede de amostragem de sedimentos de superficie de fundo consistiu em 127 estações cobrindo parte do estuārio do Potengi, e uma porção da plataforma adjacente. Hā que se notar que esta ma Iha não cobre toda a extensão do eștuário, pois, como mencionamos previamente, formações de mangue apresentam-se ainda à altura de Macaiba. Entretanto, o limite montante da amostragem coincide com - final da porção mais larga do estuário, provavelmente seu setor de maior movimentação de sedimentos e de ãguas.

As relações entre as fácies biogênica e quartzosa bem como sua distribuição em ārea, observadas atravēs do mapa de isoporcen tagem de biodetritos mostram um padrão bastante definido ( FIGURA 39).

Os teores de material carbonático. mostram acréscimo acentua dos de oeste para leste. A zona de mudança dos teores é muito pró xima da costa junto à Ponta de Mãe Luiza, afastando-se progressivamente para norte. A ampliação da ärea de domínio dos terrígenos é acompanhada por um maior espaçamento entre as curvas de isoteor justamente a partir da barxa do potengi, evidenciando claramente a contribuição de material clástico oriundo do sistema Potengi/Jun diai.

Com relaçäo aos sedimentos da fácies quartzosa, o mapa de distribuj.̧ão de diâmetros médios mostra no setor de mar aberto uma ampla distribuição de sedimentos arenosos (FIGURA 40).

Ao longo da cidade de Natal ocorre uma faixa de areias gros sas a muito grossas cujo limite leste ë provavelmente condicionado pela corrente que propicia o desenvolvimento das colonias de algas.

Junto à Iinha de costa, entre a Ponta de Mãe Luiza e o For te dos Rejs Magos, encontram-se faixas de areias finas e muito fi nas, que dão lugar a areias médias, em faixa que se amplia e se alarga para norte, dominando toda a zona da barra do potengi. Jun to à entrada da barra uma faixa de areias grossas interrompe o do minio de areias médias.

No interior do estuärio dominam sedimentos arenosos finos, encontrando-se material mais fino apenas na desembocadura de gam boas, associado ao crescimento dos mangues, e mais para o. interior, jă no alto estuáxio, onde decresce consideravelmente a movi mentação das āguas. 


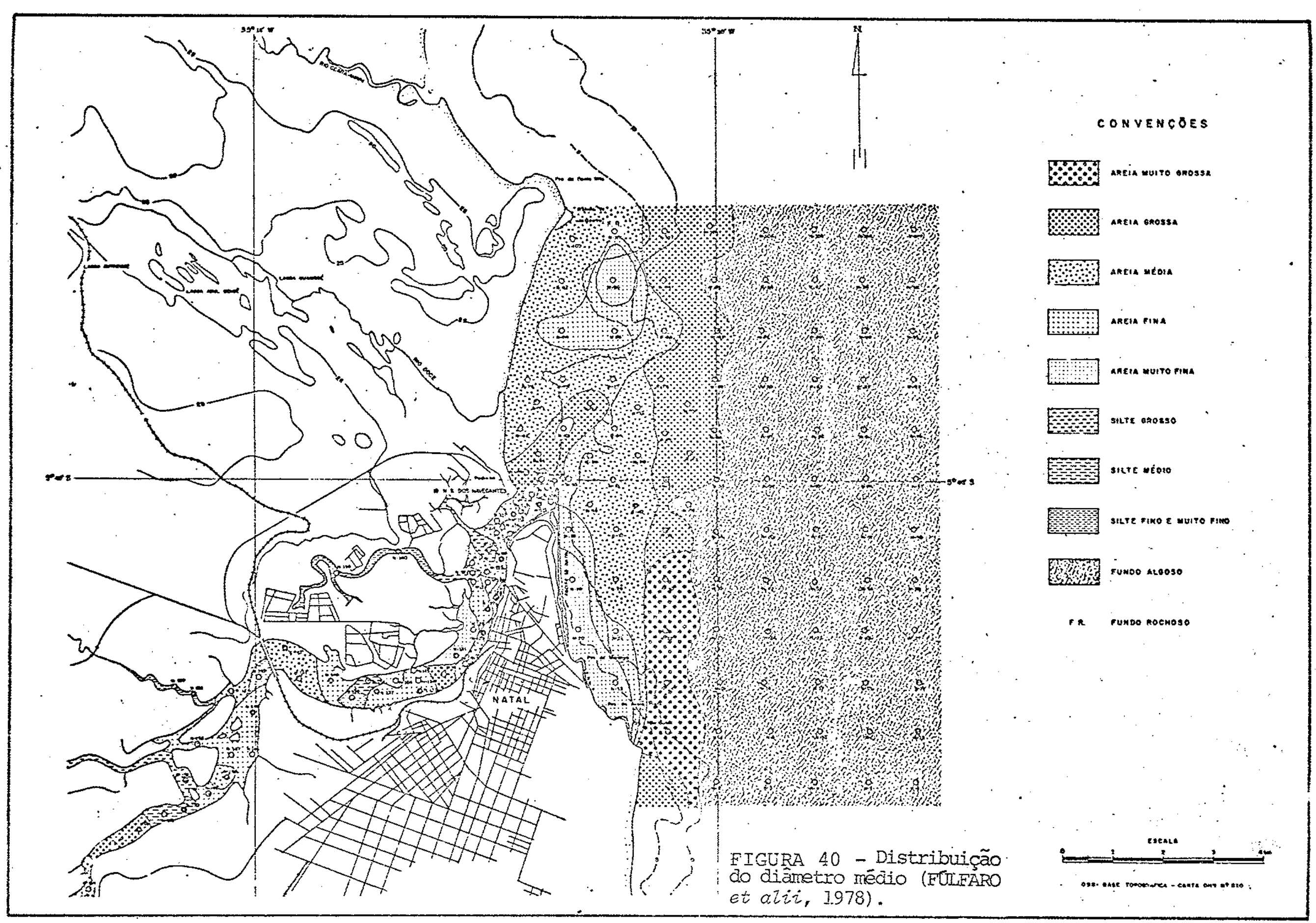

$\stackrel{5}{\circ}$ 


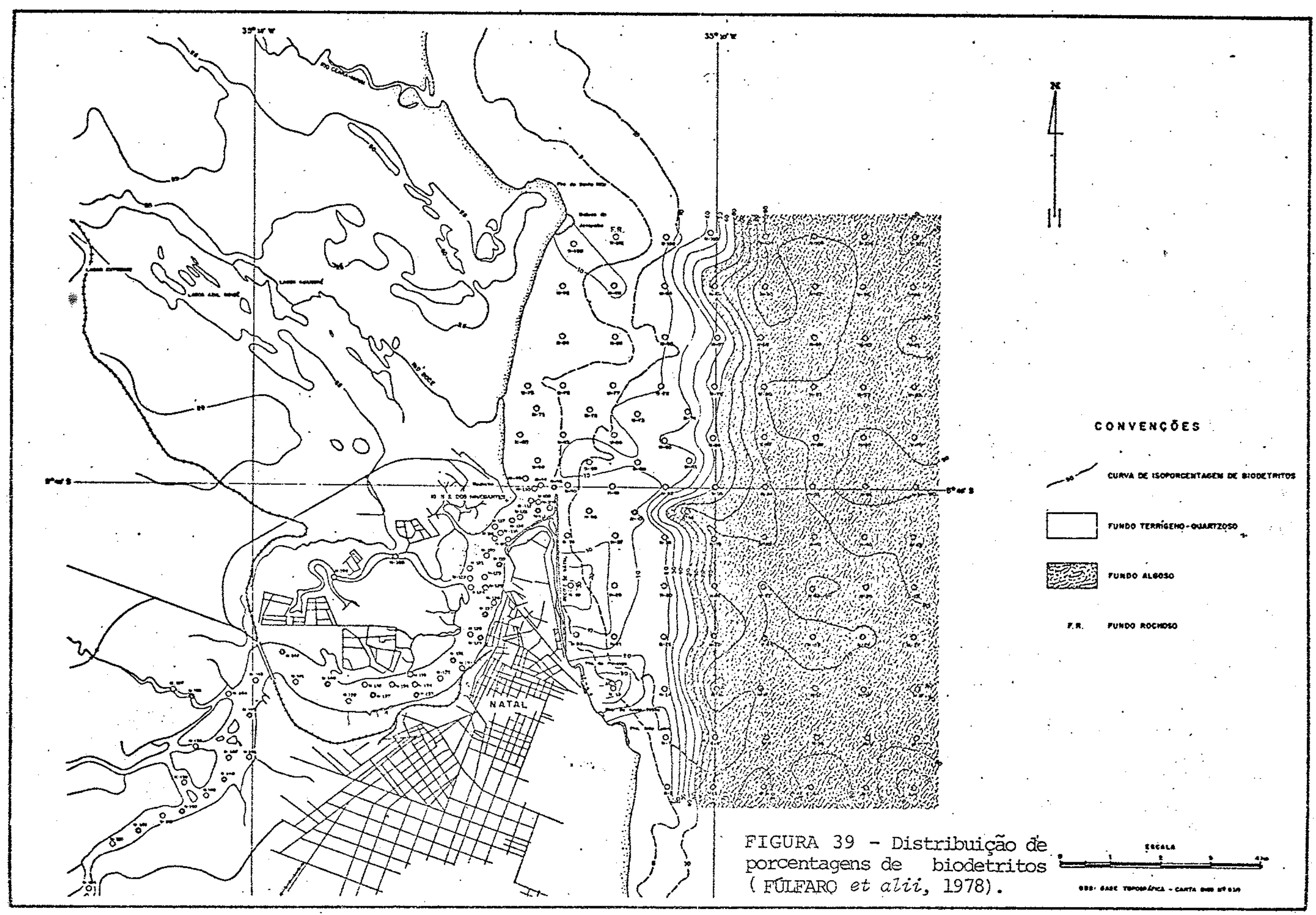

$\stackrel{5}{w}$ 
As areias médias e grossas encontradas na porção terminal do estuário e junto à saída da barra podem ser atribuídas a trans porte de fundo barra adentro a partir das arejas mais grosseiras encontradas na plataforma. Essas areias adentrariam a barra por correntes de enchente ou ainda em condições tais que a corrente costeira oscilasse em direção ao continente.

Por outro ladọ, a zona de areias finas encontradas a sul da Ponta de Santa Rita poderiam ser atribuídas a contribuição de ma terial mais fino provenientes do sistema Potengi/Jundiai.

Tal distribuição de sedimentos de fundo sugere, no estuário do Potengi, domínio de movimentação de sedimentos por correntes de maré, permitindo a movimentação de sedimentos arenosos até as pro ximidades da estação 147. Só a partir daî decresce consideravel mente a movimentação, ocorrendo a deposição de material mais fi. no.

- mapa de distribuição do grau de seleção mostra no setor de mar aberto a noxte da baxra, incluindo a saida do potengi / Jun diaj, sedimentos moderadamente selecionados (mICURA 41). n sul da barra,bordejando a costa, encontra-se uma faixa de sedimentos mui to bem e bem selecionados, gue devem estar relacionados ã zona de dominio dos processos.costeiros.

Para o interior do estuário dominam fundos de material mode radamente selecionados, encontrando-se sedimentos pokremente $e$. muito pobremente selecionados apenas nas partes mais interiores ( alto estuário). As anomalias de material bem e muito bem sele cionado que ocorrem no interior do estuário devem-se provavelmente, a contribuições locais de material de origem eólica com caracte risticas originais de born selecionamento.

A distribuição de assimetrias (FIGURA 42) mostra predominio de valores negativos na maior parte do estuärio e plataforma. con tinental, o que considéramos indício de atuação efetiva tanto duas correntes de marē, como costeira, na remoção dais frações mais fí. nas dos sedimentos de fundo. Sob essa mesma ótica, a porção mais a montante do estuārio, com assimetrias positivas, seria indicati va de ambiente menos enërgico. A faixa de assimetrias positivas que se estende defronte à zona de fundos algosos, e se prolonga em di reção à barra do potengi, poderia ser indicativa de população cá racteristica do limite leste da corrente costeira. 


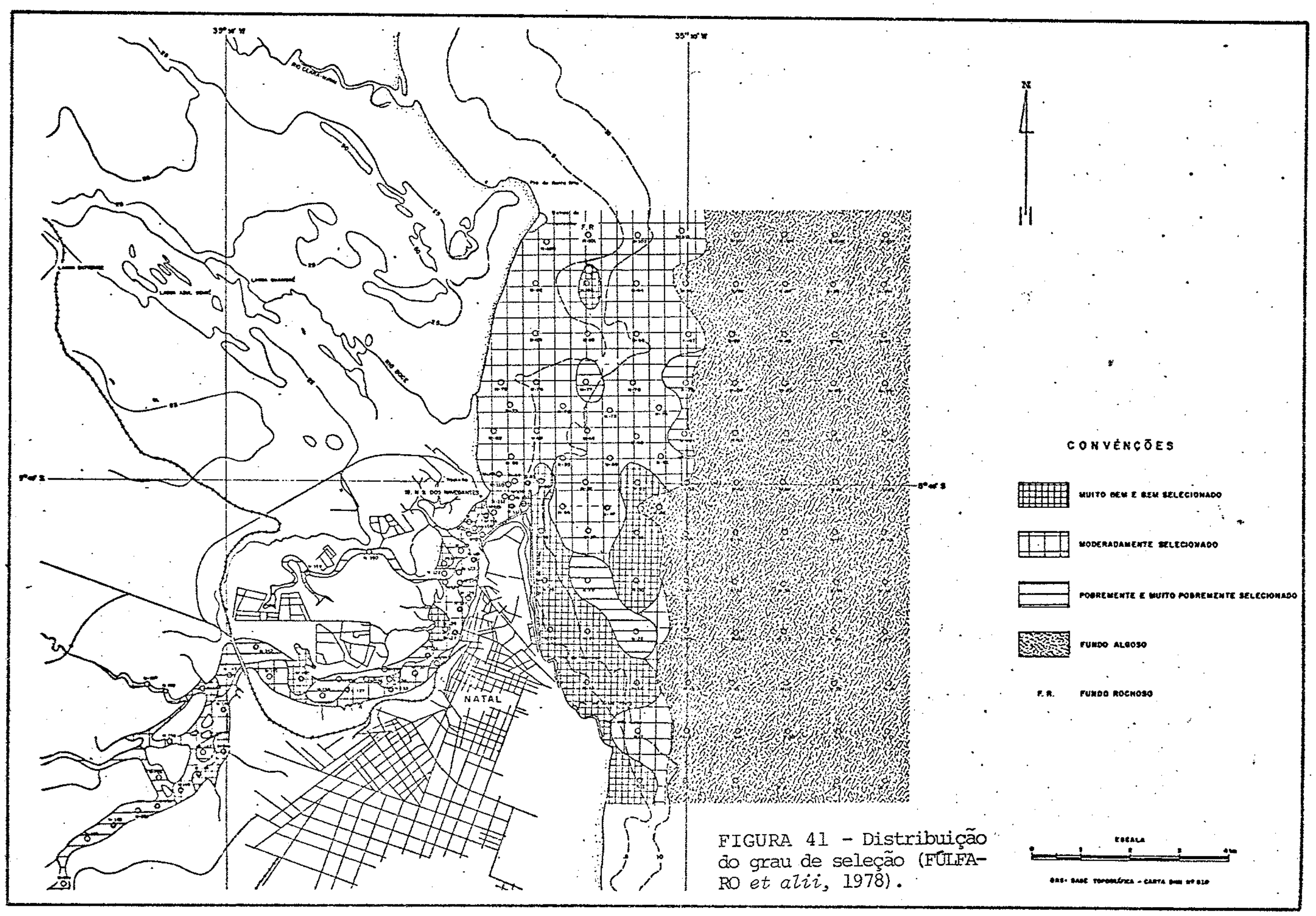

$\stackrel{\omega}{\omega}$ 


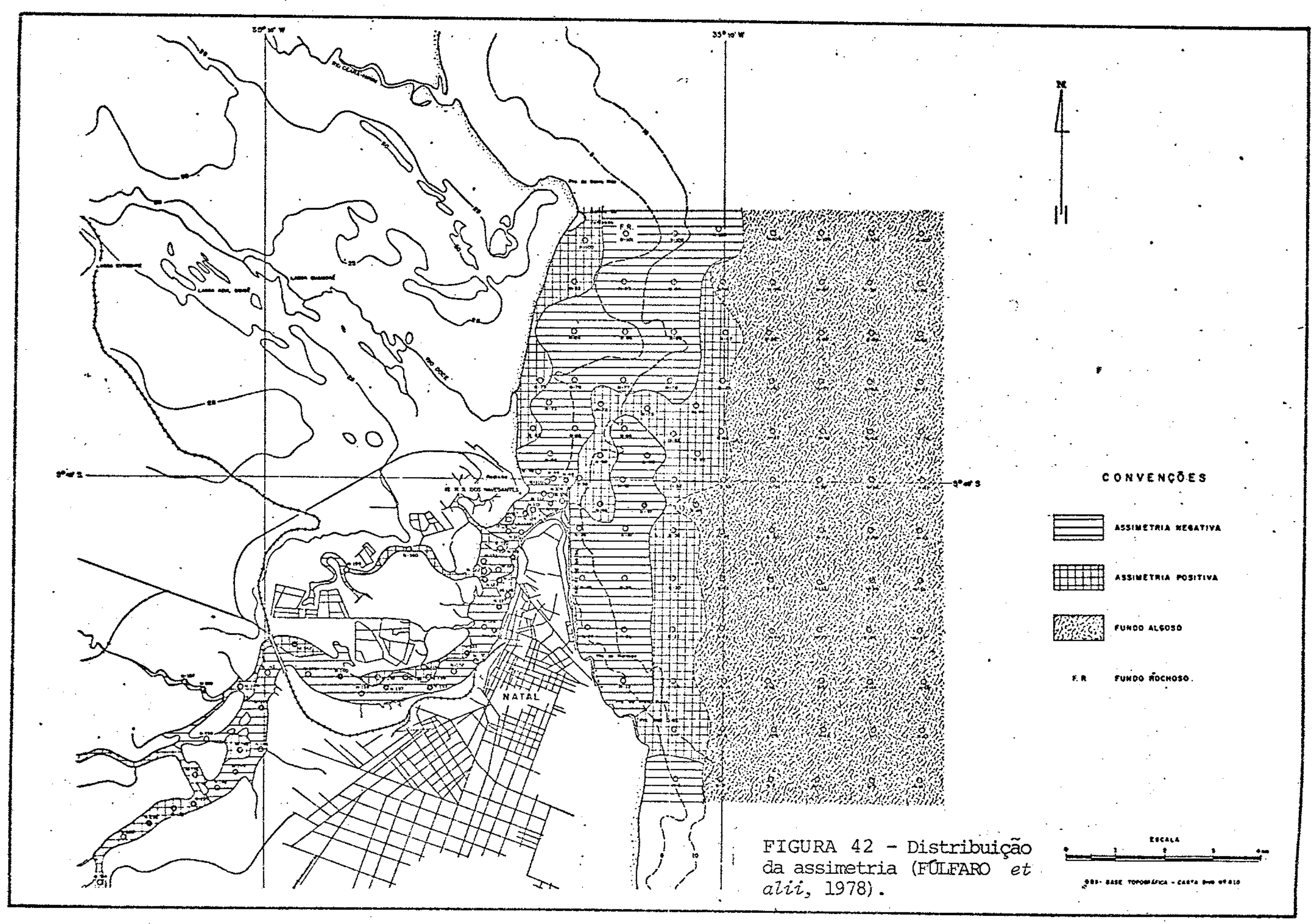

$\overrightarrow{5}$ 
No que se refere à curtose (FIGURA 43) predominam distribui ções leptocúrticas e muito leptocūrticas no estuärio e na platá forma. Podemos interpretar que esses valores sugerem populações com modas bem definidas, o que seria indicativo de área-fonte uni ca, ou de efetivo processo de seleção. Considerando a exposição procedente, parece-nos esta última a melhor hipótese. Nesse sentido, a faixa de sedimentos mesocürticos, platicürticos e muito platicürticos ao longo das praias, poderia ser entendida como re gião de mistura de sedimentos de origens diversas, por transporte li.torâneo.

A distribuição do diâmetro méđio da fração areia evidên cia também um decrēscimo de energia em direção ao interior do estuário, especialmente a partir da desembocadura da gam boa Jaguaribe, passando as areias médias de junto da barra para areias finas e muito finas mais para o interior. No entanto per siste em quase todo o setor investigado do estuārio, energia sufi ciente para movimentação de matexial arenoso.

\section{Composiçäo mineralógica}

Buscando verificar as relações entre as amostras através de método independente das classificações texturais, procedemos à análise de 68 amostras regularmente distribuidas na malha de amos tragem.

Através de análise de agrupamento realizada com os resultados de frequência dos minerais pesados foi possivel subdividir a área de interesse em setores bem definidos caracterizados por gru pos de amostras distintos (FIGURA 44). Os värios grupos de amostras correlacionáveis entre si permitiram a delimitação de três setores: o setor do estuário, o setor de mar aberto mais pröximo da costa situado a norte da barra, e orestante do setor de mar aberto incluindo a poxção costéira a sul. da barra. Esses resultados vêm de encontro às considerações tecidas com base nas inter pretações sobre a distribuição do material de supertície de fundo. o setor do estuário é caracterizado por amostras com elevado coe ficiente de correlação, similares às que ocorrem também no se tor de mar aberto a norte da barra. O restante da área de mar aber to é caracterizado por amostras exclusivas desta ärea, que, entre tanto, ocorrem também na porção tèrminal do estuário, mostrando 


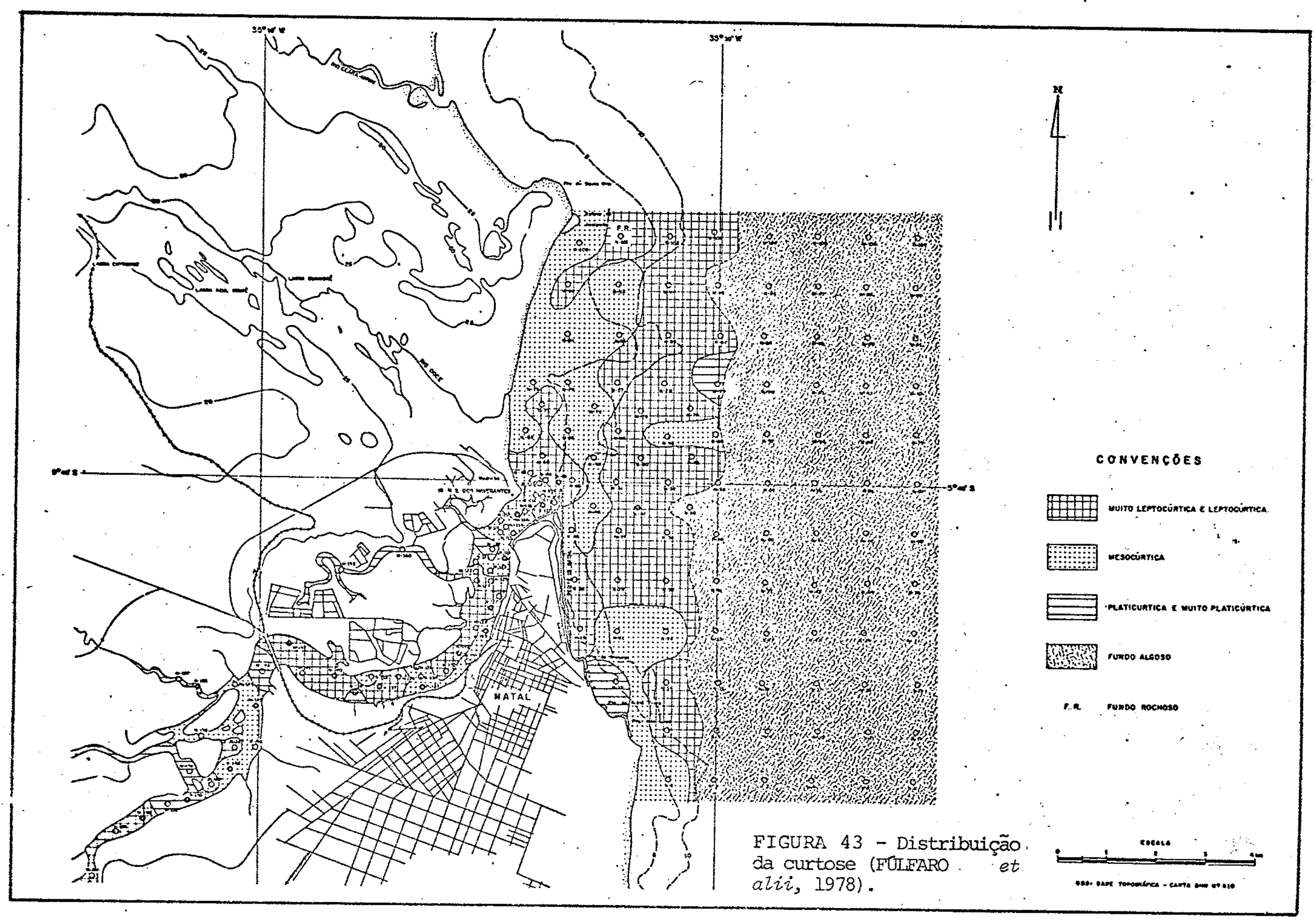




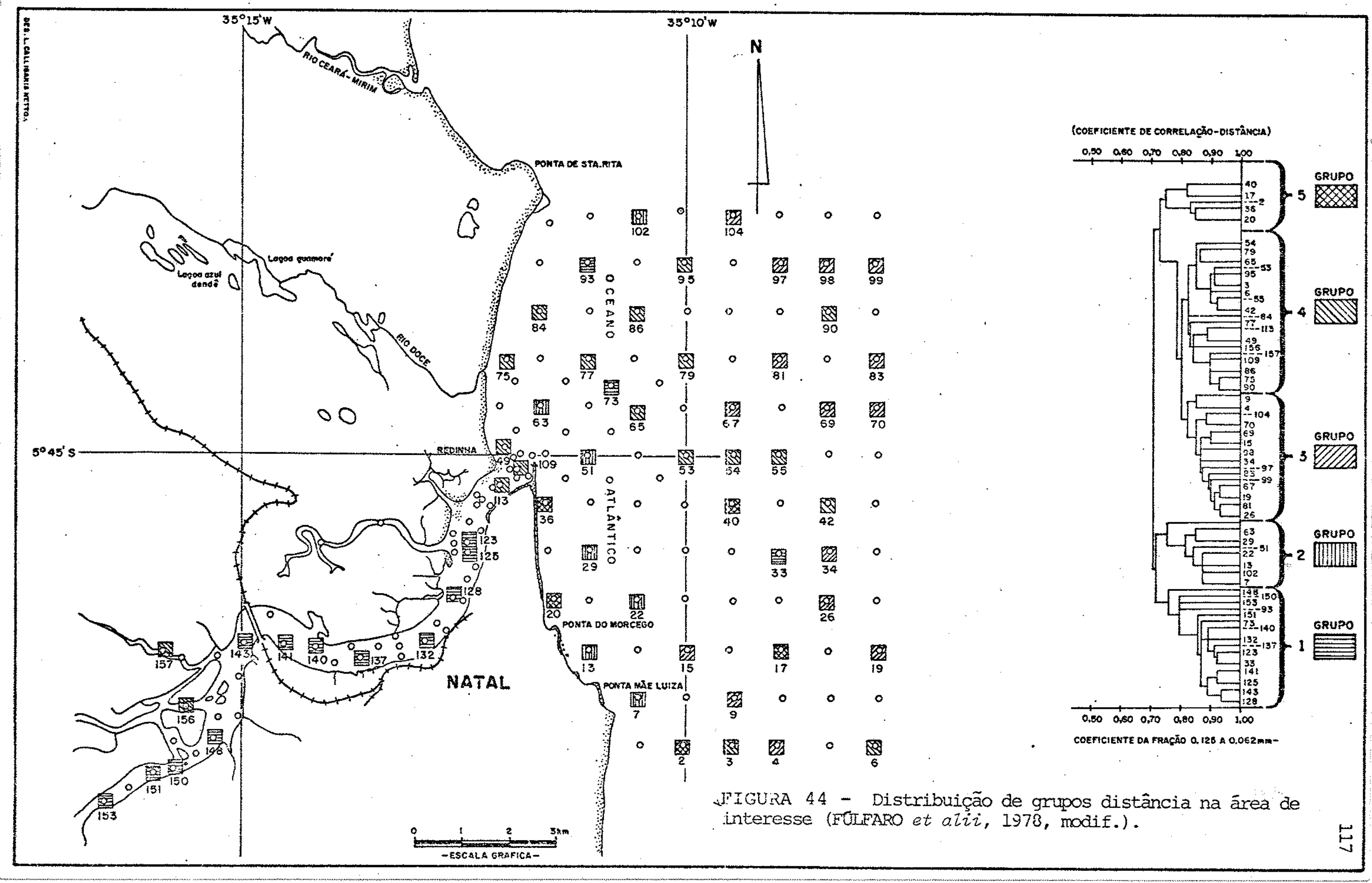


claramente a entrada de material oriundo da plataforma para o in terior do estuário.

F. Sintese da dinâmica sedimentar atual

Segundo FULFARO et alii (1978, p.97 e .98) "pode-se caracterizar o sistema Potengi/Jundiaí como um estuário de equilíbrio re cém adquirido, balizado por uma soleira rasa em sua entrada".

"Os principais modos de circulação d'āgua que atuam . nessa área são comandadas por uma corrente costeira sul-norte, que pas sa nas proximidades da costa de Natal, e por correntes originadas pelas marēs, que adentram e saem do estuário".

"Esses fatores, em interação com a morfologia do estuário, condicionam a sedimentação subaquātica".

"Assim, na zona de dominância da corrente costeira há condi ções propícias à formação de fundo algoso, que transicionam em dị reção à costa para material terrígeno-quartzoso".

"Por outro lado, na movimentação de äguas estuärio adentro, há um aporte de material terrigeno-guartzoso mais grosseiro prove niente de mar aberto, que é acumulado na parte interna da barra. Para o interior do estuārio, domínio de correntes originadas por marés, começam a depositar-se sedimentos de granulação sucessiva mente mais fina, chegando a uma fácies silto-argilosa no alto es tuário. Este quadro pode por vezes ser nascarado por contribuiçóes laterais de material detritico, ou material herdado de fases mais antigas".

"Num movimento de saída de correntes, tem-se movimentação e deposição de material mais fino e restos vegetais, provenientes do interior do estuário, em direção a mar aberto. Este material è le vado barra afora, caracterizando uma região de sedimentos mais fi. nos a norte da barra do Potengi/Jundiai. Neste caso a soleira fun ciona como elemento de retenção do material mais grosseiro trans portado por tração. A deposição dos finos em mar aberto por sua vez faz-se para norte por comando da corrente costeira".

"As gamboas são braços secundários de circulação no interior do estuārio, e constituem palco de sedimentação mais fina".

"Com exceção de pequenas contribuições laterais ao longo do estuärio, pode-se considerar que os processos sedimentares se fa 
zem a partir de material subaquático, já que os campos de dunas a sul do. Potengi/Jundiai encontram-se atualmente estabilizados".

"Vale salientar que o mecanismo de circulação d'äguas pode mudar de acordo com a maior ou menor proximidade de corrente cos teira da linha de costa, "bem como com eventuais variações sazonais do dēbito do Potengi/Jundiaí. Essas variações induziriam a modificações na distribuição das făcies dos sedimentos de superfí cie de fundo, podendo originar um quadro de distribuição sedimentar não necessariamente coincidente com o obtido através das amos tras coletadas para este trabalho".

"A dominância da circulação marinha no estuärio do Potengi/ Jundiaí, aliada à grande disponibilidade de materiais detriticos, leva a prever que modificações naturais ou artificiais nos modos de circulação d'ãgua terão reflexos notāveis na razão erosão/depo sição no interior do estuārio, com alterações da distribuição das fācies sedimentares de fundo, e consequentes alterações batimétri cas".

Com relação à corrente costeira, gostaríamos de salientar que seu sentido foi inferido por condiçōes morfológicas, e sua fai xa de atuação é delimitada pelos fundos algosos. Adicionalmente, consideramos que a faixa de atuação da corrente costeira, essa corrente de uma só margem, na feliz expressão de BLANC (1982), pô de ser melhor definida com o auxilio da distribuição dos parâme tros estatísticos granulomëtricos, e dos conjuntos de minerais pe sados.

No que se refere à classificação do estuário, consideramos que seu enquadramento no tipo de soleira rasa (FULFARO et a $i$ i , 1978), embora tenha relação com a morfologia do potengi, em cuja foz efetivamente se encontra uma barreira (grandemente derrocada) representada por restos de recife, pode induzir a uma avaliação não muito apropriada da circulação estuarina. Esta, parecemnos do minada por correntes de marë, sendo pouco provävel a existência de água salgada estagnada em sua porção basal. Ássim, levando em con ta o porte do potengi/Jundiaí, bem como o clima regional, parecenos mais provävel que o estuärio seja do tipo verticalmente homogêneo ou estratificado com mistura vertical. E possível, aliās. que esses dois tipos se apresentem conforme a vazão do rio. 


\section{ESTUARIO SANTISTA}

o Porto de Santos situa-se em unidade fisiogräfica bem defi nida, conhecida como Baixada Santista, objeto de numerosos estudos, entre os quais a extensa monografia organizada por AzEVEDo (1965).

o estuário em que se acha implantado o porto mereceu estudos setoriais realizados por pesquisadores do Laboratório de Hi dráulica da EPUSP/DAEE (EPUSP/DAEE, 1966). Durante a década de 60, diversos outros estudos de sedimentação em ambientes subaquáticos costeiros foram realizados no Estado de São Paulo, embora não apli cados a portos (KUTNER, 1962, 1963; MAGLIOCCA \& KUTNER, 1964, 1965) ; os trabalhos dessa época, foram revistos por KUTNER (1976).

A partir de 1973 em diversas campanhas, tivemos a ncasião de desenvolver estudos nessa área, parcialmente publicados (FULFA RO \& PONÇANO, 1976; FULFARO et a $i$ i , 1976; PONÇANO \& FULFARO, 1976). Em nossos trabalhos, usamos uma abordagem que privilegiou a formu lação de um modelo de sedimentação atual para todo o estuário,con siderando que "a sedimentação estuarina è o resultado da influên cia de processos tanto continentais, quanto marinhos, que se in terferem, produzindo um padrão complexo. Assim sendo, o estuário foi estudado dentro de uma unidade geomorfológica natural, que é a Baixada Santista, levando-se ainda em conta que as influências marinhas seriam esclarecidas considerando-se a baía de santos co mo elemento físico complementar" (FULFARO \& PONÇANO, $1976, \mathrm{p} .67 \mathrm{e}$ 68). A rede de amostragem abrangeu 256 estações de coleta de amos tras compreendendo estuário e baĩa, na campanha bāsica de 1973.

Procuramos a seguir sintetizar os resultados obtidos atra vés da abordagem acima mencionada.

\section{A. Geologia}

A Baixada Santista compreende um complexo de terrenos sedi mentares quaternārios, limitados, pelo lado continental, por ro chas precambrianas, que ocorrem ainda no interior da Baixada San tista, sob a forma de morros circundados pelos sedimentos da pla nície costeira. Essa região acha-se limitada por dois amplos aci dentes tectônicos que são a Bacia de Santos e a Serra do Mar.

A Serra do Mar teria sido formada durante a fase de tectôni 
ca rígida cretācico-terciária que afetou a Plataforma Brasileira, cujos reflexos se estenderam talvez até o início do Quaternārio (FREITAS, 1951; ALMEIDA， 1967，1976; AB'SABER，1969).

As áreaś precambrianas são formadas por um complexo de mig. matitos e rochas graniticas associadas, orientados segundo N45-50E, concordantemente com a Direção Brasileira de dobramentos, com mex gulhos fortes, próximos da vertical; estas rochas encontram-se cor tadas por uma zona de falha, que acompanha aproximadamente os va les dos rios Cubatão e Mogi (BISTRICHI et alii, 1981). As rochas precambrianas acham-se ainda cortadas por diques de diabāsio; re lacionados à fase tectônica cretácico-terciária.

o reconhecimento geológico de superfície levou à subdivisão dos terrenos da Baixada santista em três grandes grupos, no que diz respeito à natureza de seus depósitos detríticos:

- Depósitos de mangue

Correspondem a sedimentos argilo-siltosos, com abundantes restos orgânicos. Localmente podem estar capeados por len çöis descontínuos e rasos de areias marinhas..

- Aluviões e coluviões

Aluviões atuais e subatuais (terraços) são predominantemente arenosos em superfície, mostrando em algumas seções ao longo de rios (Cubatão, Mogi e Diana, por exemplo) len tes de argila e cascalho. Estes sedimentos são geralmente imaturos, passando por vezes a depósitos coluvionares fi nos, como se nota em especial na cabeceira do rio Diana.

- Antigos depósitos marinhos

Correspondem a antigas praias e sedimentos de mar raso da Formação Cananéia, e a terraços marinhos pós-glaciais.são predominantemente arenosos, bastante maturos, . ocorrendo comumente concentrações de conchas nos depösitos de mar raso.

- reconhecimento e cartografia désses depósitos foram apresentados por SUGUIO \& MARTIN $(1978 a, b)$. A partir dos dados de sonda gens executadas pela Geotécnica S.A. em 1968 na Baixada Santista procuramos estabelecer os principais traços da estratigrafia da 
Baixada, referente aos sedimentos de subsuperfície, como segue. Os depósitos de subsuperficie mostram uma sequência sedi mentar caracterizada por uma sucessä́o de camadas conglomeräticas na base, seguidas por camadas de argila, e arenitos conglomerāti cos, comumente lenticulares. Esses depósitos parecem integrar um complexo fluvial de piemonte, com depósitos arenosos mal classifi cados, interdigitados com argilas cinzentas evidenciando planicies de inundação fluvial. Em direção às montanhas passar-se-ia a leques aluviais com conglomerados de matriz argilosa, que geral mente aparecem na base dos depósitos. A estes leques aluviais atri buimos idade sincrônica à do último evento glacial. (MELO \& PONÇA NO, 1983).

A distribuição e profundidade das sondagens mostram ainda que o substrato apresenta topografia irregular. Não obstante, a inclinação dos vales do Quilombo e o Jurubatuba dá valores em tor no de 19 para o gradiente fluvial correspondente à base dos depó sitos sedimentares. Tomando por espessura mëdia para os mëdios cur sós desses rios un valor em torno de $30 \mathrm{~m}$, poder-se-ia esperar es pessuras de sedimentos da ordem de $60 \mathrm{~m}$ na área ocupada pela cidạ de de Santos, o que, de fato, ocorre.

Os fatos acima expostos sugjerem que as fases francamente ma rinhas correlatas aos depósitos sedimentares encontrados em subsuperfície na região da Baixada Santista encontram-se bem distan tes, plataforma continental atual adentro. Atẻ Santos, a partir da serra, ainda são encontrados depösitos nitidamente fluviais, em várias fases de reentalhe, que podem ter tido uma origem múltipla: tectōnica, eustātica e climātica. A última transgressão marinha, pós-glacial, recobriu esses depósitos com uma delgada camada sedi mentar.

o recuo da linha de costa do último periodo transgressivo para sua posição atual teria desencadeado o processo de desenvol vimento da extensa região de manguesais da Baixada Santista.

A formação de manguesais, bem como a cobertura de sedimen tos reliquiares da plataforma são fatores dos mais importantes pa ra a compreensão da dinâmica de sedimentação no éstuário santista, como será discutido mais adiante. 


\section{B. Geomorfologia}

- Iimite continental da Baixada Santista corresponde às en costas abruptas. frequhentemente côncavo-convexas da Serra do Mar. Estas encostás são cortadas por uma rede de drenagem essencialmen te adaptadas às linhas estruturais, ao longo da qual se organizam planicies aluvionares, terraços, cones de dejeção de torrentes e pequenos deltas.

A Baixada Santista propriamente dita corresponde a uma com plexa planície costeira que engloba praias, planícies de maré,pla nicies aluvionares,e planícies de antigos sedimentos marinhos. Ain da na Baixada Santista, isolados por sedimentos da planície cos teira, dispõem-se morros de rochas precambrianas, de encostas se melhantes às da Serra do Mar. Estes morros podem fazer face direta ao mar, o que resulta na formação de costões e de pequenas praias de tombo.

A passagem das encostas de rochas precambrianas à planície costeira é geralmente abrupta, podendo ser feita, não obstante, de mòdo mais suave, por interméaio de aepósitos coiuvionares (rampas de colúvio, talus) e aluvionares (cones de dejeção), dispostos em muitos locais ao longo do sopé da Serra do Mar.

Os traços essenciais da evoilução geomorfológica da Baixada Santista foram descritos por AB'SABER (1965), cujas conclusões podem ser algo alteradas pelos trabalhos de SUGUIO \& MARTIN (19.78a, b) e MARTIN et alii (1979a).

A exposição de AB'SABER (1965) mostra que dois fatos balizam a evolução geomorfológica da ärea em foco: o tectonismo cretá cico-terciário e a transgressão flandriana, que sUGUIo \& MARTIN (1978b) denominaram Transgressão Santos.

Assim, a serra do Mar, limite continental da Baixada, teve sua origem em falhamentos que se processaran no Cretáceo e Terciá rio, concomitantemente a um levantamento epirogênico continuo, que afetaram essa região (AB'SABER, 1965). Estando o mar de 80 a $100 \mathrm{~m}$ abaixo de seu nível atual, processaram-se o entalhamento e alarga mento de vales (AB'SABER, 1965), os principais dos quais obedeciam fundamentalmente a Direção Brasileira de dobramento ( que ė também a direção de importantes falhamentos), como exemplifica a forma alongada segundo NE das serras de Santo Amaro e Guararu, na 
ilha de Santo Amaro, bem como a configuração dos interflúvios dos rios Diana, Quilombo e Jurubatuba, que recortam a planície costei ra.

Nesse péríodo de rebaixamento do nivel marinho, correponden te à glaciação würm, teriam sido tambēm entalhados os sedimentos depositados no interglacial Riss-Wurm em cujo topo colocam-se as areias da Formação Cananéia.

A subida do nível marinho a pouco mais de cinco metros aci ma de seu nível atual, no máximo da Transgressão Santos, com con seqüente inundação dos vales formados e alargados na fase anterior, levou à formação da páleo-baía de Santos, que continha o pāleo-ạ quipélago de Santos, formado por interflúvios insulados de antí gos vales (AB'SABER, 1965).

Em seu recuo para a deposição que hoje ocupa, o mar teve dois momentos de still stand, aproximadamente a $5 \mathrm{~m}$ e a $2 \mathrm{~m}$ (MAR TIN et alii, 1979), constituindo terraços marinhos.

Assim, para AB'SABER (1965) os diferentes níveis de planí cie costeira santista seriam explicados pelos eventos pós-glaciais de oscilação marinha, ao passo que os conhecimentos mais recentes indicam que o nível correspondente à Formação Cananéia é pleistocênico.

Feições subordinadas de antigos alinhamentos de praias são comuns às diferentes setores de planície da baixada. Menos co muns, porém mapeáveis, são concentrações de areias em terraços, marcadas por tênues lineações com formas sugestivas de atuação de correntes marinhas; sua principal ocorrência está na região de Ví cente de Carvalho, Ilha de Santo Amaro.

A ação fluvial processa-se diferentemente, e de acordo com as características topográficas e litológicas das āreas em que atuam. Desta forma, as torrentes serranas escavam vales em "V", de vertentes ingremes, aos quais se associam depósitos de calha e pequenos cones de dejeção, que contêm grande proporção de blocos e matacões. Os rios provenientes de terrenos precambrianos trans portam, em seu percurso na serra, sedimentos de granulometria va riada, incluindo clásticos grosseiros; no sopé das encostas a fração mais grosseira deposita-se rapidamente, continuando a se rem transportados principalmente areia e sedimentos mais finos. A eșta mudança de competência superpõe-se uma mudança no modo de es 
coamento desses rios: seus percursos, de bastante retilineos e controlados por direções estruturajis, passam a ser meandrantes.Já os rios que naścem na Baixada têm percursos meandrantes, cortando apenas áreas da planície costeira formadas por depōsitos detrîticos arenosos e mais finos. Vale ainda notar que muitos rios so frem influência das marēs na quase totalidade de seus percursos, como é o caso dos rịos Mariana e piaçabuçu. Formas importantes li gadas a processos fluviais são os pequenos deltas que parecem es tar se formando transgressivamente sobre manguesais, dos quais os exemplos mais notáveis são os dos rios Cubatão e Mogi.

$\mathrm{Na}$ região de interação mais direta entre ãguas continentais e oceântcas, nas proximidades das desembocaduras dos rios nos lar gos da Baixada, colocam-se bancos de areia e coroas submersas. Es tes depósitos de sedimentos têm forma variāvel, e são produtos da perda de velocidade (competência) dos fluxos transportadores, de barramentos naturais provocados por correntes e, possivelmente, por mudanças de condições químicas das āguas.

As encostas de rochas pré-cambrianas caracterizam-se peia formação de regolitos espessos, graças ao intenso intemperismo químico. A evolução destas encostas se faz por processos de remo ção rápida (escorregamentos) e lenta (rastejo) de solos, resultan do na formação de rampas de colúvio, talus, e āreas de exposição de rocha.

Restạ finalmente lembrar que a crescente urbanização e in dustrialização da Baixada tèm interferido diretamente nos equilí brios fito-pedo-morfológicos naturais. O principal resultado da atuação antrópica tem sido acelerar os processos de remoção de so los, seja com a construçãa de rodovias, ferrovias e núcleos habi tacionais no sopē e encostas da Serra do Mar, seja pela elimina ção de vegetação e terraplenagem extensiva em áreas da planície costeira. Alēm disso deve-se salientar a possibilidade de mudança das condições quimicas das äguas superficiais, pelo lançamento de detritos industriais, fato que viria causar àlteraçōes na ảinâmi ca de deposição de sedimentos finos. A abertura de canais e a se cagem de manguesais por redes de drenagem artificiais devem por fim serem considerados, jā que modificam, ao menos localmente, os processos de remoção e deposição de sedimentos. 


\section{Transporte litorâneo}

Conforme a proposta de SILVESTER (1968, 1974) procuramos usar a morfologia costeira e distribuição das faixas sedimentares pára. avaliar o sentido do transporte litorâneo.

No chamado litoral sul do Estado de são Paulo, se conside rarmos os trechos Ilha do Cardoso/Morro da Juréia, Ponta Parana puá-Guaçu/Ponta de Itaipu e Ponta de Santo Amaro/Ponta da Una, po demos verificar, pelas cartas topogräficas e geológicas (sUGUIo \& - MARTIN, 1978al que a morfologia da linha de costa apresenta certa concavidade nas partes sul dos referidos trechos. A isto pode-se acrescentar que as planícies costeiras, nesses mesmos trechos,cres cem mais de sul para norte, por adição de sedimentos holocênicos, ficando os afloramentos da Formação Cananëia cada vez mais para o interior, nesse mesmo sentido. Essa situação indicaria um transpor te litorâneo resultante para norte.

No que se refere ao litoral norte, a pequena expressão de planícies costeiras não permite concluir por um sentido predomi nante de transporte. Ambas as assertivas concordam com as observa ções de SILVESTER (1968) para os trechos de costa considerado.

Ademais, procedemos a análise de imagem LANDSAT-1, que mos trou um padrão de dispersão de sedimentos na plataforma, indicati vo de corrente costeira sudoeste-nordeste, defletida à altura de Santos, por inflexão da linha de costa (PONÇANO, 1976) (FIGURA 45) de modo concordante e complementar às conclusões tiradas da morfo logia costeira continental.

D. Caracteristicas dos sedimentos de superficie de fundo

1. Composição granulomētrica

A distribuição dos diâmetros mëdios (FIGURA 46) mostra,pa ra todo o estuärio, predominio de siltes. Areas restritas de argi las ocorrem nos largos e no Canal da Bertioga, enquanto que areias ocorrem associadas a rios que drenam sedimentos arenosos da baixa da, ou a pontões cristalinos.

A baịa deixa-se dividir em dois setores, oeste e leste, o primeiro arenoso e o segundo siltoso. A ligação do setor oeste com o Canal de são Vicente, sugere continuidade das areias da baía para o interior do estuário. Já o setor leste apresenta pre 


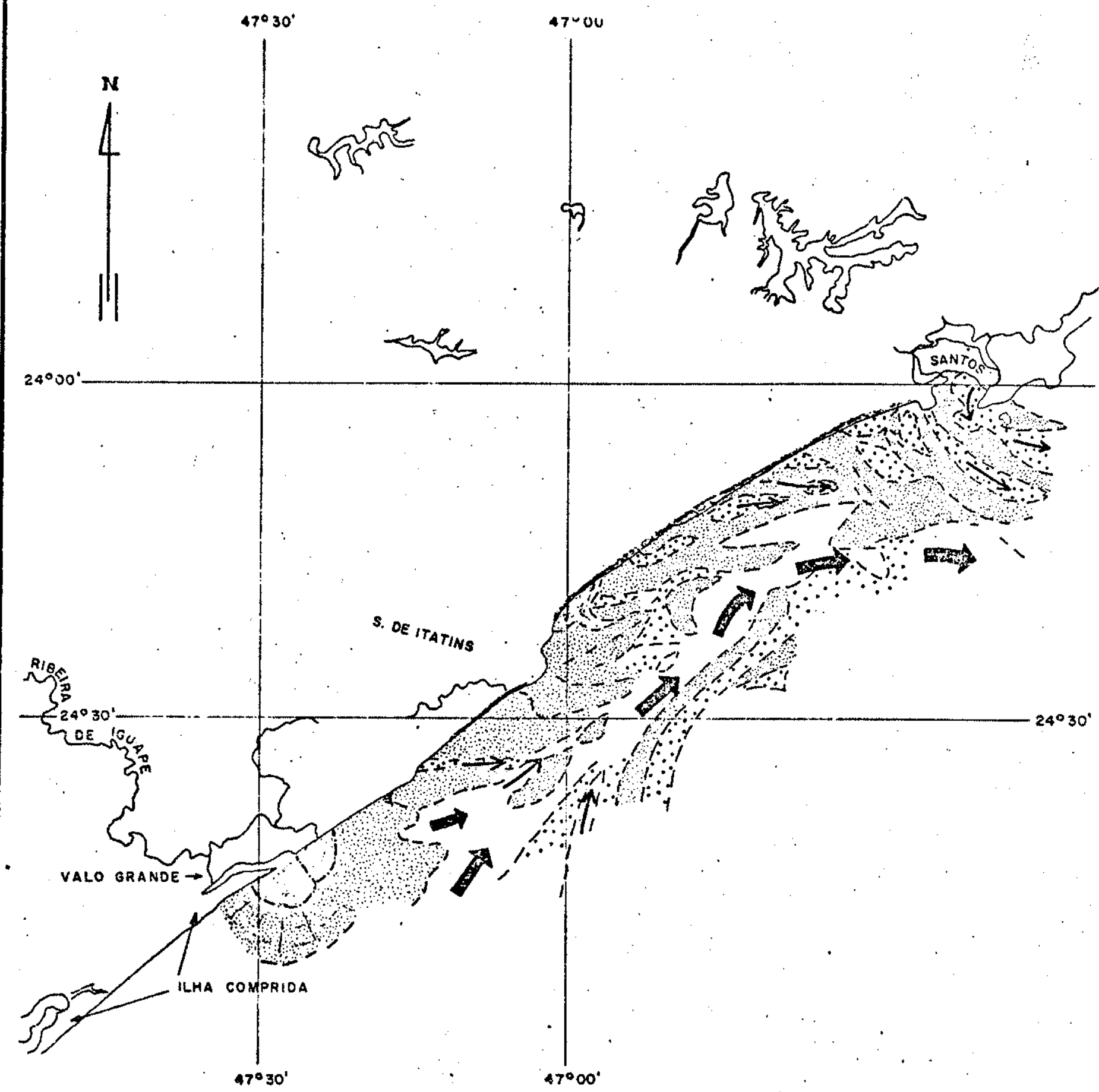

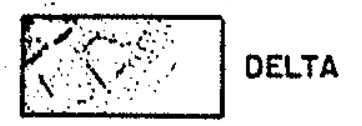

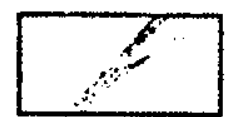

ZONA DE OEPOSIÇĀO DE SEDIMENTOS

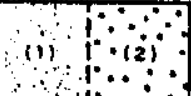

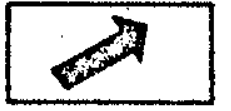

DIPECCÃO PRINCIPAL DE CORRENTE

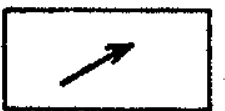

DIREÇÃO SECUNDÁRIA DE CORRENTE

FIGURA 45 - Características gerais da sedimentação e correntes na costa paulista (PONÇANO, 1976). 


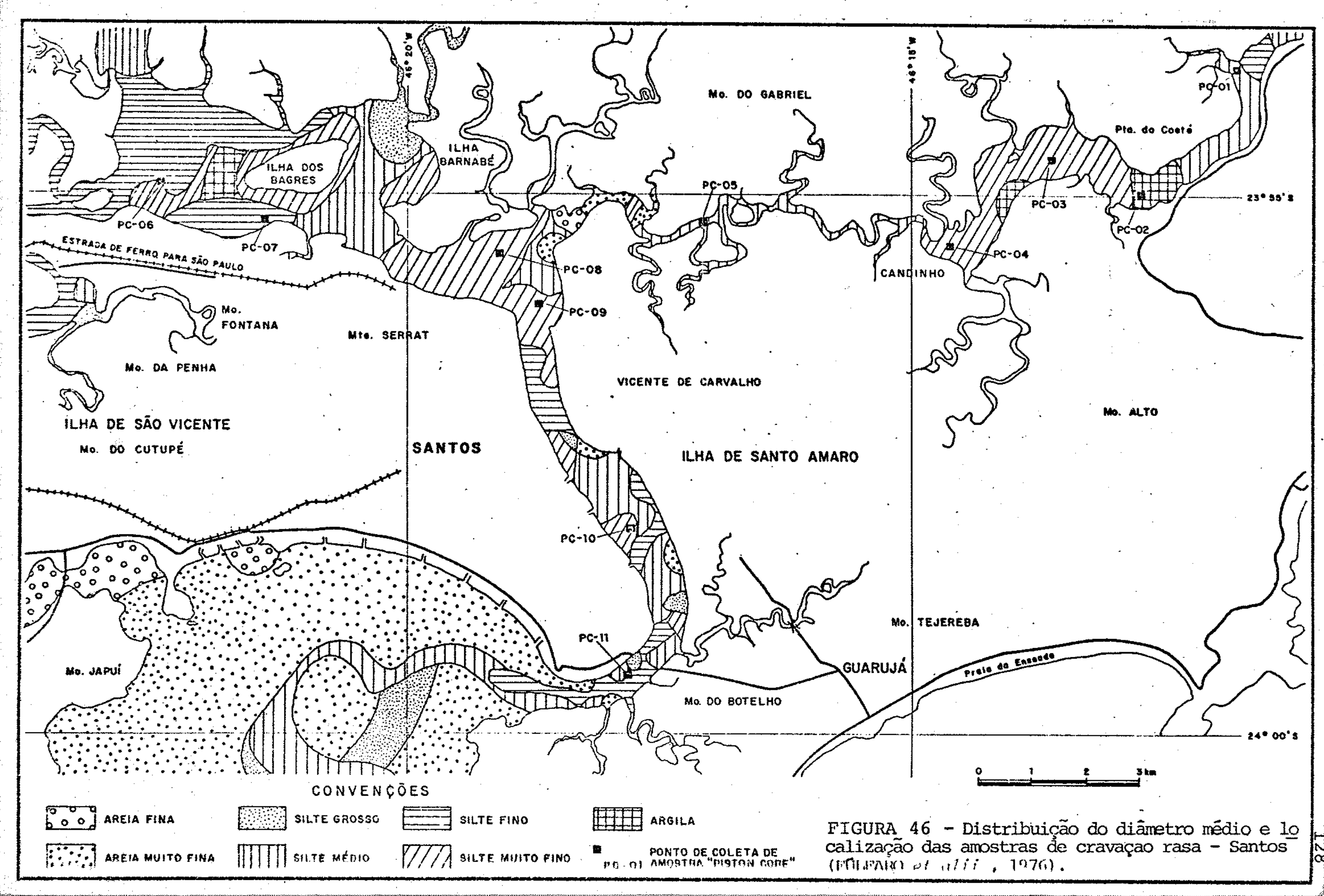


domínio de siltes, em continuidade com os sedimentos do canal do Porto.

Sedimentos bem selecionados coincidem com as äreas de sedi mentos arenosos (FIGURA 47). No interior do estuärio essa situação parece refletir um selecionamento prévio, jā que se trata de areias retrabalhadas de depósitos marinhos prévios. Na baía, po rém, a situação é diversa, pois, face à predominância de siltes no interior do estuário, não se pode atribuir origem estuarina às areias do setor oeste.

Devem elas portanto ter origem da plataforma continental, através do transporte litorâneo que indicamos no item precedente.

Isso posto, hă que considerar que o bom selecionamento dessas areias contraria a expectativa quanto à imaturidade textural dos sedimentos da plataforma, o que leva a formular duas hipóteses para o caso. A primeira è de que os sedimentos transportados ao longo da costa afetam material previamente selecionado (. das praias, por exemplo). A segunda deve levar em conta um processo de seleção local.

A primeira hipötese não é totalmente inviável quando se con sidera a enorme extensão de praias arenosas a sul da Baía de san tos. Entretanto, conforme mostramos anteriormente atravês das ima gens de satëlite, hä tambēm material em suspensão sofrendo trans porte no mesmo rumo, para norte, de tal sorte que a baía, nessas imagens, mostra também os dois setores oeste e leste, notados atra vés dos sedimentos de superfície de fundo, embora o primeiro apre sente mais material em suspensão que o segundo.

Dessa forma, admitindo a validade dos critērios de análise de imagens de satélite empregados, a situação de material de fun do e em suspensão é especular: os fundos arenosos da baỉa corres pondem a lâmina d'ägua com maiores teores de material em suspensão, e vice-versa.

Assim, cremos poder deduzir desta exposição, que, embora não totalmente excluída a primeira hipōtese, terämais peso a segunda, permitindo então sugerir que os sedimentos finos permaneçam em suspensão no setor oeste da baía por atuação de correntes que re volvem os fundos dessa área: o material fino poderia então passar ao setor leste, talvez mesmo entrando parcialmente no estuário. 


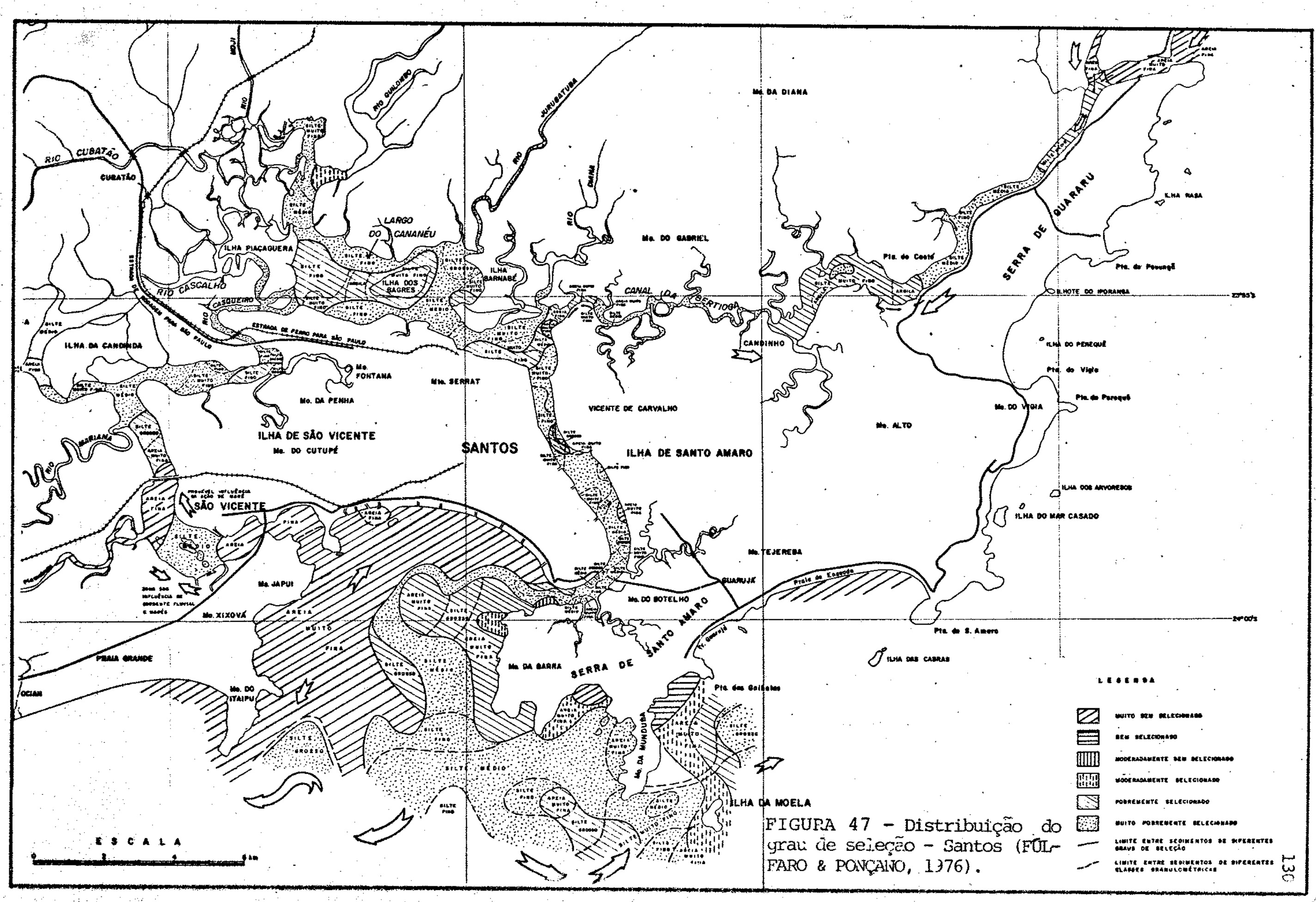


Haviamos, em trabalho anterior, aventado esta possibilidade (FUL FARO \& PONÇANO, 1976).

A distribuição da assimetria (FIGURA 48) mostra, para ' a baía, uma área de predominio de valores negativos, e outra de po sitivos, aproximadamente concordantes com os dois setores da baía acima mencionados. No estuário, valores negativos predominam do largo do Canëu até quase a desembocadura do Canal do porto, e em grande parte do Canal de Bertioga. FÚfFARO \& PONÇANo (1976) atri buern às áreas de assimetria negativa remoção de finos por corren tes de fundo, o que levaria à formação de sedimentos com distri buições granulométricas com caudas mais pronunciadas em suas frá ções mais grossas. Essa assertiva ē empirrica, mas apresenta con cordância com as observações feitas a partir dos dois primeiros momentos.

o padrão de distribuição da curtose (FIGURA 49) é extrema mente complexo, o que atribuimos (FULFARO \& PONÇANO, 1976) a sua sensibilidade a pequenas flutuações no ambiente deposicional, re fletidas nas aistribuições granulónetricas. Esta proposição está em concoraância com a observação de FOLK \& WARD (1957) de que a curtose é uma espécie de resultante das relações entre os outros parâmetros granulométricos (FIGURA 5).

Näo nos parece possível deduzir empiricamente o significado dinâmico da curtose, no caso de santos. Entretanto, podemós notar um certo predomínio de valores muito platicürticos a partir do Largo do Canéu, ao longo do Canal do Porto e, barra afora, no se tor leste da baía (FIGURA 49). Esta situaçäo é sugestiva de maior heterogeneidade, embora não necessariamente de plurimodalidade, na composição dos sedimentos dessa ărea, indicativa de possível mis tura de populações diversas. No caso, estas populações poderiam ser basicamente duas: a dos finos de origem continental, e a dos finos provenientes do setor oeste da baía.

Como se pode perceber, procuramos, neste trabalho, avänçar além da caracterização faciológica para uma interpretação dinâmica dos parâmetros estatísticos granulométricos, assunto que vem sendo objeto da atenção de numerosos autores, e sobre que hã sē rias divergências.A. combinação de observações regionais e locais permitiram-nos efetuar algumas interpretações que, não obstante 


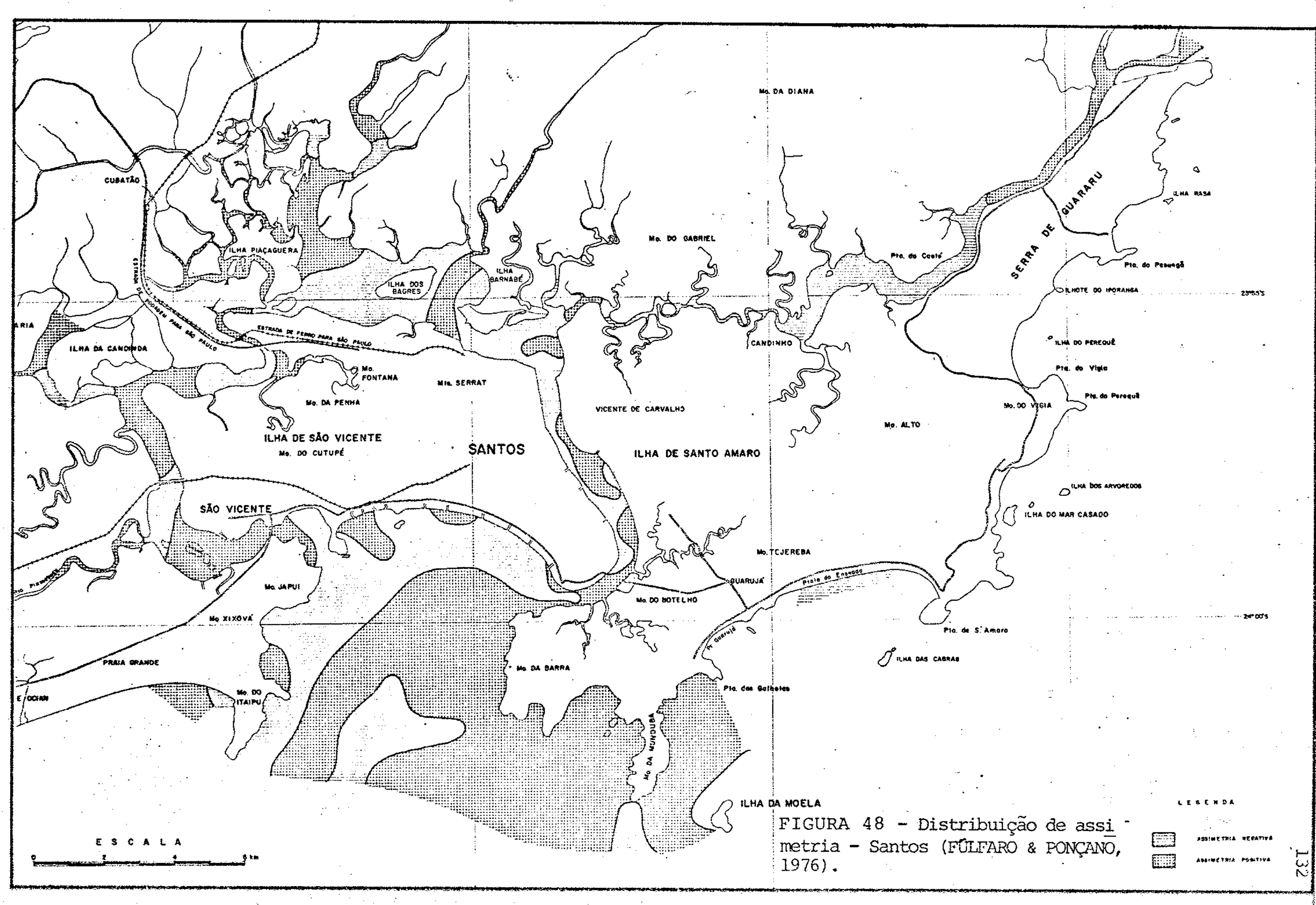




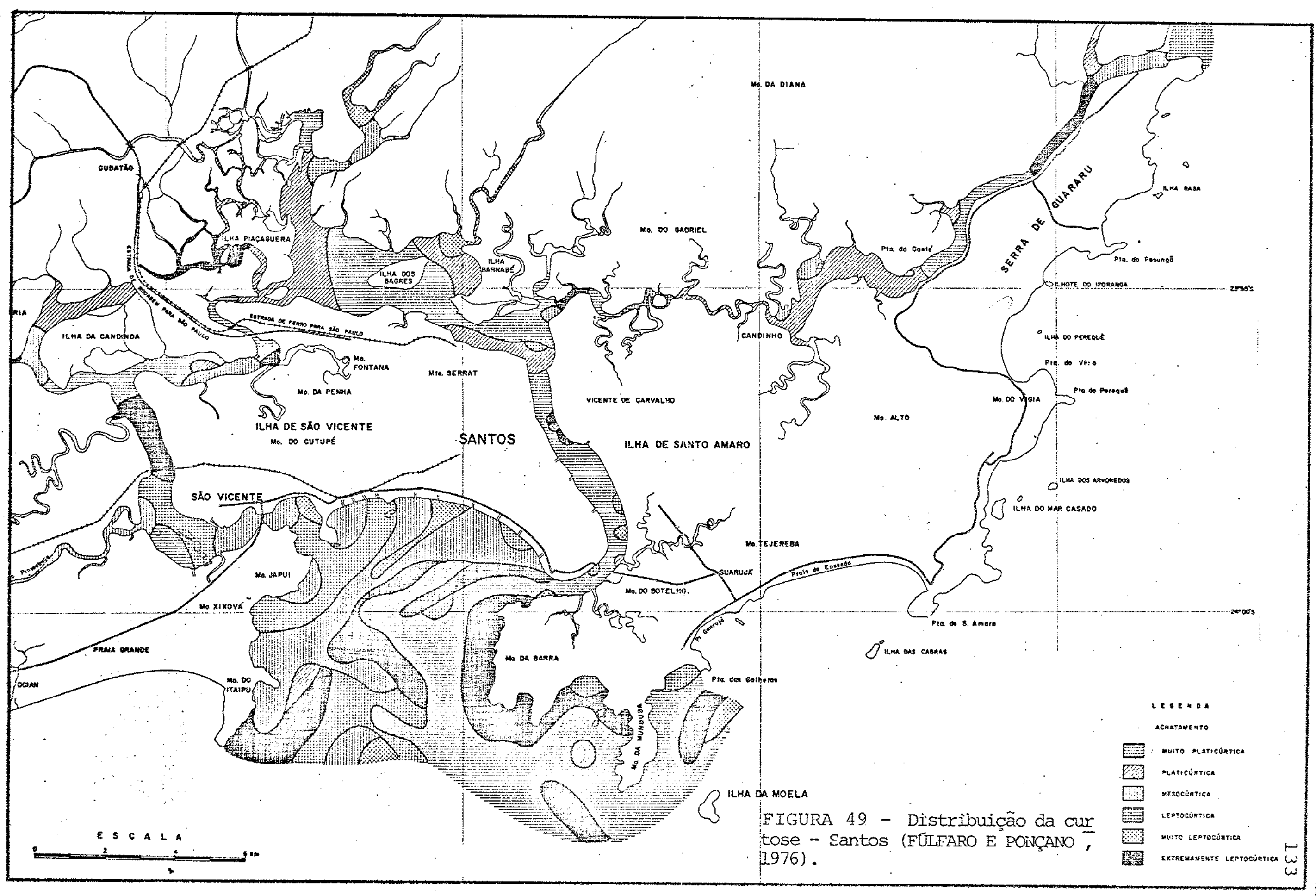


seu interesse, têm que ser encaradas como preliminares, empiricas, e välidas para o caso em foco.

2. Composição mineralógica

Cerca de metade das amostras de superficie de fundo, distri buidas em toda a ärea de interesse, foram examinadas quanto a seu conteüdo mineralógico na fraçäo leve, nos intervalos corresponden tes a areia fina $(0,250-0,125 \mathrm{~mm})$ e areia muito fina $(0,125$ $0,062 \mathrm{~mm}$ ). FULFARO \& PONÇANO (1976) consideram, que dos resulta dos obtidos a partir da distribuição de feldspatos, micas e fragmentos vegetais, os mais interessantes referem-se aos feldspatos, que a seguir serão examinados.

Considerando a presença de feldspatos nos dois intervalos granulométricos estudados, pode-se perceber que se distribuem de modo francamente descontínuo pelo estuário e baía (FIGURA 50), em quatro áreas.

A mais expressiva situa-se na baía, especialmente no setor oeste: a segunda abrange a comunicação marinha do Canal de Bertio ga. Outras ocorrências situam-se em gamboas a montante do Largo do Canēu, enquanto que uma ünica aparece a montante do canal do Porto, próximo à sua junção com o'Canal de Bertioga.

Assim, pode-se reconhecer no estuạrio e baía, excetuando o Canal de Bertioga, duas äreas distintas de ocorrência de feldspa tos; que levam a supor duas āreas-fontes tambēm distintas. Uma es taria relacionada à rede fluvial que da serra desagua no estuärio, e outra situa-se na plataforma continental.

Haviamos considerado que o limite de ocorrência dos feldspa tos de origem fluvial era coincidente com a faixa de distribuição dos manguesais, o que mostraria a importância dessa feição na re tenção de descarga sölida fluvial (FULFARo \& PONÇANo, 1976). Acreditamos que essa coincidência existe; entretanto, o número de amostras em que isso se verifica (três) parece-nos demasiadamente pequeno para comprovar essa assertiva, pelo que, preferimos to má-la como hipótese a ser provada.

A ocorrência situada a montante do Canal do porto foi atri buída por FULFARO \& PONÇANO (1976) à proximidade de pontão cristalino, que de fato lá ocorre, Entretanto, chama-nos a atenção que situações anālogas, nas proximidades do Morro da Barra, Ponta 


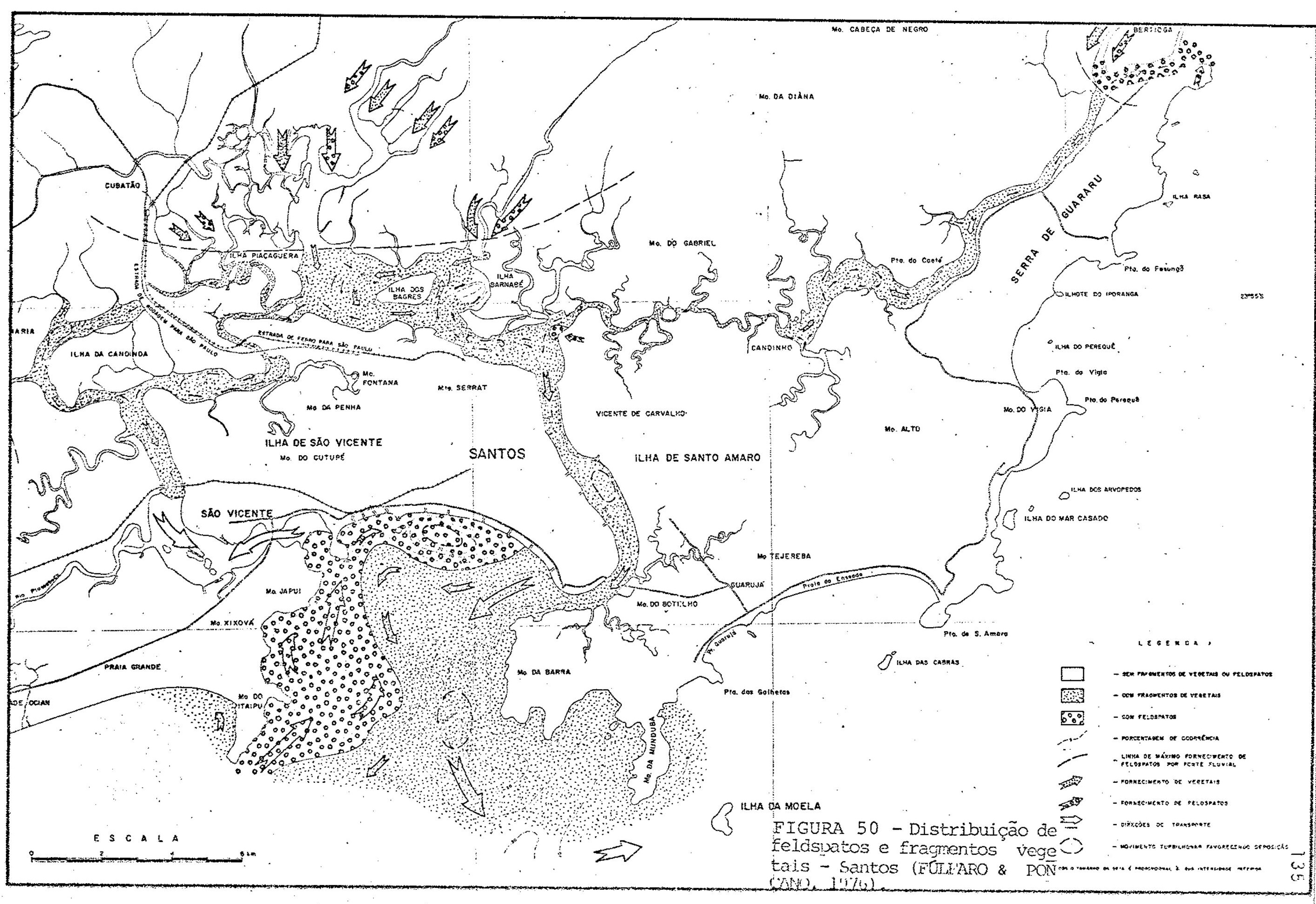


Munduba e Ponta Itaipu, não mostrem resultados comparäveis.

As ocorrências de feldspato no setor oeste da baía, seriam indicativas de que os sedimentos de fundo dessa ārea seriam prove nientes de plataforma continental, trazidos por transporte litorâa neo (FULFARO \& PONÇANO, 1976). Conforme tivemos a ocasião de mos trar na apresentação dos dados da morfologia costeira, sensoriamento e faciologia, parece-nos muito plausivel admitir esse trans porte, de sul para norte, com inflexão para dentro da baía contor nando a Ponta de Itaipu. Entretanto, essa ocoxrência poderia tam bém ser explicada se admitirmos que os sedimentos arenosos do setor oeste da baía sejam reliquiares, conforme aventaram BITTEN COURT et alii (1979) para a Baia de Todos os Santos. Analogamente pode ser interpretada a ocorrência de feldspatos na 1igação oceâ-nica do Canal de Bertioga.

Não temos elementos para chegar a uma conclusão sobre esse assunto. Entretanto, procedemos a amostragem ( em 123 estações) pa ra verificar a hipötese da entrada de areias da plataforma para - setor oeste da baía (PONÇAÑo \& FúLEARO, 1975). Os resuitados ob tidos, dos quais apresentamos a distribuj ção dos diâmetros médios (FIGURA 5I) são sugestivos de que esse aporte efetivamente ocorra da forma mencionada.

3. Variações temporais das fácies sedimentares de superfí cie de fundo

Como se pôde perceber ao longo da exposição dos diferentes casos deste trabalho, a principal contribuição dos estudos de se dimentação em corpos d'ägua costeiros a projetos de engenharia. consiste no fornecimento de dados básicos referentes ao meio físico, do ponto de vista geológico. Em decorrência, surgiu a preo cupação de se ter uma estimativa da validade dos padrões faciológicos determinados, o que se refletiu jä no caso da Baía de Todos os Santos, em que julgamos adequado realizax nova amostragen de āreas jä abordadas pela literatura. No caso dẻ Santos, examinamos essa questão em duas āreas distintas, quais sejam, as adjacências da Ponta de Itaipu e a Bacia de santos.

Nas adjacências da ponta de Itaipu, procedemos a cinco eta pas de amostragem, segundo a malha da FIGURA 52, em dezembro de 1984, janeiro, março, agosto e outubro de 1975. Os resultados ob 


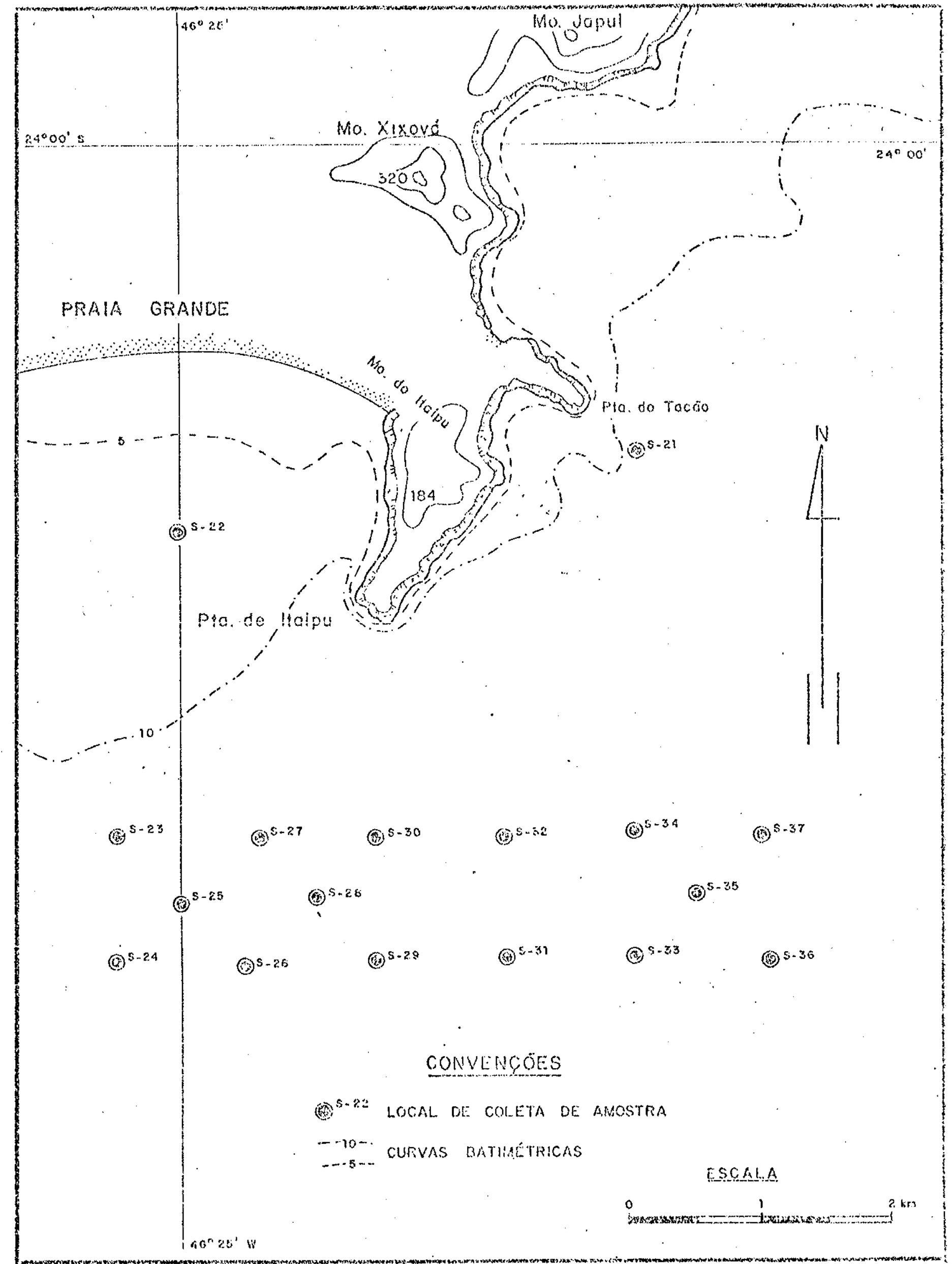

TIGURA 52 - Localização das estações de coleta de amostras de controle nas adjacên cias da Ponta de Itaipu. 
tidos foram comparados através dos diâmetros mëdios

(FIGURA

53 ). No conjunto notam-se pequenas altexações, geralmente osci. laçöes para intervalos granulomëtricos próximos, sugerindo que o padrão em faixás de granulometrias diferentes (FIGURA 5I) se man térn.

No caso da Baía de Santos, realizamos comparação entre os resultados da campanha de 1973 (FIGURA 46) com os de outra campa nha efetuada em 1980. Esta ültima consistiu em amostragem de 98 estações, situadas nos mesmos locais das da primeira campanha. To mando como comparação as variações de diâmetros médios, temos os resultados das FIGURAS 54 e 55. Elas mostram mesmos diânetros mé dios em 55 estações; das 43 restantes, houve aumento de diämetro mëđio em 22 casos e diminuição em 21 .

A fim de comparar as variações observadas em planta, proce demos inicialmente à atribuição de ảreas de infiluência às esta ções de amostragem, representando a segujr, com mesmos critërios, as situações de 1973 e 1980 (FIGURAs 56 e 57), dando ênfase à sepa ração de areids e siltes, caracteristicos dos selores oesle e les te da baía, respectivamente. A variação deste limite pode ser vi sualizada na FIGURA 58 .

Podemos concluir que o padräo geral dos dois setores da baía sẹ mantêm. pode-se notar, adicionalmente, que as mudanças de limites entre áreas siltosas e arenosas podem ser devidas tanto à remoção de finos, como a movimentação de areias; esta questão parece-nos passivel de resolução somente através de investigação da coluna rasa do fundo da baia, buscando estruturas sedimentares, ou mesmo por meio de análise de espalhamento de radioisótopos.

E. Agregação de partículas

Havíamos notado (FULFARO \& PONÇANO, 1976) que os sedimentos de superficie de fundo do estuärio santista compunham-se essencialmente de siltes; depósitos francamente argilosos eram muito xaros, ocorrendo, no estuäxio, somente no Largo do Canēu ( FIGURA 46 ). Concluímos, em decorxência, que a floculação teria um papel subordinado na sedimentação regional, e que as principais acumula cões de argilas nos fundos do estuário poderiam ser mais apropria damente atribuidas a regiões de energia nula de transporte, cox respondentes ao encontro de frentes opostas de propagação de maré, 


\begin{tabular}{|c|c|c|c|c|c|c|c|c|}
\hline DATA DE COLETA & AMOSTRA & $\begin{array}{c}\text { DIANEIRO } \\
\text { MEDIO }\end{array}$ & DATA DE COLETA & AMOSTRA & $\begin{array}{c}\text { DIAMETRO } \\
\text { MEDIO }\end{array}$ & DATA DE COIETA & FNOSTRA & $\begin{array}{c}\text { DIÂMETRO } \\
\text { MEDIO }\end{array}$ \\
\hline $11-12 / 21 / 1974$ & $S-21$ & areia m.fina & $11-12 / 11 / 1974$ & $5-27$ & silte méaio & $11-12 / 11 / 1974$ & $s-33$ & areia m.fina \\
\hline $15-20 / 01 / 1975$ & $S-21 A$ & areia m.fina & $15-20 / 11 / 1975$ & $S-27 A$ & areia m.fina & $15-20 / 01 / 1975$ & $S-33 A$ & silte mëđio \\
\hline $15 / 05 / 1975$ & $S-21 B$ & areia m.fina & $15 / 05 / 1975$ & $S-27 B$ & silte m.fino & $1.5 / 05 / 1975$ & $S-33 B$ & silte médio \\
\hline $\begin{array}{r}13-18 / 08 / 1975 \\
20 / 10 / 1975\end{array}$ & $S-21 C$ & areia m.fina & $\begin{array}{r}13-18 / 08 / 1975 \\
20 / 10 / 1975\end{array}$ & $S-27 C$ & areia m.fina & $13-18 / 08 / 1975$ & $s-33 c$ & silte mëdio \\
\hline & & areia m.tina & $20 / 10 / 1975$ & $S-27 D$ & areia m.fina & $20 / 10 / 1975$ & $S-33 D$ & silte médio \\
\hline $11-12 / 11 / 1974$ & $S-22$ & areia m.fina & $11-12 " 11 / 1974$ & $S-29$ & areia m.fina & $11-12 / 11 / 1974$ & $s-34$ & areia m.fina \\
\hline $15-20 / 01 / 1975$ & $S-22 A$ & areia m.fina & $15-20 / 01 / 1975$ & $S-29 A$ & areia m.fina & $15-20 / 01 / 1975$ & $S-34 A$ & areia m.fina \\
\hline $15 / 05 / 1975$ & $S-22 B$ & silte grosso & $15 / 05 / 1975$ & $S-29 B$ & silte médio & $15 / 05 / 1975$ & $S-34 B$ & areia m.fina \\
\hline .13-18/08/1975 & $S-22 C$ & areia m.fina & $13-18 / 08 / 1975$ & $s-29 C$ & siite méaio & $13-18 / 08 / 1975$ & $S-34 C$ & areja m.fina \\
\hline $20 / 10 / 1975$ & $S-22 D$ & areia m.fina & $20 / 10 / 1975$ & $S-29 D$ & silte fino & $20 / 10 / 1975$ & $S-34 D$ & areia m.fina \\
\hline $11-12 / 11 / 1974$ & $\mathrm{~s}-23$ & silte m.fino & $11-12 / 11 / 1974$ & $s-30$ & areia m.fina & $11-12 / 11 / 1974$ & $s-35$ & areia m.fina \\
\hline $15-20 / 01 / 1975$ & $S-23 A$ & silte fino & $15-20 / 01 / 1975$ & $\mathrm{~S}-30 \mathrm{~A}$ & areia m.fina & $15-20 / 01 / 1975$ & $S-35 A$ & silte fino \\
\hline $15 / 05 / 1975$ & $S-23 B$ & silte fino & $15 / 05 / 1975$ & $S-30 B$ & areia m.fina & $15 / 05 / 1975$ & $S-35 B$ & silte fino \\
\hline $13-18 / 08 / 1975$ & $S-23 C$ & & $13-18 / 08 / 1975$ & $S-30 C$ & silte fino & $13-18 / 08 / 1975$ & $S-35 c$ & areia m.fina \\
\hline $20 / 10 / 1975$ & $S-23 D$ & silte médio & $20 / 10 / 1975$ & $S-30 D$ & areia m.fina & $20 / 10 / 1975$ & $S-35 D$ & areia m.fina \\
\hline $11-12 / 11 / 1974$ & $S-24$ & silte mëdio & $11-12 / 11 / 1974$ & $s-31$ & silte mëdio & $11-12 / 11 / 1974$ & $S-36$ & silte grosso \\
\hline $15-20 / 01 / 1975$ & $S-24 A$ & silte médio & $15-20 / 01 / 1975$ & $S-3 I A$ & silte grosso & $15-20 / 01 / 1975$ & $S-36 A$ & areia m. fina \\
\hline $15 / 05 / 1975$ & $S-24 B$ & areia m.fina & $15 / 05 / 1975$ & $S-31 B$ & silte médio & $15 / 05 / 1975$ & $S-36 B$ & silte grosso \\
\hline $13-18 / 08 / 1975$ & $S-24 C$ & areia m.fina & $13-18 / 08 / 1975$ & $S-31 C$ & silte fino & $13-18 / 08 / 1975$ & $S-36 C$ & areia m.fina \\
\hline $20 / 10 / 1975$ & $S-24 D$ & areia m.fina & $20 / 10 / 1975$ & $S-310$ & silte fino & $20 / 10 / 1975$ & $S-36 D$ & areia m.fina \\
\hline $11-12 / 11 / 1974$ & $S-25$ & silte fino & $11-12 / 11 / 1974$ & $S-32$ & silte mëaio & $11-12 / 11 / 1974$ & $S-37$ & silte médio \\
\hline $15-20 / 01 / 1975$ & $S-25 A$ & areia m.fina & $15-20 / 01 / 1975$ & $S-32 A$ & areia m.fina & $15-20 / 01 / 1975$ & $S-37 A$ & silte grosso \\
\hline $15 / 05 / 1975$ & $S-25 B$ & areia m. fina. & $15 / 05 / 1975$ & $S-32 B$ & areia m.fina & $15 / 05 / 1975$ & $S-37 B$ & silte grosso \\
\hline $13-18 / 08 / 1975$ & $S-25 C$ & areia m.fina & $13-18 / 08 / 1975$ & $s-32 C$ & silte médio & $13-18 / 08 / 1975$ & $S-37 C$ & areia m.fina \\
\hline $20 / 10 / 1975$ & $S-25 D$ & areia m.fina & $20 / 10 / 1975$ & $S-32 D$ & areia m.fina & $20 / 10 / 1975$ & $S-37 D$ & areia m.fina \\
\hline $11-12 / 11 / 1974$ & $S-26$ & areia m. fina & & & & & & \\
\hline $15-20 / 01 / 1975$ & $S-26 A$ & silte médio & & & & & & \\
\hline $15 / 05 / 1975$ & $S-26 B$ & silte médio & & & & & & \\
\hline $13-18 / 08 / 1975$ & $S-26 C$ & silte méäio & & & & . & & \\
\hline $20 / 10 / 1975$ & $S-26 D$ & areia m.fina & & & & & & \\
\hline
\end{tabular}

FIGURA 53 - Tabela comparativa de variações de diâmetro mëdio nas adjacências da Ponta de Itaipu . 
NO DA AMOSTRA.

1

2

3

4

5

6

7

8

9

10

11

12

13

14

15

16

17

18

19

20

21

22

23

24

25

26

27

28

. 29

31

32

33

34

35

36

37

38

39

40

41

42

43

44

45

46

47

48

49

50

51
DIAMETRO MEDIO

(1980)

\begin{abstract}
Areia fina
Areia fina

Areia muito fina

Areia muito fina

Areia muito fina

Areia muito fina

Areia muito fina

Areia muito fina

Areia muito fina

Areia muito Eina

Areia muito fina

Areia muito fina

Areia mujto fina

Areia muito fina

Areia muito fina
\end{abstract}

Silte fino

Areia muito fina

Silte muito fino

Silte muito fino

Areia muito fina

Silte grosso

Areia muito fina

Areia muito fina

Areia muito fina

Areia muito fina

Areia mujto fina

Areia muito fina

Areia muito fina

Areia muito fina

Areia muito fina

Silte Grosso

Silte fino

Areia muito fina

Areia muito fina

Areia muito fina

silte médio

silte médio

Silte grosso

Silte grosso

Areia muito fina

Areia muito fina

Areia muito fina

silte mëdio

Silte grosso

Areia muito fina

Areia muito fina

Areia muito fina

Areia muito fina

Areia muito fina

Areia muito fina

Silte fino
DIAMETRO MEDIO

(1973)

Areia fina

Areia fina

Areia fina

Areia muito fina

Areia muito fina

Areia muito fina

Areia muito fina

Areia muito fina

Areia muito fina

Areia muito fina

Areia muito fina

Areia muito fina

Areia muito fina

Areia muito fina

Areja muito fina

Areia muito fina

Silte mëdio

Areia muito fina

Silte fino

Areia muito fina

Areia muito fina

Silte médio

Areia muito fina

Areia muito fina

Areja muito fina

Silte médio

Areia muito fina

silte médio

Areia muito fina

Areia muito fina

Areia muito fina

silte médio

Areia muito fina

Areia mujto fina

Areia muito fina

Silte grosso

silte médio

Silte médio

Areia muito fina

Areia muito fina

Areja muito fina

Areia muito fina

Areia muito fina

Silte grosso

silte mëdio

Areia muito fina

Areia mujto fina

Areia muito fina

Silte grosso

Areia muito fina

silte fino

FIGURA 54 - Tabela comparativa de diâmetros médios na Baía de santos (1) 
NQ DA AMOSTRA

52
53
54
55
56
57
58
59
60
61
62
63
64
65
66
67
68
69
70
71
72
73
74
75
76
77
78
79
80
81
82
83
84
85
86
87
88
89
90
91
92
93
94
95
96
97
98
99
100
101
102
55

DTAMETRO MEDIO

(1980)

silte fino

silte médio

Silte médio

Areia muito fina

Areia muito fina

Silte muito fino

Areia muito fina

Areia muito fina

Areia muito fina

Areia muito fina

Areia muito fina

Areia muito fina

silte médio

silte médio

silte médio

silte médio

silte médio

silte médio

Areia muito fina

Areia muito fina

Silte grosso

Areia muito fina

Silte grosso

Areia muito fina

silte grosso

Silte fino

Silte grosso

Areia muito fina

Silte médio

silte mëaio

silte grosso

silte mëdio

silte fino

silte médio

Axeia muito fina

Areia muito fina

não hā amostra com

Areia muito fina

Areia muito fina

Areia muito fina

Silte grosso

Silte mëdio

silte mëdio

silte médio

Silte mëdio

silte médio

Silte grosso

Silte grosso

Silte médio

silte fino

Silte muito fino
DIAMETRO MEDIO

(1973)

Areia muito fina

silte muito fino

Areia muito fina

Areia muito fina

Areia muito fina

silte mëdio

Areia muito fina

Areia muito fina

silte grosso.

Silte grosso

Areia muito fina

silte médio

Silte médio

silte médio

silte médio

sil.te mëdio

silte médio

silte médio

Areia muito fina

Areia muito fina

Silte fino

silte mëdio

Areia muito fina

Silte mẽdio

Axeia muito fina

Silte médio

Areia muito fina

silte médio

silte médio

silte médio

Areia muito fina

silte mëdio

silte muito fino

silte médio

Areia muito fina

Areia muito fina

esta numeração

silte médio

Areia muito Eina

Areia muito fina

silte fino

silte grosso

Areia muito fina

não há amostra equiva

lente

Idem

Idem

silte médio

silte médio

Silte grosso

silte muito fino

silte fino

FIGURA 55 - Tabela comparativa de diâmetros mëdios na Baĩa de Santos 


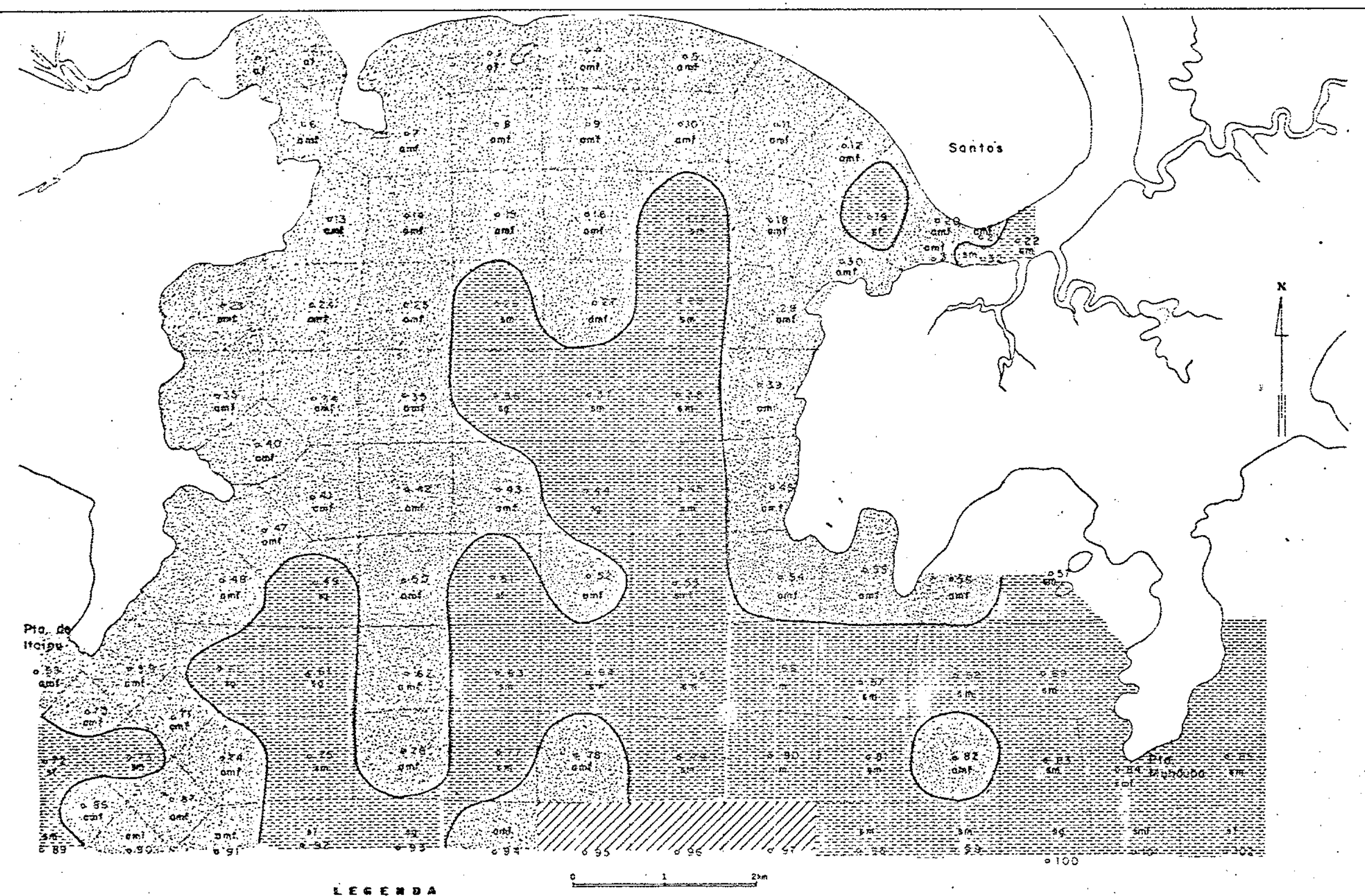

SILES 2n! x sille muito ting

31 a silte ting

TH AREIAS omt = areio muito fing

sm silse mécio

a) = oreis tine

FIGURA 56 - Distribuição do diâmetro médio

em

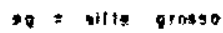

DDA Libea näo amostrada 


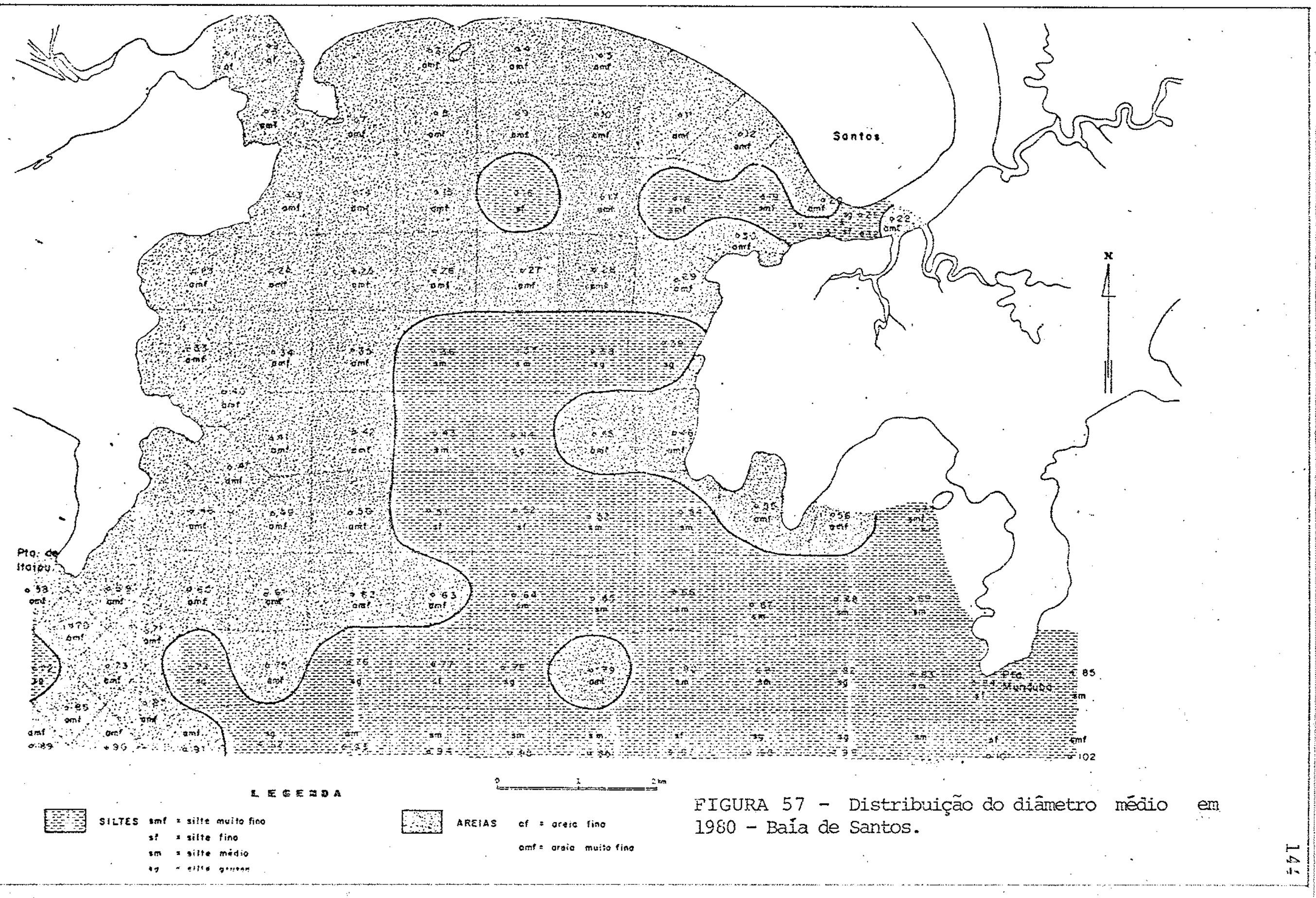




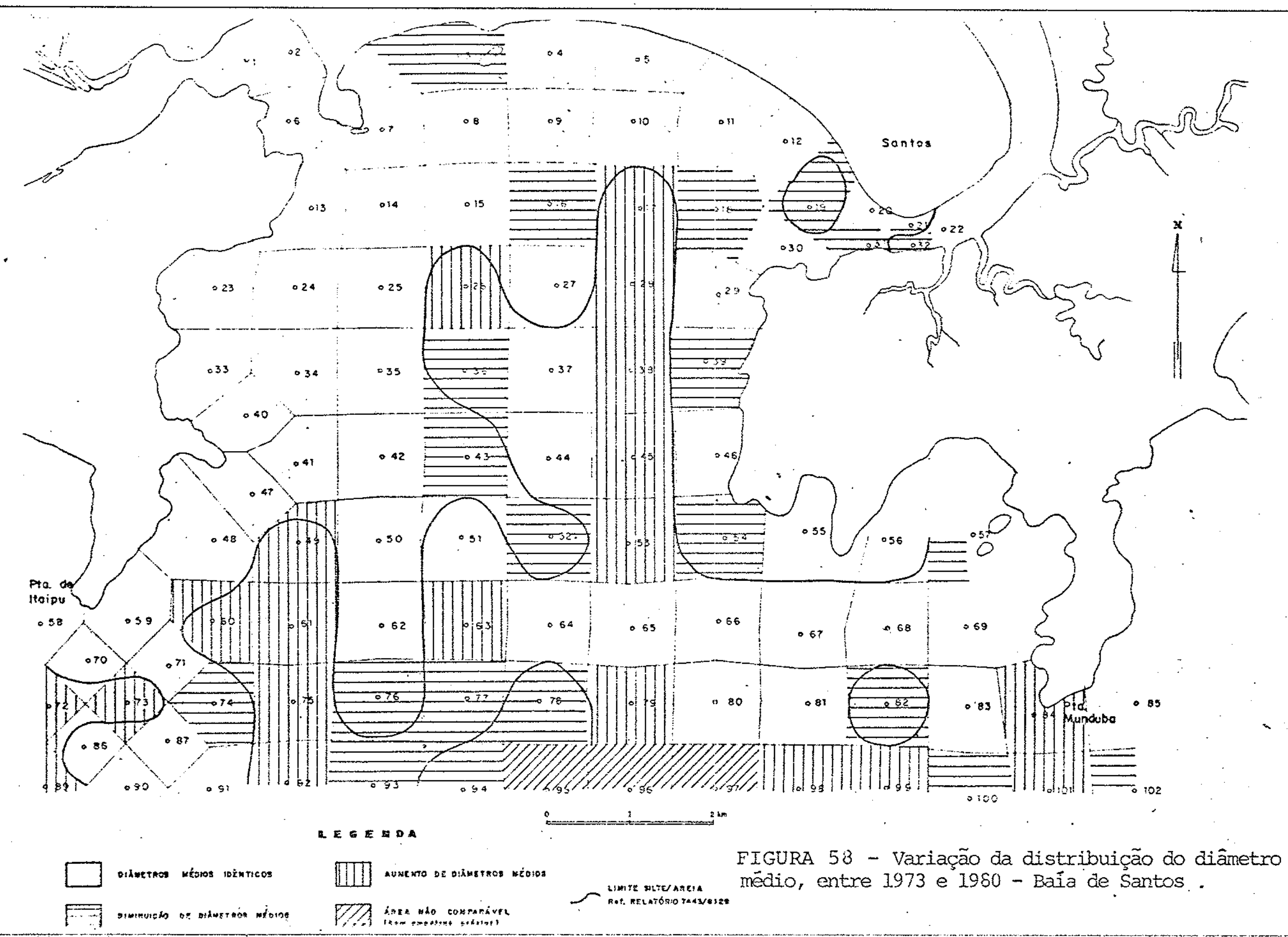


provenientes dos canais do Porto e de São Vicente.

procedemos então à coleta de testemunhos rasos, por cravação de amostrador do tipo piston corer, cuja distribuição é indi. cada na FIGURA 46. Os resultados obtidos (FIGURAS 59 a 62) mostram fre quentes descontinuidades na sedimentação, sendo comuns intercalações de camadas ou lâminas arenosas. Pareceu-nos à época, e ainda concordamos em parte: com essa conclusão, que essas variações de energía do meio, indicadas pelas variações texturais ao longo das colunas sedimentares, eram incompatíveis com a deposição em bancos argillosos exclusivamente por floculação. Acreditávamos então que essa situação poderia ser explicada pela grande mobilidade das argilas; resultiante da diminuição da viscosidade da ägua devido a temperaturas mais elevadas (relacionadas ao clima tropical vigente), o que tenderia a manter os colóides em suspensão (TRICART , 1972).

Segundo POSTMA (1967), alguns estudos têm mostrado que: a floculação é diferencial para os diversos argilo-minerais, devido às suass afferentes estruturas. Segundo esse autor, são as con dições físico-quimjcas; e não o tamanho das partículas envolvidas, - fator fundamental na floculação. Assim, experimentos mostraram que caolinitas e illitias floculam completamente sob baixos teores de cloretos, enquanto que as montmorillonitas vão floculando pro gressivamente mais, à medida que aumentam os teores de cloretos. Essa diferença é atribuida a maior estabilidade da dupla capa ca tiônica das montmorillonitas.

POSTMA (1967) considera ainda que em correntezas muito räpi das os argilo-minerais são transportados de modo indiferenciado ; a menores velocidades as illitas e caolinitas poderiam se depositar, enquanto que as montmorillonitas continuariam a ser transpor tadas.

pode-se inferir dessas considerações que nas ãguas salobras e sujeitas a diminuição de velocidades de corrente dos estuários, haveria tendência à maior deposição de illitás e caolinitas, en quanto que montmorillonitas ocorreriam mais frequlentemente nos baixos estuärios.

KRANK (1975 e 1981) critica várias dessas conclusões, apon tando que foram essencialmente obtidas por experimentos de labo- 

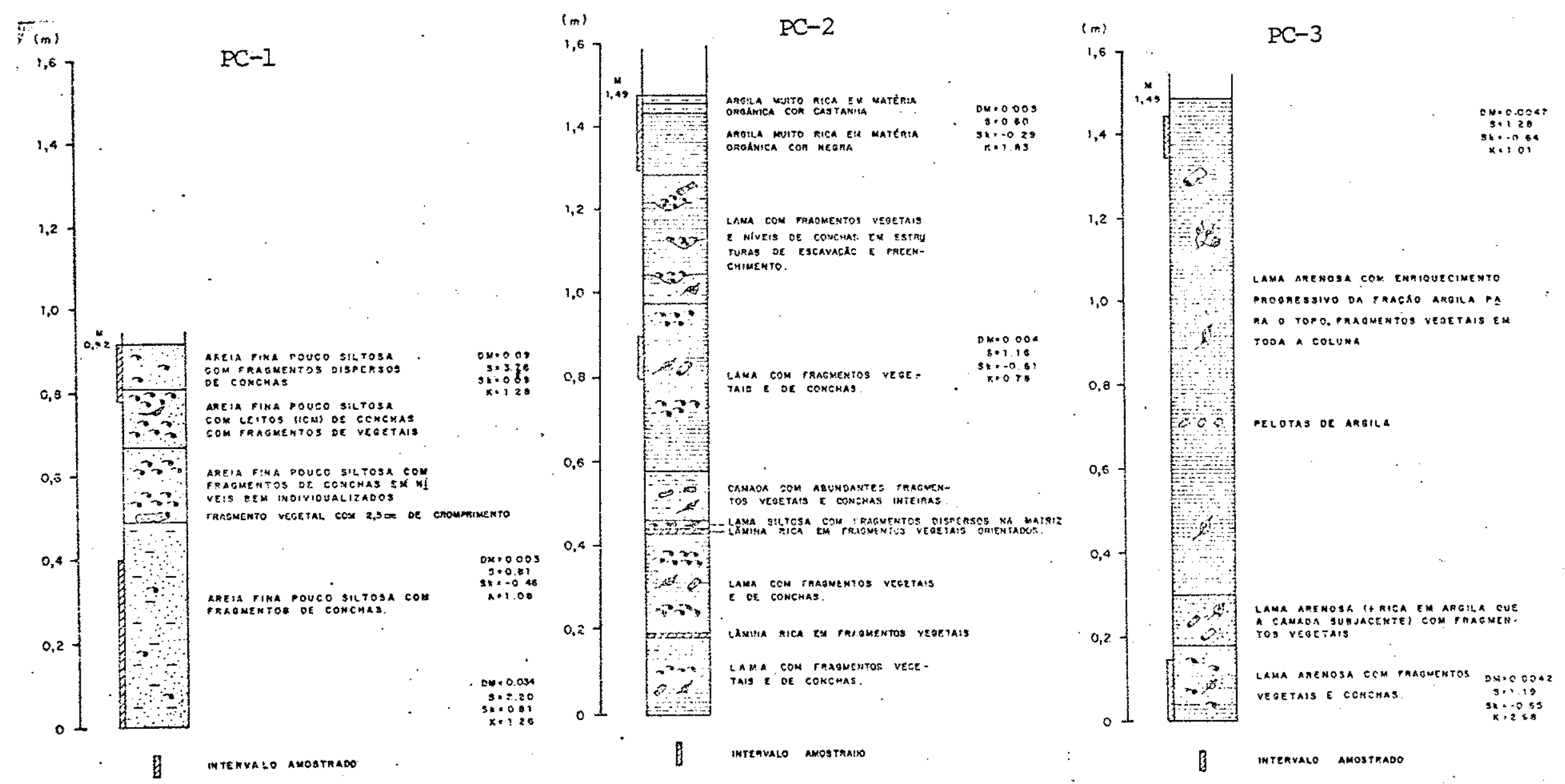

FIGURA 59 - Descrição de testemunhos de cravação rasa, estuário de Santos

(1) (FULFARO et aliz, 1978). 


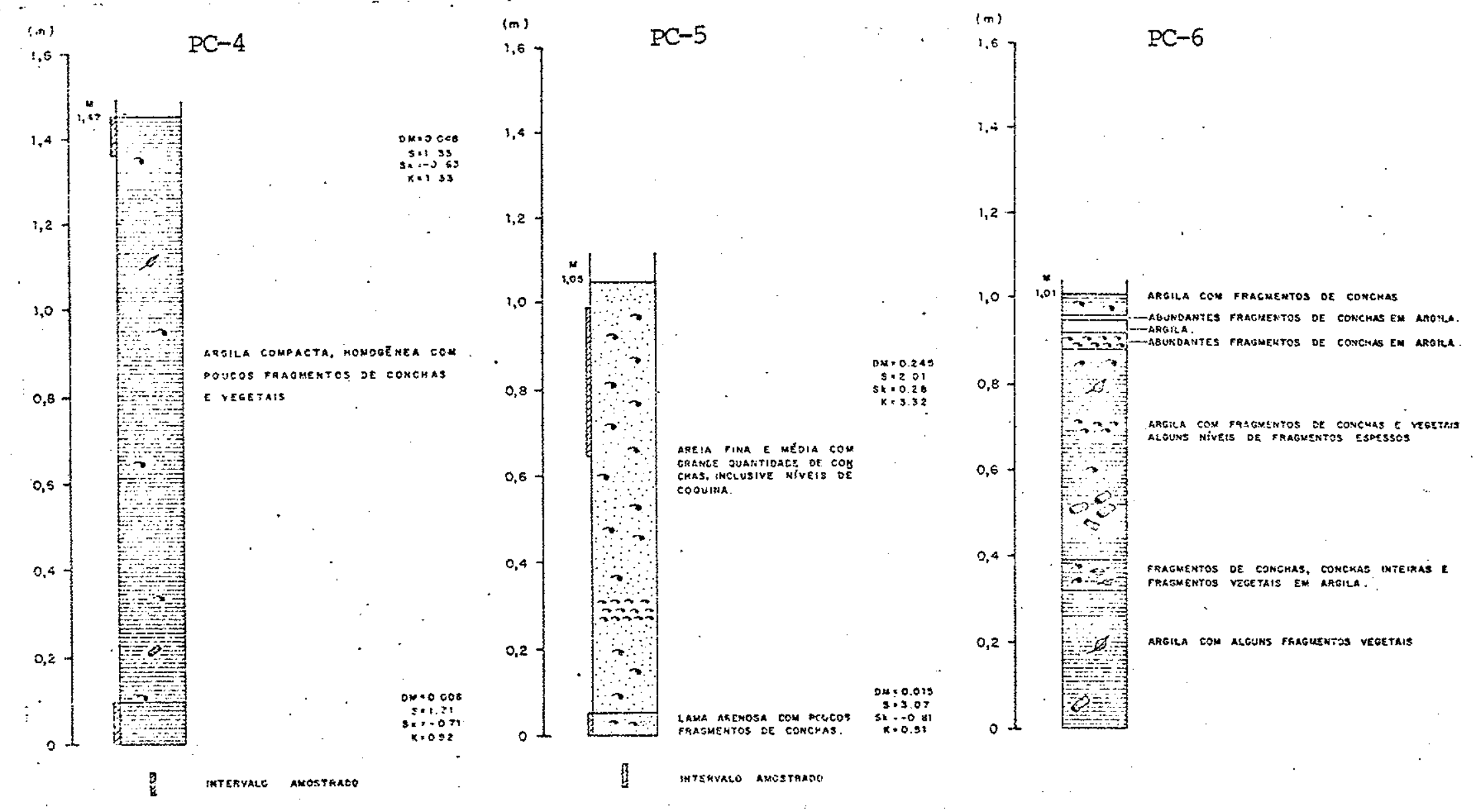

FIGURA 60 - Descrição de testemunhos de cravação rasa, estuário de Santos (2). (FULFARO et alił, 1978). 

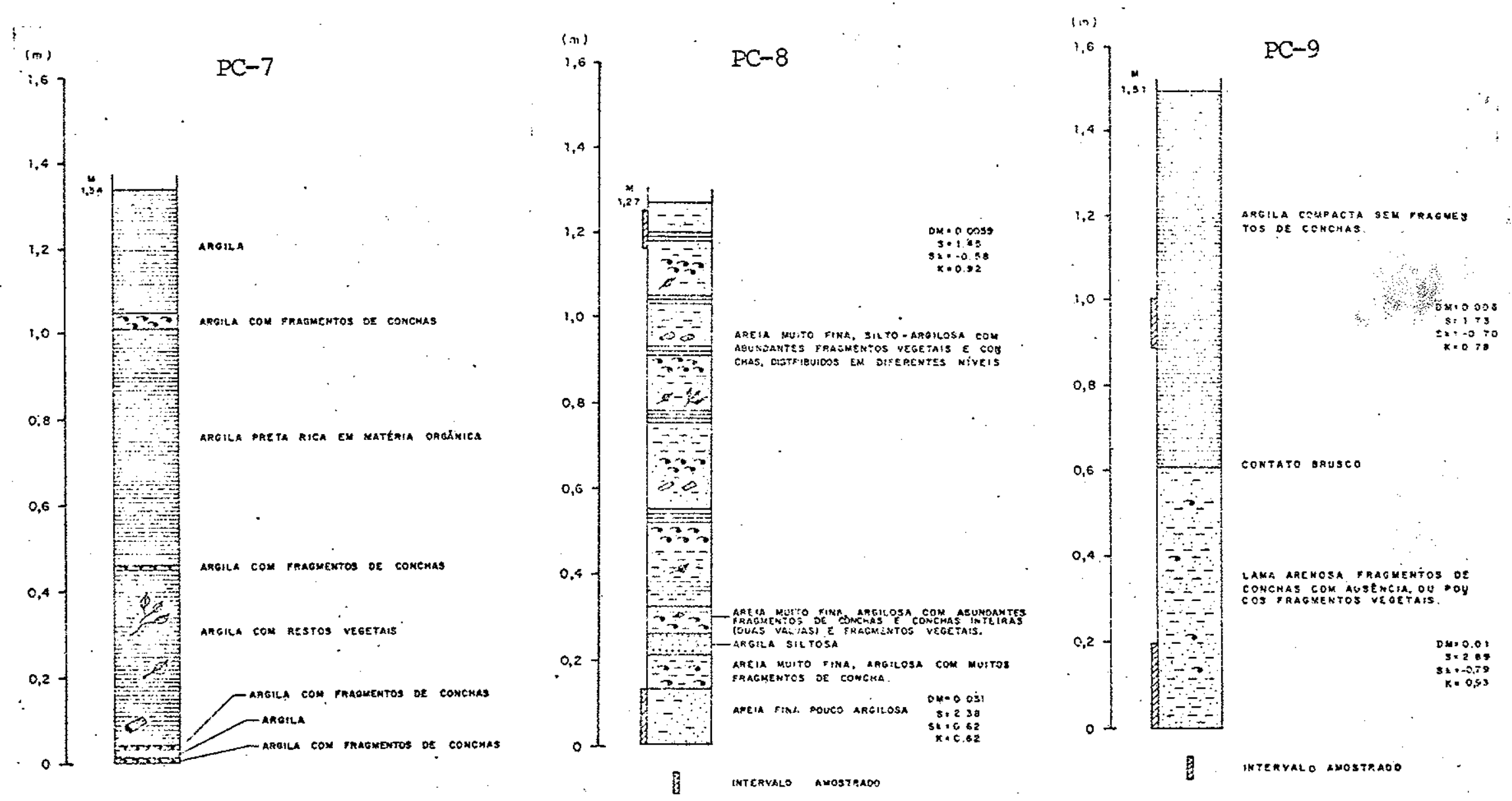

FIGURA 61 - Descrição de testemunhos de cravação rasa, estuário de Santos (3) (FUTí̈ARO et alii, 1978). 

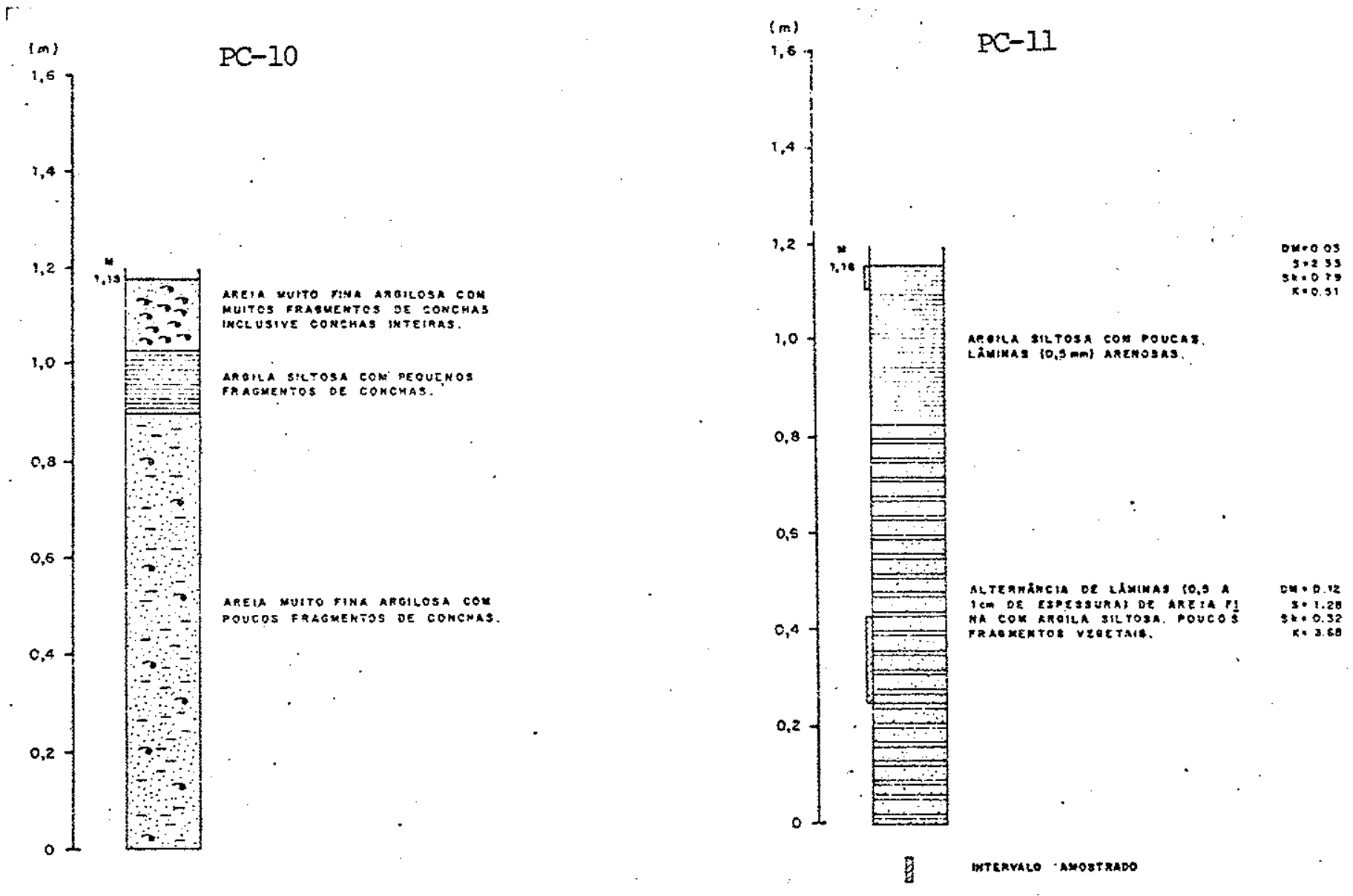

FIGURA 62 - Descrição de testemunhos de cravação rasa, estuário de Santos (4) (FÚtFARO et alii, 1978). 
ratörio. Inicialmente apresenta resultados de estudos ern matexial em suspensão coletado na costa da Nova scôcia e embora não tenha determinado os tipos de argilo-minerais presentes, mostrou que to das as populações granulométricas flocularam de nodo similar. Con clui, em decorrência, que, uma vez em ambiente marinho, todas as partículas dessas populações são instāveis e que, assim, o tamanho das partículas é mais importante que a mineralogia, na floculação. Uma possível explicação sexia de que matêria orgânica ad sorvida obliteraria as propriedades das faces e bordas dos cristais, tornando-os, então, semelhantes fîsico-quimicamente.

o estudo de KRANK (1981) refere-se ao Estuärio de Miramichi, New Brunswick, do tipo micromarê e mistura parcial. Fazendo vâa rios estudos de correlação por regressão, concluj que amostras me nos salinas apresentaram menox floculação, em concordância com es tudos de laboratório. Entretanto, amostras com maiores teores de material em suspensäo flocularam mais que amostras mais salinas $\epsilon$ com menos material em suspensão, sugerindo que a concentração do material eñ suspensão é un dus principais conaicionantes na forma ção de agregados em ambiente estuarino.

Hipoteticamente, a inexistência de floculação permitiria que finos em suspensão fossem para o mar. Entretanto, a combinação de maiores teores de material em suspensão (e consequlentemente maior probabilidade de choque entre particulas) por diminuição de velo cidade de correntes nos estuärios, associadas a mudanças de poten cial eletrolitico, fazem com que ocorra floculação e se deposite material fino preferencialmente no interior dos estuários.

Em resumo, queremos aqui destacar que a deposição de argi las em estuários sob a forma de agregados não diz respeito somen te à simples coagulação eletxolítica, mas envolve tarnbëm o fator choque entre particulas, que por sua vez, depende das frentes de turbidez mäximas. Ora, estas frentes dependem do tipo de circulaÇão estuarina, de modo que acreditamos poder retomar esta questão após a exposição, a ser feita adiante, sobre o modo de circulação do estuärio santista.

F. Salinidade e material em suspensão

Estes dois fatores foram já previamente examinados (EPUSP) DAEs, 1966), visando, o primeiro, a caracterizar a importância da 
floculação no processo de formação de vasas na faixa portuāxia,e, - segundo, a determinar a importância dos sólidos em suspensão no assoreamento desca mesma faixa. Eara tanto foram realizadas cole tas de amostras de āgua em seçöes dos rios Cascalho, Casqueiro. Jurubatuba, Diana-Sandi e Canal da Bertioga, em diversas profundi dades. A amostragem para material em suspensão estendeu-se de 19 de junho de 1964 a 20 de majo de 1966, enquanto que salinidades é velocidades de correntes foram medidas de 18 a 20 de maio de 1966.

os resultados obtidos mostraram valores de salinidades de crescentes em direção ao interior do estuário, variando de 30000 a 22900 p.p.r de sais.

Por outro lado, verificoumse que a variação entre concentra ções de sólidos na enchente e na vazante era minima, e que a in versão de correntes invalidaria cálculos buscando estabelecer pre dominio de transporte num ou noutro sentido; apenas no canal de Bertioga e na embocadura do Diana-Sandi haveria dominância de ma terial em suspensão durante as vazantes, caracterizando então con tribuição mais direta no assoreamenlo destas āreás. Nestos dois casos as concentrações de material em suspensão variaram entre 10 e $200 \mathrm{mg} / 1$, enquanto que nas outras seções estariarn entre 5 e $50 \mathrm{mg} / \mathrm{l}$.

o equilíbrio morfológico regional., associado às baixas con centrações de material em suspensão explicariam as baixas taxas de assoreamento no Canal do Porto; a própria floculação, que te ria lugar nas partes mais altas do estuário, fixaria parte da des carga sólida, propiciando o crescimento dos manguesais.

A proveniência dos sólidos em suspensão seria continental, e a circulação estuarina do tipo curha salina.

procuramos rever o assunto, porëm com abordagem distinta, es sencialmente voltada ao estabelecimento do modo de circulação es tuarina. Para tanto, procedemos a amostragens em situações de preamar e de baixa-mar, em marês de sizígia de 21 e 22 de janeiro de 1985, cobrindo a maior parte dos principais canais do estuário. Realizamos duas seções longitudinaịs: uma descle a barra do porto até a região dos largos, com 14 estações de amostragem, e outra abrangendo o Canal de são Vicente e sua lj.gação com os largos,com 7 estações (FIGURA ). Em cada estação foram coletadas 3 amos tras, a 1 m de superfície, a meia-profundidade, e a $1 \mathrm{~m}$ do fundo, 
designadas pelas letras $T, M \in B$, respectivamente, sendo as pro fundidades estimadas por fio graduado e peso. Levamos ainda em conta que esta amostragem seria representativa de uma situação de verão,e, consequentemente, de maiores descargas fluviais.

A respeito deste ültimo aspecto, tão importante quando se deseja passar da determinação do modelo de circulação à aplicação, não pudemos obter informações mais precisas. Os dados publicados; na área de interesse referem-se a periodo de observações de 1966 a 1970, para uma estação no Rio Cubatão (DAEE, 1974) (FIGURA 64).

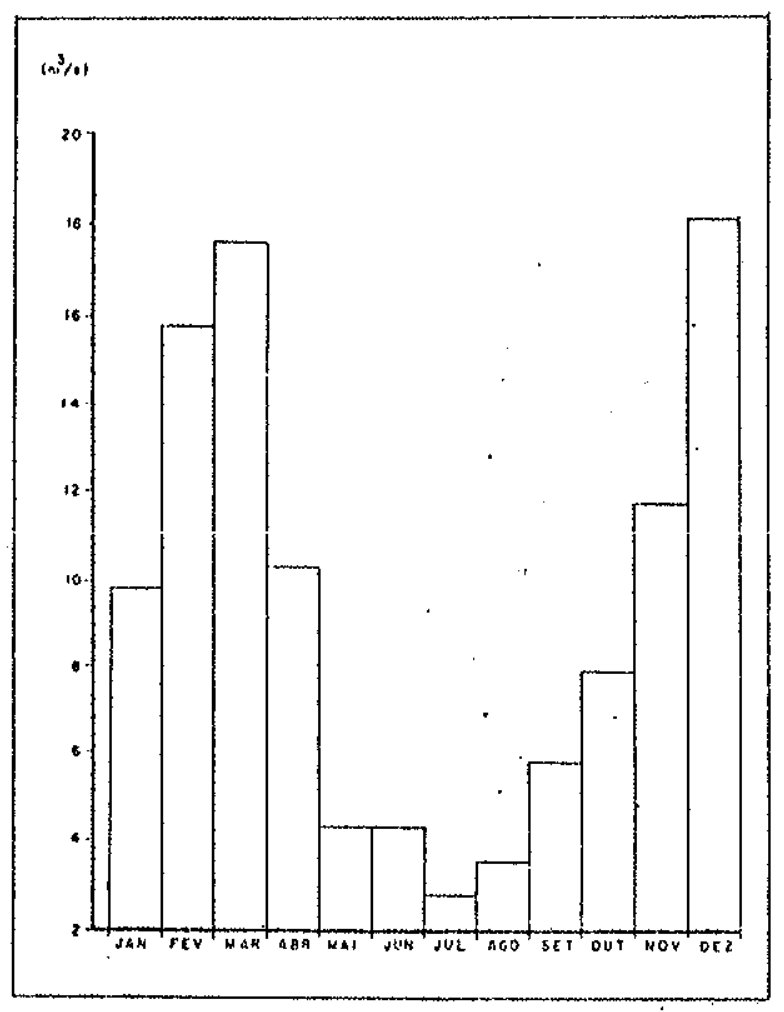

FIGURA 64 - Vazões mëdias mensais do Rio Cubatão entre 1966 e 1970 (DAFE, 1974, p.49).

1. Salinidade

Os valores de salinidades, em equivalentes de NaCl, estão apresentados nas FIGURAs $65^{\circ}$ e $66^{\circ}$. Com eles preparamos as seções de preamar e baixa-mar dos canais do porto e de são Vicente, apresentados nas FIGURAS 67 e 68 .

Ambas as seções do Canal do Porto mostram acentuada estrati ficação ao longo dos poucos mais que $16 \mathrm{~km}$ investigados. Na situa ção de preamar, o estrato inferior apresenta menos que 10 o de va riação māxima de salinidade, desde a foz até o. Largo do canēu; o gradiente de salinidade sofre brusca variação na isocurva de 


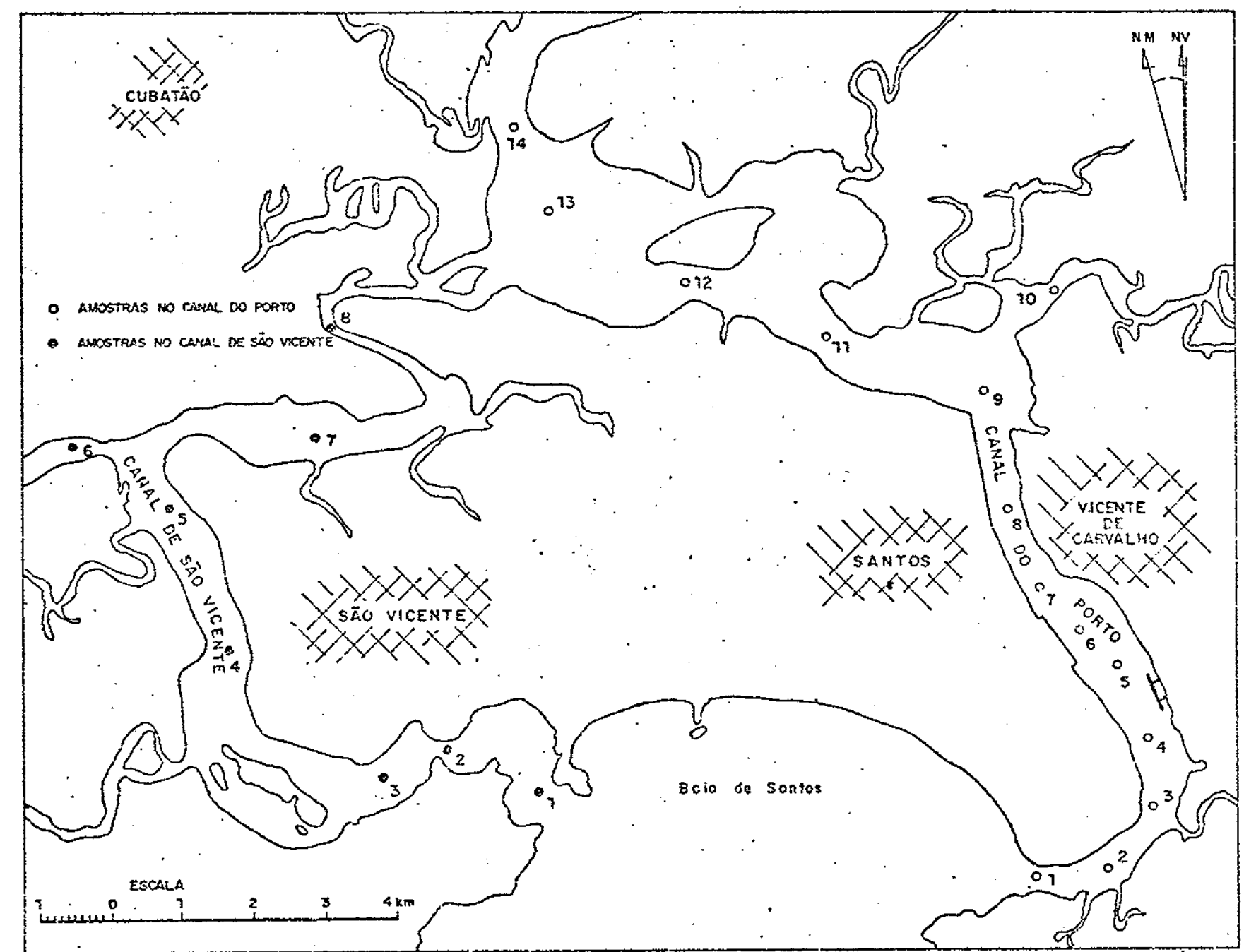

FIGURA 63 - Localização das estações dee coleta de água - Santos 


\begin{tabular}{|c|c|c|c|c|c|c|c|}
\hline \multicolumn{4}{|c|}{ PREAMAR } & \multicolumn{4}{|c|}{ BAIXA-MAR } \\
\hline Amostra & $\begin{array}{c}\text { Salinidade } \\
\text { (p.p.m. de } \mathrm{NaCl})\end{array}$ & Amostra. & $\begin{array}{c}\text { Salinidade } \\
\text { (p.p.m. de NaCl) }\end{array}$ & Anostra & $\begin{array}{c}\text { Salinidaäe } \\
\text { (p.p.m. de } \mathrm{NaCl})\end{array}$ & Amostra & $\begin{array}{c}\text { Salinidade } \\
\text { (p.p.m. de NaCl) }\end{array}$ \\
\hline $1 T$ & 23000 & $8 \mathrm{~T}$ & 18000 & $I T$ & 24000 & $8 T$ & 17500 \\
\hline$I M$ & 29. 000 & $8 \mathrm{M}$ & 28000 & $1 \mathrm{M}$ & 28000 & $8 \mathrm{M}$ & 27000 \\
\hline $1 \mathrm{~B}$ & 29500 & $8 \mathrm{~B}$ & 29500 & $1 \mathrm{~B}$ & 29000 & $8 \mathrm{~B}$ & 28000 \\
\hline $2 \mathrm{~T}$ & 23000 & $9 \mathrm{~T}$ & 17500 & $2 T$ & 20000 & $9 \mathrm{~T}$ & 16000 \\
\hline $2 \mathrm{M}$ & 27000 & $9 M$ & 28000 & $2 \mathrm{M}$ & 27000 & $9 M$ & 28000 \\
\hline $2 B$ & 28000 & $9 \mathrm{~B}$ & 29000 & $2 \mathrm{~B}$ & 28000 & $9 B$ & 28000 \\
\hline $3 \mathrm{~T}$ & 19500 & $10 T$ & 14000 & $3 T$ & 19500 & $10 T$ & 15500 \\
\hline $3 M$ & 29000 & $10 \mathrm{M}$ & 23000 & $3 \mathrm{M}$ & 29000 & IOM & $16.000^{\circ}$ \\
\hline $3 B$ & 29500 & $10 B$ & 24000 & $3 B$ & 29000 & $10 B$ & 18000 \\
\hline $4 T$ & 20500 & $11 T$ & 17000 & $4 T$ & 19500 & $11 \mathrm{~T}$ & 14000 \\
\hline $4 M$ & 28000 & $11 \mathrm{M}$ & 27000 & $4 \mathrm{M}$ & 26500 & $I I M$ & 27000 \\
\hline $4 B$ & 29500 & $I I B$ & 28000 & $4 B$ & 29000 & $11 \mathrm{~B}$ & 27500 \\
\hline $5 \mathrm{~T}$ & 22500 & $12 \mathrm{~T}$ & 14500 & $5 T$ & 18000 & $12 \mathrm{~T}$ & 12000 \\
\hline $5 \mathrm{M}$ & 27000 & $12 M$ & 27000 & $5 \mathrm{M}$ & 27000 & $12 \mathrm{M}$ & 27500 \\
\hline $5 B$ & 29000 & $12 \mathrm{~B}$ & 28000 & 58 & 29000 & $12 \mathrm{~B}$ & 28000 \\
\hline $6 \mathrm{~T}$ & 19500 & $13 \mathrm{~T}$ & 13000 & $6 \mathrm{~T}$ & 17500 & $13 T$ & 10000 \\
\hline $6 \mathrm{M}$ & 28000 & $13 \mathrm{M}$ & 27000 & $6 \mathrm{M}$ & 27500 & $13 \mathrm{M}$ & 24500 \\
\hline $6 \mathrm{~B}$ & 29000 & $13 \mathrm{~B}$ & 27000 & $6 \mathrm{~B}$ & 29000 & $13 \mathrm{~B}$ & 27000 \\
\hline $7 \mathrm{~T}$ & 19000 & $14 \mathrm{~T}$ & 14500 & $7 m$ & 28000 & $14 \mathrm{~T}$ & 10500 \\
\hline $7 M$ & 29000 & $14 \mathrm{M}$ & 27000 & $7 \mathrm{M}$ & 29000 & $14 \mathrm{M}$ & 23500 \\
\hline $7 B$ & 29500 & $14 \mathrm{~B}$ & 27500 & $7 B$ & 29000 & $14 \mathrm{~B}$ & 27500 \\
\hline
\end{tabular}

EIGURA 65 - Valores de salinidade no Canal do Porto, em situaçc̃es de preamar e baixa-mar. 


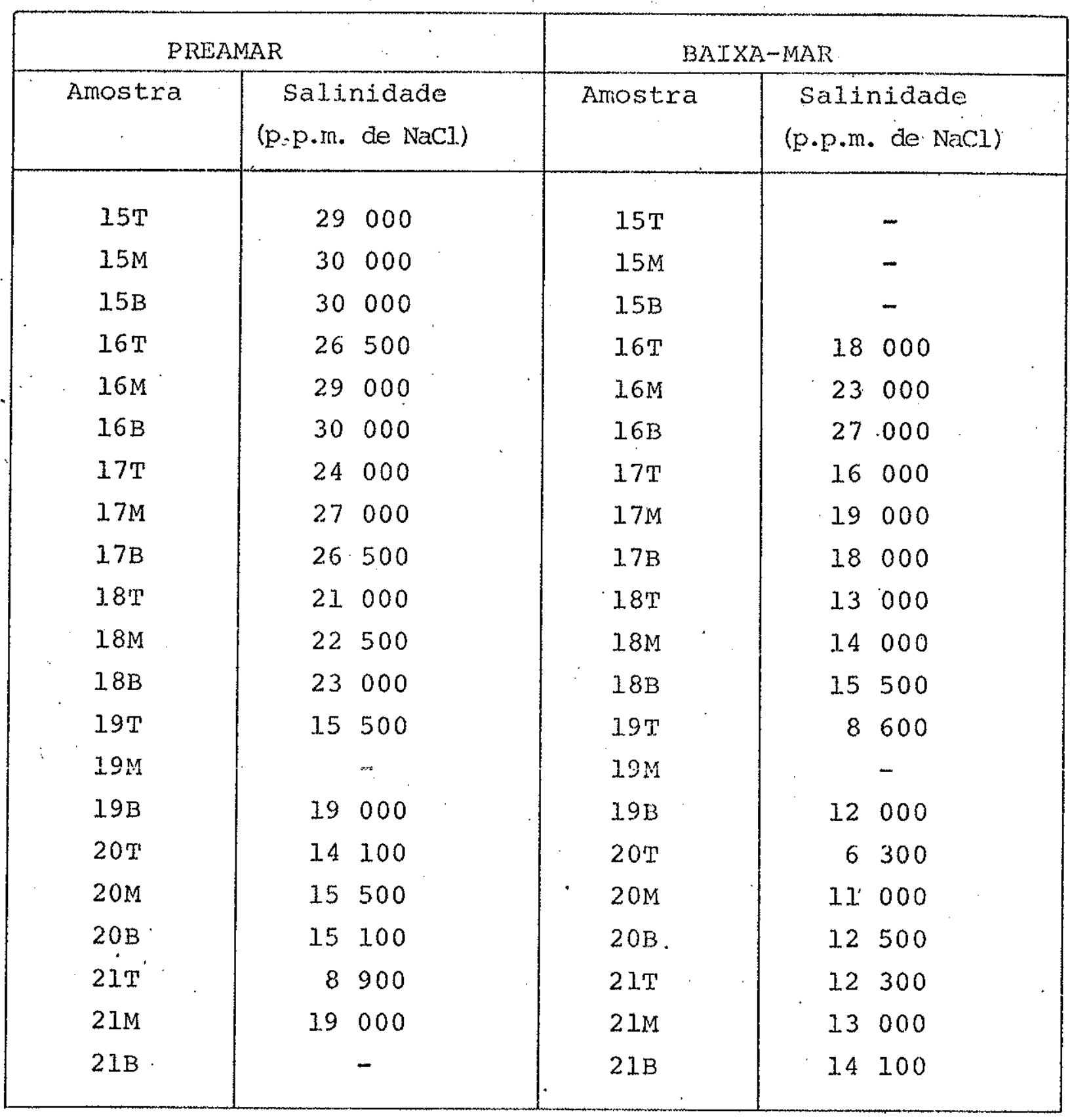

FIGURA 66-Valores de salinidade no Canal de São Vicente em situações de preamar e baixa-mar. 


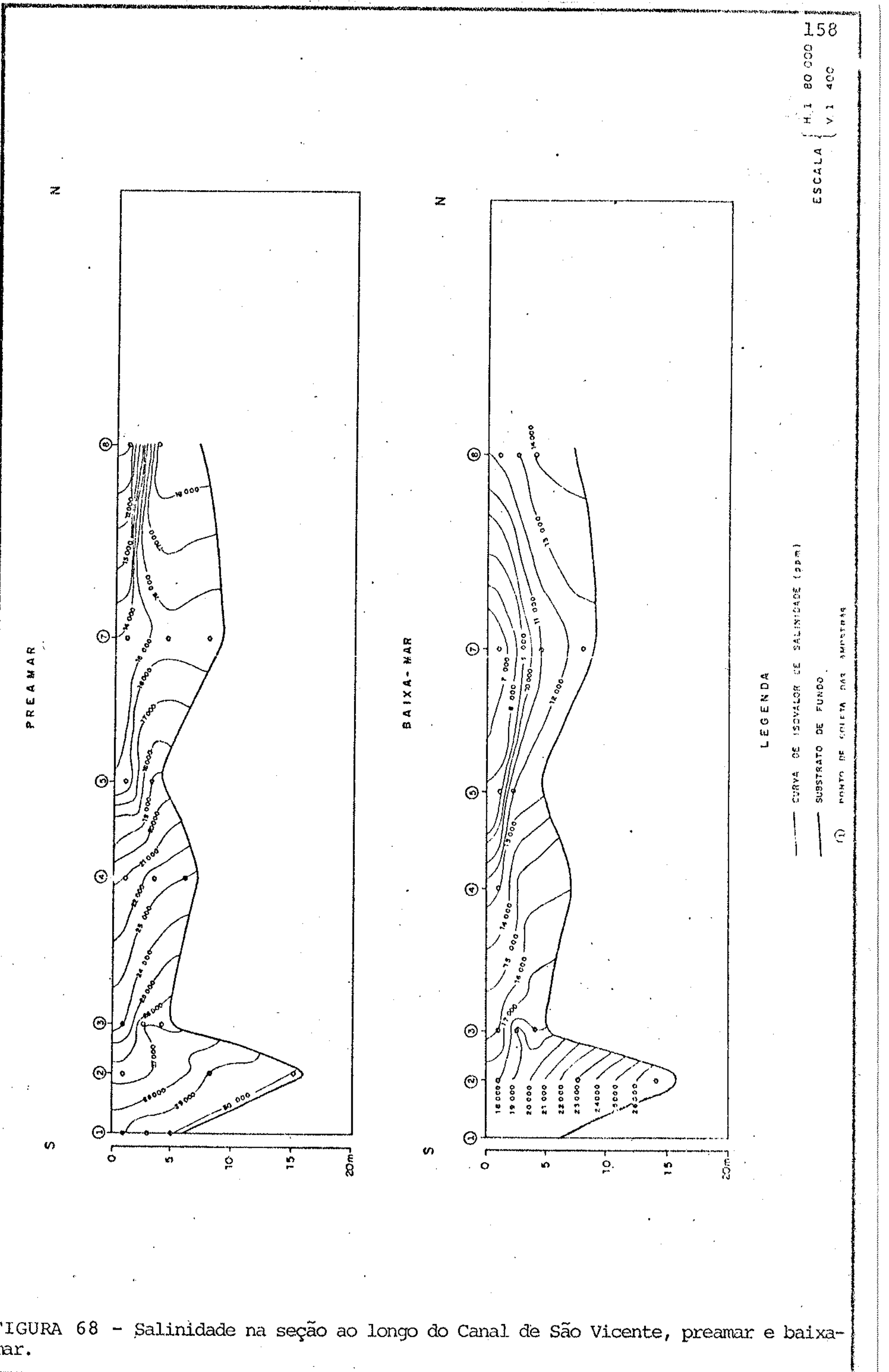


27000 p.p.m. de NaCl.

Na baixa-mar a situação é semelhante, tambēm balizada pela isocurva de 27000 p.p.m de NaCl. Entretanto, a montante da esta ção 12, no Largo do Canēu, a camada inferior tende a desaparecer, aproximando-se seu valor de salinidade do da camada superior. E ainda nesse mesmo setor que se observa ligeira diminuição de sali nidades da camada superior, comparativamente à situação de prea mar.

Para as duas situações, preamar e baixa-mar, pode-se consta tar mistura de água salgada e água doce, pouco pronunciada no es trato inferior, e maior no superior. Em nenhum dos dois casos se configura um gradiente mais acentuado, definido por alguma varja ção mais brusca nas curvas.

Bem diversa é a situação ao longo do Canal de são Vicente, em que as salinidades são nitidamente maiores na preamar que na baixa-mar. Em ambas as situações alguma estratificação, mais ní tida na preamar, começa a se esboçar apenas a montante da estação

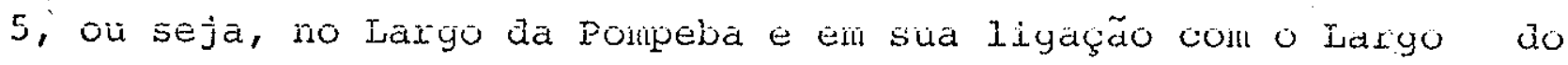
Canēu. No demais, os valores de salinidade aumentam progressiva mente de juzante para montante, caracterizando uma mistura mais efetiva de àguas doce e salgada.

2. Material em suspensão

Os teores de material em suspensão foram obtidos somente pa ra a seção ao longo do Canal do Porto, e acham-se apresentados na FIGURA 69.

Provavelmente a constatação mais notável que se pode fazer, de inicio, refere-se aos baixos teores de sólidos em suspensão, que se mantêm, em sua maior parte, na mesma faixa de valores obti dos em 1964-1966 (EPUSP/DAEE, 1966). Tal fato parece denotar o propalado equilíbrio do estuärio santista (EPUSP/DAEE, 1966;FULFA RO \& PONÇANO,1976), apesar de intensificações temporārias de ta xas regionais de erosão por implantação de obras viārias, explora ção de materiais de construção e degradação da cobertura vegetal da Serra do Mar, que vêm ocorrendo justamente nesse período de 1966 a 1985 .

A distribuição do material em suspensão em situaçöes de preamax e baixa-mar, pode ser visualizada na FIGURA 70 . 


\begin{tabular}{|c|c|c|c|}
\hline \multicolumn{2}{|c|}{ PREAMAR } & \multicolumn{2}{|c|}{ BAIXA-MAR } \\
\hline Amostra & $\begin{array}{c}\text { Material, em } \\
\text { Suspemsão } \\
\text { mg/l }\end{array}$ & Amostra & $\begin{array}{c}\text { Material em } \\
\text { Suspensão } \\
\text { mg/l }\end{array}$ \\
\hline $\begin{array}{l}1 \mathrm{~T} \\
1 \mathrm{M} \\
1 \mathrm{~B} \\
2 \mathrm{~T} \\
2 \mathrm{M} \\
2 \mathrm{~B} \\
3 \mathrm{~T} \\
3 \mathrm{M} \\
3 \mathrm{~B} \\
4 \mathrm{~T} \\
4 \mathrm{M} \\
4 \mathrm{~B} \\
5 \mathrm{~T} \\
5 \mathrm{M} \\
5 \mathrm{~B} \\
6 \mathrm{~T} \\
6 \mathrm{M} \\
6 \mathrm{~B} \\
7 \mathrm{~T} \\
7 \mathrm{M} \\
7 \mathrm{~B} \\
8 \mathrm{~T} \\
8 \mathrm{M} \\
8 \mathrm{~B} \\
9 \mathrm{~T} \\
9 \mathrm{M} \\
9 \mathrm{~B} \\
10 \mathrm{~T} \\
10 \mathrm{M} \\
10 \mathrm{~B} \\
11 \mathrm{~T} \\
11 \mathrm{M} \\
11 \mathrm{~B} \\
12 \mathrm{~T} \\
12 \mathrm{M} \\
12 \mathrm{~B} \\
13 \mathrm{~T} \\
13 \mathrm{M} \\
13 \mathrm{~B} \\
14 \mathrm{~T} \\
14 \mathrm{M} \\
14 \mathrm{~B} \\
\end{array}$ & 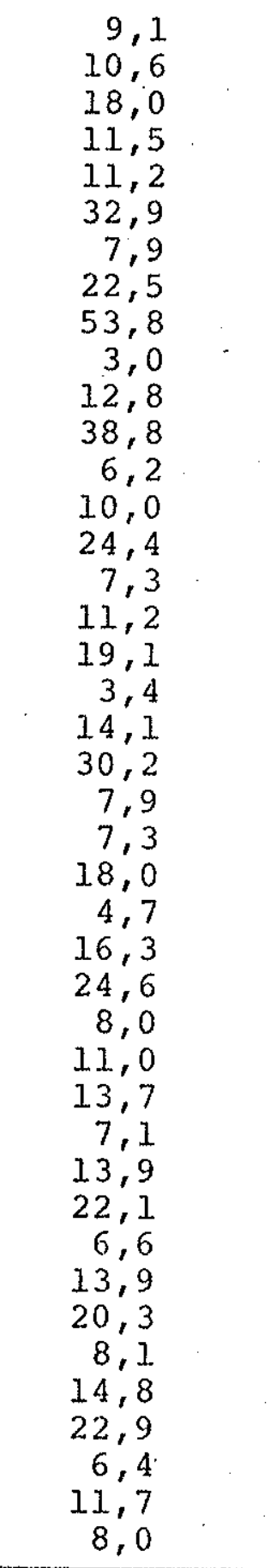 & $\begin{array}{l}1 \mathrm{~T} \\
1 \mathrm{M} \\
1 \mathrm{~B} \\
2 \mathrm{~T} \\
2 \mathrm{M} \\
2 \mathrm{~B} \\
3 \mathrm{~T} \\
3 \mathrm{M} \\
3 \mathrm{~B} \\
4 \mathrm{~T} \\
4 \mathrm{M} \\
4 \mathrm{~B} \\
5 \mathrm{~T} \\
5 \mathrm{M} \\
5 \mathrm{~B} \\
6 \mathrm{~T} \\
6 \mathrm{M} \\
6 \mathrm{~B} \\
7 \mathrm{~T} \\
7 \mathrm{M} \\
7 \mathrm{~B} \\
8 \mathrm{~T} \\
8 \mathrm{M} \\
8 \mathrm{~B} \\
9 \mathrm{~T} \\
9 \mathrm{M} \\
9 \mathrm{~B} \\
10 \mathrm{~T} \\
10 \mathrm{M} \\
10 \mathrm{~B} \\
11 \mathrm{~T} \\
11 \mathrm{M} \\
11 \mathrm{~B} \\
12 \mathrm{~T} \\
12 \mathrm{M} \\
12 \mathrm{~B} \\
13 \mathrm{~T} \\
13 \mathrm{M} \\
13 \mathrm{~B} \\
14 \mathrm{~T} \\
14 \mathrm{M} \\
14 \mathrm{~B}\end{array}$ & $\begin{array}{r}4,6 \\
19,5 \\
59,0 \\
7,2 \\
6,0 \\
112,8 \\
6,1 \\
6,4 \\
13,6 \\
5,1 \\
8,1 \\
17,8 \\
7,5 \\
12,6 \\
23,2 \\
8,5 \\
12,7 \\
12,0 \\
10,5 \\
10,1 \\
29,1 \\
8,9 \\
12,5 \\
50,0 \\
7,5 \\
16,6 \\
21,7 \\
7,1 \\
10,7 \\
15,6 \\
8,9 \\
11,4 \\
10,7 \\
8,2 \\
9,1 \\
9,3 \\
9,3 \\
7,9 \\
8,1 \\
8,1 \\
5,9 \\
5,6\end{array}$ \\
\hline
\end{tabular}

FIGURA 69 - Teores de material em suspensão no Canal do Porto em situações de preamar e baixa-mar. 
$z$

(2)

(2)

$\theta$

(a)
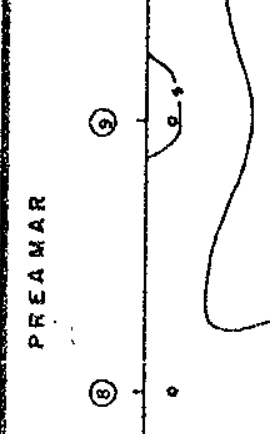

$\Theta$

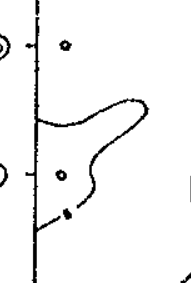

(e)

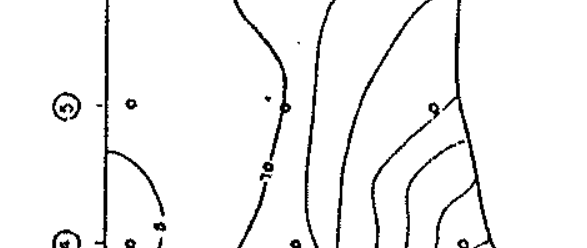

()

(a)

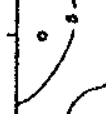

(a) $\{0$

e.

$\Theta$

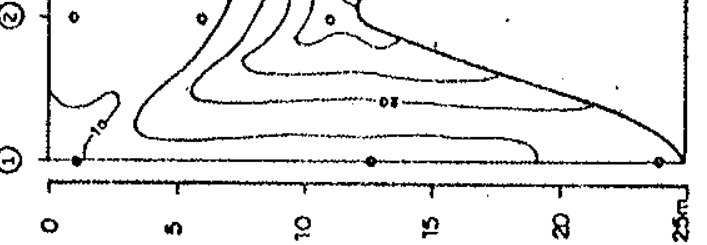

2

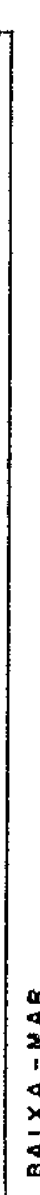

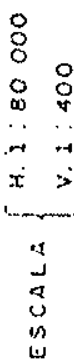

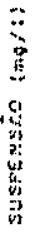

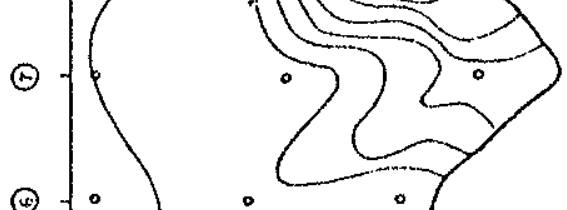

3

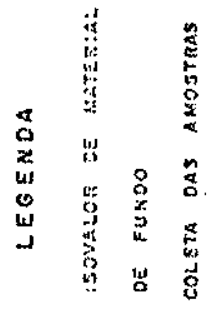

4 웅

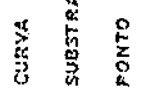
11 
Nas duas situaçöes nota-se que as majores concentraçöes 5 tuam-se ao longo de toda a seção com teores superiores a $10 \mathrm{mg} / 1$, enquanto que em baixa-mar a curva de $10 \mathrm{mg} / 1$ fecha à altura do Largo do Canéu. Este padrão é sugestivo de que, exatamente onde os valores de salinidade indjcavam maior influência de água doce (Largo do Canēu em baixa-mar), há menos sôlidos em suspensão, o que leva a supor em princípio que o aporte sölidos em suspensão de origem continental é menor que o de origem marinha.

\section{G. Circulação estuarina}

A literatura indica que os dois parâmetros mais caracterís ticos da circulação estuarina são as distribuições de salinidades e de velocidades de corrente (cf. BOWDEN, 1967).

para a porção do estuärio santista abrangida por nossa se ção ao longo do Canal do Porto até o Largo do Canēu, recorremos a duas séries de medições de velocidades de correntes apresentadas no trabalho da EPUSP/DAEE (1966), realizadas na Ponta da praialCa nal do Porto) e à altura da I.lha Barnabé, nas proximidades das es tações 1 e 10, respectivamente. Atravēs de consulta à tābua de ma rés de 1966, selecionamos as horas de medições mais prōximas de situações de preamar e baixa-mar.

Adimitimos também mudança no sentido da corrente, apōs ter esta atingido velocidade nula, com o que pudemos construir os grá ficos da FIGURA 71, em que representamos tambëm as.médias de sa linidades.

Entre os quatro tipos básicos de circulação estuarina apre sentados por BOWDEN (1967), quais sejam, cunha salina, estratifi cado com aporte (two-layex flow with entrainement), estratificado com mistura vertical (two-zayer flow with vextical mixing) e verticalmente homogêneos, é ao terceiro que podemos melhor assimi lar o trecho do estuário santista na seção Canal do porto / Largo do canëu. o segundo tipo, que poderia ser tambëm cogitado, è ca racteristico dos fiordes, em que a mistura de äguas doce e salga da ocorre exclusivamente no estrato superior.

Assim, a mencionada seção do estuärio santista teria padrão de circulação similar ao rio Tâmisa. Neste tipo de estuārio, não hā uma nítida separação entre āguas doce e salgada, e sim um au mento continuo de salinidade em direção ao fundo, sendo que o mä 
ximo gradiente de salinidade ocorre na região de velocidades nu las, situação bem caracterizada para a preamax na FIGURA 71.

No caso da seção Canal de são Vicente/Largos, não dispomos de medidas de velocidades de corrente. Entretanto, neste caso,não há dúvida que, na maior parte da seção, o gradiente de salinidades é quase horizontal, caracterizando então uma circulação do ti. po verticalmente homogênea. Conforme jā notāramos, na região dos largos, hã uma tendência à maior estratificação, tanto em preamar como em baixamar (FIGURA 67 e 68 ).

Procuramos a seguir verificar quais as implicações mais di retas do modelo de circulação da seção Canal do porto/Largo do Ca néu na distribuição do material em suspensão, por meio de correla-ção entre salinidades e teores de material em suspensão.

Para todos os dados, obtivemos coeficiente de correlação de 0,72 em situação de preamar, e de 0,44 em baixa-mar (FIGURAs 72 e 73)

Procedemos a seguir à correlação entre esses dois fatores, para os trés niveis amostrados ( $T$, $M \in B)$. Obtivemos as scguintos correlações em preamar: $\mathrm{T}=0,20 ; \mathrm{M}=0,30 ; \mathrm{B}=0,43$; em baixa max os valores foram: $T=0,62, M=0,49, B=0,43$.

Verificamos assim què a distribuição do material em suspen são não guarda relação dixeta com a estratificação do estuärjo . procedemos então as novas correlações entre salinidaes e teores de material em suspensão, desta vez abrangendo três setores do es tuạrio: um próximo à foz, compreeendendo as estações 1 a 5 , um in termediário, estações 6 a 9, e outro interior, estações 11 a 14 .

Desta feita obtivemos as correlações de jusante para montan te de: $0,78,0,83$ e 0,83 em preamar, e de $0,62,0,77$ e 0,3 em bai xa-mar (FIGURAS 74 e 75 ).

Esses resultados mostram que a melhor correlação observada na preamar para todas ás amostras, se mantëm. Adicionalmente no ta-se que a menor correlação global da baixa-mar decorre de maior dispersão do material em suspensão na região dos largos, coinci dentemente com uma tendência à homogenejzação do gradiente de saIinidades, conforme expusēramos anteriormente.

No conjunto podemos concluir que na preamar o estuário apre senta-se melhor definido quanto a velocidades de corrente, salini 


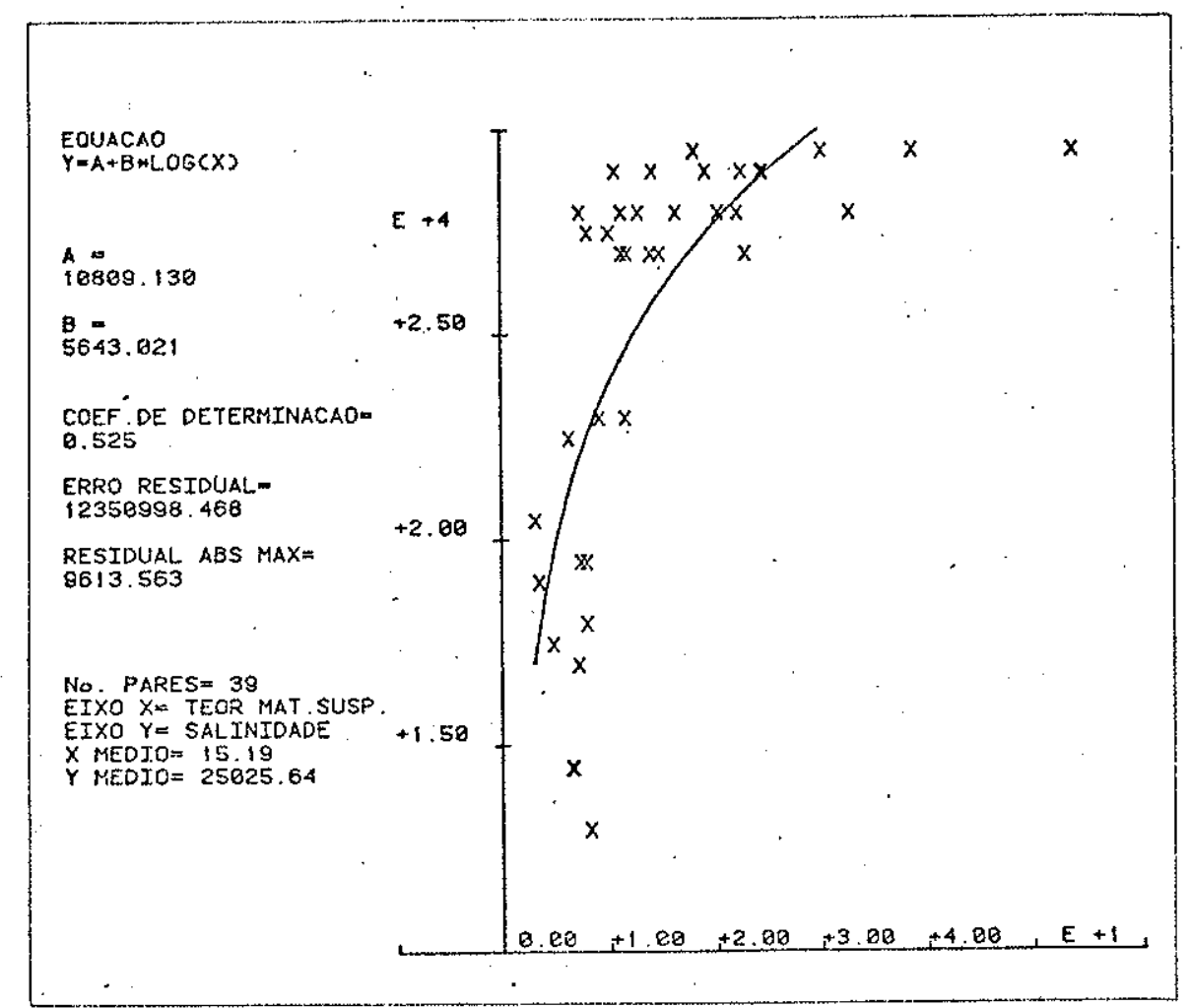

FIGURA 72 - Correlação entre salinidades e teores de material em suspensão, preamar, seção Canal do Porto - Largo do Canéu.

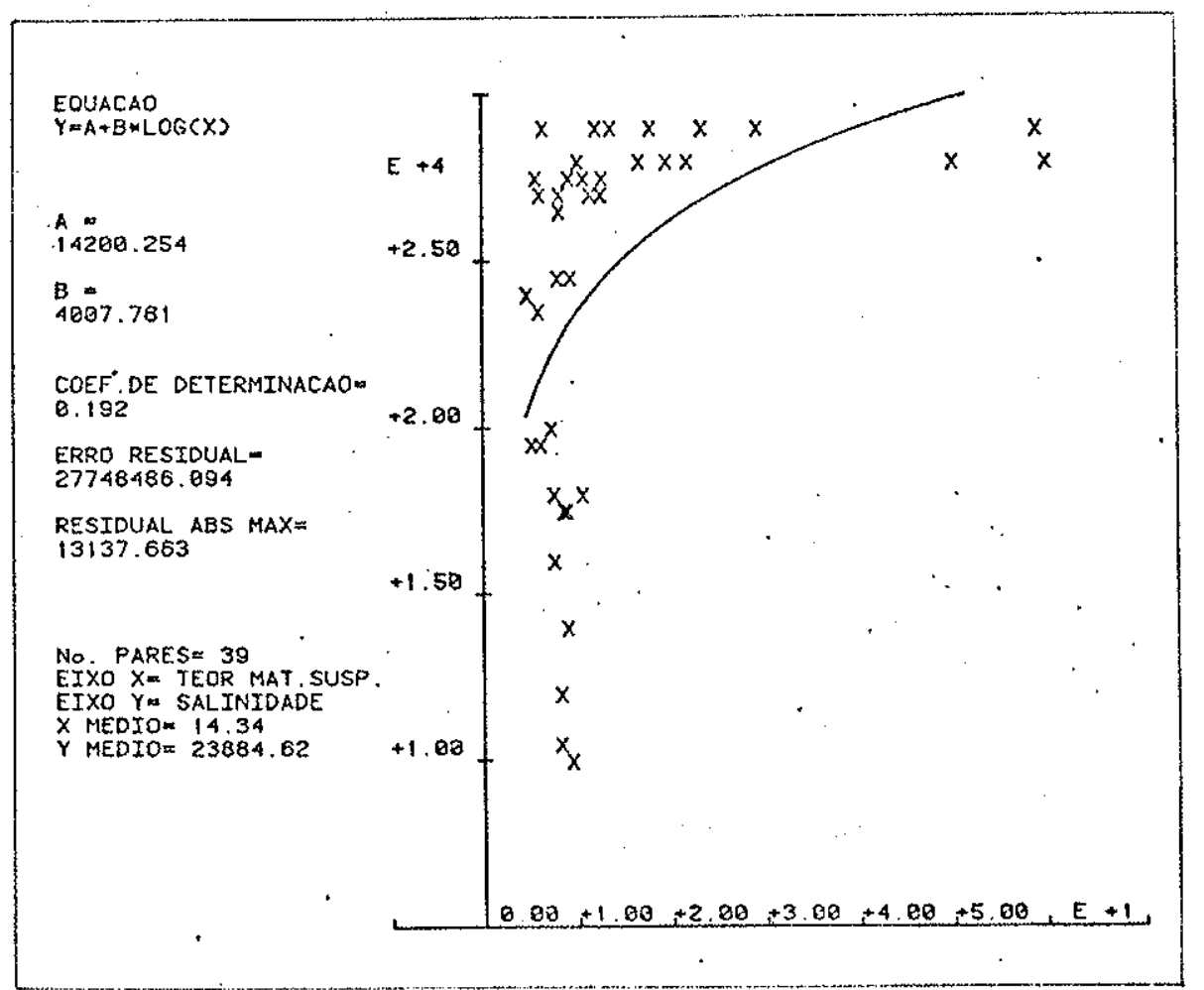

EIGURA 73 - Correlação entre salinidades e teores de material em suspensão, baixa-mar, seção Canal do Porto - Largo do Canēu. 

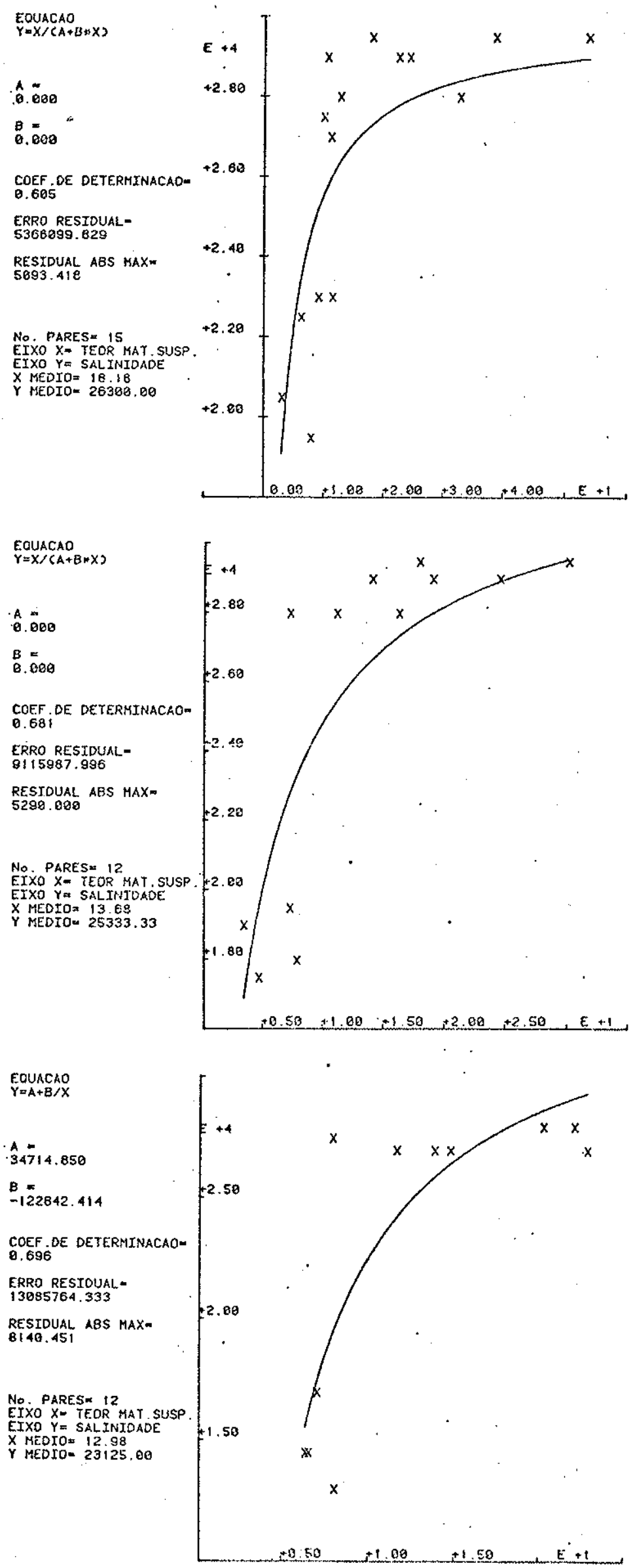

FIGURA 74 - Correlações salinidades $x$ teores de material em suspensão para três setores da seção Canal do Porto-largo do Canêu, em preamar. 

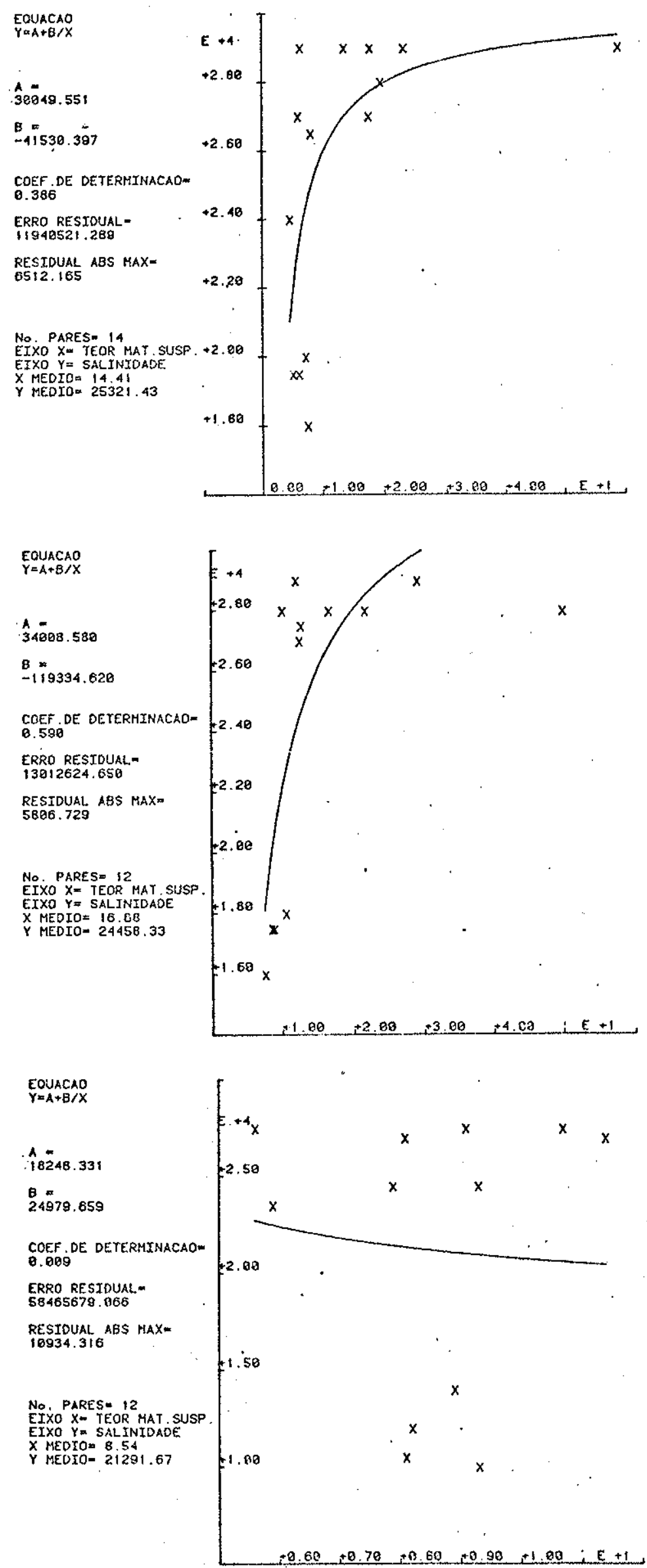

FIGURA 75 - Correlaçōes salinidades $x$ teores de material em suspensão para três setores da seção Canal do Porto-Largo do Canéu, em baixa-mar. 
dade e material em suspensão. Na baixa-mar sua estruturação é me nor, havendo entretanto ainda boa definição de dois estratos e boa correlação destes com os teores de material em suspensão, ao longo do Canal do Porto; na região dos largos, a correlação é mui to baixa.

Há portanto uma certa mudança na dispersão dos sölidos em suspensão nessas duas situações, que pode ser associada à maior ou menor penetração de ägua marinha para o interior do estuário, conforme se esteja em preamar ou em baixa-mar.

Há que analisar ainda a distribução dos sólidos em suspensão do estuário, com relação a seu elemento complementar, a baía. As sim, haviamos proposto; ao discutirmos as caracteristicas dos se dimentos de superficie de fundo, que material em suspensão proveniente da deriva litorânea poderia dirigir-se do setor oeste da baía para o estuário. Parece-nos então que o padrão de àistribui ção e teores de material em suspensão no interior do estuärios, conforme expusemos, vem a concordar com essa fonte marinha para os sỏlidos em suspensão.

Entretanto, não se pode deixar de considerar que o tipo de estratificação do estuārio tambēm implica em que, dada a mistura parcial de äguas, haja material em suspensão de origem continental nas partes mais profundas do estuārio.

Pode-se então concluir que, nas condições de descarga flu vial e marés investigadas, a zona de turbidez máxima do estuārio santista estende-se ao longo do Canal do Porto, entre as estações 1 e 9 (FIGURA 70), sendo formadạ essencialmente por sólidos em suspensão provenientes preferencialmente da plataforma continen tal. Efeitos de ressuspensão podem ocorrer, possivelmente mais na baixa-mar, conforme sugere a distribuição de curvas de isovalores de material em suspensão e velocidades para essa situação. Comple mentarmente deve-se notar que os teores de sölidos em suspensão são relativamente baixos, o que indica que a zona de tuxbidez má xima possa exercer seu efeito a longo prazo, o que pode ser con tornado por dragagens.

Outro fator a ser novamente considerado é o da agregação de particulas, sob o ponto de vista da zona de turbidez máxima e do modelo de circulação. Este último dado, no caso em questão, mos 
tra considerável aporte de água maxinha para o interior do estuä rio, àaltura dos largos; isto implica que, do ponto de vista ele trolitico, hä condições de precipitação de flocos nessa região.

Levando em conta, como jä.se notara anteriormente (EPUSP) DAEE, 1966), que é nessa faixa dos largos que se estendem os man guesais, pode-se concluir que os sólidos de origem fluvial ficam preferencialmente a retidos por 1) quebra de gradjente fluvial, perda de energia do meio transportador e consequente deposição das fxações granulométricas mais grossas; 2) coagulação eletrolítica das frações finas; 3) fixação do material assim depositado por efeito tanto físico (coesão, velocidades críticas de deposição e erosão) 'como biológico (crescimento de vegetação do mangue).

o esquema acima esbòçado é bastante simplificado; na verãde parte do material firo não se fixa de imediato. Ademais hä. que considerar que as correntes associadas à circulação estuarina devem tex competência para não só manter sólidos em suspensão como ainda para promover ressuspensão.

Entre a região do alto estuầrio e o Canal do Porto, nos lar gos, estende-se uma região caracterizada por bajxos teores de ma terial em suspensão. Nessa região, tanto o fator deposicional fi sico-quimico ligado à"salinidade das äguas jä foj ultrapassado; como ainda não hã condições especialmente favoräveis a aumento de choques entre as particulas, dadas suas baixas concentrações.

Em dẹcorrência, somente na porção texminal do Canal do por to voltam a haver conaições mais favoráveis à agregação de particulas, desta vez devido a aumentos locajs de concentrações de sô lidos em suspensão, na zona de turbidez mäxima. Nesse sentido, as amostras de cravạ̧ão rasa coletadas no Canal do porto (amostras 9 e 10, FIGURA 61) não mostram caracteristicas texturais que indiquem ser a agregação de finos fator importante nessa região.

podemos então concluir, no que diz respeito à agregação de partículas', quẹ, no caso de Santos, o padrão de circulação estuarina é o fator determinante.

IV ESTUARTO DO TIAJAI-AÇU

o porto de Itajaj-Açu atende, basicamente, ao Estado de San ta Catarina, conjuntamente com o Porto de São Francisco do Sul, ve 
rificando-se certa especialização nesses portos, com predomínio de carga geral no primeiro, e granéis no segundo (PORTOBRĂS, 1979).

Desenvolvemos no estuārio do Itajaí-Açu três campanhas de reconhecimento e amostragem, visando sobretudo contribuir para a compreensão de seu regime, e elucidar alguns aspectos do assoreamento que aí se verifica, em especial a origem dos sedimentos que - causam se fluviais, se marinhos.

Os sedimentos de superficie de fundo foram abordados do pon to de vista de sua distribuição sazonal, para tanto tendo sido de senvolvidos duas campanhas, de acordo com a vazão do Itajaj-Ā̧u. . os sedimentos em suspensão foram coletados numa campanha especial, quando se refez tambëm parte da amostragem de superfície de fundo, para possiveis correlações.

Para os sedimentos de superficie de fundo, foi projetada uma rede de amostragem cobrindo desde as últimas evidências de pe netração de ăgua salgada no ẹstuārio, até uma pequena porção da plataforma adjacente (FIGURA 76). O limite de montante foi estabe lécido tanto por infumações verbais a respeito da penetração da ägua salgada, obtidas por mediçōes não sistemäticas de salinidade, como por observações de campo sobre a ocorrência de vegetação típica de ãguas salobras.

As amostras de ãgua foram coletadas em 12 estações, na prea mar e na baixa-mar, segundo a disposição mostrada pela FIGURA 76. Concomitantemente, foram coletadas amostras de superficie de fun do nas seções correspondentes às estações de amostragem de mate rial em suspensão.

A. Caracteristicas gerais da circulação regional de sedimen - tos

o estuário do Ttajaj-Açu desenvolve-se em planície costeira relativamente estreita, entre morros de rochas cristalinas. A par te mais interior dessa planicie apresenta terraços fluviais e ma rinhos, enquanto que sua porção litorânea é essencialmente consti tuida de sucessivas linhas de antigas praias, configurando um len çol de areias regressivas.

Nâo obtivemos dados altimétricos mais detalhados que nos permitissem avançar a intexpretaçäo. Entretanto, as observaçöes de campo e de fotos aēreas indicam evolução semelhante à dà Baixada 
Santista: é provävel que as partes mais interiores da planicie cos teira correspondam a um evento correlato da Formação Cananéia, en quanto que os cordões litorâneos contiguos devam representà a a regressão pos-flandriana.

A comparação de carta de fins do século passado, com cartas náuticas atuais mostra que o trecho final do estuário do ItajaI Açu teve suas caracteristicas naturais profundamente alteradas. As sim, o estuário terminava em um braço de meandro com desembocadura para $\mathrm{N}$, apoiado no prolongamento do morro do Hospital; desse meandro fazia parte o atual Saco da Fazenda (FIGURA 77). o pro longamento do morro do Hospital pode ser detectado pela laje que se situa próximo ao farol no 4 do molhe sul.

As principais alterações introduzidas nessa situação foram a construção de duas extensas linhas de molhes, uma norte e outra sul, truncando o antigo meandro (o que originou o Saco da Fazen da). Os molhes são levemente convergentes, e criaram uma nova saí da, artificial, para o estuário, voltada para E-NE.

Segundo o Plano Diretor Póxluăio do Brasil (1974), em 1914 "foram iniciadas as obxas de construção do porto. Em 1948 estavam concluj́dos $233 \mathrm{~m}$ do Cais Comercial, o terrapleno e um armazém. No vo trecho de $290 \mathrm{~m}$ e mais um armaizém foram concluídos em $1955 \mathrm{e}$, finalmente em 1959, encerraram-se as obras no trecho final de $200 \mathrm{~m} \ldots \cdot$.

Dessa forma, o estuārio do Itajaí-Açu adquiriu a conforma ção que hoje mostram suas margens ao final da década de 50 .

Alēm da conformação morfológica original da parte terminal do es tuáxio, podemos notar que os recortes da costa, na região de Itá jaí-Açu, mostram concavidade a sul, e crescimento das faixas sedí mentares para norte, evidenciando então transporte litorâneo $S-N$, segundo os critérios de SILVESTTER (1968, 1974).

Ora, um quadro genérico da variação sazonal de correntes cos teiras (FIGURA 78), mostra uma tendência geral N-S, inversa por tanto da acima apontada, exceto de março a maio.

Exame de fotos aéreas tomadas no mês de junho mostram níti do transporte rumo norte. Adicionalmente, examinamos transparên cias de todas as imagens da série LANDSAT disponiveis no CNRq/TNPE, e, atravēs da morfologia da pluma de sedimentos em suspensão asso 

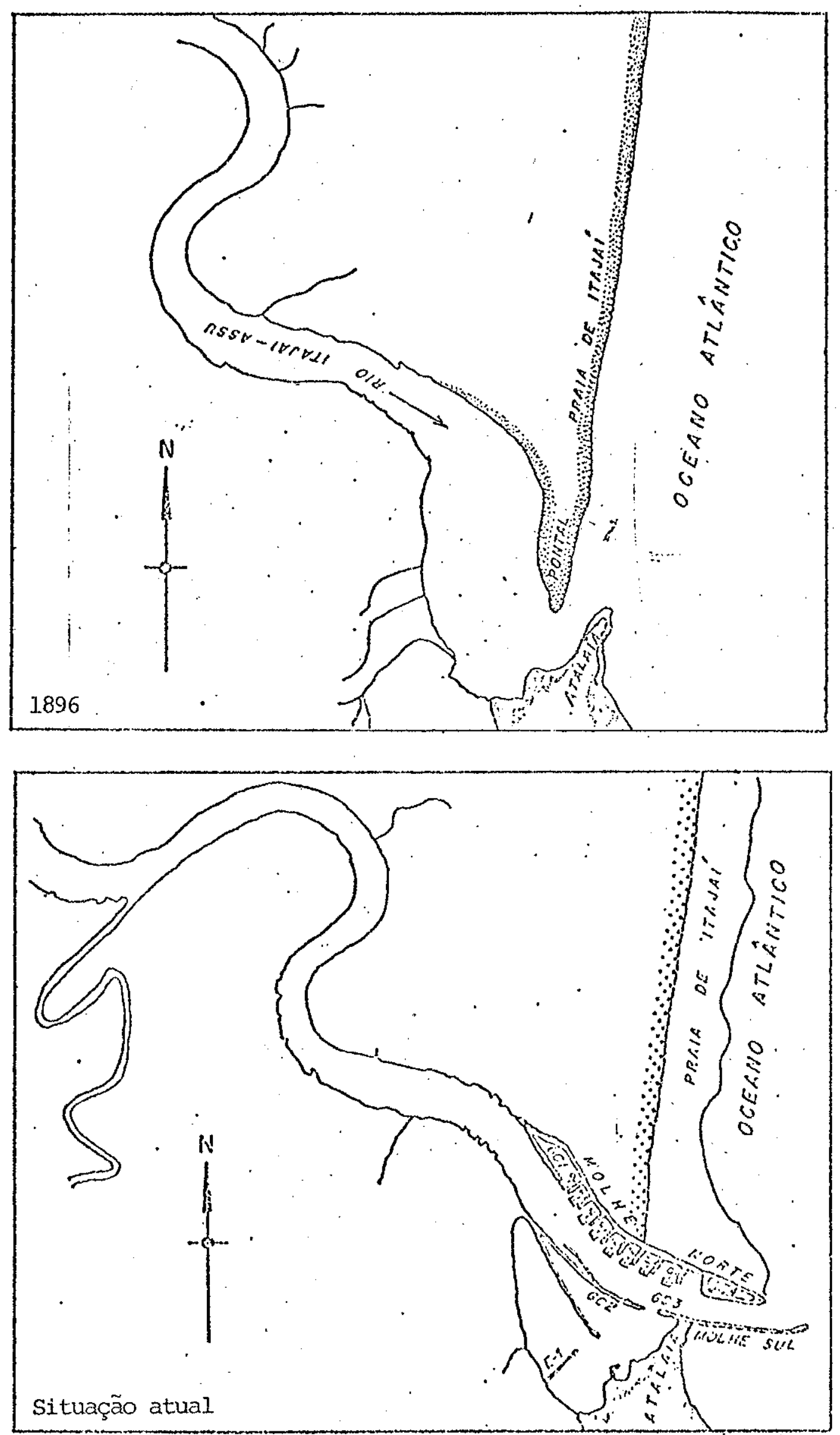

F̀IGURA 77 - Conformação da foz do Itajaí-Açu em 1896, e atual (VARGAS, 1983). 

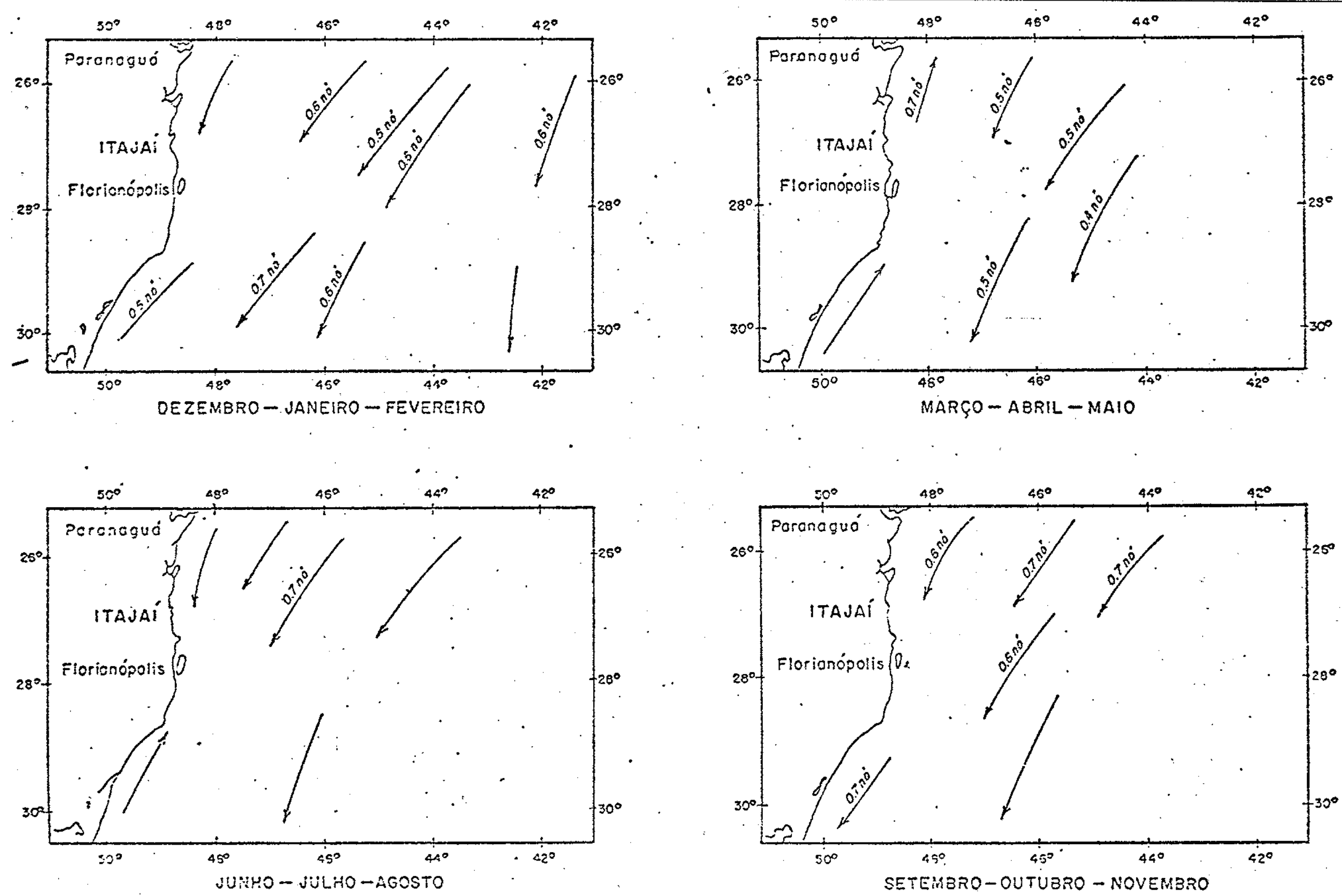

FIGURA $78^{\circ}$ - Variação sazonal das correntes costeiras na costa catarinense (Administração do Porto de Itajaí, sem dą ta). 
ciada à saída do Itajaí-Açu, pudemos inferir a seguinte situação:

$$
\begin{array}{ll}
06 / 04 / 1978 & \text { transporte } \mathrm{S}-\mathrm{N} \\
15 / 05 / 1975 & \text { transporte } \mathrm{S}-\mathrm{N} \\
13 / 06 / 1977 & \text { transporte } \mathrm{N}-\mathrm{S} \\
06 / 06 / 1980 & \text { transporte } \mathrm{N}-\mathrm{S} \\
15 / 07 / 1976 & \text { transporte } \mathrm{N}-\mathrm{S} \text { pouco acentuado } \\
18 / 08 / 1973 & \text { transporte } \mathrm{S}-\mathrm{N} \\
23 / 09 / 1973 & \text { transporte } \mathrm{S}-\mathrm{N}
\end{array}
$$

Para os meses restiantes não haviam imagens com visibilidade adequada, devido a cobertura de nuvens. Entretanto, admitindo que - transporte de material em suspensão, detectado nas imagens, te nha mesmo sentido que o de fundo, parece-nos correto admitir que, na maior parte do ano, as correntes costeiras dirijam-se para nor te, sendo esse o rumo predominante do transporte litorâneo.

por outro lado, segundo o Setor de Engenharia da Administra ção do porto de Itajaj. o volume de assoreamento no canal de acesso, calculado a partir de duas sondagens ecobatimétricas de fasadas de 1 ano, executadas pela Companhia Brasileira de Draga gem, è da ordem de $180000 \mathrm{~m}^{3}$. Até 1974, segundo o plano Diretor portuário do Brasil, a praticagem apontava pontos localizados de assoreamento no canal, por fuga de material do terraplerio, observando ainda que havia uma tendência à manutenção de cotas de $6,0 \mathrm{~m}$ no restante do canal.

A mesma fonte notava haver assoreamento da entrada da barra por estrangulamento, ocasionado por um banco de areia disposto pa ra SE, a partir da extremidade do molhe norte. Não obstante, o mencionado Plano Diretor Portuārio do Brasil afirma que o trans porte litorâneo predominante é dirigido para $\mathrm{N}$.

Assim, parece-nos importante, para efeito de melhor compreensão das contradições expostas na questão da movimentação dos se dimentos costeiros distinguir dois niveis de observação: um regio nal, comandado por fatores cuja causa não está ligada às caracteristicas da área em foco, e outro local.

Entre os fatores regionais, pođemos lembrar inicialmente a geração de ondas oceânicas provenientes da faixa de gexação māxima de ciclones situada no intervalo de latitudes $40^{\circ}-60^{\circ} \mathrm{S}$. São estas ondas as responsäveis pelas principais tendências de movimentação 
de sedimentos ao longo da costa (SILVESTER, 1974), e, embora não tenhamos obtido medidas de ondas para a região de Itajai-Açu, ob servações de ondas maj.s a sul são sugestivas de que as ondas oceâ nicas da ārea de interesse venham de sul e sudeste. Alëm disso, sabe-se que, pela força de Coriolis, a tendência de saída de águas de estuārios no hemisfério sul è para a esquerda, norte no caso do Itajaí-Açu.

os fatores locais poderão sofrer alguma variação do esquema imposto pelos fatores regionais, e estarão ligados à conformação da costa, descarga fluvial e prisma de marés.

Assim, a praticagem de ' Itajaí observa que hã uma tendên cia de saida de correntes para sul, a partir da barra do estuário. Isto talvez deva à concavidade da enseada nesse local, que po deria criar uma região de menores velocidades de correntes, para onde se dirigiria inicialmențe o fluxo estuaxino, antes de to mar rumo norte.

Esta possibilidade, e mais a inversão de corrente costeira que parece ocorrer em algumas epocas do ano, podem explicar a ob servação contida no plano Portuārio do Brasil de que há um engordamento de ambos os molhes do lado exierno, enquanto que o cresci mento do banco de areia que estrangula a entrada da barra se faz para sudeste.

Este ültimo fato, aparentemente contraditörio, prende-se à circulação local dos sedimentos, e será retomado quando da discus são da proveniência dos sedimentos de superficie de fundo.

B. Vazão fluvial e amostragem

Tendo em vista a premissa bäsica do presente trabalho, de que os sedimentos da superficie de fundo representam uma resultan te da dinâmica sedimentar, incluindo aí a cirrculação das ăguas , deve-se ponderar os resultados obtidos èm função de uma relação bảsica entre descarga fluvial e penetração da água do mar.

Com efeito, o avanço ou recuo da água salgada movimentada pe las marés no estuārio do Itajai-Açu, tem reflexos efetivos na se dimentação estuarina, dependendo esta ültima da relação entre dois fluxos básicos: os de correntes de maré, que adentram o estuärio e provocam barramento; e o fluvial, que a estes primeiros se contra põem. 
Dessa forma nos pareceu básico iniciar a análise pelo conhe cimento do regime sazonal do Itajaí-Açu. Alëm do reconhecimento, para o Itajai-Açu, de um período de "äguas altas", de julho a ou tubro, e um periodo de "āguas baixas", de dezembro a maio, não identificamos nenhum trabalho que caracterizasse os dados hidro gräficos da ärea de interesse.

Atendendo a nossa solicitação, o 29 Distrito do DNAEE, se diado em Curitiba, enviou dados de vazão de Itajaí-Açu e do '. Itą jaî-Mirim, referentes a una série de 44 anos, de 1935 a 1978.

As estações de observação foram escolhidas imediatamente a montante da ültima estação em que se detecta alguma variação. de nível d'ägua fluvial por barramento da maré;. são elas as estações de Indaial e Brusque.

Para essas duas estações foram calculadas as mēdias mensais de vazão, bem como seus desvios-padrões. Adicionalmente é apresen tado um coeficiente de variação que é a razão entre desvio-padrão e mëdia: quanto mais se aproxima da unidade, menos as médias são representativas.

No caso do Itajai-Açu, os principais resultados obtidos acham-se apresentados nas FIGURAS $79 \mathrm{e} 80$.

o Itajaí-Açu apresenta dois máximos e dois mínimos de vazão. os desvios-padrões das médias mensais são elevados, aproximando-se da média no mês de agosto. Isto mostra um regime em que a uma certa regularidade sazonal, impõem-se episódios de grandes descar gas. Não é o intuito desta anālise chegar às causas das variações de vazão desse rio; entretanto, pela situação da bacia do Itajai-Açu, é possivel que chuvas orográficas, sazonalmente associadas à chegada de frentes polares, possam causar räpidas cheias. Nesse sentido, deve-se considerar que o coeficiente de variação do mês de agosto, próximo da unidade, sugere que as variações de médias mensais desse mês estejam associadas a uma oscilação da época de chegada de frentes de primavera, responsāveis, provavelmente,pelo nitido máximo assinalado entre setembro e outubro.

A partir desses dados, esperava-se que a amostragem efetuada na primeira campanha de sedimentos da superficie de fundo,ter-se-ia situado em período de cheia do rio, quando, estatisticamen te, a vazão do rio teria superado a marca das médias do máximo se 


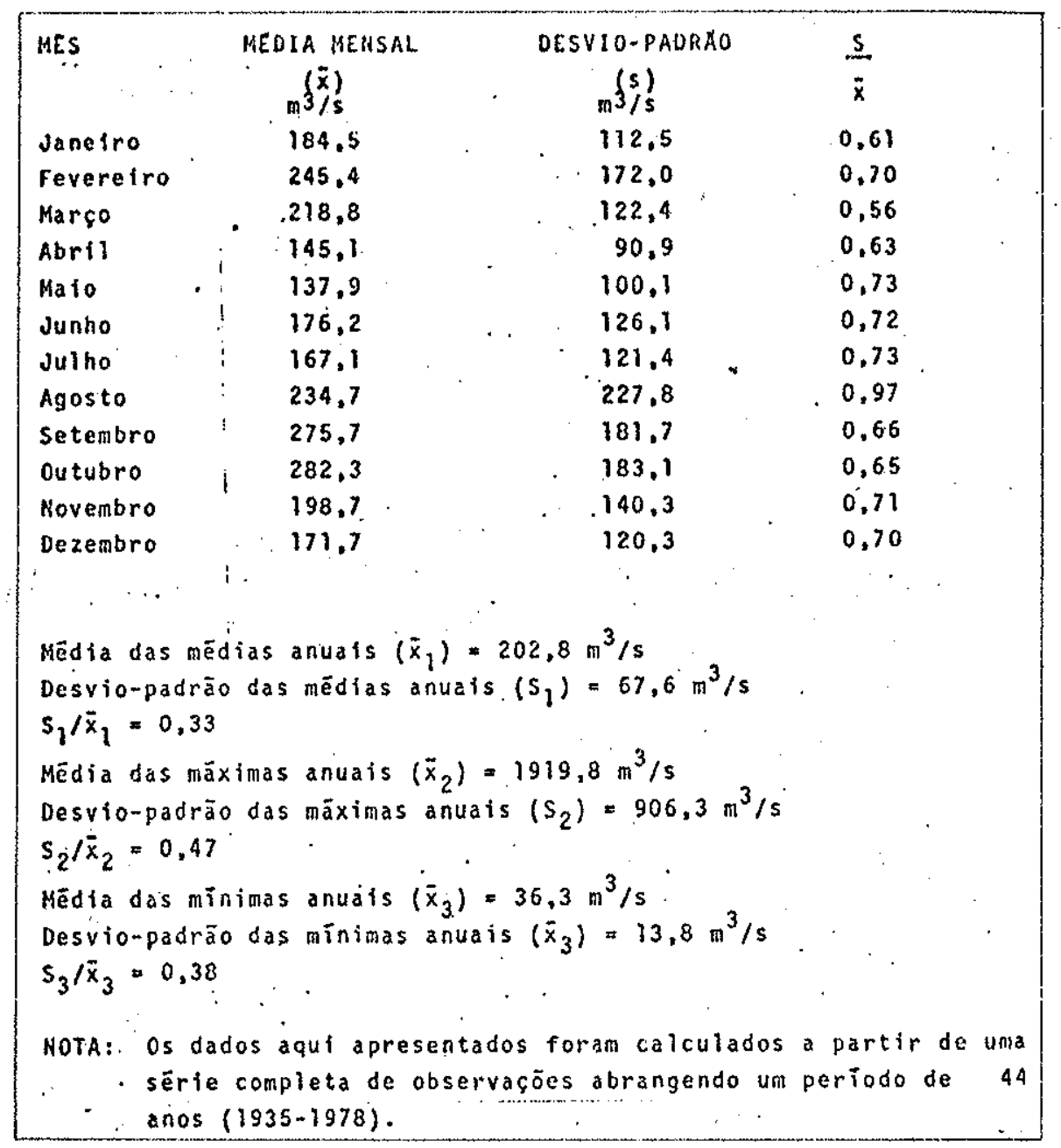

EIGURA 79 - Principais características de descarga do rio Itajai-Āçu, na es tação de Indaial.

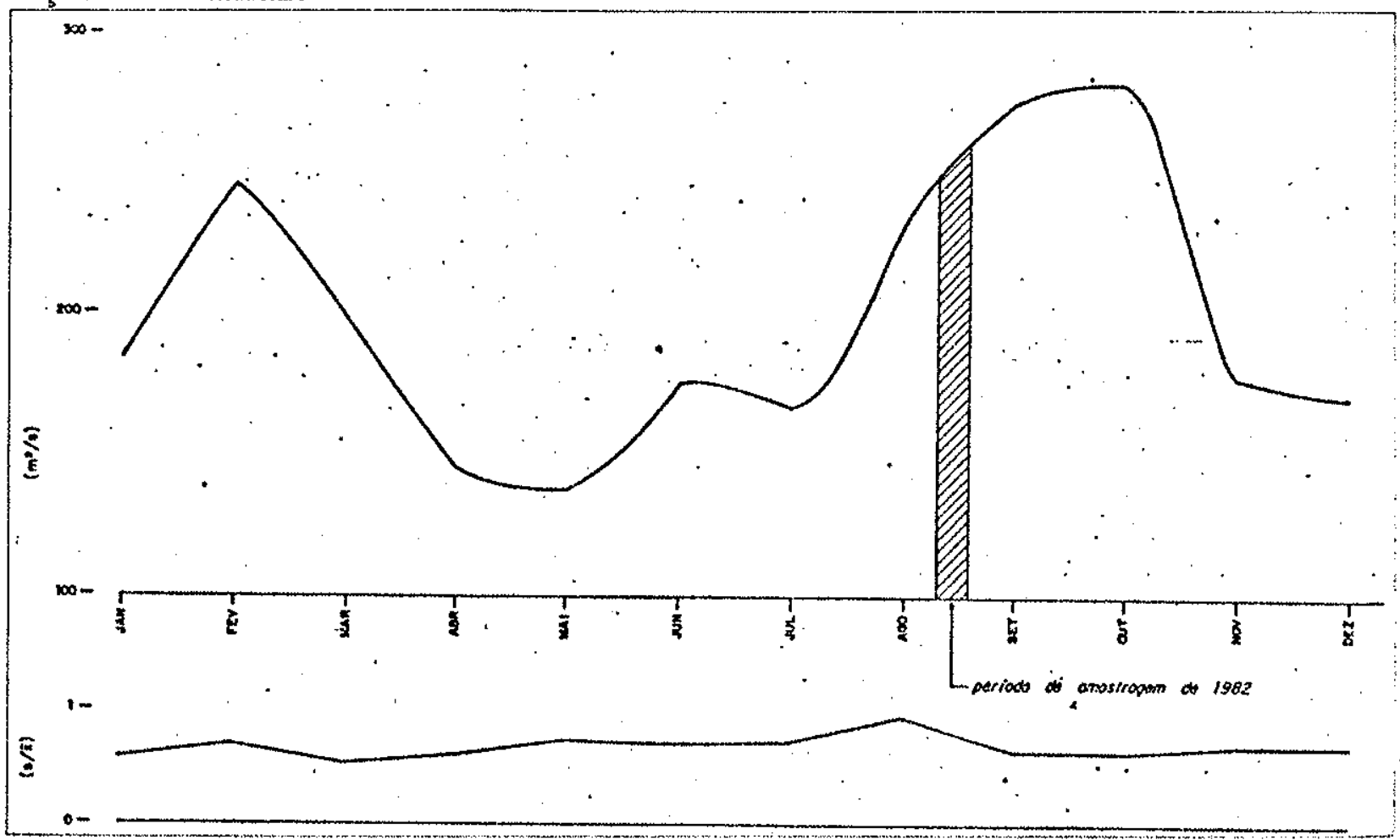

FIGURA 80 - Representação gräfica dos dados de descarga do rio Itajai - Açu (mëdias mensais de 1935 a 1978), na estação de Indaial. 
cundário, que ocorrem em fevereiro.

Assim, essas amostras corresponderiam a um periodo em que a descarga fluvial ia adquirindo sua força mäxima conträria à pene tração das marēs, não sendo representativa da fase de maior des carga fluvial, que só ocorreria entre setembro e outubro.

No entanto, é préciso considerar que, das variações observa das nas médias mensais, especialmente no mês de agosto, a asserti va feita anteriormente deve sex tomada com ressalyas. O significa do da amostragem de 1982 só pôde ser analisado de modo mais real apōs a obtenção dos dados específicos referentes a 1982, já em 1983 (FIGURA 81).

Uma revisão e avaliação qualitativa dos dados de vazão do Itajaí-Açu, realizada em 1983 no 2o Distritó do DNAEE em Curiti ba foi fortemente sugestiva de que se possa provavelmente vix a definir dois comportamentos básicos para o rio: em períodos de pluviosidade moderada, a distribuição de vazão segue aproximadamen te o padrão da curva média da FIGURA 82. Porēm, em anos excepcionalmente chuvosos, ocorrem máximas de inverno, sempre mais eleva das que as máximas de verão.

Ora, os dados então disponiveis, referentes a 1983, indica vam ser esse um ano de altas vazões, ou seja, excepcionalmente chuvoso, de tal sorte que o período de águas altas de inverno de veria ser mais pronunciado.

Essa previsão confirmou-se, aliás de modo catastrófico, con forme pode-se verificar na FIGURA 82.

Os dados de coeficiente dé variação (FIGURA 82) são sugesti vos de grande irregularidade de vazões de julho a setembro, me lhorando em outubro e novembro.

Pela FIGURA 82 verifica-se que a vazão do rio, no momento da coleta dos sedimentos de superfície de fundo (final de junho - ini cio de julho) estava em torno de $700 \mathrm{~m}^{3} / \mathrm{s}$, pelo segundo mês conse cutivo (mëdia de maio $=766,05 \mathrm{~m}^{3} / \mathrm{s}$ ), valores comparäveis ao pe riodo de maior vazão de 1982 (FIGURA 81).

Dessa forma, acredita-se que os sedimentos então coletados reflitam as fácies de superficie de fundo do estuāxio já adaptado a condições de águas altas, porēm não excepcionais (que correspon deriam à situação imediatamente seguintes às cheias excepcionais 


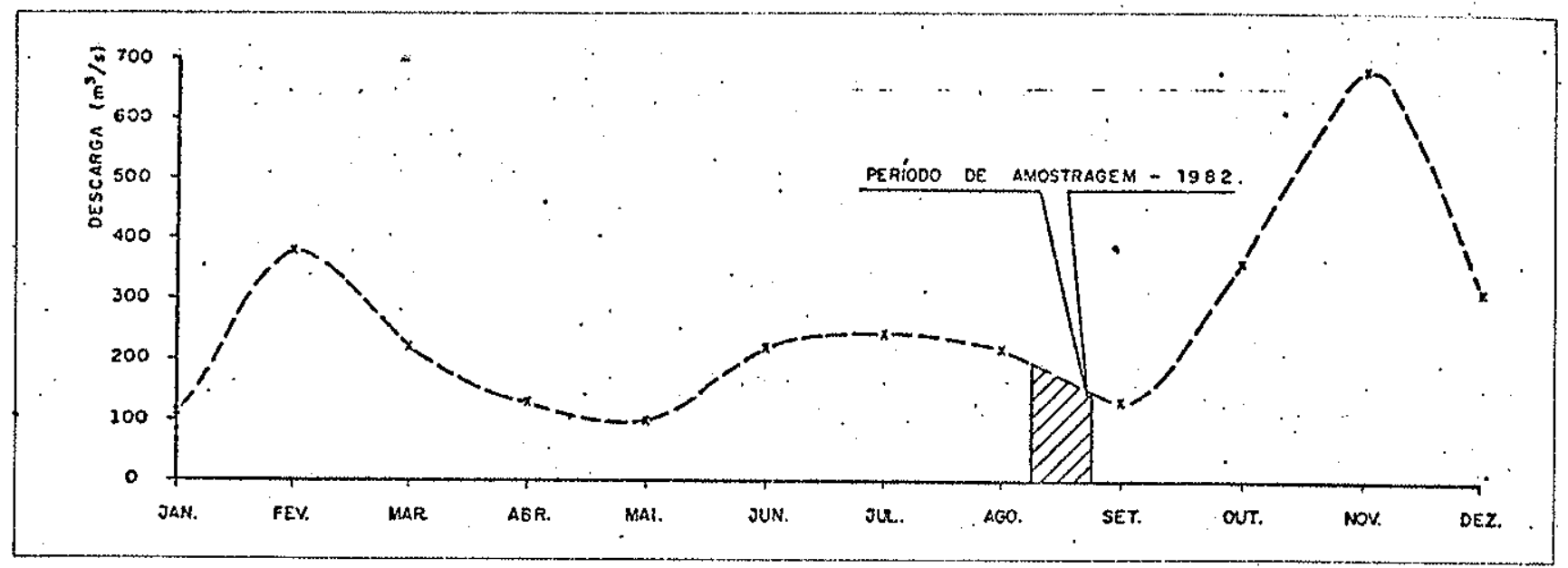

FIGURA 81 - Representação gräfica dos dados de descarga do rio Itajaí-Açu, na estação de Indaial, no ano de 1982.

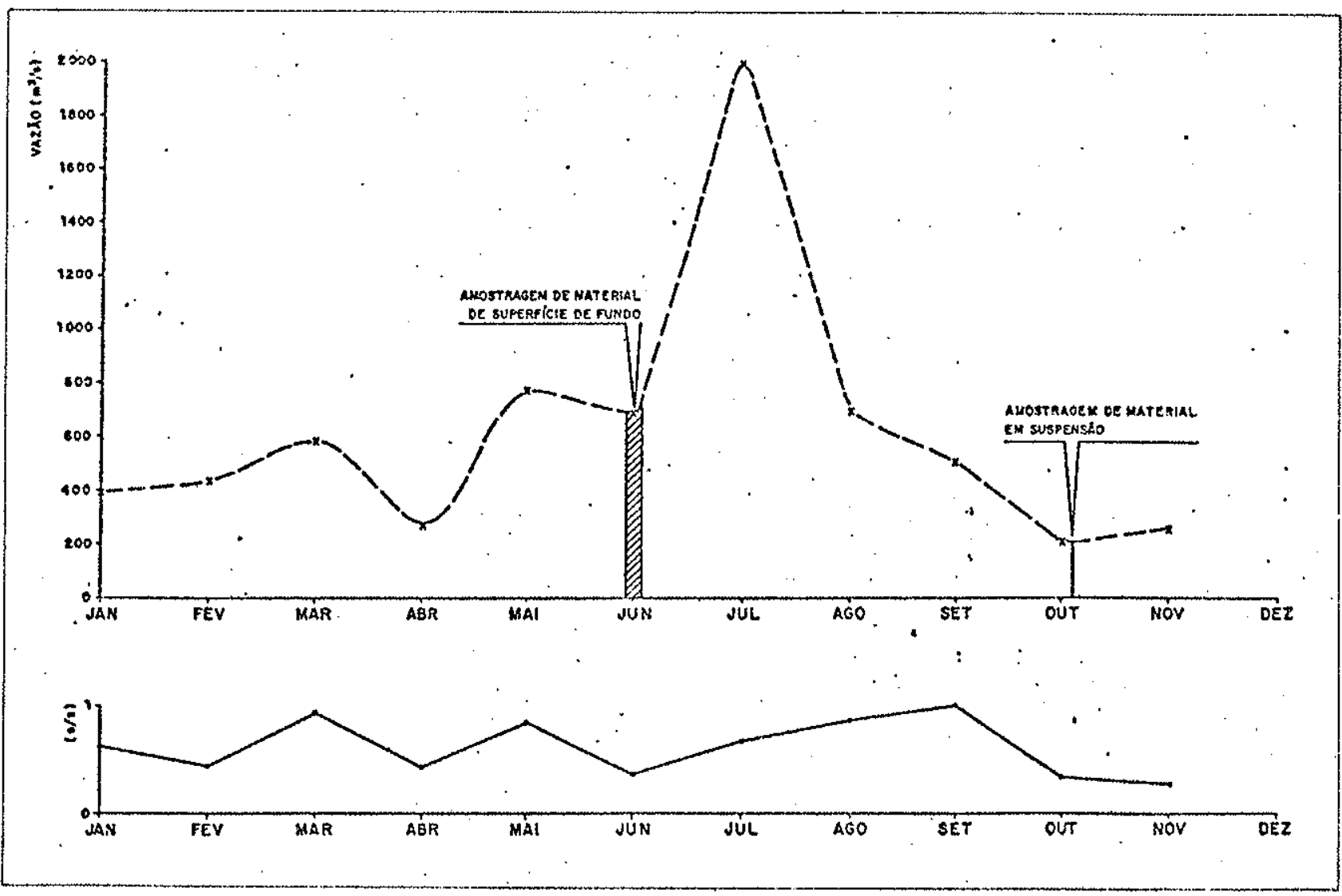

FIGURA 82. - Representação gráfica de dados de descarga do rio Itajaí-Açu , estação de Indaial, para o ano de 1983. 
do mês de julhol.

Por outro ládo, o material em suspensão foi coletado em 5 e 6 de outubro, ocasião em que o rio apresentava, pela curva de 1983 (FIGURA L vazões em tomno de $300 \mathrm{~m}^{3} / \mathrm{s}$.

Mais precisamente, a partir de dados diārios de vazão, sa be-se que a vazão do Itajaí-Açu na estação de Indaial era de $288,5 \mathrm{~m}^{3} / \mathrm{s}$ dia 5 e $240 \mathrm{~m}^{3} / \mathrm{s}$ dia 6 de outubro.

Esses valores aproxima-se daqueles que ocorreram durante a campanha de 1982 .

Em sintese, em termos da vazão do rio, pode-se dizer que a campanha de 1983 processou-se sob condições comparáveis às das va zões mëdias máximas e mínimas de 1982.

Em decorrência, e de modo bastante simplificado, pode-se es timar que o conjunto de dados obtidos nas campanhas de 1982 e de 1983 podem ser projetados para situações de descarga significativas, realizäveịs em um ünico ano.

C. Variações recentes da morfologia do fundo do estuário

Realizamos uma comparação entre as edições existentes da carta DHN 1801, com o objetivo de observar as tendências evolutivas da morfologia subaquātica na área de interesse do estuário do Itajaí-Açu.

As cartas comparadas, ambas na escala 1:15 000, correspondem a:

- 1a. edição, publicada em 13/12/1936, levantamento de 1935, com pequenas correções no período de 1937 a 1949 , correta até $30 / 09 / 1955$.

- 2a. edição, publicada em 11/06/1957, levantamento de 1956, com pequenas correções no períođo de 1958 a 1980 , correta até $30 / 06 / 82$.

A comparação tem caräter mormente qualitativo e é apresenta da nas FIGURAS 83 e 84 , destacando-se as mudańças que seguem.

$\mathrm{Na}$ região litorânea observa-se na carta da edição mais mo derna, ampliação da ārea de profundidades menores que $5 \mathrm{~m}$ ( ou seja, hā engordamentọol a norte e a sul dos molhes de proteção da barra. 


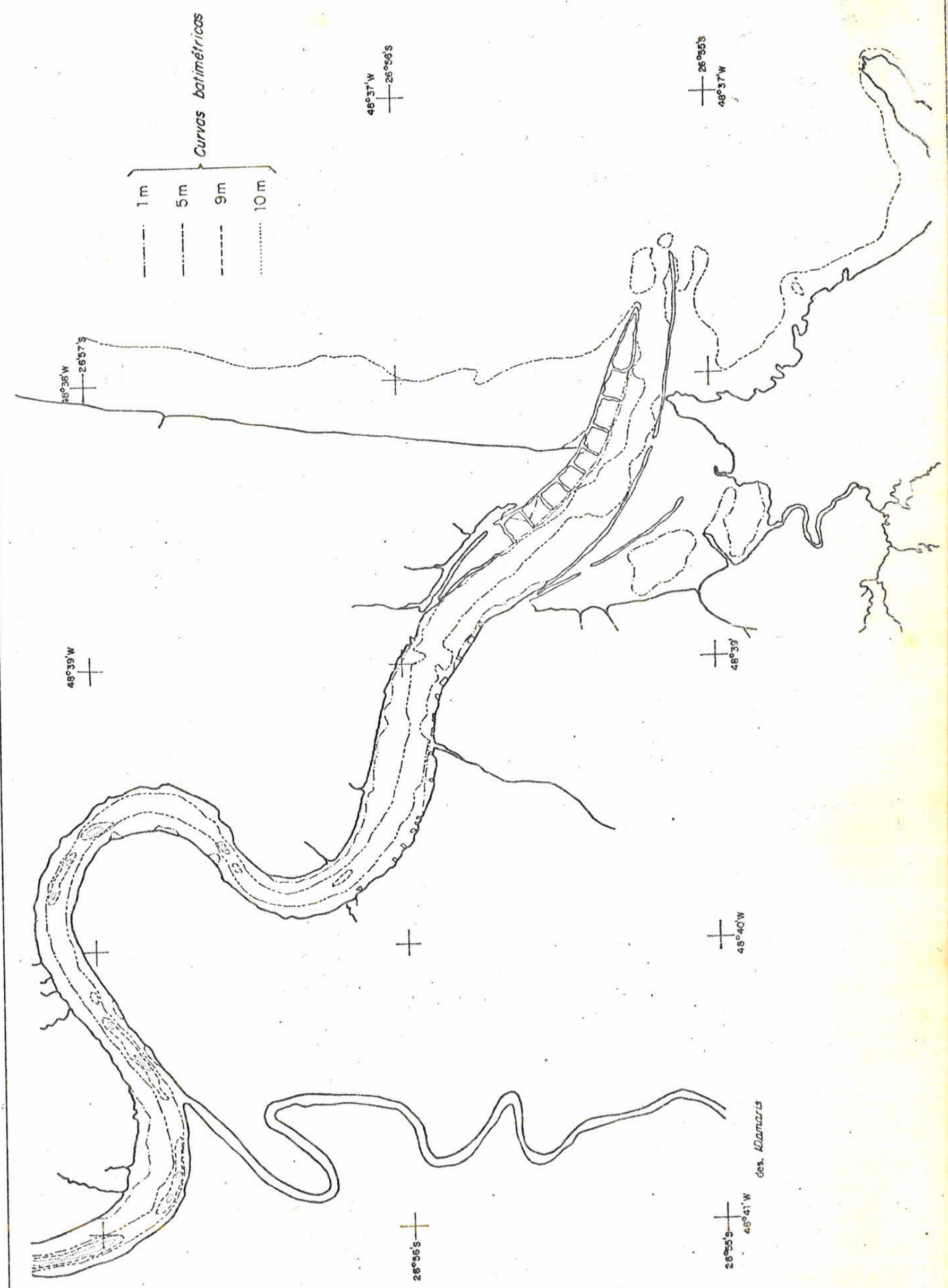

FIGURA 83 - Esboço da 1a edição da Carta DiN 1801 (1935). Notar áreas com Fwäu didades maiores que $9 \mathrm{~m}$, na porção mais a montante do estuário. 


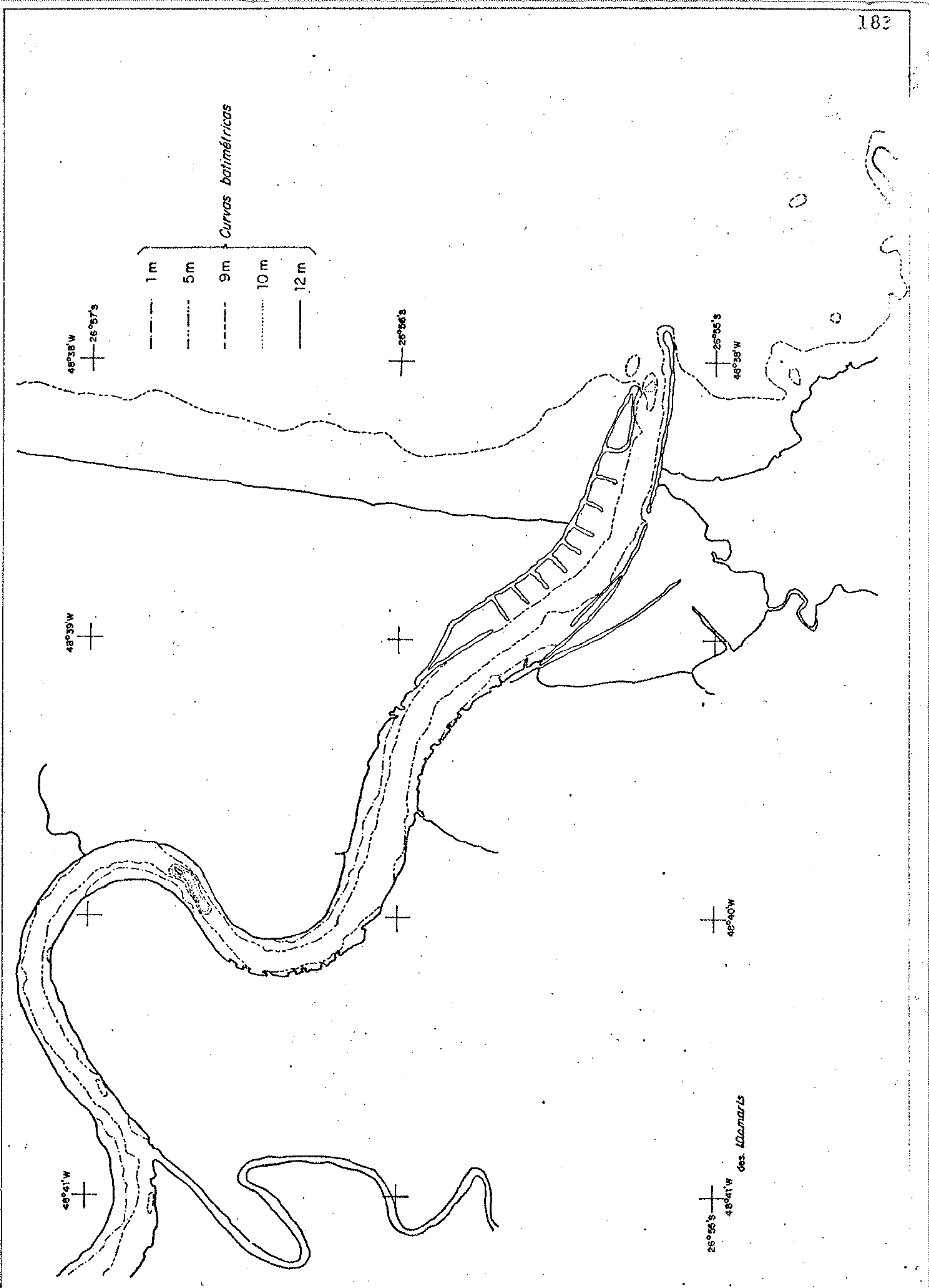

FIGURA 84 - Esboço da 2a edição da Carta DHN 1801 (1956). Notar comparativamen te à la edição, redução de profundidades mais a montante e aumento junto à barra. 
A norte do molhe norte o contorno da isöbata de $5 \mathrm{~m}$ mantēm- se paralelo ao traçado antigo, apenas deslocando-se em direção ao mar aberto. Por outro lado, o sul do molhe sul, na edição mais antiga, a isóbata - $5 \mathrm{~m}$ apresenta uma reentrância até bem próximo da linha de costa, com profundidades mais ao largo em torno de 6 m. Na edição mais recente da carta 1801, esta mesma curva mos tra-se retificada, sugerindo acreção de material de fundo neste local.

O restante do contorno da curva de - $5 \mathrm{~m}$, nas demais áreas litorâneas é muito semelhante, senão coincidente, em ambas as edi ções da carta 1801.

Situação semelhante é observada no contorno da isóbata - $10 \mathrm{~m}$, que embora não seja o mesmo nas cartas das duas edições, situa-se aproximadamente à mesma distância da costa. As diferenças no con torno desta última curva devem-se provavelmente à maior densidade de observações do levantamento efetuado para a carta da segunda edição.

No interior do estuário, a montante do banco da margem es querda, situado em frente ao porto, observa-se nas duas cartas, que as formas do canal, bem como ạ dos bancos situados nas mar gens convexas permanecem as mesmas em ambas as cartas. Por outro lado, as profundidades do canal principal são sempre maiores na versão mais antiga da carta DHN 1801. Esta situação é evidenciada pela diminuição das áreas abrangidas pelas curvas de - $9 \mathrm{~m}$ e - 10 m traçadas nas FIGURAs 83 e.84.

$\mathrm{Na}$ área terminal do estuário, que compreende a bacia de evo lução e canal de acesso, observa-se tambēm uma certa manutenção da forma do canal de maiores profundidades, embora na carta mais an tiga a largura desta faixa de maiores profundidades seja menor.

Ainda na área terminal do estuário observam-se na carta da segunda edição, profundidades ligeiramente maiores, sobretudo na barra e bacia de evolução. Estas mudanças devem refletir as su cessivas remoções de material de fundo por dragagem, desenvolvidas mais recentemente.

Exemplos desta situação ocorrem no banco da márgem esquerda, situado em frente ao cais, que se apresenta bem menor na carta mais recente, e também no banco arenoso da barra, quase inexisten 
te na carta da $2 a$. edição.

As observações sobre as variações de profundidades a partir das duas ediçõés da carta 1801 da DHN, embora devam ser tomadas como avaliações qualitativas, sugerem como modificação mais signi ficativa a redução generalizada de profundidades no setor do in terior do estuário situado a montante do cais e nas áreas litorâa neas situadas imediatamente a norte e sul dos molhes protetores da barra do Itajaî-Açu.

As modificações observadas na porção terminal do estuário, compreendendo a bacia de evolução e canal de acesso, foram ocasio nadas por dragagem.

No restante e de maneira mais geral, verifica-se uma forte tendência à manutenção da forma e deposição do canal de maiores. profundidades no interior do estuário, bem como a manutenção da morfologia subaquática em toda a área ljtorânea mais afastada da barra.

D. Caracteristicas dos sedimentos de superfície de fundo

1. Resultados obtidos na cámpanha de 1982

a) Observações realizadas durante a amostragem

Durante a campanhá de amostragem na área de interesse foram realizadas, simultaneamente à coleta, descrições täctil-visuais sobre as características dos sedimentos recolhidos. Dentre as informações destacam-se a composição granulométrica estima da, consistência, presença de restos vegetais, estruturas se dimentares, coloração, e presença de restos de organismos e/ ou organismos vivos.

A sistematização dessas informações para o conjunto das amostras recolhidas na área de interesse, permitiu a elaboração do mapa da FIGURA 85, cujos elementos principais são descrí. tos a seguir.

Na porção superior do estuário, a montantie do perfil das amos tras 72-73-74, observam-se sedimentos de composição mista ar gilosa e arenosa com colorações castanha a amarronzada em su perfície passando gradualmente em direção à base para colora ção cinza mais escura. As cores castanha e marrom indicam pro veniência fluvial de aporte terrígeno; que gradualmente vai 


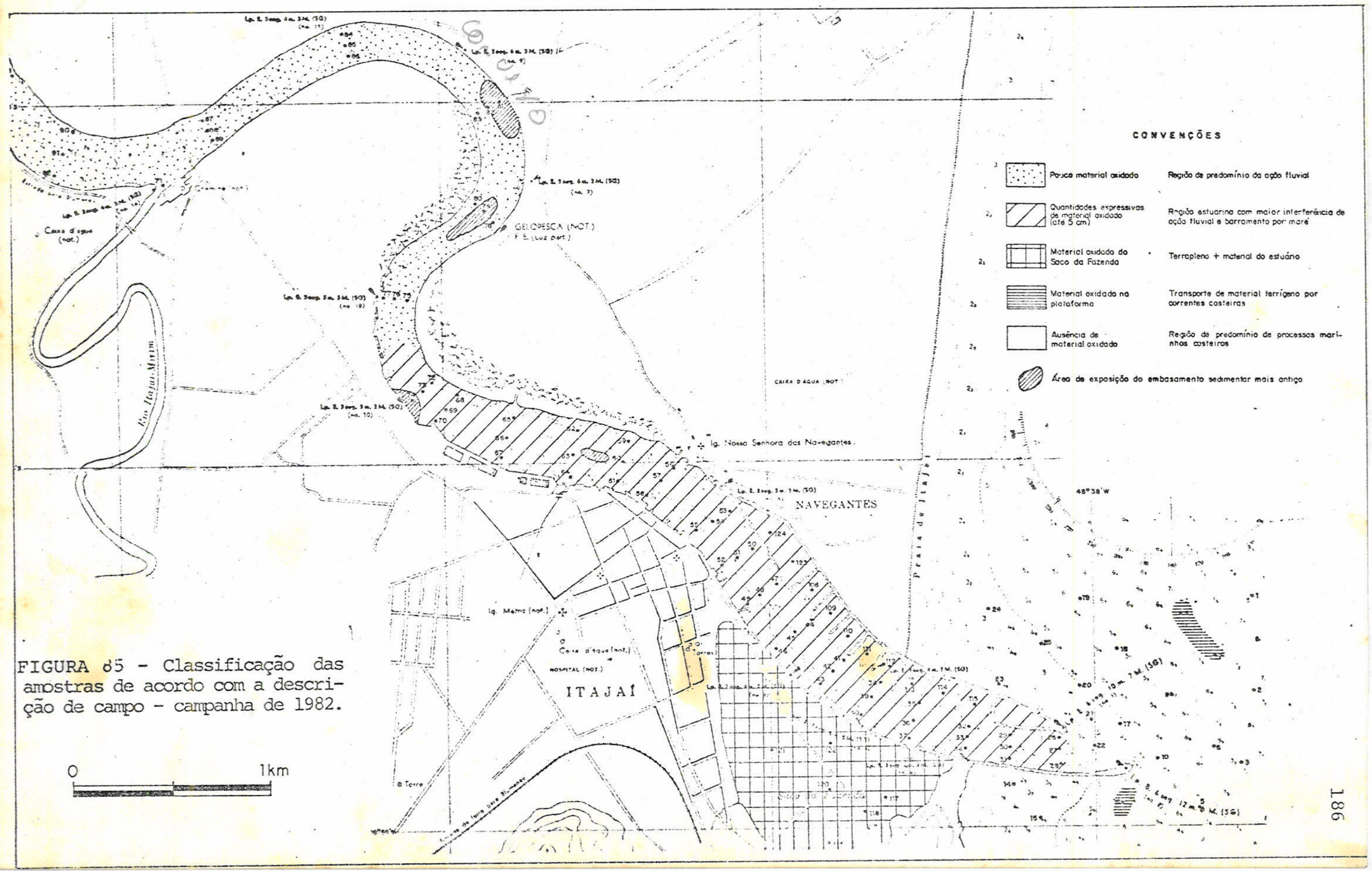


se adaptando às condições mais redutoras da parte cinza das amostras.

As porções de sedimentos mais arenosos distribuem-se em faixas alongadas e estreitas, sobretudo nas margens convexas, tendo um desenvolvimento semelhante às barras de meandro dos canais tipicamente fluviais, quer se considere à porção do Itajaí-Açu em que jā começa a prevalecer urn regime mais fluvial (a montan te dà seção 72-73-74), quer na região jä tipicamente estuarina, como é o caso do banco arenoso situado à altura da bacia de evolução, defronte ao cais da PORTOBRAss.

Ainda a montante da seção 72-73-74 concentram-se as áreas de exposição do embasamento sedimentar mais antigo, atestadas pe la presença de sedimentos mais consistentes, frequlentemente a presentando restos de corchas e/ou presença de "seixos" de material argiloso mais coeso, misturado em areias mais grossas ( amostra 82). Essas áreas de exposição do embasamento mais an tigo encontram-se preferencialmente junto às margens côncavas, que apresentam na porção emersa feições de erosão intensa, co mo solapamento e desbarrancamento de margens, como por exemplo, à alturà da estação 81 .

Nesses locais o embasamento sedimentar mais antigo encontra-se praticamente em erosão, sendo que algumas vezes (ponto 74) o amostrador recupera apenas fragmentos do substrato, cobertos por película milimétrica de material argiloso oxidado.

A jusante do perfil das amostras 72-73-74 até a barra, ocorrem sedimentos tanto de composição arenosa como argilosa, apresentando coloração amarronzada característica de material oxidado, sempre recobrindo material de mesma granulometria e coloração cinza escura. Neste setor, especialmente nas proximidades das amostras 68-69-70, observou-se um espessamento da porção supe rior de material oxidado que atinge espessuras de 5 a $6 \mathrm{~cm}$, indicando uma deposição mais intensa deste tipo de material.

Levando em conta que a coloração amarronzada é característica de material terrígeno, oxidado, de aporte fluvial, pode-se supor que é neste setor que se processa com maior intensidade - efeito do barramento por marés, ocasionando a decantação de sedimentos. 
No Saco da Eazenda observam--se amostras de composição mais fi na, exclusivamente silto-argilosas, onde a coloraçäo amarron\%a da é dominante, sugestiva de deposição, tanto de material oxi.dado carreado pelo estuário, como da remobilização de material. de terraplenagem das margens.

Ainda na porção terminal do estuário, junto aos pontos 29 e 32, obrervaram-se amostras de composição argilosa na base e are nosa no topo, constituindo duas, fases distintas. Assim, a por ção arenosa é exclusivamente arenosa e se sobrepöe, por conta to brusco, ao material argiloso basal. Esta situação deve cor responder ao avanço de areias marinhas, transportadas por ar raste em direçäo do interjor do estuärio.

A regiäo fora da barra é caracterizada por duas áreas de sedi-. mentos de diferentes composições, arenosas e argilo-siltosas, bem djFerenciadas, näo se observando, à execução das amostras 7,8 e 16, a presença de material oxidado. Junto às praias e à saida norte do estuärio predomina material axenoso, quase sem argilas, do coloraçäo cinza clara. No restante pxedominam si. tes e argilas de coloração cinza escura, sem a presença de ma terjal oxidado. Apenas nos pontos 7,8 e 16 obsexvou-se pequena película de material acastanhado, indicando contribuição fluvial para o próprio material txansportado pelas correntes costeiras mais pröximas.

b) Classificação textural.

A distribuição faciológica apresentada na FIGURA 86 foi feita segundo a classificação textural do diagrama trianguiar de SHEPARD (1954, in SUGUIO, 1973).

Esta classificação, não obstante ser necessariamente numérica, tem a vantagem de dar uma descrição mais facilmente perceptí vel do sedimento, já que se aproximabastante de sua descri ção tāctil-visual.

Ela indica, para a ärea da plataforma a $\mathrm{N}$ da saía do estuärio, uma gradação de areias atē argilas. Estas ültimas configuram uma mancha de limite grosso modo $\mathrm{N}-\mathrm{S}$, enquanto que as areias adentram o estuário, contornando o molhe N. Os siltes, por sua vez, delimitam una clara zona de influência na parte sul da porção final do estuário e ocupam uma expressiva porção da pla 


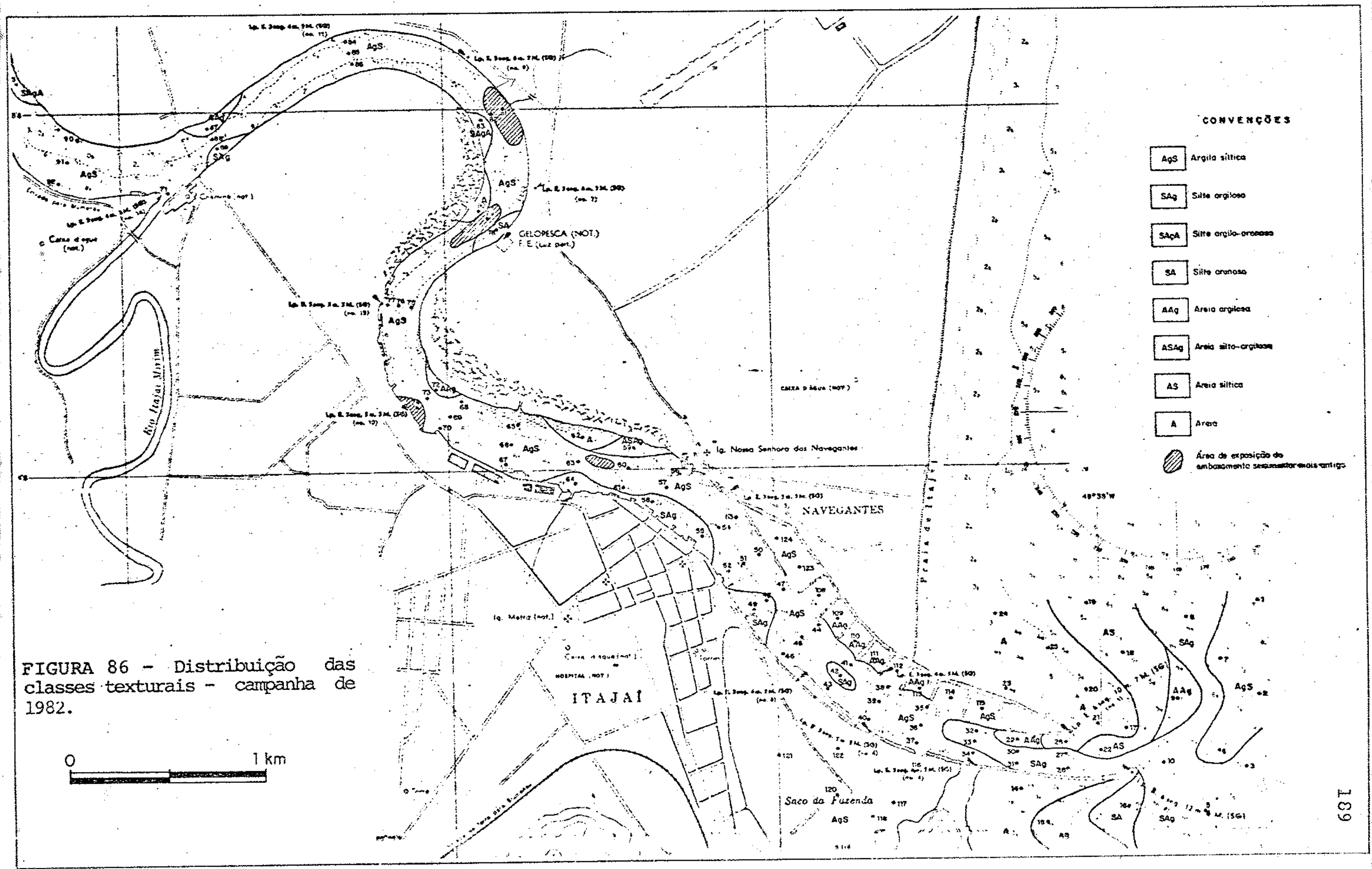


taforma a sul da desembocadura do estuário, após o que se sepa ram das areias próximas à região praial.

Essa distribuição sugere um transporte $\mathrm{N}-\mathrm{S}$, que carreia sedi mentos arenosos para dentro do estuário até após a altura da amostra 29, com influência reduzida na altura da amostra 32 (silte argilo-arenoso): Indica também que a parte terminal do estuário é claramente dividida em duas porções longitudinais, predominando siltes na metade sul, que se estendem à plátaforma.

Dessa maneira, a circulação de sedimentos na porção terminal do estuário é indicativa de um esquema bem definido de entrada de material grosso em faixa que perlonga o molhe norte, e saida de material fino a sul dessa faixa. Naturalmente, não se pode excluir que haja entrada de siltes da plataforma estuário aden tro, de tal sorte que a lingua de siltes que se estende após as amostras 32 e 33 representam, em conjunto com as areias, um limite de avanço da ãgua salina por ocasião das preamares.

o restante da área estudada do estuário, bem como o Saco da ra zenda, até a bacia de evolução, revela uma predominância de ax gilas siltosas, com algumas exceções, a seguir discutidas.

Um banco arenoso delineia-se na altura das amostras 59 e 62 . Le vando em conta observações de campo efetuadas a montante da bạ cia de evolução, jā na porção fluvial do Itajaí-Açu, que reve laram forte corrente e erosão acentuada nas concavidades de meanđros, parece mais provável relacionar o crescimento desse banco ao aporte fluvial, e não da derivação do material arenoso da plataforma.

Defronte a esse banco arenoso, e apoiando-se no final do cais da PORTOBRAS, define-se uma manicha siltosa mais ou menos conti nua. E possivel que essa mancha, bem como aquela definida em torno das amostras 48 e 49 sejam em parte originadas por fuga de material do terrapleno. Esta questão jā havia sido apontada no Plano Hiaroviārio Nacional, e, se tiver somente essa ori gem, deverá ser resolvida com a consolidação das obras. que atualmente se desenvolvem no cais.

Já os sedimentos arenosos entre os espições das amoṣtras 109. 110,111 e 113 acham-se bastante próximos da frente de penetra- 
tração do material arenoso da plataforma. Observações de cam po mostraram ainda acúmulo de areia na pọção NE da ārea entre os espigões da amostra 114. Assim, a tendência de penetração de areia da plataforma ao longo do molhe $\mathrm{N}$ pode ser retraçada estuário adentro até a altura do espigão que se situa entre as amostras 108 e 109 .

c) Diâmetro mēaio

A distribuição dos diâmetros médios difere da classificação textural de SHEPARD, pois descreve uma tendência estatisticamente obtida, buscando uniformizar inclusive populações de da dos com distribuição não normal (bimodais, por exemplo).

o padrão obtido, representado na FIGURA 87, mostra uma distri. buição faciolögica bastante concordante com a obtida através da classificação de SHEPARD.

Assim, na região da plataforma tem-se, da costa para E, passa gem de areias para siltes (estes com diversas gradações), con figurando mais nitidamente o padrão de transporte $\mathrm{N}$-S anterior mente sugerido. A $N$ do molhe norte, e adentrando o estuário até pouco após a amostra 26, tem-se uma mancha de areias finas, que são os sedimentos de granulação majs grossa detectados em toda a ärea de estudo. Esta mancha de areia fina deve corres ponder à porção final de um banco de areia, provavelmente enrí quecido com areias mais grossas provenientes da zona de arrebentação próxirna do molhe norte.

Neste mapa, a zona principal de penetração de sedimentos pelo avanço da ăgua salina pode ser delineada atē pouco ápōs a amostra 32, por meio de uma faixa de areias finas, siltes gros sos é siltes médios. A métade sul da porção final do estuário é dominada por sedimentos mais finos (siltes finos e siltes mui to finos). Esta situação no conjunto ë similar à indicada no mapa prévio.

Cabe aqui retomar a questão do banco arenoso, apresentada ao final da exposição dedicada à circulação regional de sedimen tos, para destacar que essa feição sedimentar sofre influência de fatores de ordem regional e local. Do ponto de vista regio nal, o banco deve crescer por adição de material proveniente da deriva litorânea predominante sul-norte, com alguma reversão 


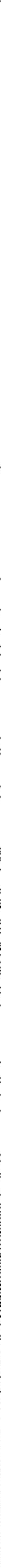


d) Assimetria

Do ponto de vista dinâmico, interpretamos, por hipótese, äreas carac terizadas por assimetrias negativas como sendo sujeitas a um processo de lavagem, o que explicaria a tendência à remoção de seus componentes mais finos. As áfeas de assimetria positiva indicariam regiões em que há certa tendência à deposição, por algum tipo de barramento ou interferência dos agentes de trans porte.

Na ārea estudada, a partir da distribuição da assimetria (FIGU RA 88) podem ser constatadas, segundo os critéxios anteriormen mente expostos, as seguintes zonas principais de movimentação:

$\mathrm{Na}$ plataforma, uma faixa aproximadamente $\mathrm{N}-\mathrm{S}$, com inflexão pă ra a ponta do molhe sul. Esta faixa deve representar a zona de mais intensa movimentação local.

Imediatamente a $\mathrm{N}$ do molhe norte, contornando-o em dixeção do estuário, coloca-se uma mancha de sedimentos com assimetria ne gativa. Esta mostraria que, no processo de carreamento de areia đa plataforma dentro do estuário, jā evidenciado pela anälise. dos mapas precedentes, uma ação mais enērgjica da penetração da corrente se verifica até pouco alëm da amostra 29. Esta situação serve de elemento de suporte para a determinação do limite mais efetivo de arraste provocado pela penetração de ägua mari nha.

No interior do estuário, até o final da bacia de evolução, no ta-se um predomínio de assimetxias negativas, que se estende em direção à barra até após as amostras 30 e 31 . Considerando que a montante da bacia de evolução o regime estuarino cede passo rapidamente a um regime fluvial ( de contínua remoção de finos por lavagem), pode-se interpretar essa predominância de assimetrias negativas como indicativa de capacidade do sistema estuarino em promover a remoção barra afora dos sedimentos mais finos. Esta situação é sugestiva de um predomínio da descarga fluvial no balanço resultante da interferência rio-correntes de maré.

Das regiões de domínio de sedimentos de assimetria positiva des taca-se a faixa da plataforma orientada aproximadamente norte- 


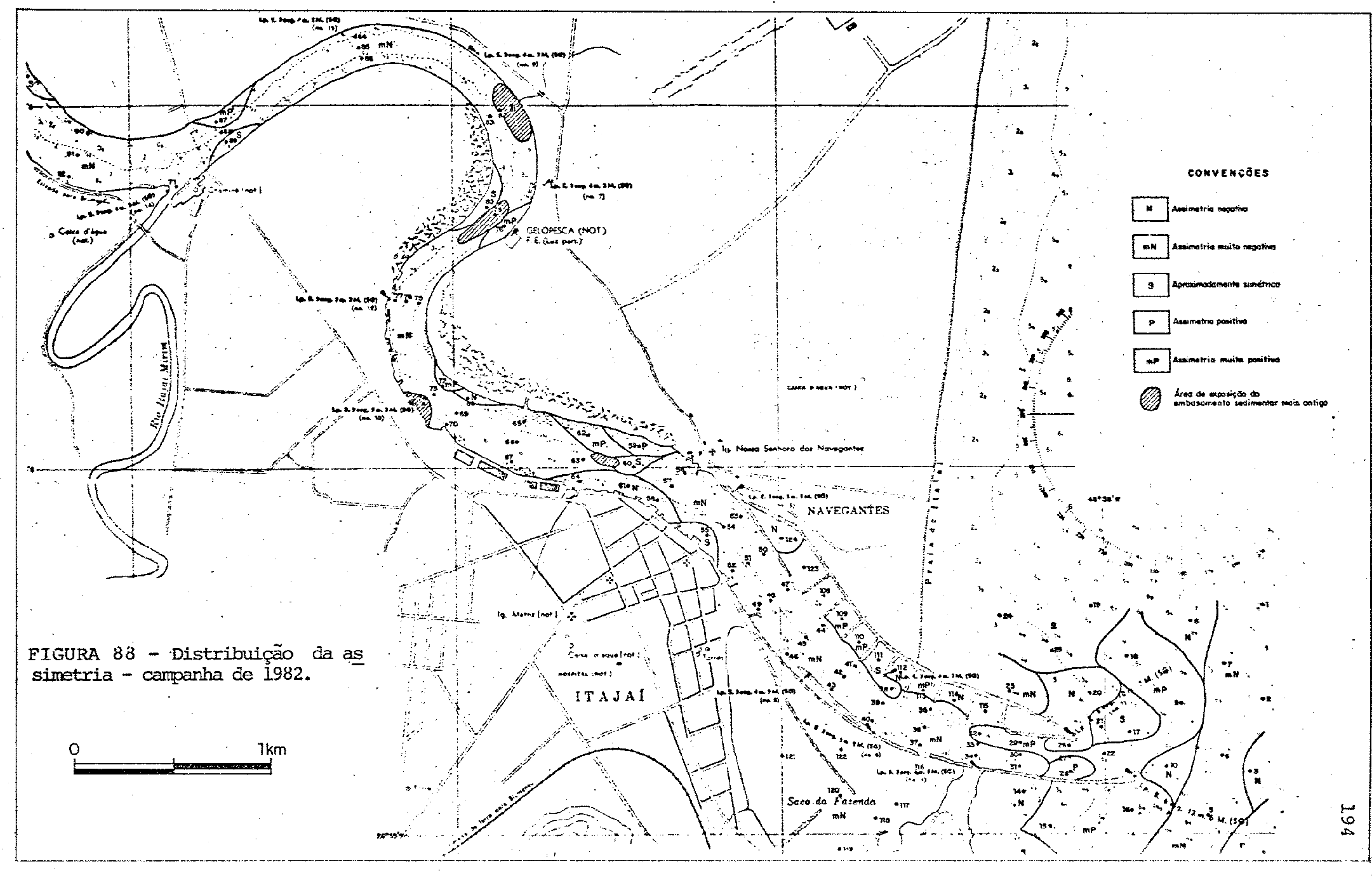


norte-sul, por ocasião das mudanças de rumo de corrente costei ra. Entretanto, nota-se que há uma continuidade das areias do banco para o interior do estuärio, conforme mencionamos, para a qual provavelmente contribuern fatores locais, quais sejam, correntes associadas ao prisma de maré.

Para o interior do estuārio, atē o final da bacia de evolução, dominam siltes finos e siltes muito finos, com as exceções a seguir discutidas.

Nas proximidades da amostra 62 delineia-se um banco arenoso (areia muito fina) que se expande para jusante na mancha de siltes mëdios das amostras 59 e 60 .

Siltes médios são ainda encontrados entre os espigões do molhe norte, até a altura da amostra 109.

Essa distribuição concorda bastante com a discutida no mapa an terior, e pode ser da mesma forma interpretada.

Entretanto, alguns outros elementos tornam-se agora mais suges tivos: a mancha de siltes médios (amostras 59 e 60) alongan do-se para jusante, bem como a Iaixa de siltes finos famostras $70,68,65,63,64,61,58,57$ e 55) que se colocam em contjnuidade com o banco de areia, e que também. se espalham para jusante, parecem indi. car que o crescimento do banco de areia (amostra 62) se faz mais por acreção de material vindo de montante, ou seja, do rio, que de material arenoso da plataforma.

Ao longo dos espigões do molhe norte coloca-se uma faixa de siltes finos que chega a atingir o molhe sul à altura da amos tra 40. Por sua ligação imediata com o material mais. grosso que adentra o estuärio, sugerem que as correntes de enchente possam carrear sedimentos até pouco a montanté da amostra 50 , ou seja, quase até o final do molhe norte: Esta constatação es tende significativamente a área de influência de sedimentação por efeito de marēs, que o mapa precedente indicava situar-se cerca do espigão que se coloca entre as amostras 108 e 109. Nesse sentido, a mancha de siltes finos próxima da amostra 49 tanto pode representar uma migração para jusante dos siltes fi nos, que chegam até a amostra 55, como se constituir de mate rial de fuga do terrapleno, ou ainda estar associada à penetra ção da ãgua salina. 
sul e situada entre as duas áreas de assimetria negativa pri meiramente citadas, estendendo-se para o estuário até pouco além da amostra 32. Esta faixa parece indicar, fora da barra, uma região de interferência entre a corrente costeira e a zona de deriva $\mathrm{N}-\mathrm{S}$ adjacente ao molhe norte. Barra adentro, deve cor responder à zona de māxima interferência entre a ăgua salina e - fluxo fluvial, indicando, pois uma região em que se pode es perar assoreamento importante por decantação de finos.

Mais para o interior do estuārio, é interessante notar que pou cas äreas de assimetria positiva, situadas entre os espigões do molhe norte, devem denotar acreção de material com adição de finos.

A mancha de sedimentos de assimetria positiva junto às amostras 59 e 62, demarca a presença de um banco de areia, sugerin do que durante seu crescimento haja adição de finos:

A mancha de sedimentos simëtricos no entorno da amostra 55 po de ser indicátiva de uma tendência à formação de um banco de sedimentos ao longo dạuela faixa do càis.

A distribuição de assimetrias negativas no Saco da Fazenda é curiosamente sugestiva de boa movimentação de suas águas. Esta indicação deve, porém, ser ainda tomada com reservas.

e) Curtose

- pađrão de distribuição da curtose mostra que valores lepto cúrticos ocorrem de ambos os lados externos dos molhes norte e sul, na foz do estuário, e a montante, além da seção 78-79-80. Valores platicūrticos dominam o restante da ārea (FIGURA 89).

Se admitirmos que as populações leptoçurticas descrevem populações mais homogêneas, e as platicürticas mais heterogêneas , com relação ao agente de transporte, ou com relação à área-fon te, torna-se possivel a interpretação que segue.

Os sedimentos leptocúrticos da plataforma estariam associados à faixa de movimentação de sedimentos pröxima da zona de surf, havendo então tendência à constituição de populações adaptadas a essas condições dinâmicas. Mais ao largo, passariam a dominar sedimentos constituidos pela mistura de diversas popula ções, dada a deriva de sedimentos ao longo da costa, bem como à pröpria contribuição estuarina. 


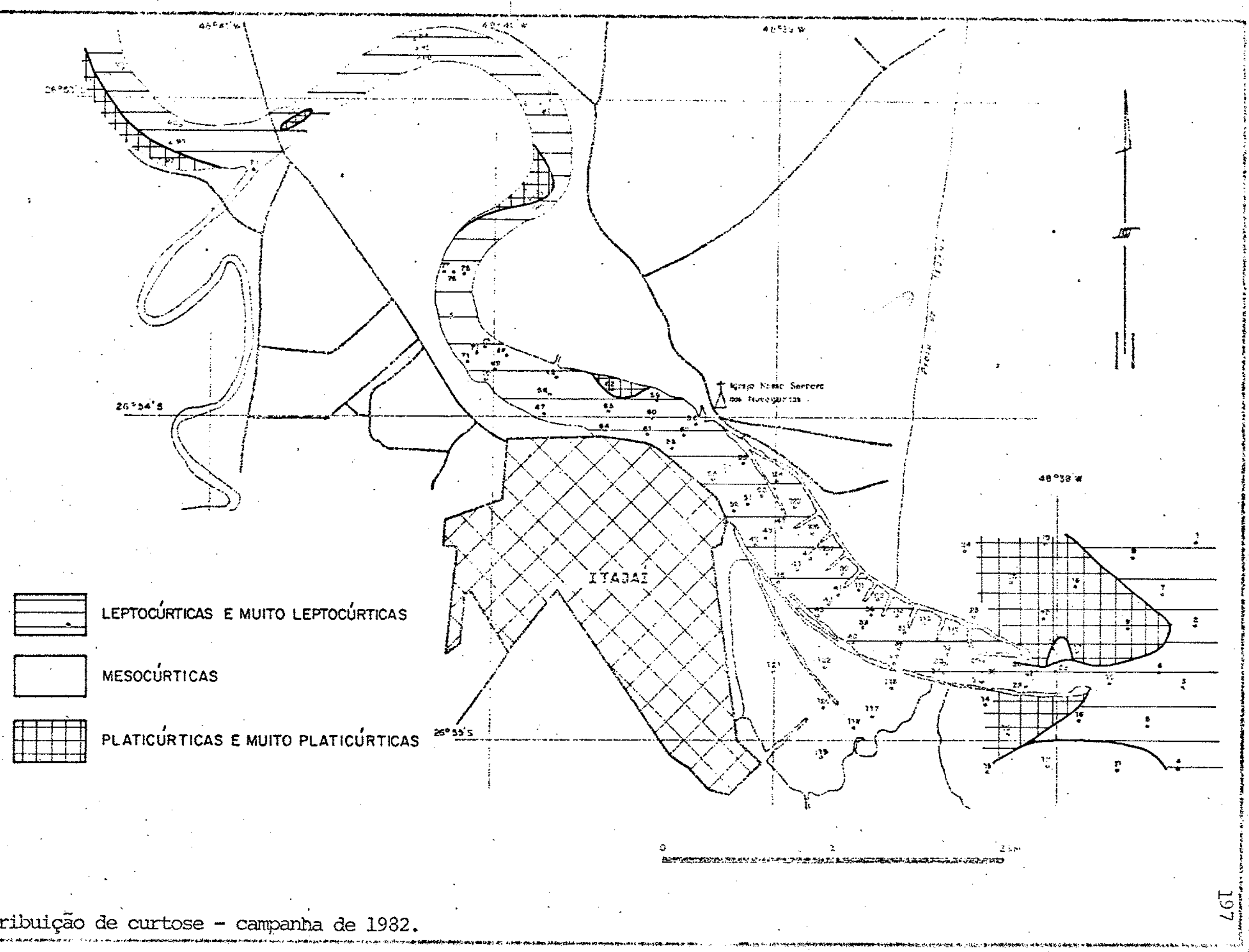


No interior do estuário, pode-se notar que faixas leptocúrticas ocupam as concavidades dos meandros, opostas a faixas platicū ticas, estas onde hä acreção de material sedimentar.

Usando este indicador, de modo empirico, parece-nos poder, ten tativamente, distinguir uma zona estuarina, caracterizada por adição de diferentes populações originais, desde a foz até a seção 87-88-89, a montante da qual caracterizar-se-ia o mencio nado padrão fluvial.

f) Distribuição das porcentagens de areia

Com o objjetivo de avaliar a distribuição de material arenoso na ārea de interesse foram plotadas em planta as porcentagens em peso das classes granulométricas superiores a $0,062 \mathrm{~mm}$, para - conjunto das amostras analisadas.

Após a plotagem, foram estabelecidos arbitrariamente os inter valos: 0 a $10 \%, 10$ a $20 \%, 20$ a $50 \%$ e maior que 50\%, e em seguí da traçadas as respectivas curvas de isovalores.

A separação das classes granulométricas correspondentes às areias (maiores que $0,062 \mathrm{~mm}$ ) tem importância realçada devido aos diferentes modos de transporte dos materiais arenosos e silto-argilosos.

Os materiais arenosos, embora também possam ser transportados em suspensão, são predominantemente transportados por arraste de fundo, especialmente em condições estuarinas; onde as velo cidades de fluxo não são geralmente altas o suficiente para manter areias em suspensão.

Já o material silto-argiloso mais fino, mesmo em condições de menor energia do meio (menor velocidade e turbulência), ainda pode ser mantido em suspensão, sendo este seu modo preferencial de transporte.

A partir do mapa das porcentagens de areia no estuärio do Itajai-Açu (FIGURA 9Ql é possível separarmos três setores, dis tintos quanto às distribuições do material arenoso nas amos tras.

O primeiro setor, situado a montante do perfil das amostras 6869-70, é caracterizado por maiores quantidades de material are noso disposto em faixas estreitas e alongadas localizadas nas margens convexas. Nas margens côncavas e nas porçöes centrais 


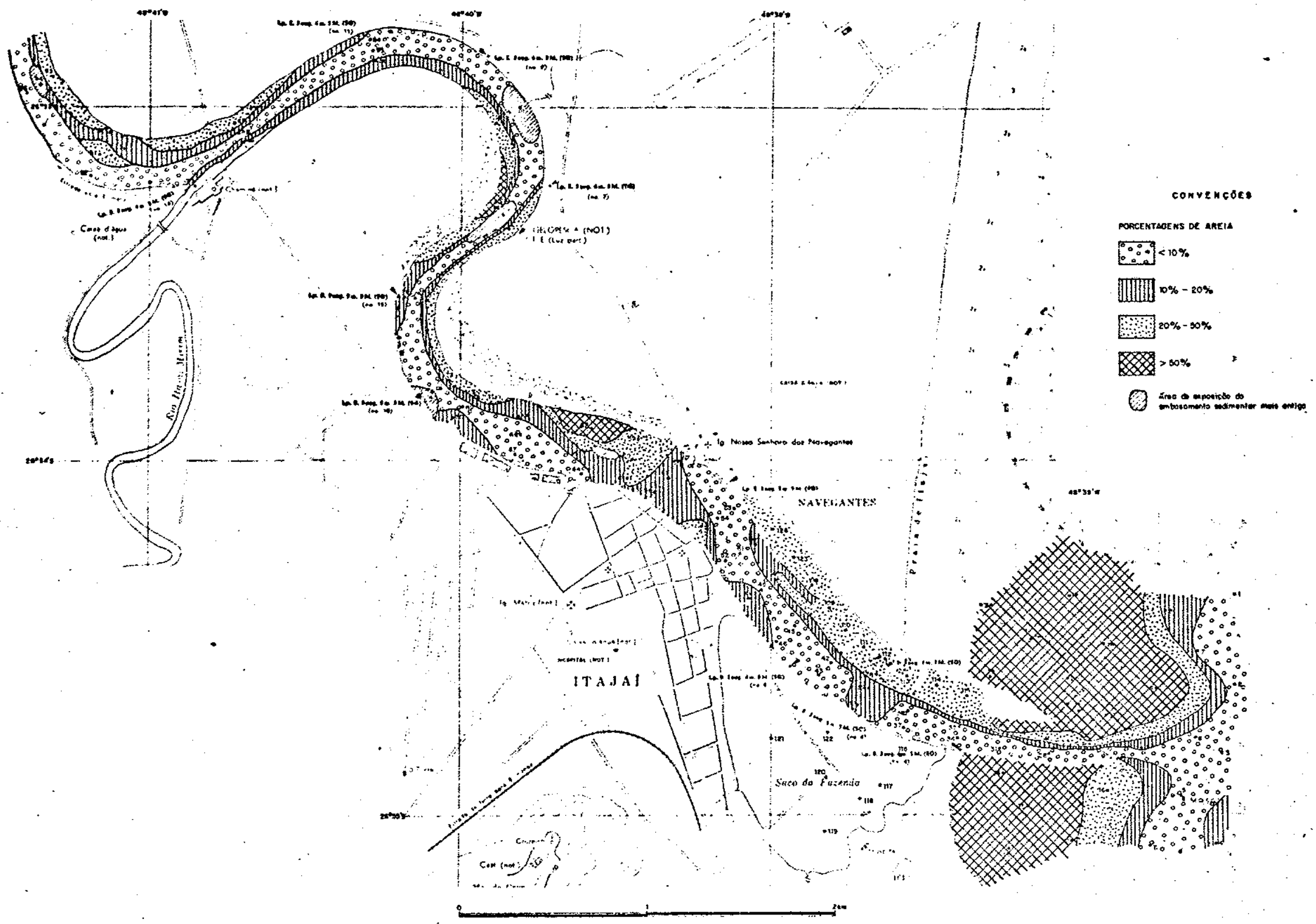

FIGURA 90 - Distribuição das porcentagens de areia. 
do canal encontram-se sempre amostras com teor de material are noso inferior a $10 \%$ (em média de 1 a $5 \%$ ), sendo que em alguns locais (ponto 81 p.ex.l observou-se a exposição do embasamento sedimentar mais antigo, atestando a predominância de processos erosivos.

Esta distribuição de material arenoso sugere uma circulação se melhante à de canais fluviais meandrantes, onde as máximas ve locidades de fluxo concentram-se nas margens côncavas, havendo uma diminuição de velọcidade, e consequente deposição de mate rial arenoso nas margens convexas.

o mesmo padrão de distribuição de material arenoso, mantém - se para as amostras localizadas mais a montante (96 a 107).

o segundo setor, coloca-se a jusante do perfil das ámostras 68-69-70, estendendo-se até a barra, e apresenta uma distribui ção de material arenoso diversa da anterior.

Neste setor, embora ainda haja uma certa tendência de concen tração de material arenoso junto às margens convexas, o padrão mostra-se majs complexo, eviajencianao a interferência de oú tros processos na distribuição do material arenoso.

Imediatamente a jusante da bacia de evolução, englobando as amostras 63-64, 60-61 e 56-56-58, observa-se uma ärea de maio res concentrações de material arenoso, disposta transversalmen te ao canal, truncando o padrão anteriormente observado.

E provãvel que a maior concentração do material arenoso neste local seja o resultado da deposição comandada pelo barramento imposto pelas marēs ao fluxo fluvial, que teria sua velocidade, reduzida ao máximo neste trecho do canal do Itajai-Açu.

Mais a jusante, nas proximidades das amostras 39-40, encontra-se outra áxea de maior concentração de material arenoso, dis posta transversalmente ao canal. Esta segunda área apresenta a mostras com menores quantidades de material arenoso (teor mäxí mo $=16 \%$ l e também encontra-se menos desenvolvida.

Na margem esquerda e mais proxima à barra, nas proximidades dos espigões, coloca-se uma estreita faixa de maiores concentrações de material arenoso, que se estende até a amostra 50. Mais pró ximo à barra e ao molhe norte (amostras 26 e 29) os teores de areia são superiores a $50 \%$, enquanto que no restante observam-se concentrações de 10 a $20 \%$ e 20 a $50 \%$. 
Esta distribuição de material arenoso é sugestiva de arraste de fundo comandado pela movimentação da água marinha, que encontra suporte adicional quando se observa composição da amostra 29. Nesta amostra observou-se na porção superior areia fina ", sem argila, em contato brusco com material fino, silto - argilo sa, sugerindo um avanço de material arenoso marinho em direção ao interior do estuário.

Finalmente, o ültimo setor, que se localiza barra afora, apresenta as maiores concentrações de material arenoso (aproximada mente 12 amostras essencialmente arenosas). Neste setor as maiores concentrações de material arenoso correspondem ao domí nio dos processos costeiros praiais.

As áreas com teor superior a $50 \%$ passam de forma relativamente brusca, atravēs de estreitas faixas de orientação aproximada sul-norte, para as āreas de dominio de material fino localizado mais longe da barra.

Observa-se uma estreita passagem de material fino (teores infe riores a 10\% de areia) que iiga o interior do estuario às areas de domínio de material fino situadas barra afora. Esta situação sugere uma saída de material fino do estuário, que é dis persado pelas correntes costeiras (sul-norte e norte-sul), indo depositar-se mais distalmente sobre a plataforma continental.

g) Anälise de minerais pesados

Os dados referentes à anālise de minerais pesados de 35 amos tras regularmente distribuidas por toda a närea es tudada, foram tratados por anālise de agrupamento, segundo os coeficientes de Pearson e de distância.

No presente estudo pode-se dizer que o coeficiente de distân cia pode ser ütil na detecção de similaridade entre amostras, independentemente da fonte, pois que se baseia em valores por centuais absolutos dos minerais pesados. Já os grupos obtidos pelo coeficiente de pearson seriam mais indicativos de derivações de sedimentos de suas āreas fontes, imaginando-se que va lores porcentuais possam variar com a distância da ārea-fonte, mantendo, entretanto, suas proporções relativas.

Para se efetuar uma anälise de agrupamento, é necessārio com por uma matriz numérica de dados, em que teores iguais a zero 
devem ser evitados, para que não se efetuem correlações por au sência. Examinando-se a FIGURA' 91 , percebe-se que apenas cinco variāveis satîsfazem a essa condição: epídoto, hornblenda, hi perstênio, turmalina e zircão. Nas amostras em que essas variā veis ocorrem como traços, foi-lhes atribuído um valor arbitrā rio de 0,1 para efeito numërico.

- Amostras com teor de areia superior a $10 \%$

A anälise de minerais pesados em amostras mais arenosas, visou à determinação da proveniência do material transportado por ax raste que forma os bancos arenosos que crescem nas convexidades dos meandros fluviais e estuarinos do Itajai-Açu, bem como do material que vem assoreando a região dos espigões do molhe nox te.

De montante para jusante, ao longo do estuärio, foram escolhi das as amostras 93, 97, 83, 88, 62, 59, 60, 55, 109, 110, 111, 112, 113, 114 e 115, bem como as amostras $5,15,16,17,18$ e 25, estas em dominio marinho. A amostra 5 foi incluida, apesar de ter pouco menos de 10 \% de areia, por situar-se em posição de interesse para correlação.

Os agrupamentos pelo coeficiente de Pearson, ou de similarida de, podem ser visualizadas no dendrograma da FIGURA 92 , sendo sugestivos os seguintes grupos:
a) 17,18
b) $83,60,68,113,25$
c) $87,115,93,55$
d) $15,110,62,109,114,112,59,16,5$

Este ültimo grupo aparentemente comporta subdivisões. Entretanto, è mais conveniente caracterizar um ünico grupo, pois os coeficientes de correlação são muito elevados, havendo mesmo a possibilidade de que as pequenas variações dentro do grupo d sejam dadas pelos próprios processos de cálculo (e suas aproxí mações) do mëtodo empregado. 
MNERAIS

ANOSTRAS

Anatāsio

Andaluzita

Anfibólio Incolor

Apatita

Clinopiroxēnio

Carbonato

Cianita

Epidoto

Estaurolita

cranada

Hornblenda

Hiperstēnio

Rutilo

- Siderita

Sillimanita

Titanita

Turmalina

Zircão

Outros

Opacos

Semi-opacos

Agreg.Sericitico

Fosfato Biogênico

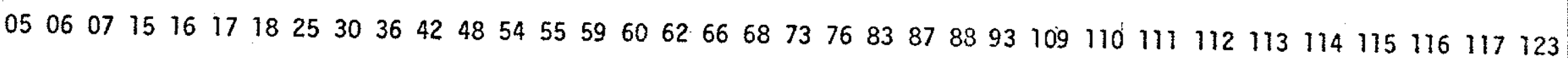
tr - tr tr tr - tr tr - tr tr tr - tr - tr tr - 1 1 1 - $-\operatorname{tr} \operatorname{tr}-\operatorname{tr}$ $\operatorname{tr}-\operatorname{tr} \operatorname{tr} \operatorname{tr} \operatorname{tr} 1 \operatorname{tr} \ldots-\operatorname{tr} \operatorname{tr} \operatorname{tr} \operatorname{tr} \operatorname{tr} 1 \operatorname{tr} \operatorname{tr} \operatorname{tr}-$ - tr tr tr - tr $21-11 \operatorname{tr} \operatorname{tr} \operatorname{tr} 11 \operatorname{tr} 11 \operatorname{tr} \operatorname{tr} 2 \operatorname{tr} 1 \operatorname{tr} \operatorname{tr} \operatorname{tr} \operatorname{tr} \operatorname{tr} \operatorname{tr} 1 \operatorname{tr} \operatorname{tr}$ $\begin{array}{llllllllllllllllllllllllllllllll}1 & 1 & 1 & 1 & 2 & 2 & \operatorname{tr} & 3 & 2 & 3 & 1 & 1 & \operatorname{tr} & 1 & 3 & 1 & 1 & \operatorname{tr} & 1 & 1 & \operatorname{tr} & \operatorname{tr} \operatorname{tr} & 1 & 1 & 1 & 1\end{array}$

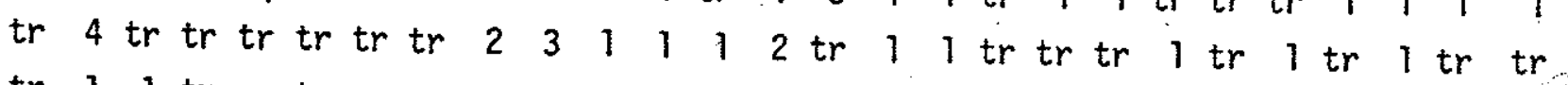
$\operatorname{tr} 11 \mathrm{tr}-\operatorname{tr}-$ - tr - tr tr tr - - - tr - $111 \mathrm{tr}-\operatorname{tr}-\mathrm{t}_{-}$ tr - tr tr tr tr tr tr tr tr - tr tr tr tr tr - tr tr - tr - tr - - tr tr

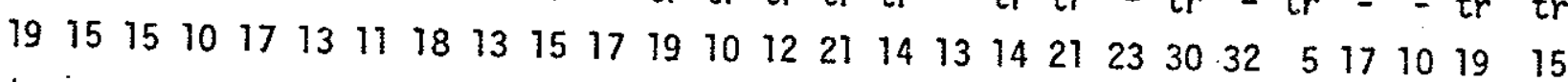
$\operatorname{tr}-$ - $\operatorname{tr} \operatorname{tr} 22 \operatorname{tr}-\ldots \operatorname{tr}-\operatorname{tr} \operatorname{tr} \operatorname{tr} \operatorname{tr} \operatorname{tr} \operatorname{tr} 1-\operatorname{tr} \operatorname{tr} \operatorname{tr}-\operatorname{tr} 1$ tr - tr 1 tr tr 1 tr tr - - tr tr tr tr tr tr tr tr tr 1 tr tr tr tr tr tr $\begin{array}{llllllllllllllllllllllllllll}48 & 43 & 28 & 22 & 32 & 10 & 17 & 23 & 39 & 40 & 38 & 41 & 43 & 55 & 39 & 18 & 25 & 27 & 22 & 25 & 21 & 19 & 28 & 30 & 43 & 30 & 28\end{array}$ $\begin{array}{lllllllllllllllllllllllllll}2 & 2 & 1 & 2 & 1 & 1 & 1 & 3 & 2 & 1 & 1 & 3 & 3 & 2 & 2 & 7 & 1 & 1 & 1 & 1 & 1 & \operatorname{tr} & 3 & 1 & 1 & 3 & 1\end{array}$ $\operatorname{tr} \operatorname{tr} \operatorname{tr} \operatorname{tr} 1221 \operatorname{tr}-\quad-\operatorname{tr}-\ldots-11 \operatorname{tr} t r-1 \operatorname{tr} t r \operatorname{tr} 1 \mathrm{tr}$ $\operatorname{tr} 2---\operatorname{tr}-\operatorname{tr}--$ - tr $-2-\operatorname{tr}-\operatorname{tr} \operatorname{tr} \operatorname{tr}-1 \operatorname{tr} t r-t r-$ tr tr tr tr tr - tr 2 tr tr - tr tr tr - tr 1 tr tr tr tr tr $-2 \operatorname{tr} t r \operatorname{tr}$ $\begin{array}{llllllllllllllllllllllllllll}3 & 2 & 4 & 3 & 2 & 3 & 4 & 6 & 4 & 3 & 1 & 3 & 4 & 2 & 4 & 3 & 4 & 2 & 2 & 7 & 8 & 4 & 5 & 4 & 3 & 4 & 5\end{array}$ $\begin{array}{lllllllllllllllllllllllllllll}1 & \operatorname{tr} & 4 & 9 & 3 & 10 & 16 & 6 & 9 & 1 & 2 & 1 & 2 & \operatorname{tr} & 2 & 2 & 6 & 4 & 5 & 8 & 3 & 6 & 8 & 16 & 5 & 5 & 8\end{array}$ tr tr - - tr tr tr tr tr - - tr tr - - - tr - t tr tr - $-\operatorname{tr}$ $\begin{array}{lllllllllllllllllllllllllll}10 & 21 & 25 & 35 & 30 & 55 & 36 & 25 & 16 & 12 & 14 & 21 & 18 & 10 & 18 & 35 & 38 & 35 & 33 & 18 & 13 & 11 & 46 & 18 & 15 & 28 & 25\end{array}$ $\begin{array}{lllllllllllllllllllllllllllll}13 & 7 & 16 & 13 & 10 & 3 & 10 & 11 & 10 & 15 & 22 & 8 & 16 & 12 & 9 & 15 & 8 & 15 & 13 & 10 & 16 & 24 & 4 & 7 & 18 & 10 & 13\end{array}$ $\operatorname{tr} 112 \operatorname{tr}-\operatorname{tr}-153 \operatorname{tr} 211 \operatorname{tr} \operatorname{tr} \operatorname{tr} \operatorname{tr} 322-3 \operatorname{tr}-2$

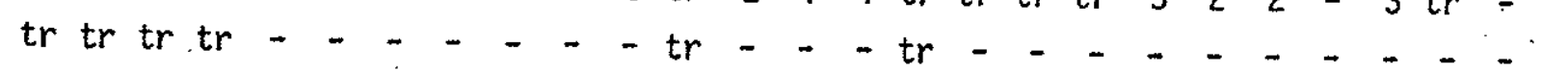
tr - tr $-\quad-1$ tr $\operatorname{tr} 1 \operatorname{tr} .2 \operatorname{tr} \operatorname{tr} 13 . \mathrm{tr}$ $\operatorname{tr} 1 \operatorname{tr} \operatorname{tr} 1 \operatorname{tr} 11$ $22 \operatorname{tr} \operatorname{tr} \cdot 1 \operatorname{tr} 12$ - - - - tr - - - - - - - -

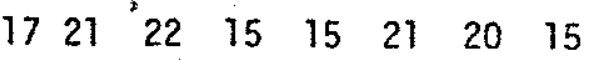
tr tr tr tr - tr - tr tr $\operatorname{tr}$ tr $\operatorname{tr} \operatorname{tr} \quad 1 \quad 1$ $\begin{array}{llllllll}35 & 42 & 29 & 30 & 40 & 43 & 42 & 19\end{array}$ $\begin{array}{llllllll}2 & 1 & 2 & 2 & 5 & 1 & 2 & 2\end{array}$ $-\quad 11-\operatorname{tr} 2-$ $-\quad-\quad-\operatorname{tr}---$ tr tr tr - - - tr - tr tr tr tr $3-2$ $\begin{array}{llllllll}2 & 4 & 7 & 2 & 6 & 2 & 2 & 2\end{array}$ $\begin{array}{llllllll}2 & 3 & 2 & 5 & 8 & 2 & 1 & 3\end{array}$ tr - tr - - tr - 3 $\begin{array}{llllllll}27 & 12 & 26 & 30 & 16 & 10 & 17 & 21\end{array}$ $\begin{array}{llllllll}12 & 13 & 12 & 13 & 8 & 17 & 8 & 25\end{array}$ - tr - $-\operatorname{tr} 132$ FIGURA 91 - Freqtiência de minerais pesados não magnëticos e não micácẹos na fração 0,062 a $0,125 \mathrm{~mm}$. 


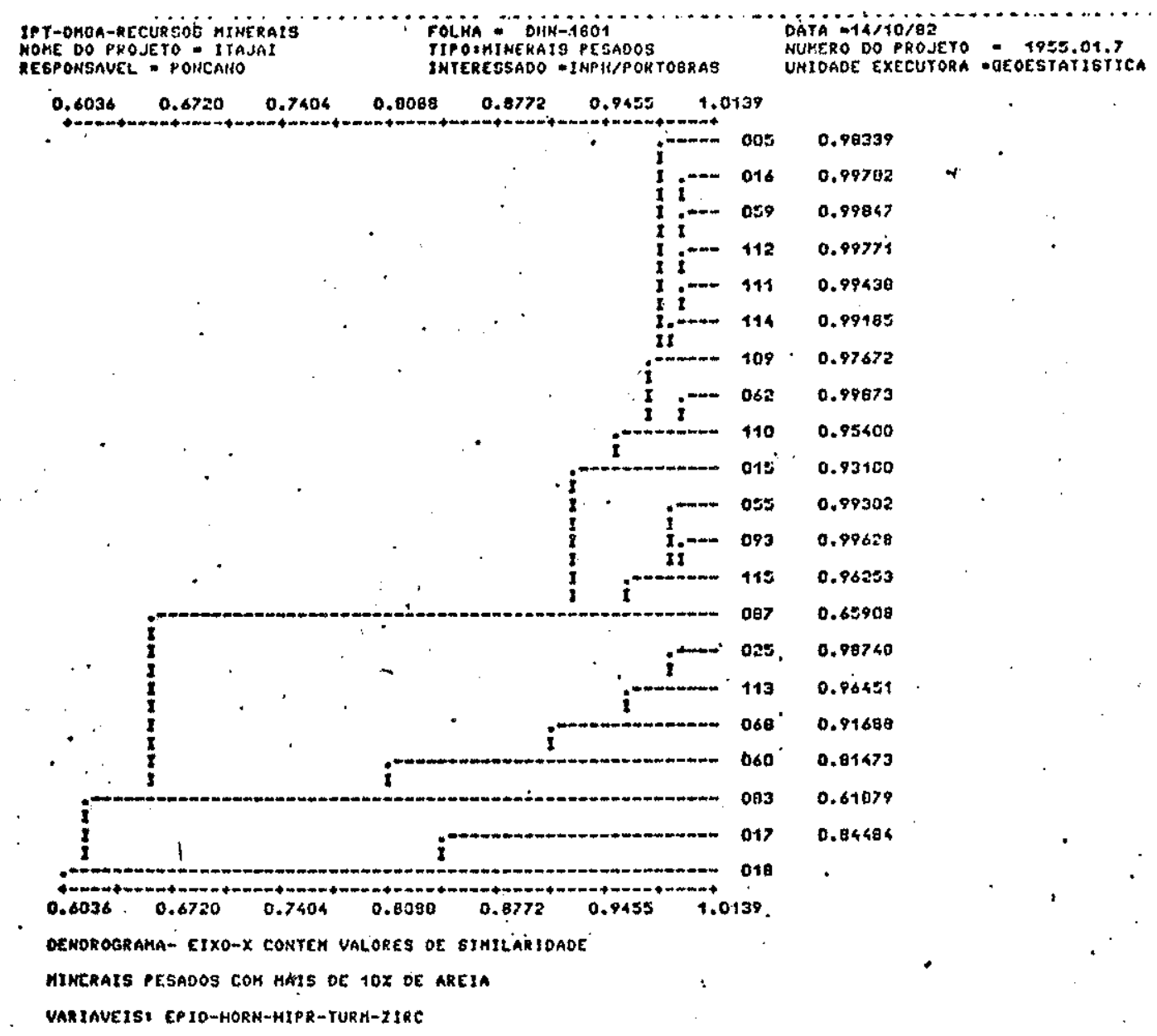

FIGURA 92 - Dendrograma segundo o coeficiente de Pearson para amostras com mais de 10 \% de areia. 
Nota-se ainda que a correlação entre os grupos e e d é elevada $(0,93100)$, diversamente do que ocorre entre os grupos $\subseteq$ e $b$ $(0,65908)$ e $\underline{b}$ e $\underline{a}(0,61879)$.

A distribuição em planta desses resultados pode ser visualisą da na FIGURA 93.

Nela se constata que o grupo a é exclusivamente marinho, não se deixando retraçar para o interior do estuārio, sendo ainda - grupo mais dissimilar dos demais. E provāvel que ele seja re presentativo dos sedimentos arenosos do banco de areia mari nhas, que avança ao longo do molhe norte.

o grupo b engloba amostras que se situam desde o final da área de penetração de āgua salgada (amostra 83) até o domínio mari nho raso (amostra 25). Das quatro amostras estuarinas que com põe este grupo, três situam-se em bancos arenosos $(83,68$ e 60) e uma entre espigões do molhe norte (113). Esta situação é sugestiva de derivação de montante para jusante, ou seja, de um aporte em que predominem as correntes fluviais e/ou de va zantes. A amostra 25 pode estar refletindo uma derivação do ma terial resultante do estuário, quando predominam na zona litorânea correntes de sul para norte, situação que ocorre prova velmente na maior parte do ano.

- grupo $\subseteq$ reúne as duas amostras mais tipicas fluviais (93 e 87), coletadas em pontos em que não hã supostamente penetração de água salobra, e onde o regime fluvial é afetàdo somente por efeitos de barramento das marés, que lhe dimjnuem periodicamen te a capacidade de transporte. Amostras deste mesmo grupo são detectadas no banco em formação à altura da amostra 55 , bem co mo entre os espigões do molhe norte, à altura da amostra 115 . Esta situação é sugestiva de uma derivação de montante para jü sante, ou seja, de uma derivação fluvial.

o grupo d é caracteristicamente estuarino e marinho. No estuärio ë encontrado na margem esquerda, no banco arenoso em cres cimento em frente ao cais, e bacia de evolução (amostras 59 e 62), e tambēm entré os espigões do molhe norte (amostras 109, $110,111,112$ e 114). Em domínio marinho, nas partes mais profun das da ārea investigada (amostras 5 e 16) pode ser retraçadona faixa em que mapas analíticos anteriores indicaram saida de 


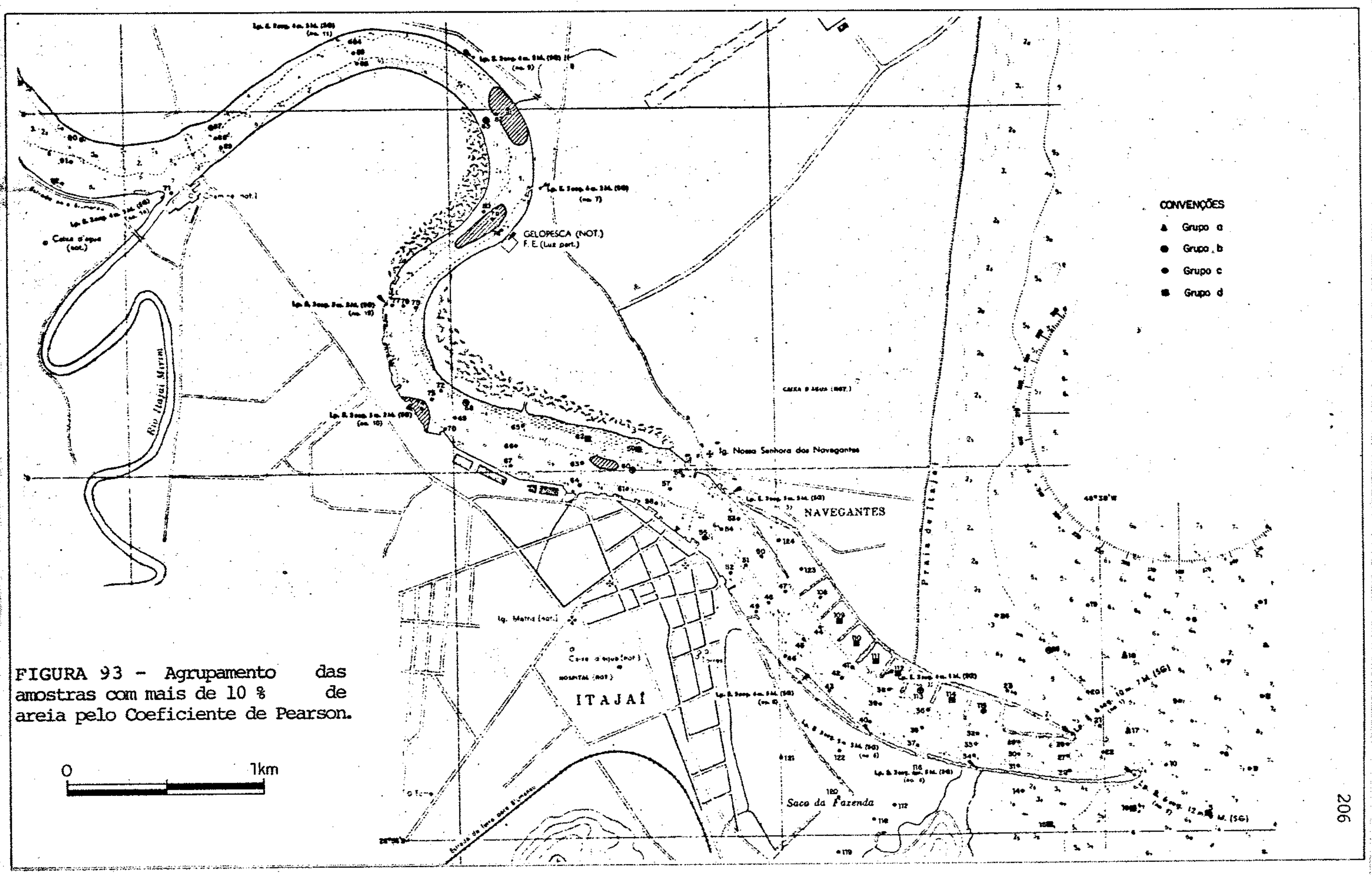


material estuarino. A amostra 15, situada em região mais rasa, também se liga a esse grupo.

Dois pontos merecem ainda destaque. Primeiramente, deve-se no tar que a correlação entre os grupos $\subseteq$ e d é alta (0,93100) ; considerando-se o grupo $\underline{c}$ de origem fluvial, conforme exposto anteriormente, pode-se supor que parte do material constituinte do grupo d seja de derivação continental.

outro ponto a ser considerado è a dissimilaridade das amostras a norte $(17,18$ e 25$)$ e a sul $(5,15$ 16) da saida do estuário. Nota-se que amostras que ocupam posições mais ou menos simétrí cas com relação à saĩda do estuário, pertencem a grupos separa dos por baixos coeficientes de similaridade $(0,65908)$. Esta si tuação é sugestiva de que o engordamento nas partes externas dos molhes norte e sul se faz sazonalmente, de acordo com 0 predomínio da corrente costeira mais próxima para norte ou pa ra sul.

o dendrograma da FIGURA 94 sugere os seguintes agrupamentos de amostras, atravēs do cocficiente de distância:
a) 83 ;
b) 17,18 ;
c) $60,68,25,113,114,109,111,16$;
d) $87,110,62,15$;
e) $55,115,93,112,59,5$.

A distribuição em planta desses agrupamentos pode ser visualizada na FIGURA 95.

A amostra 83 mostra, segundo o coeficiente de distância ora em pregado, baixa similaridade com o restante das amostras analisadas.

o grupo b é característico do dominio marinho, identificando-se com o grupo a segundo o coeficiente de Pearson (item 4.2.2.1). As amostras do grupo c situam-se em sua maior parte no domínio marinho (16 e 25).

o grupo d inclui amostras tipicamente fluvial (87), estuarinas (62 e 110) e marinha (15).

- grupo e mostra distribuição similar à do grupo d, incluindo uma amostra fluvial (93), quatro estuarinas $(59,60,55,112$ e $115 \mathrm{I}$, e uma marinha ( 51 . 


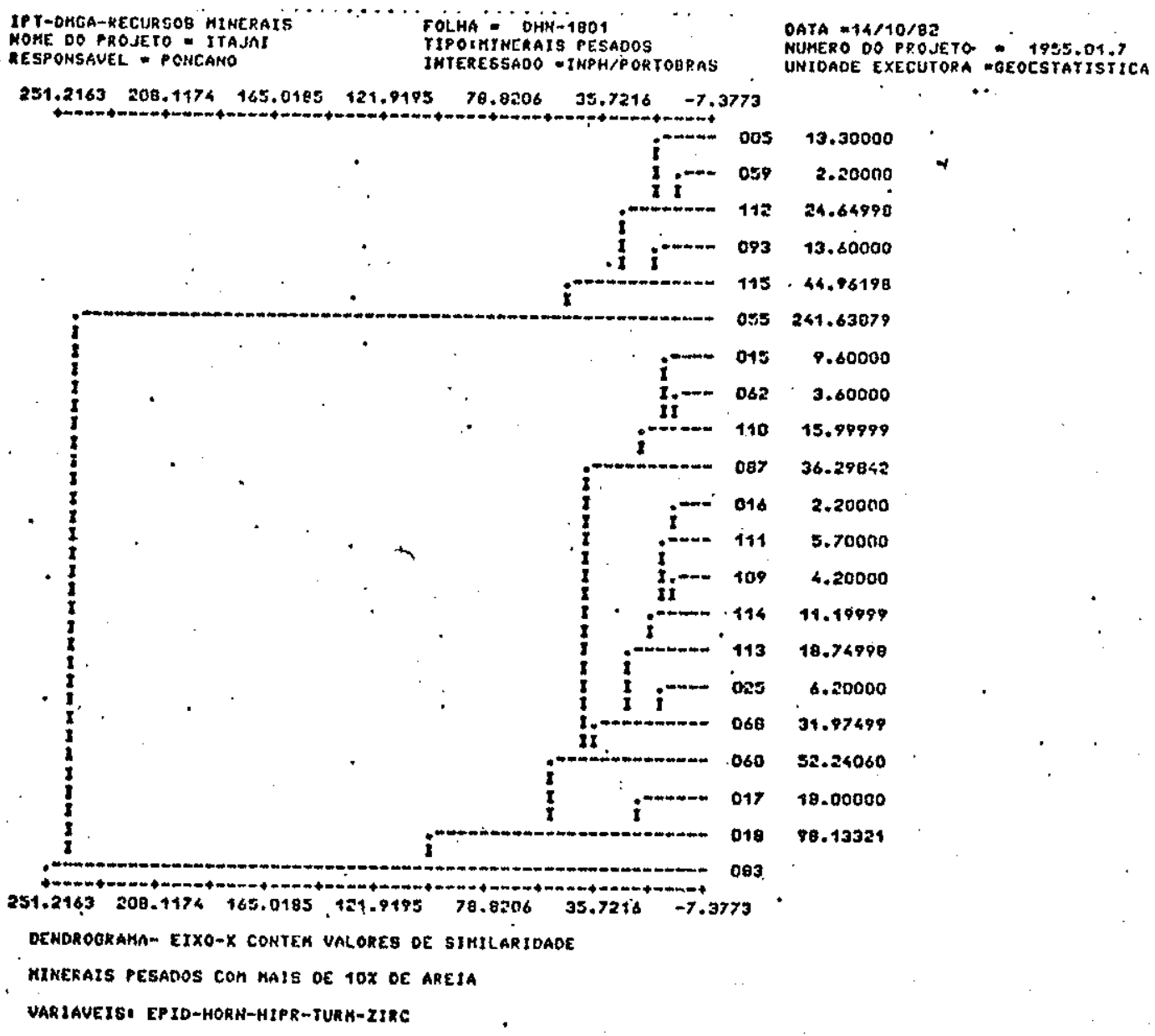

FIGURA 94 - Dendrograma segundo o ceficiente de distância, para amostras com mais de 10 \% de areia. 
Os grupos d e e, que o dendrograma da FIGURA mostra situa rem-se em familias totalmente distintas, separadas pela mäxima distância entre grupos $(241,63879)$ tem um ponto em comum de grande significado: acham-se eles representados em áreas de do minio fluvial, estuarinho e marinho. Isto mostra que, segundo - coeficiente ora utilizado, há uma grande semelhança na compo sição mineralógiea do conjunto das amostras analisadas. Isto se deve provavelmente a que os sedimentos transportados ao longo àa costa reunam tanto contribuições de outras drenagens, como também de material alterado dos pontões rochosos que interrompem as faixas praiais arenosas.

Assim, uma anālise da proveniência e dispersão dos sedimentos arenosos segundo este critério, torna-se mais dificil.

Entretanto, algumas conclusões parciais são possiveis; amostras dos grupos a e e caracterizam os bancos arenosos mais $t \underline{i}$ picamente fluviais (amostras 93 e 87), ocorrendo ainda no ban co defronte ao cais e bacia de evolução (amostras 59 e 62) e no banco em formação no cais no entorno da amostra 55. Daí pa ra jusante, ocorre entre espigões do molhe norte (amostras 112 e 115) e logo após a desembocadura do estuário (amostra 5). Se para estas últimas amostras (5 e 115) pode-se propor, como hi pótese, a entrada de material marinho, o restante da disposi ção das amostras dos grupos d e e sugere maior ligação com se dimentos. fluviais.

Por outro lado, o grupo $c$, o mais numeroso, tem quatro de suas oito amostras entre os espigões de molhe norte, e outras duas no banco arenoso defronte ao cais e bacia de evolução. Este grupo parece ser mais útil na definição dos limites de uma sedimenta ção estuarina, que na definição da proveniência de sedimentos por arraste. Assim, esta região em que a circulação estuarina teria influência na deposição do material transportado por ar raste, ficaria definida da altura da amostra 68 (final da ba cia de evolução) para jusante, justamente onde ocorre a maior parte das amostras do grupo $\underline{c}$, bem como amostras dos grupos $\underline{\text { d }}$ e $\underline{e}$, indicando que é nesse mesmo espaço que ocorre a maior mis tura de sedimentos de composições diferentes.

Complementarmente, deve-se notar que o grupo $\underline{b}$, exclusivamente 
marinho, acha-se bastante distanciado do grupo $\underline{c}$, o que è su gestivo de pouca influência de aporte marinho por arraste do mar para o interior do estuário.

Finalmente, hä tambëm uma coincidência interessante de que amostras dos grupos $\underline{d}$ e e encontram-se a sul da desembocadura do estuário, já que mapas analíticos prévios são sugestivos de um fluxo estuarino para sul, o que reforça um transporte areno so rio abaixo, conforme se discutiu para os grupos $d$ e $e$ ante riormente.

- Amostras com teor de areia menor que $10 \%$

A análise mineralógica das amostras com teores menores que 10\% de areia visou a anălise da origem e distribuição dos sedimentos mais finos, transportados predominantemente por suspensão. Como no caso das amostras mais arenosas, foram usados dois cce ficientes de agrupamento: o de Pearson e o de distância. Levan do-se em conta que estas anālises referem-se, em boa parte, a amostras que se situam em äreas sujeitas a dragagens, os resul tados obtidos devem ser tomados com reservas.

Os resultados obtidos pelo coeficiente de pearson são apresentados no dendrograma da FIGURA.96, e sugerem os seguintes gru pos:

a) 76,123 e 73 ;

b) 88 ;

c) $54,30.117,48,116,42,66,7,36,6$.

Em planta(FIGURA 97) esses resultados mostram que há grande si milaridade na composição dos sedimentos finos do estuário $(66$, $54,48,42,36$ e 30), do Saco da Fazenda (116 e 117) e do domí nio marinho ( 6 e 7), conforme a distribuição do grupo c. E interessante notar que, nesse grupo, as amostras 30 e 54 são ligeiramente diferenciadas. Coincidentemente elas se acham pró ximas de locais mais arenosos (amostras 29 e 50, respectivamen te), o que è sugestivo de uma contaminação (natural) das assem blëias mineralógicas.

Duas amostras do grupo a $(73$ e 76$)$ são indicativas de uma mu dança na composição mineralógica do moterial transportado em suspensão, pouco a montante da bacia de evolução. E possível 


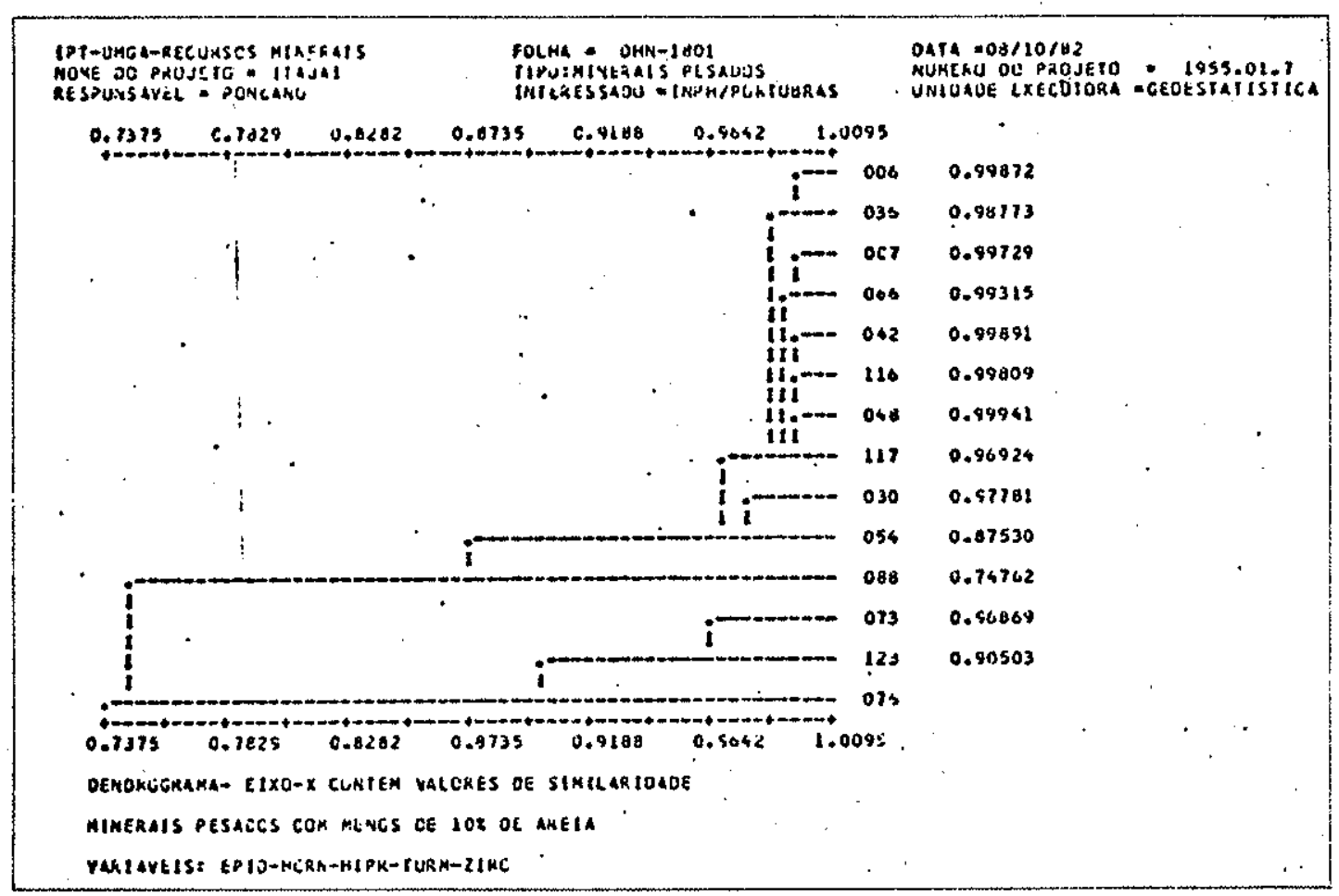

FIGURA 96 - Dendrograma segundo o coeficiente de Pearson, para amostras com menos de 10 \% de areia.

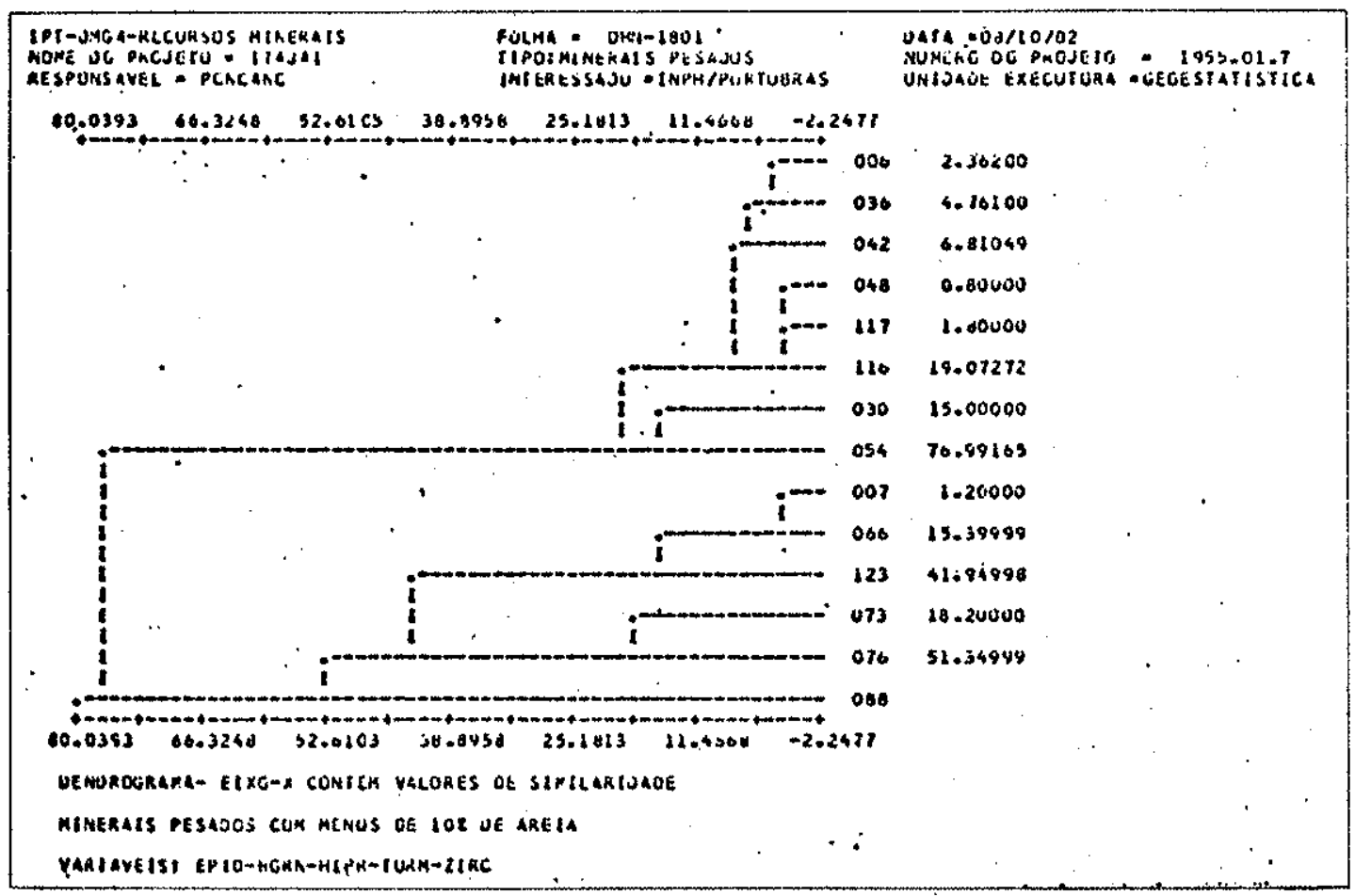

'FIGURA 98 - Dendrograma segundo o coeficiente de distância, para amostras com menos de 10 \& de areia. 


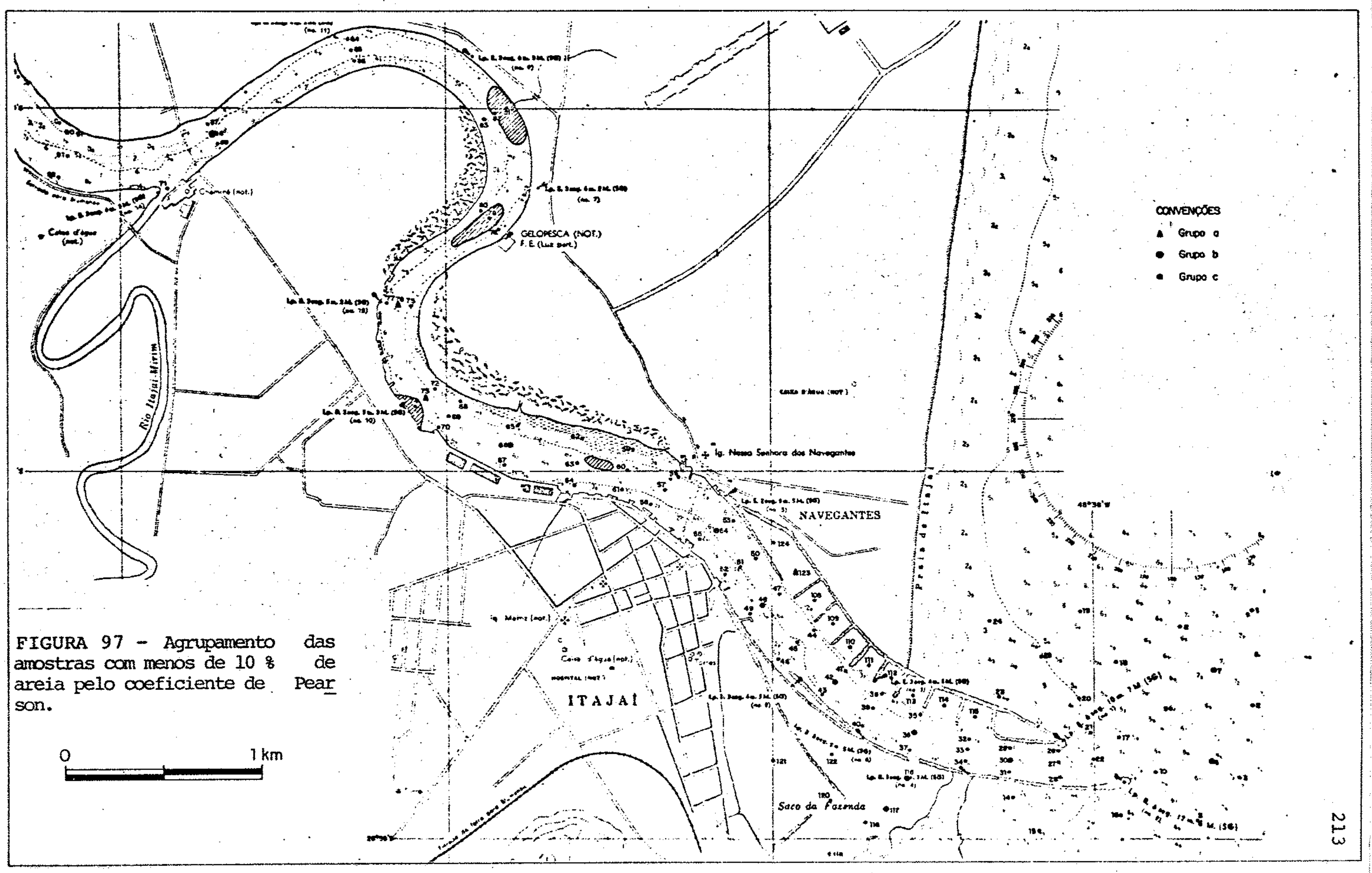


que esse șeja o limite máximo montante, da maior influência da circulação estuarina, na deposição do material em suspensão: os resultados de agrupamentos de amostras obtidos através do coeficiente de distância estão sintetizados nas FIGURAs 98 e 99 compondo os seguintes grupos:
a) 88 ;
b) 76 e 73;
c) 123,66 e 7;
d) $54,30,116,117,48,36,6$;

A discriminação de outros grupos na familia de amostras do grupo d mostrou-se improdutiva do ponto de vista interpretati vo. Assim, a distribuição de grupos indicados pelo coeficiente de distância corresponde grandemente à. indicađa pelo coeficien te de Pearson.

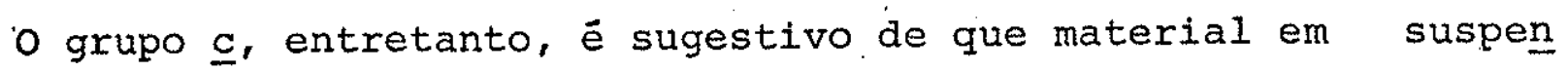
são marinho (amostra 7) possa se depositar até a altura da ba cia de evolução (amostras 123 e 66). Torna-se também significativa a situação da amostra 66 , pertencente ao grupo d, caracte rístico do estuário, pois estaria colocada em local de passa gem do fluxo resultante do estuário.

Análise de agrupamento integrada das amostras

o total das 35 amostras analisadas do ponto de vista mineraló gico foi analisado em conjunto, visando-se estabelecer analogamente entre os diferentes tipos de sedimentos, transporta dos por arraste e por suspensão.

Através do coeficiente de Pearson, obteve-se o dendrograma da FIGURA 100 .

Dada a grande variação da composição granulomētrica das amos trras envolvidas, os agrupamentos a seguir listados são aqueles melhor evidenciados pelo dendrograma, com algumas simplifica ções, estabelecendo-se porēm um minimo de similaridade de 0,90 para o conjunto das 30 primeiras amostras listadas no dendro grama. São assim reconhecidos os seguintes grupos principais:
a) 18,17 ;
b) 76,83 ; 


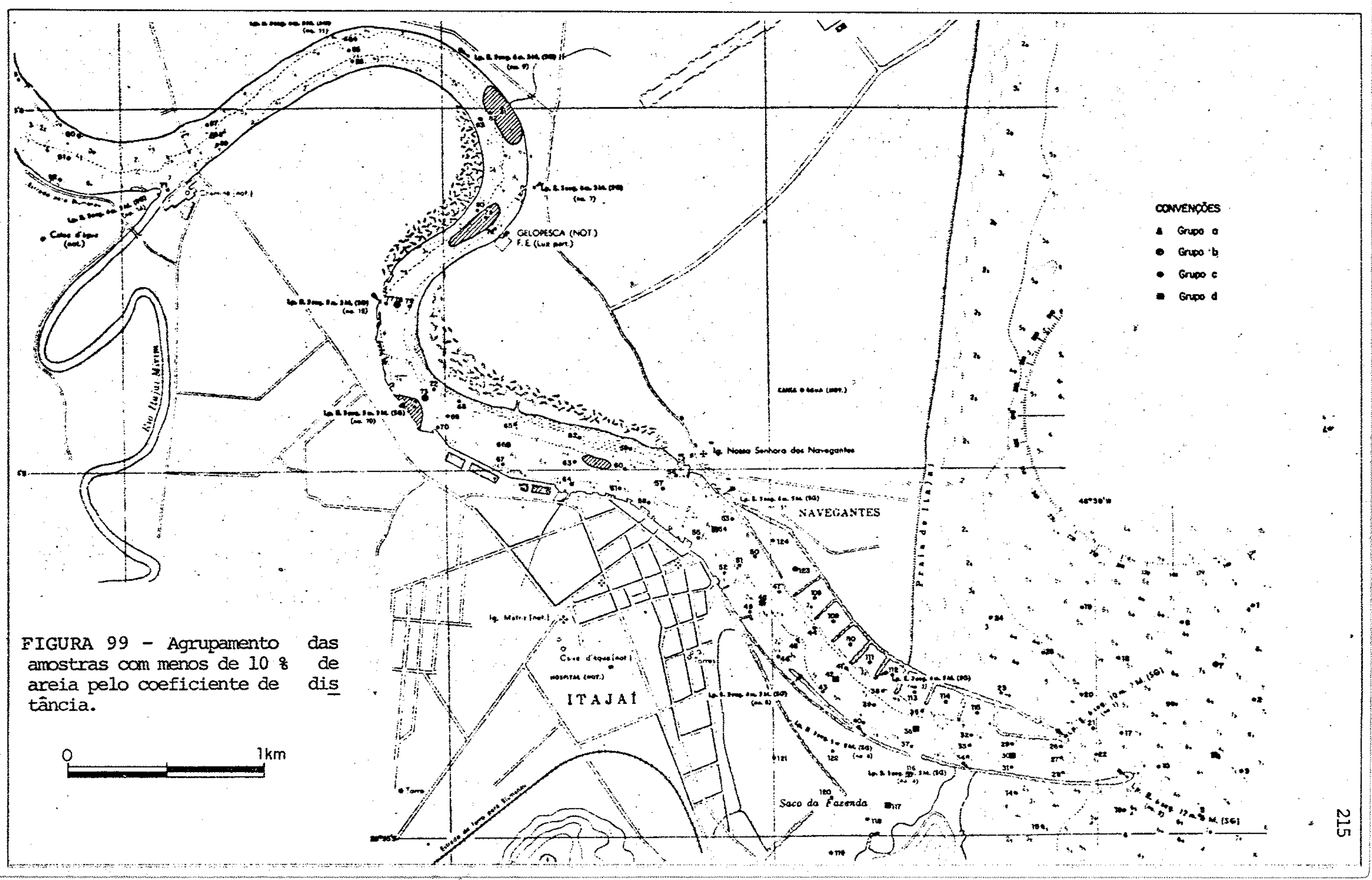




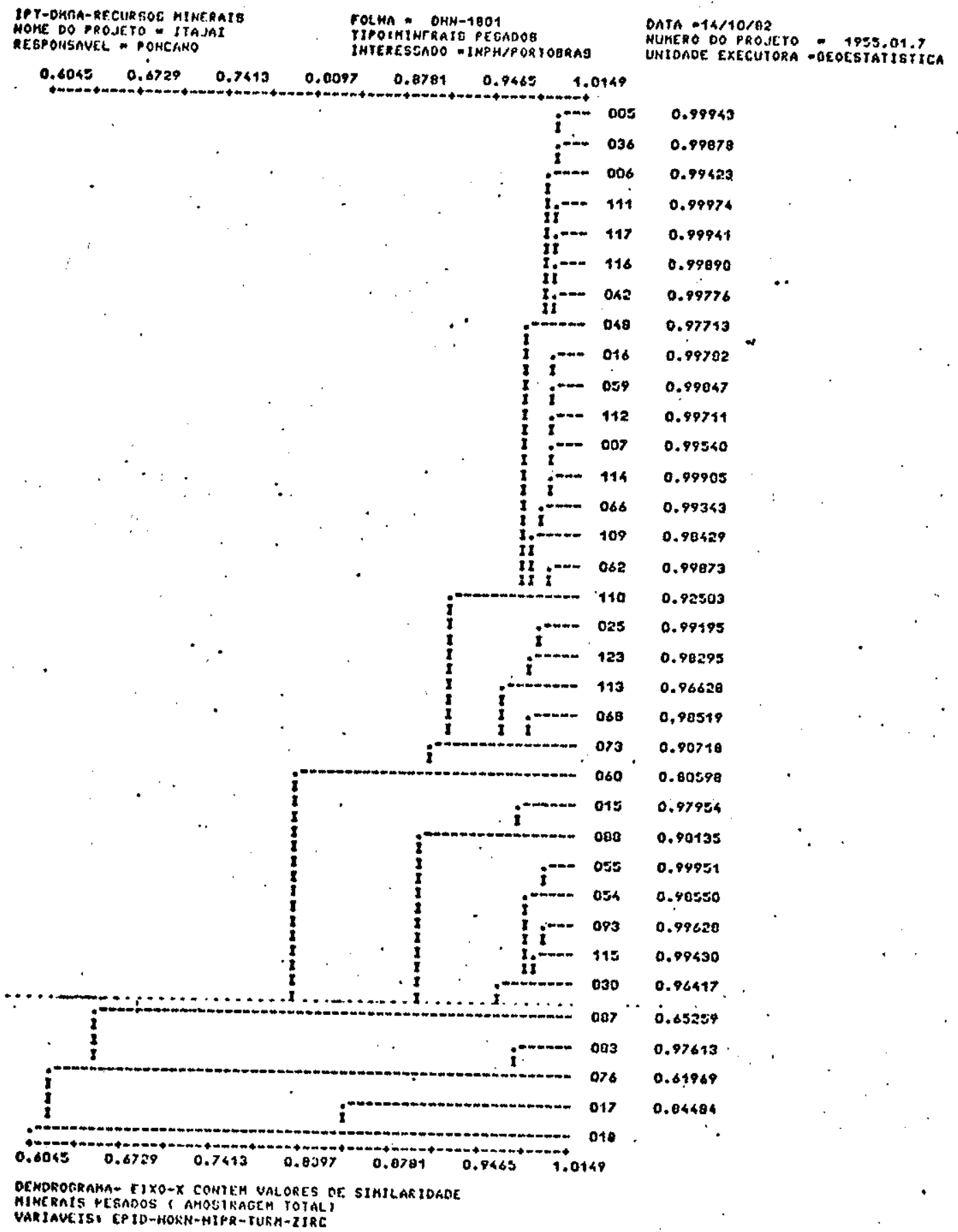

FIGURA 100 - Dendrograma segundo o coeficiente de Pearson para todas as amostras analisadas petrograficamente. 
c) $87,30,115,93,54,55,88,15$;

d) $60,73,68,113,123,25,110,62,109,66,114,7,112,59$, $16,48,42,116,117,111,6,36,5$ :

A distribução destes grupos em planta é mostrada na FIGURA 101.

o grupo a, exclusivamente marinho, já foi mostrado atravēs de anālises prēvias.

- grupo $\underline{b}$ contēm uma amostra de banco arenoso do final do es tuārio (83) e uma amostra fina (76), sugerindo deriva para jü sante de material fino em suspensão.

- grupo c mantēm uma amostra marinha (15) e duas próximas à desembocadura do estuário (30 e 115). Por outro lado, inclui amostras francamente fluviais $(93,87$ e 88) e francamente es tuarinas (54 e 55).

Sabe-se que hã inversão sazonal da corrente costeira, o que permitiria tecer hipōtese a respeito da semelhança entre as amostras 15, 30 e 115. Entretanto, isto torna-se especulativo, considerando-se o padrão de entrada de areias ao longo do mo the norte, indicado por outros dados analiticos.

o restante das amostras deste grupo é sugestivo de uma deriva de sedimentos fluviais para o estuário, incrementando o banco em formação na altura da amostra 55 .

o grupo d aproxima amostras marinhas $(5,6,7,16$ e 25), do ca nal do estuário $(73,66,60,48,42$ e 36), do saco da Fazenda (116 e 117), dentre os espigões do molhe norte (109, 110, 111, 112, 113,114 e 123) e do banco arenoso defronte à bacia de evolução $(59,62,68)$.

Esta situação parece refletir, de início, a já mencionada simi laridade entre sedimentos finos da corrente costeira e os sedi mentos transportados em suspensão no estuário. o limite princi pal da deposição desses sedimentos poderia ser colocado a montante da amostra 73 (limite a montante da ārea de ocorrência do grupo d).

E bastante significativa a aproximação que este grupo propõe para as amostras que os espigões do molhe norte (região de de cantação de material estuarinol e as do banco arenoso defronte à bacia de evolução. Ela sugere que, embora as areias desse ban co possam ser derivadas de material fluvial conforme exposto 
anteriormente), ele recebe também uma adição de material tipica mente estuarino. Nessa linha de raciocínio, considerando-se a provável deriva fluvial do banco que se coloca à altura da amos tra 55, essá situação sugere que o material estuarino fino que se adiciona ao banco arenoso defronte a bacia de evolução, corresponde, em parte, à fração mais fina do material marinho que penetra ao longo do molhe norte.

A correlação de todas as amostras através do coeficiente de dis tância mostra duas grandes famílias (FIGURA 102), cada qual com vários grupos. Amostras de ambientes fluvial, estuarino e mari nho encontram-se nas duas familias, de tal forma que os resultados desta análise são ilustrativas da grande semelhança na composição mineralógica em amostras desses diferentes ambientes, não sendo portanto úteis do ponto de vista da interpretação so bre sua origem.

2. Resultados obtidos na campanha de 1983

a) Observações realizadas durante a amositragem

As principais observações de campo referem-se a āreas de exposi ção do embasamento prē-sedimentação atual, identificados por ocorrência de argilas muito rijas.

De montante para jusante ocorrem áreas de exposição do embasa mento no entorno dos pontos 81,79 e 74 '. Com relação à campanha de 1982, nota-se uma redução nessas áreas de exposição do embasamento sedimentar mais antigo, situação sugestiva de seu entu彑 lhamento parcial por ocasião das cheias, quando maior quantidade de sedimentos seria transportada.

b) Classificação textural

A distribuição de fácies segundo a classificação textural de SHEPARD (1954, apud SuGUIO, 1973) é apresentada na FIGURA 103.

Segundo este critério percebem-se, para a região da plataforma,

- dois domínios distintos, com limite $\mathrm{N}-\mathrm{S}$, grosso modo alinhado à costa: um de areias, estendendo-se da praia até profundidades de 5-6 m, e outro de siltes e argilas, desde a barra do estuá rio até a parte mais externa da área amostrada na plataforma. As areias adentram o estuário para além da amostra 45, definindo provavelmente o limite de atuação da ägua marinha na movimen 


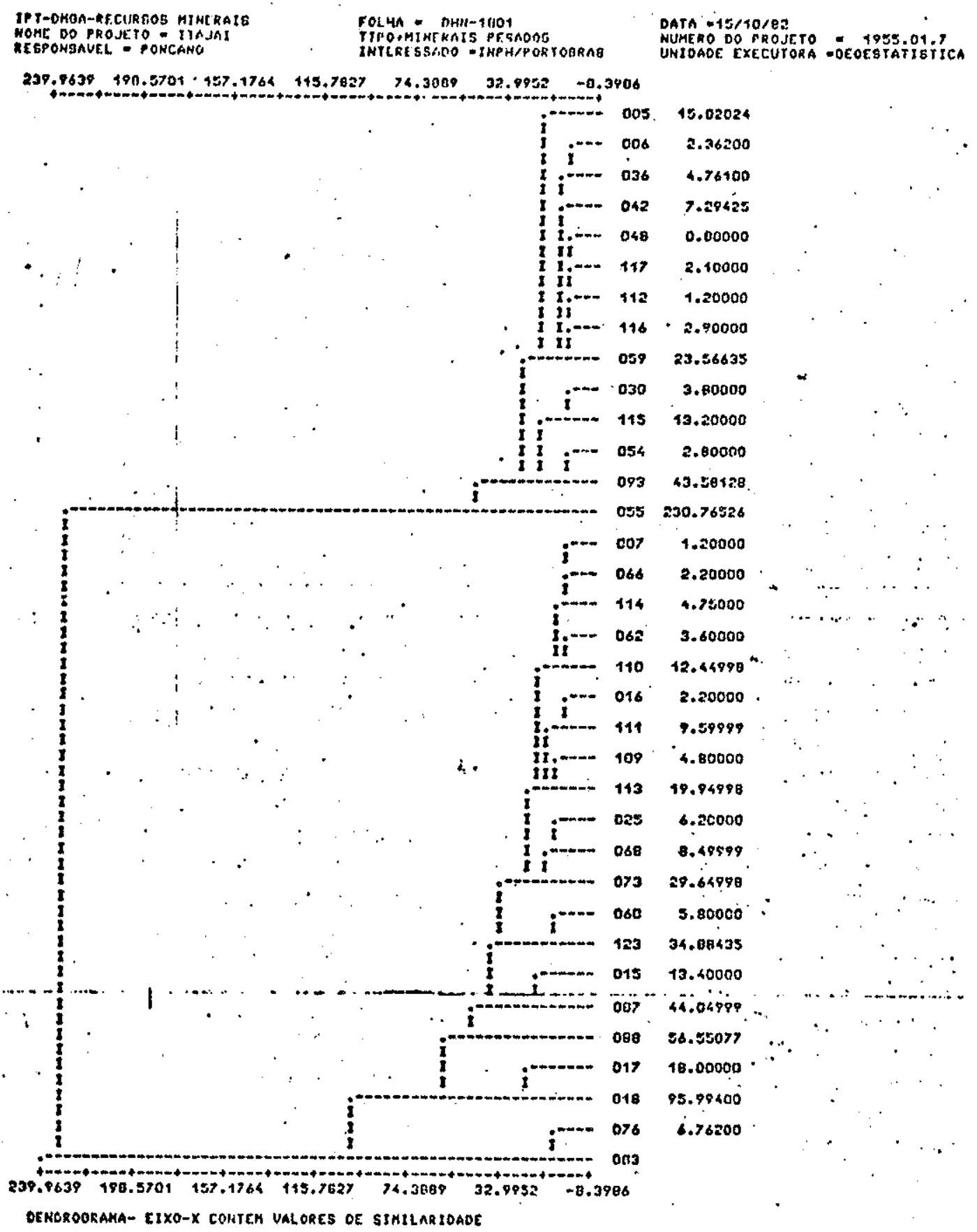

FIGURA 102 - Dendrograma segundo o coeficiente de distância para todas as amostras analisadas petrograficamente. 


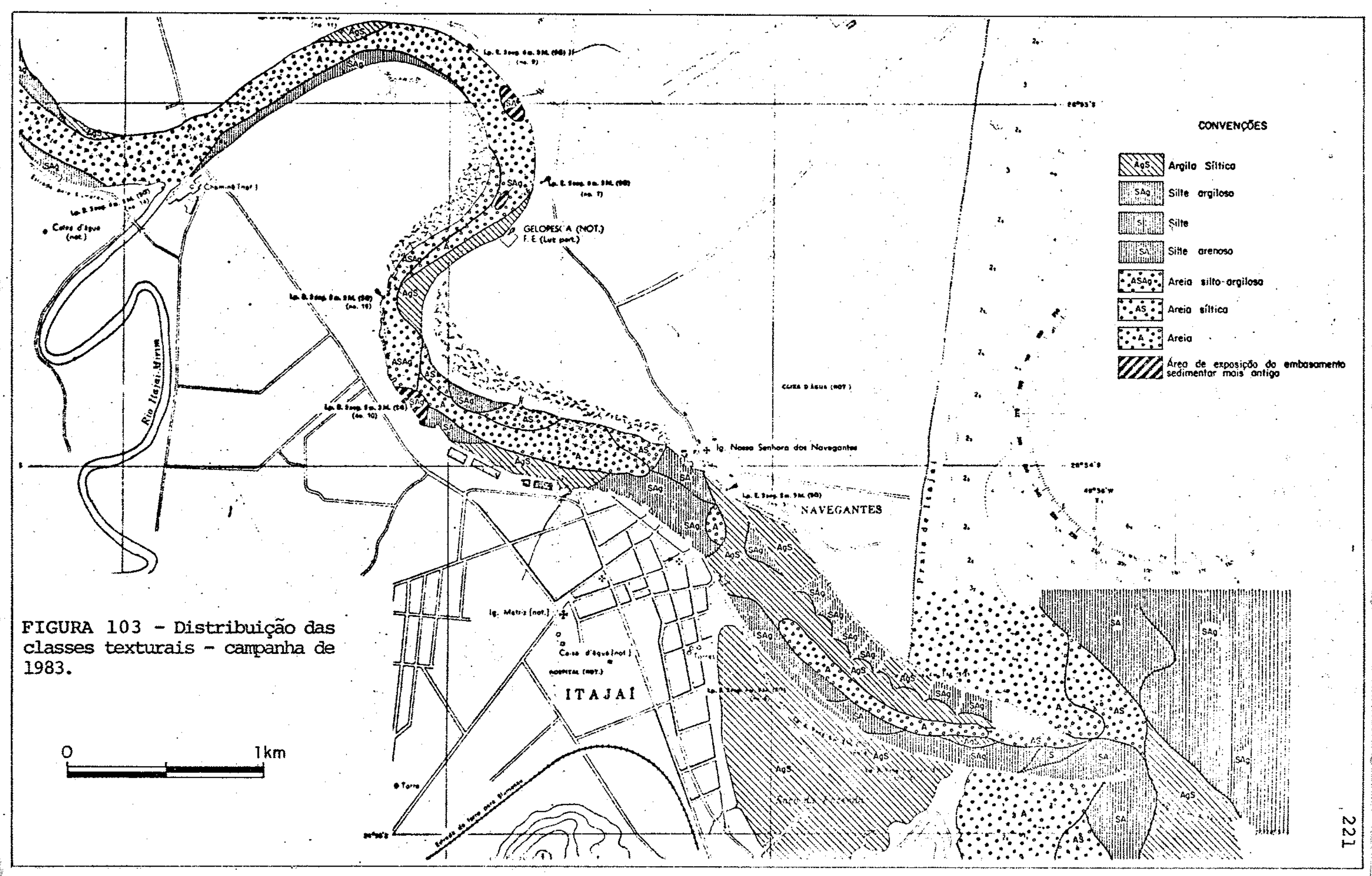


tação de sedimentos por arraste.

Os siltes da plataforma têm tambēm uma ligação com material si milar do estuário.

A situação que se configura é de penetração de material arenoso da plataforma ao longo do molhe norte, e saida de material fino do estuário, em faixa ao longo do molhe sul. Este material fino une-se, na plataforma, a siltes e argilas transportados ' por corrente próxima da costa ( que seriam, aliás, provenientes de outros cursos d'água que chegam à costa nessa região).

Por outro lado, o trecho mais a montante, ora investigado, entre as seções 93-94-95 e 59-50-61, caracteriza-se por predomínio de funcios arenosos e acumulação de siltes e argilas especialmente nas porções de margens convexas: Esta disposição obedece jã a um pa drão fluvial, com predomínio das condições de circulação de se dimentos pelo fluxo do rio.

Entre as seções 59-60-61 e 44-45-46 não hã um padrão definido , nem tipicamente dominado pela penetração marinha, nem caracte risticamente influenciado pela correnteza do rio.

c) Diâmetro médio

Nota-se que os padrões aqui obtidos (FIGURA 104) são essencial mente semelhantes aos anteriores (FIGURA 103), se bem que com re dução das porções arenosas, mais restritas ao centro do eanal do estuārio.

- alargamento da faixa arenosa na foz do Itajaí-Mirim é bastante sugestivo do aporte sólido dessa drenagem.

Ainda com relação às areias, é interessante notar, no baixo es tuārio, que a faixa arenosa entre as seções 32-33-34 e 44-45-46 não se acha diretamente ligada às areias da.plataforma, como no caso anterior.

Ademais hã que se notar um aumento da ărea em que não se pode definir claramente qual o processo de transporte dominante, se fluvial, se marinho. No caso anterior essa área parecia estar limitada pelas seções 59-60-61 e 44-45-46. Aqui, ela parece es tender-se entre as seções 44-45-46. e 65-66-67, abrangendo ja boa parte da bacia de evolução.

d) Distribuição das porcentagens de areia 


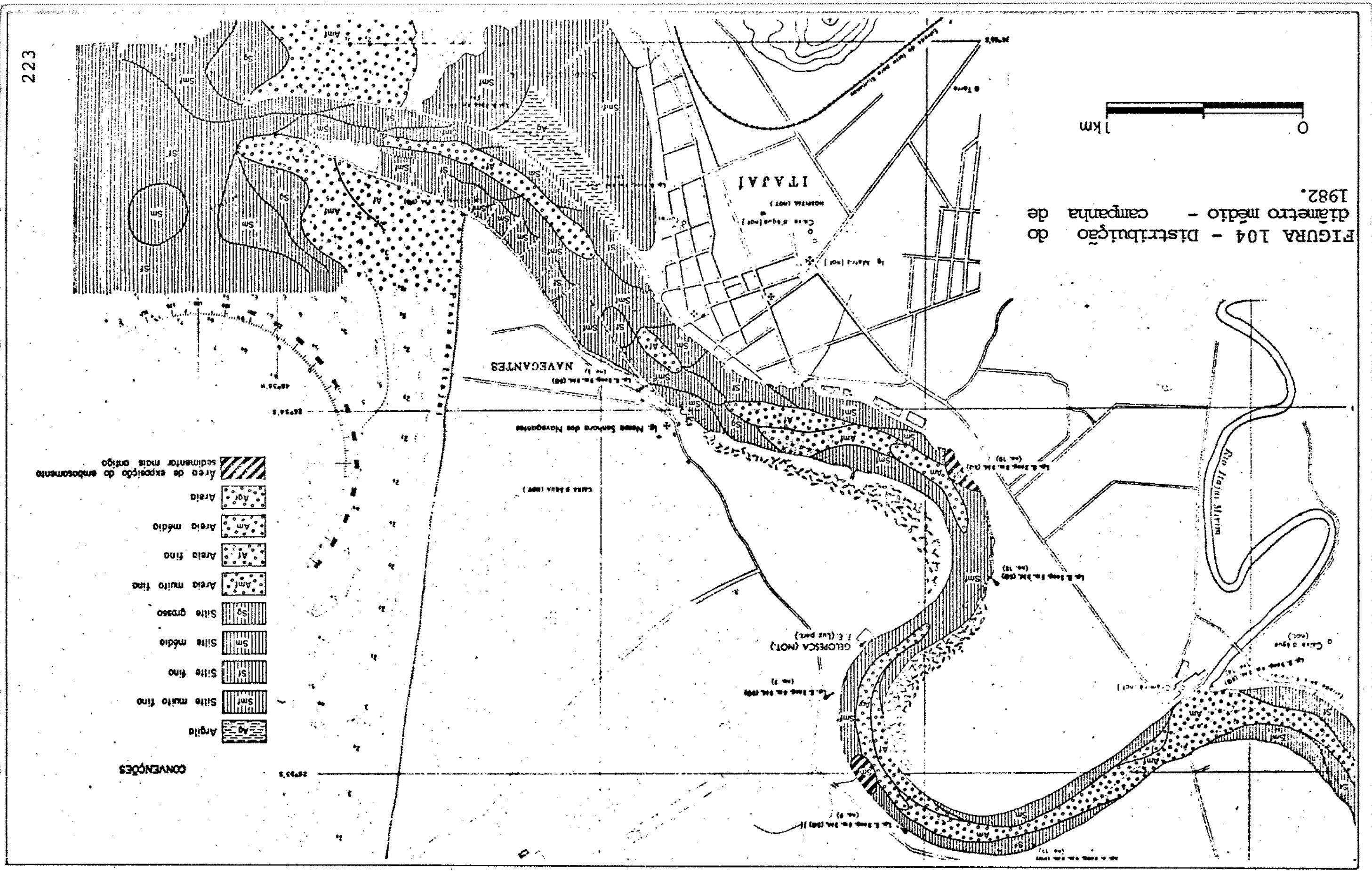


A avaliação da distribuição das classes granulométricas corres pondentes às areias (maiores que $0,062 \mathrm{~mm}$ prende-se aos dife rentes modos de transporte dos sedimentos arenosos e silto - ar gilosos.

Assim, embora as areias também possam ser transportadas em sus pensão, são predominantemente transportadas por arraste de fun do. Jā o material silto-argiloso é preferencialmente transportado em suspensão.

Dessa forma, o padrão de distribuição das areias (FIGURA 105), especialmente onde ocorrem em porcentagens elevadas, podem, au xiliar a definir as tendências de circulação de sedimentos es boçados pelos mapas de distribuição texturas e de diâmetros mé dios.

No geral, pode-se perceber, segundo este critério, os mesmos compartimentos definidos anteriormente.

Entretanto, a distribuição das areias entre o final da bacia de evolução (seção 68-69-70) e as proximidades da barra (seção 29-30-31) sugere que areias de proveniência continental possam ser transportadas mais a jusante da bacia de evolução (entomos da seção 53-54-55), eventualmente chegando ã faixa arenosa que começa próximo à seção 44-45-46. Esta fạ̣xa arenosa, que esta ria ligada à penetração de areias marinhas, conforme se expôs anteriormente, poderia então, em episōdios de maior descarga do Itajai-Açu, receber tambëm material arenoso, continental.

3. Variações temporais das. fãcies de superfície de fundo

As campanhas de amostragem de sedimentos de superficie de fundo de 1982 é 1983 referem-se a situações de descargas fluviais em torno de $250 \mathrm{~m}^{3} / \mathrm{s}$ e $750 \mathrm{~m}^{3} / \mathrm{s}$, representativas portanto das si tuações médias de cheia e estiagem, embora ténhamos que ressaltar - baixo significado das médias no caso do. Itajaí-Açu.

Comparando-se as duas campanhas atravēs da classificação tex tural, temos, no que se refere à plataforma, grande semelhança de resultados, com uma faixa de areias próxima à costa e uma faixa de siltes e argilas rumo ao mar, relacionada ao aporte de finos das drenagens da região, e do prōprio estuário do Itajaí-Açu ( FI GURA 106) .

Muito diversa è a situação no interior do estuário, em que, 


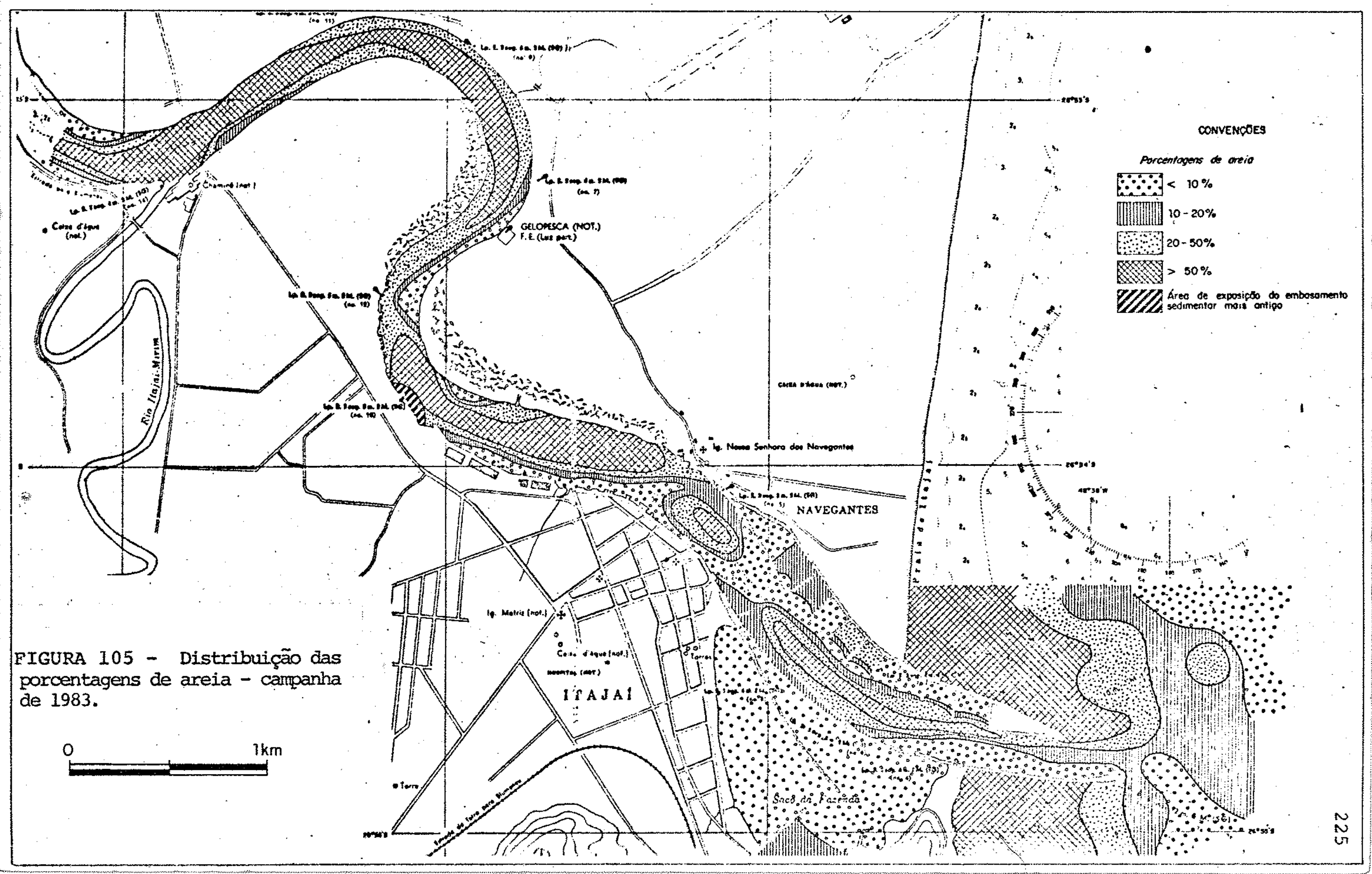



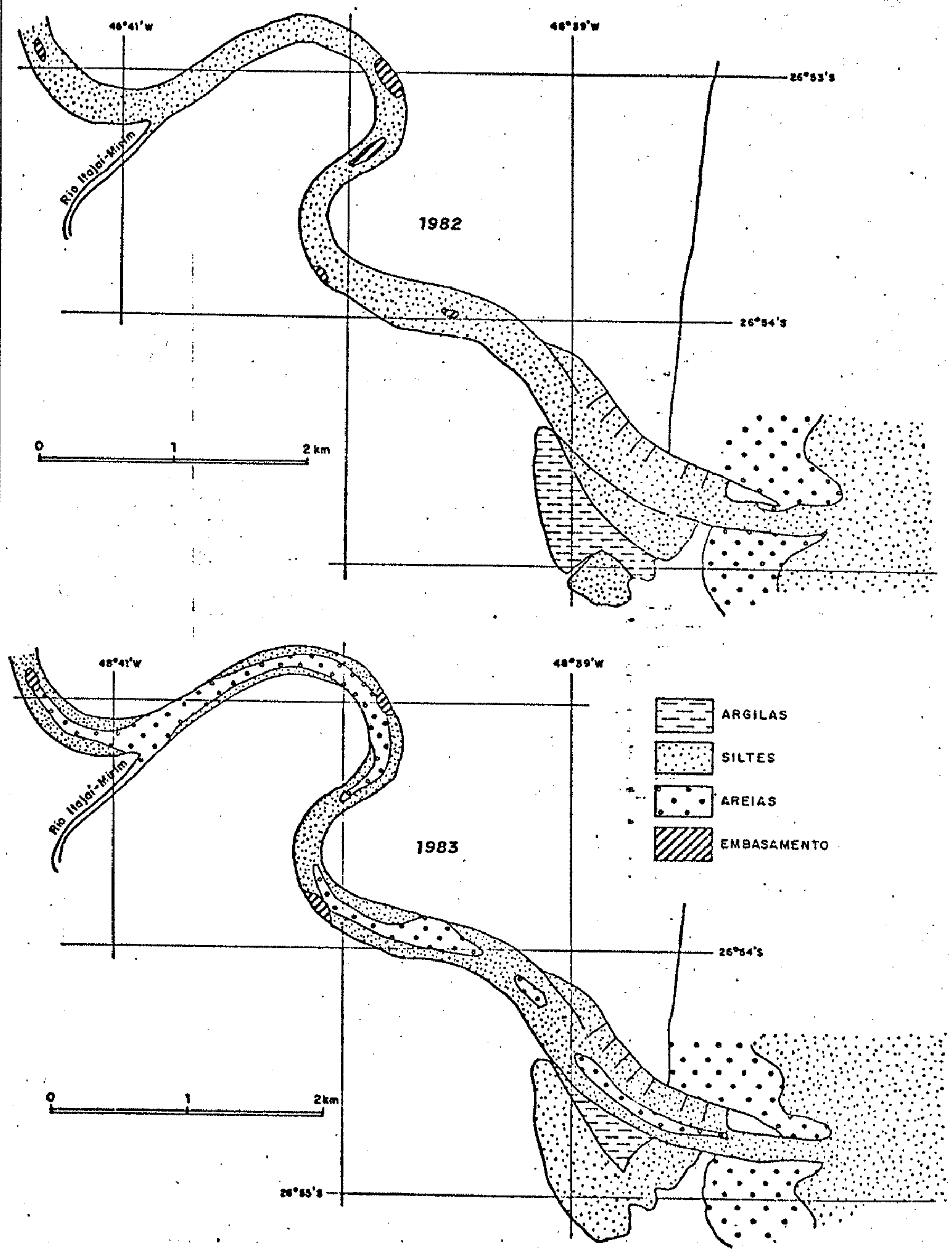

FłGURA 106 - Esboço da distribuição de diânetros médios dos sedimentos de superfície de fundo em 1982 e 1983. 
na campanha de 1982 tinha-se um predominio de argilas e siltes. Em 1983 são as areias que predominam do início da bacia de evolução (seção 59-60-6I). para montante, ocupando ainda uma expressiva área entre a seção 44-45-46 e a barra do estuário.

Essa mudança reflete bem a resposta sedimentar à variação de descarga do rio - cerca de $300 \mathrm{~m}^{3} / \mathrm{s}$ em 1982, em äguas baixas e. cerca de $700 \mathrm{~m}^{3} / \mathrm{s}$ em 1983, em äguas altas.

Aceitando-se, numa primeira aproximação, que a faixa arenosa do baixo estuārio representé o limite māximo de atuação da água marinha, no que se refere a sedimentos transportados por ar raste, teríamos um limite nas proximidades da seção 44-45-46.

Uma comparação, tendo por critērio as variações de diâmetros médios, reforçam as alterações verificadas acima, segundo mostra a FIGURA 106

Em 1982, pode-se dizer que o estuärio, acima da seção 32-33 -34 era domínio de siltes e argilas, ficando as areias quase que exclusivamente limitadas à plataforma.

Já em 1983 há faixas de areia descontinuas ao longo de todo - trecho amostrado no estuārio, que se interrompem, a jusante, pou co abaixo da seção 32-33-34. Esta situação é sugestiva de que ma terial arenoso de origem continental possa, em épocas de āguas al tas, depositar-se até bem mais a jusante da seção 53-54-55. Esta seção havìa sido indicada, na campanha de 1982 , como aịda representativa de tendência à deposição de material grosso na con vexidade do estuärio (entorno da amostra 55), disposição indicatị va de um fluxo fluvial importante.

A comparação dos mapas de distribuição das porcentagens de areia das duas campanhas mostra, mais uma vez, as mudanças ocorri das na superfície de fundo do estuärio, que passa a ser revestido, durante os períodos de águas altas, por sedimentos com altos teo res em areia ( FIGURA 107).

Conforme já se havia notado em outras ocasiões, a distribui ção de areias de 1983 é fortemente sugestiva de aporte de sedi mentos continentais atẽ a região dos molhes. o limite montante da faixa mais arenosa do baixo estuārio está prōximo ã seção 44-45 46, em concordância com a hipótese admitida no caso da classifica ção textural. 

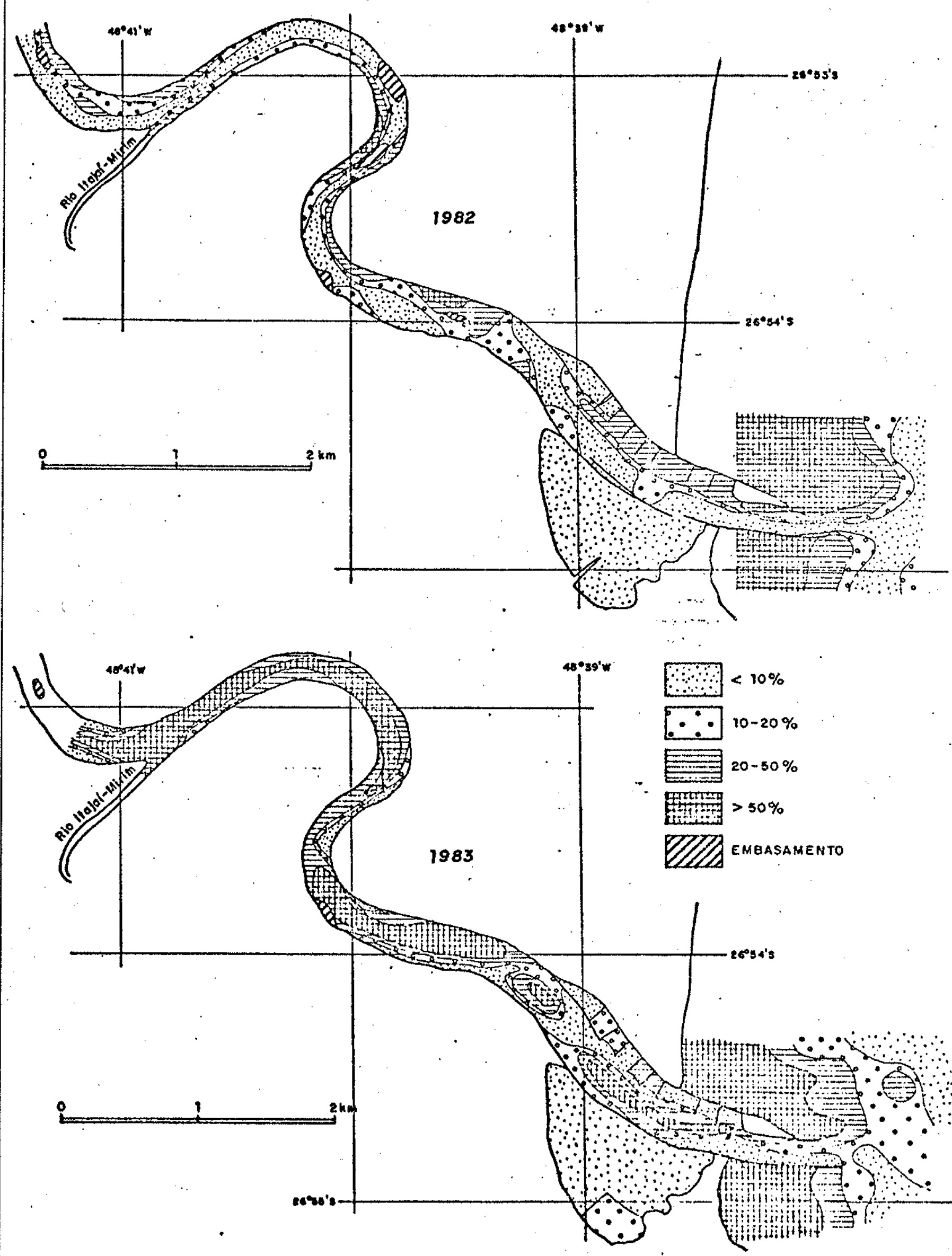

FIGURA 107 - Distribuição esquemätica das porcentagens de areia dos sedimentos de superfície de fundo em 1982 e 1983. 
Em vista porém da possibilidade de acreção de areias conti nentais, deve-se fazer reservas de que essa seção (44-45-46) repre sente a zona de influência de ägua marinha no transporte por arras te.

A distribuição por porcentagens de areia na porção terminal do estuärio, em 1982, sugeria que a influência da āgua marinha na penetração de material por arraste estendia-se até a seção 50-51-52.

Ter-se-ia então uma retração, por ocasião das águas alțas de 1983, em cerca de $450 \mathrm{~m}$ da água salina, para jusante, quando compa rada à situação de ăguas baixas de 1982 .

Levando em conta a possibilidade de transporte de areias flu viais para as porções mais baixas do estuārio, deve-se considerar que essa distância de $450 \mathrm{~m}$ pode ser uma estimativa conservadora.

Finalmente, como realizamos duas amostragens de sedimentos de superficie de fundo em 1983, uma em junho e outra em outubro ( FI GURA 82), podemos comparar as situações prévia e posterior às cheias excepcionais de junho-agosto.

A đistribuição de diâmetros mëdios em outubro de 1983 (FIGU RA 108) é muito semelhante à de junho de 1983 (FIGURA 104), mostrando apenas pequeno aumento em área dos fundos arenosos..

E preciso notar que essa comparação não pode ser rigorosa , pois amostramos em outubro metade das estações amostradas em junho. Adicionalmente, ressalvamos tambëm que a amostragem de outubro deu -se após dois meses da fase principal das cheias, e três meses apōs a cheia principal.

Levando em conta essas restrições, podemos considerar que a maior alteração das fäcies de fundo deu-se de 1982 para 1983 (FIGU RA 106), em função das prolongadas altas vazões do rio (exceto abril, sempre acima de $400 \mathrm{~m}^{3} / \mathrm{s}$ ). Um episödio de cheia catastrófica ( mé dia mäxima em julho, superior a $2000 \mathrm{~m}^{3} / \mathrm{s}$ l não parece ter altera do substancialmente a situação prévia.

E. Salinidade e material em suspensão

Estes elementos foram analisados a partir de amostras coleta das em 12 estaçōes, cuja localização é mostrađa na FIGURA 76.

1. Salinidade

Os valores de salinidade estão apresentados na FIGURA 109, e 


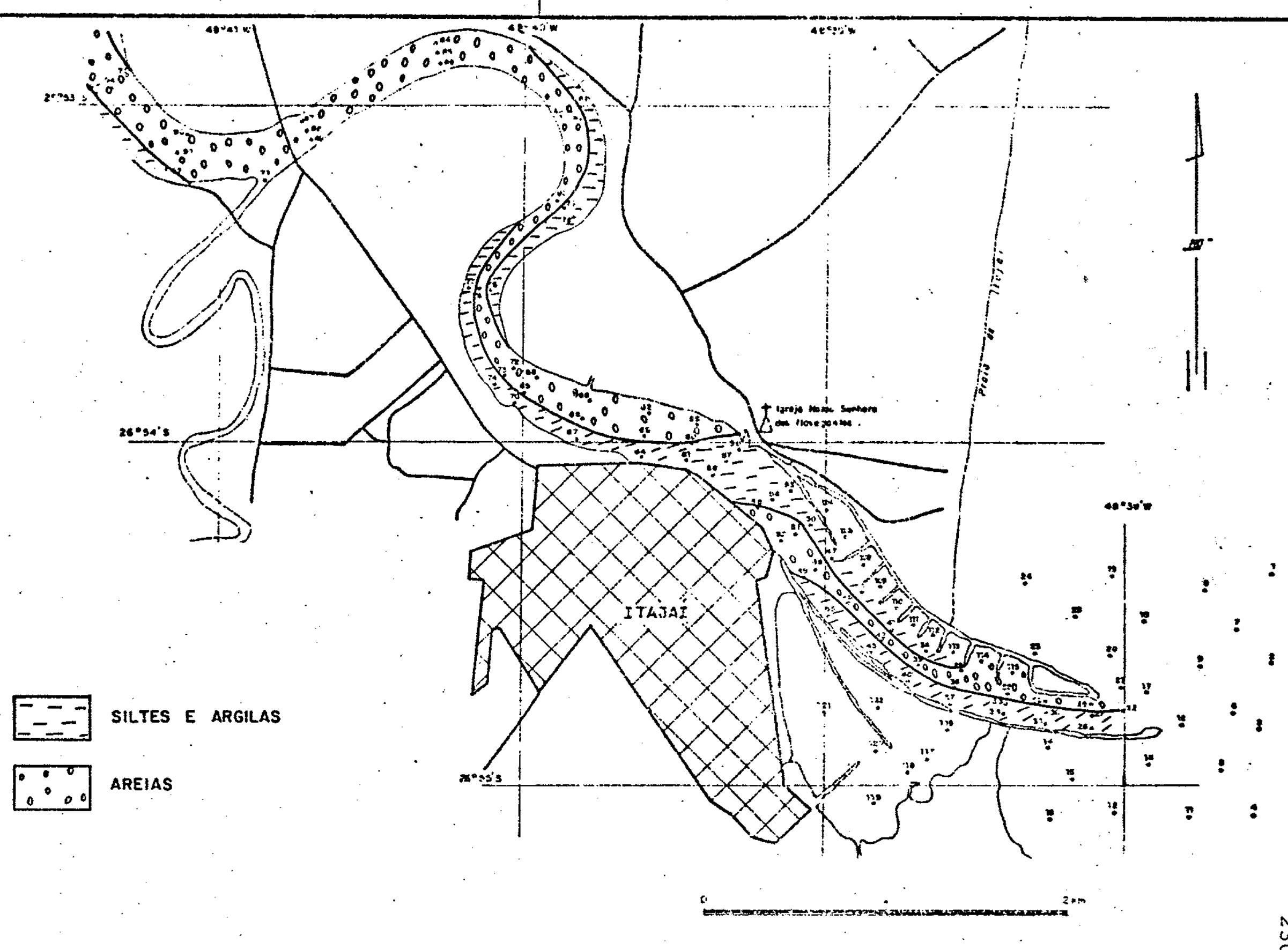

FIGURA 108 - Distribuição esquemătica do điâmetro médio após as cheias de 1983. 


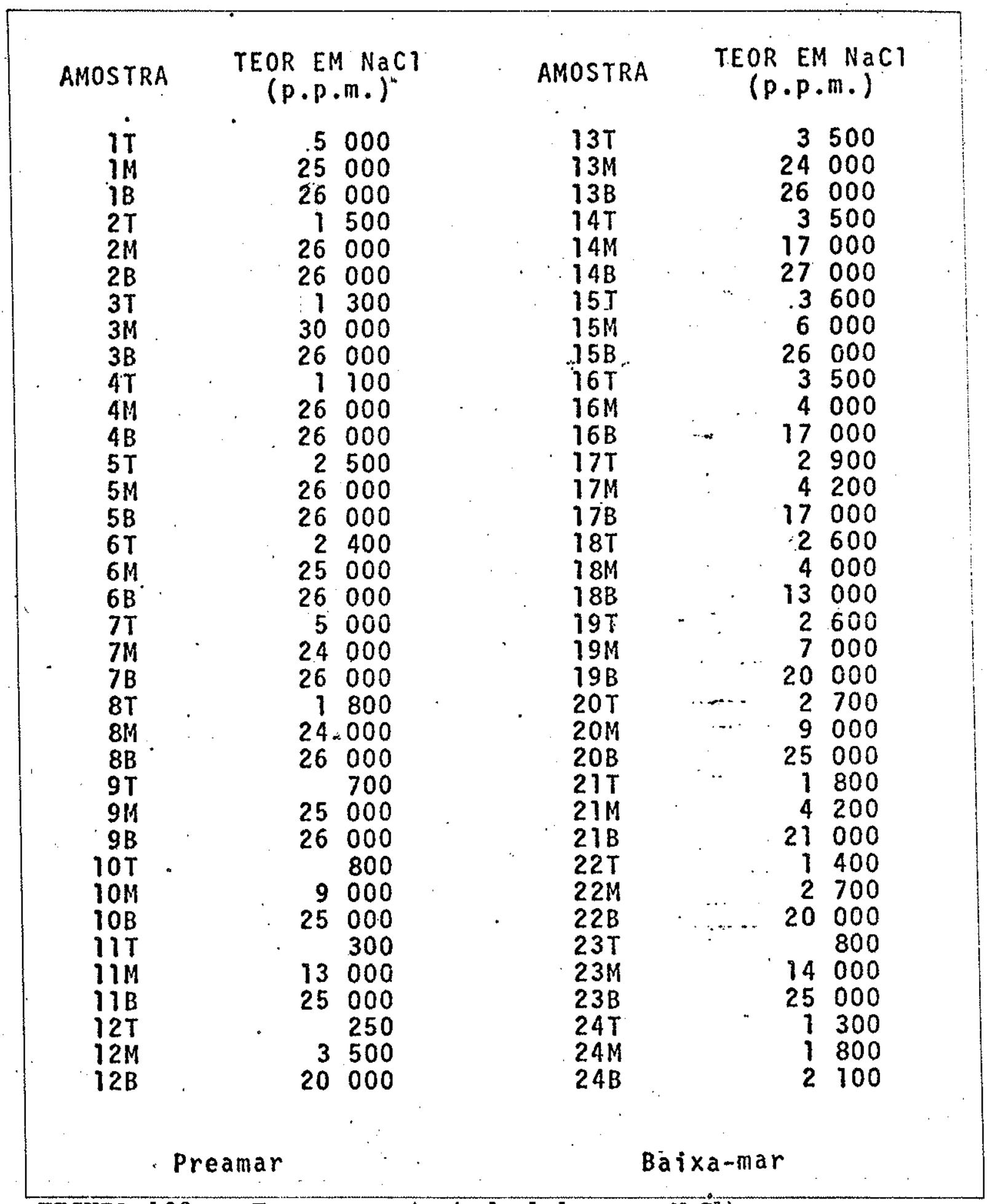

FIGURA 109 - Teores em sais (calculados para NaCi). 
sua distribuição espacial, em curvas de isovalores, na FIGURA 110 .

A situação de preamar, indica que toda a seção estudada do estuārio encontra-se 'sob domínio déágua salo bra ou salgada. Estas últimas apresentam valores mais baixos que os esperados para águas oceânicas; definem porém uma região de elevados teores em sais, com valores acima de 25000 p.p.m..

Ainda que de modo arbitrário, é possivel colocar uma separa ção de duas zonas de dominios de águas diferentes, passando pela curva de isovalores de 25000 p.p.m.. Isto configura, de modo su gestivo, uma cunha de água marinha até a altura da estação 11 .

Para a preamar, então, sob as condições de vazão investigadas, em torno de $250 \mathrm{~m}^{3} / \mathrm{s}$, próxima da vazão média do rio em estia gem, verificamos que água marinha penetra no estuärio acima da es tação 12, ou seja, acima da zona mäxima de influência marinha de tectada pela análise dos sedimentos de superfície de fundo, sob condições semelhantes de descarga fluvial.

Em baixa-max parece-nos possivel definir dois es tratos, limitados pela curva de 5000 p.p.m. Apesar de apresentar gradientes verticais de salinidade bastante similares ao longo de toda a seção, o estrato inferior mostra algumas irre gularidades, basicamente porções de āgua mais salgada no fundo, à altura das estações 8 e 11, alēm de uma nîtida configuração em cunha entre as seções 1 e 4.

2. Material em suspensão

As concentrações de sedimentos em suspensão são àpresentadas na FIGURA 111, enquanto que sua distribuição ao longo da seção amostrada encontra-se na. FIGURA 112.

A situação de preamar denota claramente uma zona de maiores concentrações associada à penetração da maré, com intensidade mâ xima até as proximidades da estação 9. O contato entre a zona de maiores e menores concentraçöes pode ser colocado na isocurva de $100 \mathrm{mg} / \mathrm{I}$, e configura uma cunha, sugestiva de um contato bem defi nido entre dois tipos de ăgua.

No caso da baixa-mar, hà que se notar que quase todos os valores se distribuem em faixas abaixo da última isocurva de preamar (de $40 \mathrm{mg} / 1$ ). A amostra 14B foi 


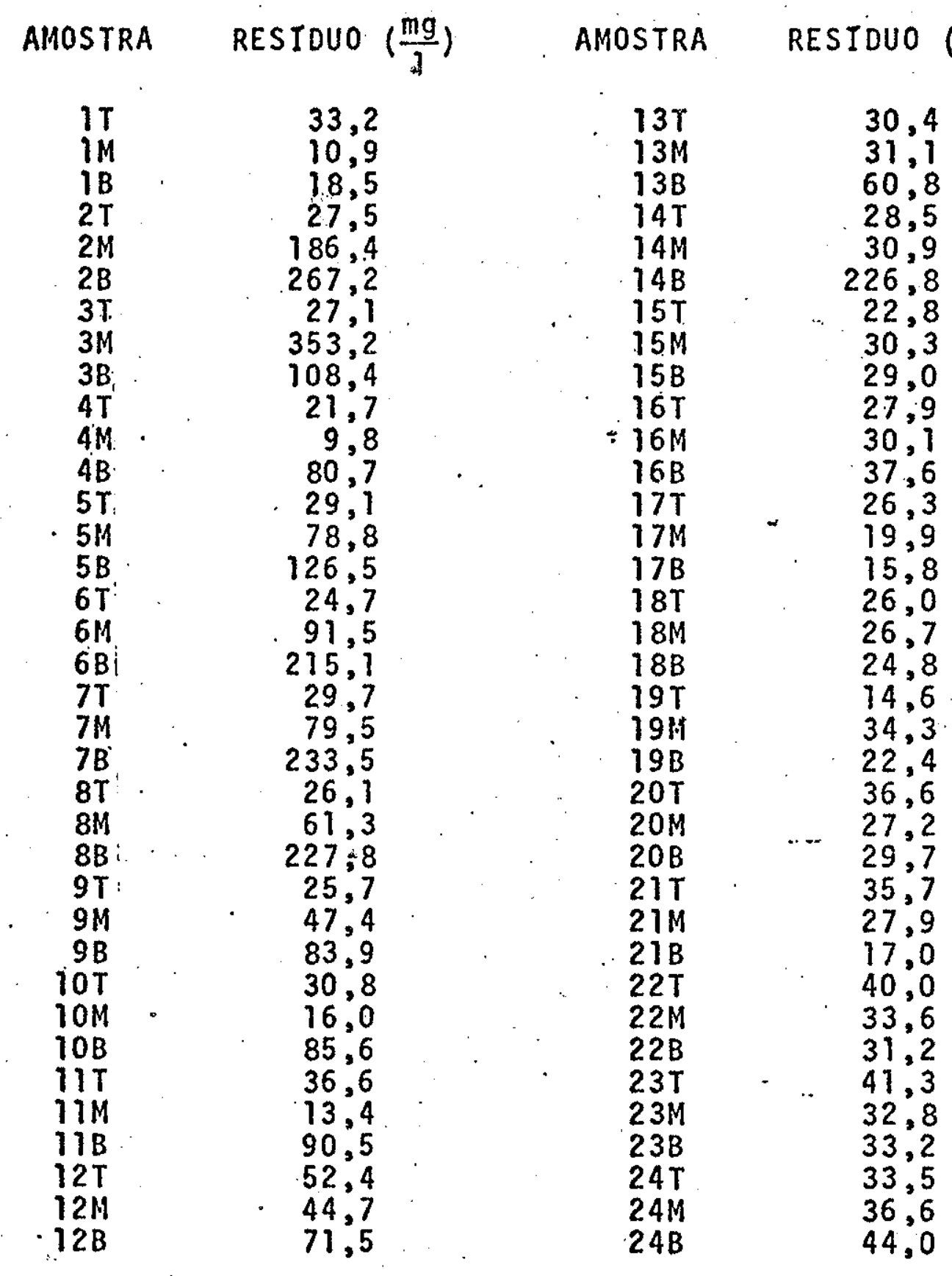

Preamar

Baixa-mar

FIGURA 111 - Concentrações de materiais sólidos em suspensão. 


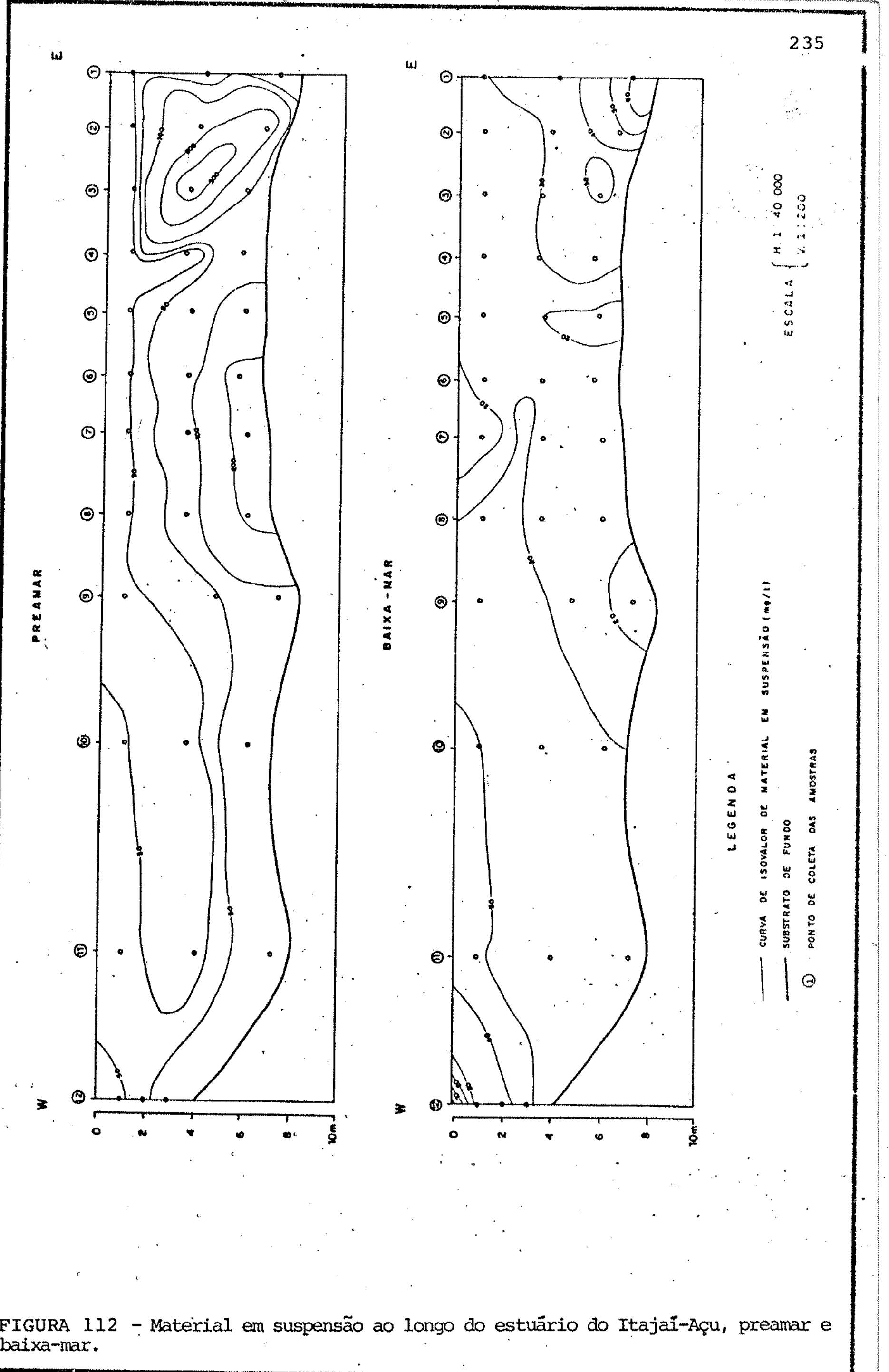


excluida deste tratamento por apresentar valor anômalo.

A partir de uma isocurva de $45 \mathrm{mg} / 1$, situada na desembocadu ra do estuário (estação 1), tem-se concentrações gradativamente me nores até $20 \mathrm{mg} / 1$, até pouco a montante da estação 9 . Entre as eș tações 9 e 12 há um ligeiro aumento nas concentrações, caracterizado pela curva de $35 \mathrm{mg} / 1$.

A disposição das faixas de isovalores de baixa-mar é suges tiva de mistura, na vertical, de parte das águas do estuārio.

Hä pois um grande contraste entre as situações de preamar e baixa-mar. No primeiro caso há uma marcação bem definida entre duas zonas diferentes quanto aos seus teores em sedimentos em sus pensão, enquanto que no segundo caso não há limites nítidos a des tacar.

Complementarmente, procedemos à caracterização granulométri ca dos sedimentos em suspensão em aparelho Coulter Counter. Anali samos os resultados assim obtidos pelo método de WARD (BOUROCHEV \& SAPORTA, 1982). O critério de agrupamento consiste em fundir as dúas ciasses em que a inércia é menor, o que equivale a reunir as duas classes mais próximas, tendo como distância entre elas a per da de inércia em que se incorre ao agrupá-las.

A inērcia interclasse é definida como a média dos quadrados das distâncias entre os centros de gravidade de cada classe e o centro de gravidade total.

Para compor a matriz de dados de correlação, não seria pos sivel usar as 16 classes granulomëtricas, anteriormente defini das, já que, pelo fato de cada amostra totalizar $100 \%$ o determi nante da matriz resultante seria nula.

Decidimos então fazer a correlação a partir das primeiras classes granulomëtricas, ou seja, eliminando-se a classe 1,00 a $0,794 \mu \mathrm{m}$. Esta escolha prende-șe ao fato de que a classe 1,00 a $0,794 \mu \mathrm{m}$ apresenta numerosos valores nulos, e todos eles bem meno res que a primeira classe $(32,0$ a $25,4 \mu \mathrm{m})$.

A correlação foi feita separadamente para preamar e baixa-mar, levando em conta a influência das velocidades de corrente na seleção das populações em suspensão (SENGUPTA, 1975, 1979).

os resultados obtidos estão apresentados nas FIGURAS 113 a 116. 


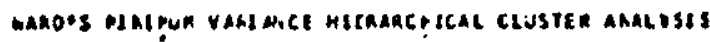

strme suatistics

\begin{tabular}{|c|c|c|c|c|c|}
\hline & MEM & 310 oev & skewness & ken cosis & Hruposity \\
\hline 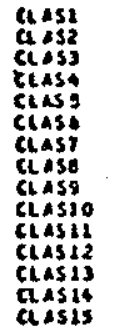 & 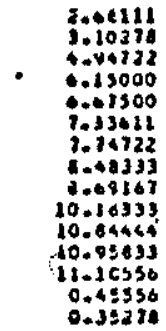 & 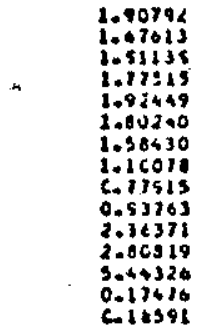 & 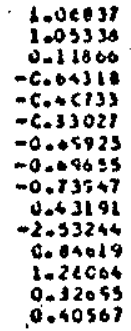 & 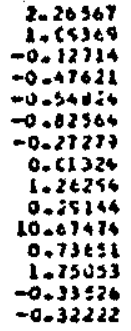 & 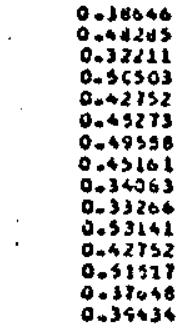 \\
\hline
\end{tabular}

EIGeAVALUES C* iHE covarbance katrix.

\begin{tabular}{|c|c|c|c|}
\hline IEENYLUE & OIFFE REACE & PHOPOS IICY & CUPULATIVE \\
\hline 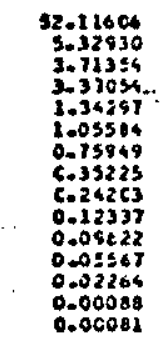 & $\begin{array}{r}46.78675 \\
1.01576 \\
0.34343 \\
2.02757 \\
6.26713 \\
0.25635 \\
0.40724 \\
0.11023 \\
0.13806 \\
0.02714 \\
c .04056 \\
8.03363 \\
0.62176 \\
0.00068\end{array}$ & 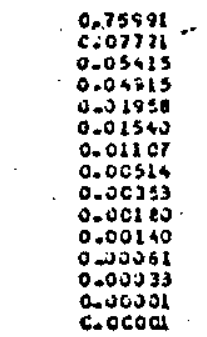 & 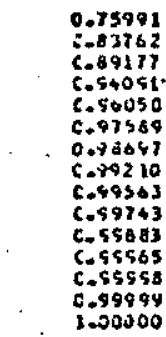 \\
\hline
\end{tabular}

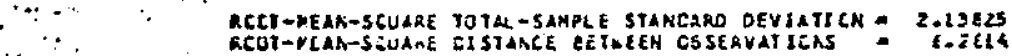

\begin{tabular}{|c|c|c|c|c|c|c|}
\hline $\begin{array}{c}\text { ALkEe } \\
\text { Cf } \\
\text { CListeas }\end{array}$ & $\begin{array}{l}\text { FRECUENCY } \\
\text { CF AES } \\
\text { CLUSTER }\end{array}$ & $\begin{array}{l}\text { RMS } 510 \\
\text { OF MEK } \\
\text { cLLSTEx }\end{array}$ & $\begin{array}{l}\text { SERI PART TAL } \\
R \rightarrow S C U A R E D\end{array}$ & F-SAUAREC & 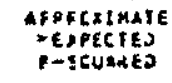 & $\begin{array}{l}\text { CUaIC } \\
\text { CLYSYERINE } \\
\text { CRIJERICN }\end{array}$ \\
\hline & $z$ & $\begin{array}{r}3.40143 \\
1.12341 \\
0 . t \leq 7 c 71 \\
1.17 t 11 \\
1.06111 \\
1.2512\end{array}$ & $\begin{array}{l}0.012273 \\
0.014369 \\
c . c 15343 \\
c .02 c 717 \\
0.024357 . \\
0.037251\end{array}$ & $\begin{array}{l}0.802334 \\
0.808028 \\
0.052443 \\
0.131706 \\
0.307+30 \\
0.770158 .\end{array}$ & 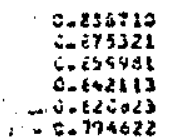 & $\begin{array}{l}-0.5438 \\
-0.5453 \\
-0.5298 \\
-0.0611 \\
-0.7753 \\
-1.0681\end{array}$ \\
\hline $\mathbf{z}$ & $\begin{array}{l}\text { is } \\
9 \\
28 \\
38\end{array}$ & $\begin{array}{l}2.10651 \\
10.4517 \\
1.45542 \\
2.03625\end{array}$ & $\begin{array}{l}\text { C.043221 } \\
0.009414 \\
c .115315 \\
0.542140\end{array}$ & $\begin{array}{l}0.720531 \\
0.037523 \\
0.542148 \\
0.000000\end{array}$ & $\begin{array}{r}c .700078 \\
c .767593 \\
6.360557 \\
0.600000\end{array}$ & $\begin{array}{r}-1.0173 \\
-1.0138 \\
-3.8254 \\
c .0000\end{array}$ \\
\hline
\end{tabular}

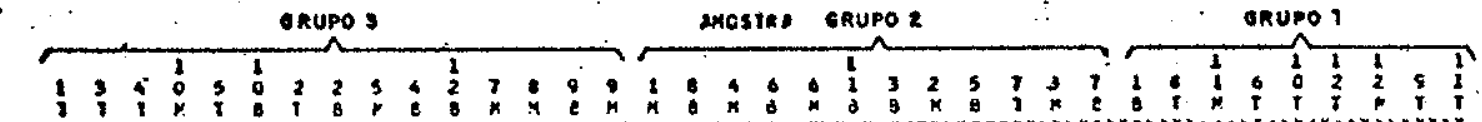

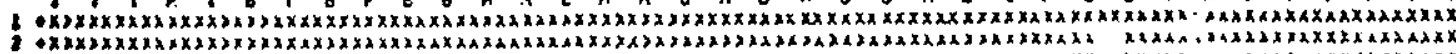

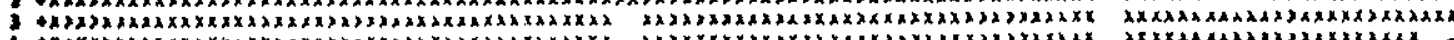

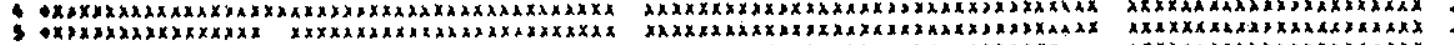

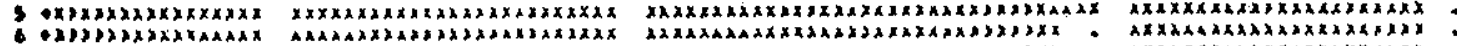

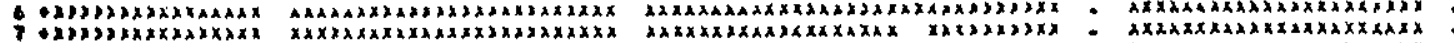

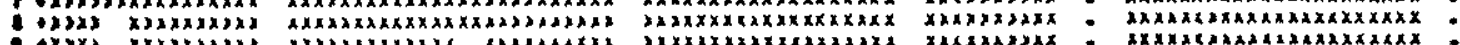

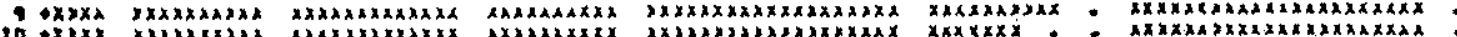

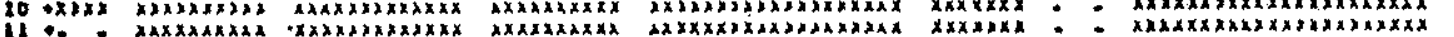

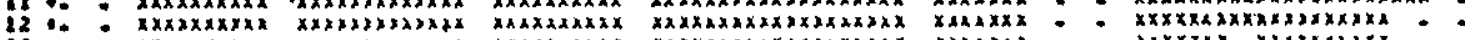

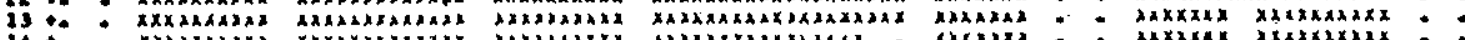

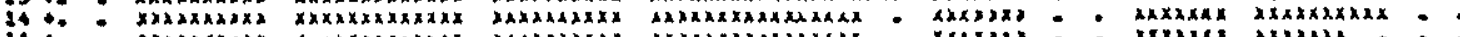

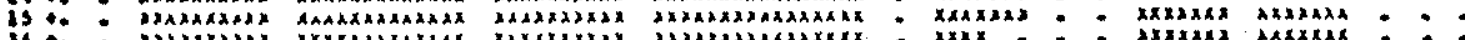

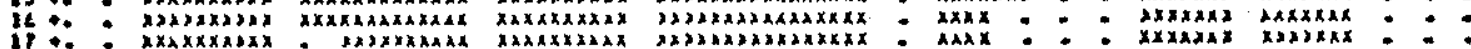

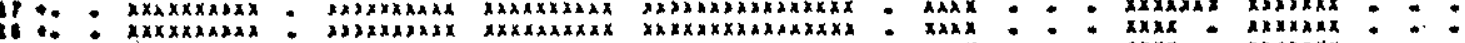

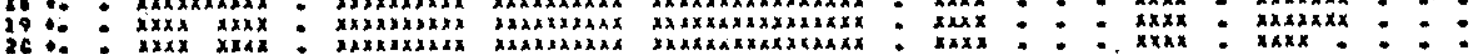

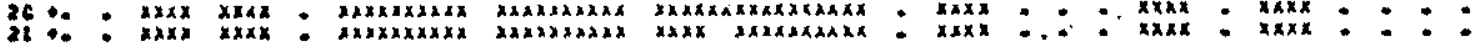

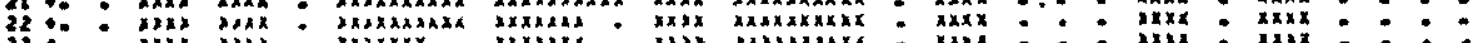

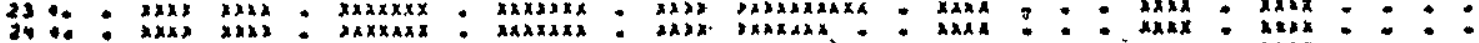

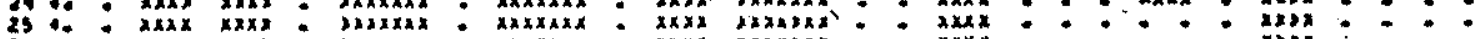

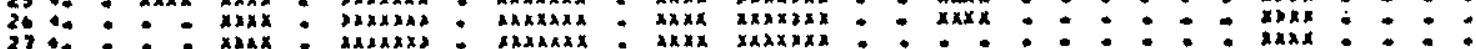

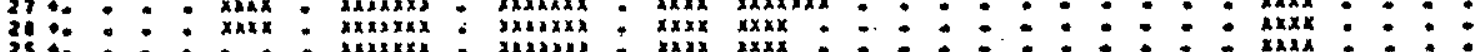

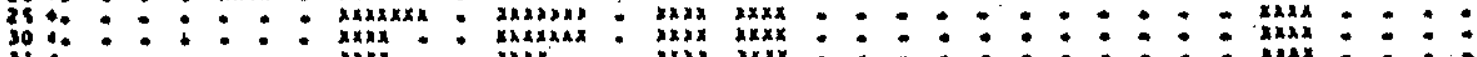

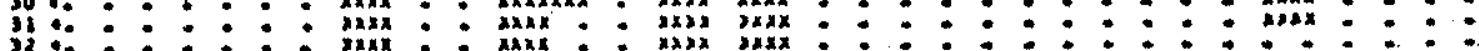

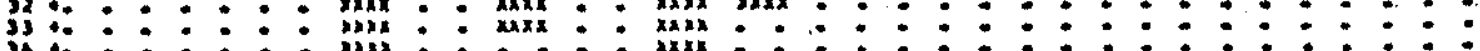

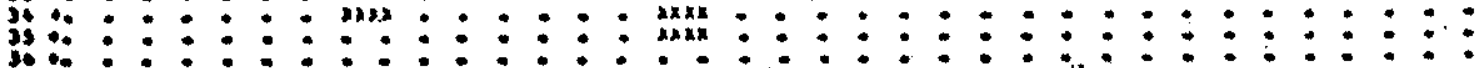

FIGURA 113 - Resumo dos cálculos estatísticos e gráfioo de agrupamento, mẻto do de iARD, para a preamar. 


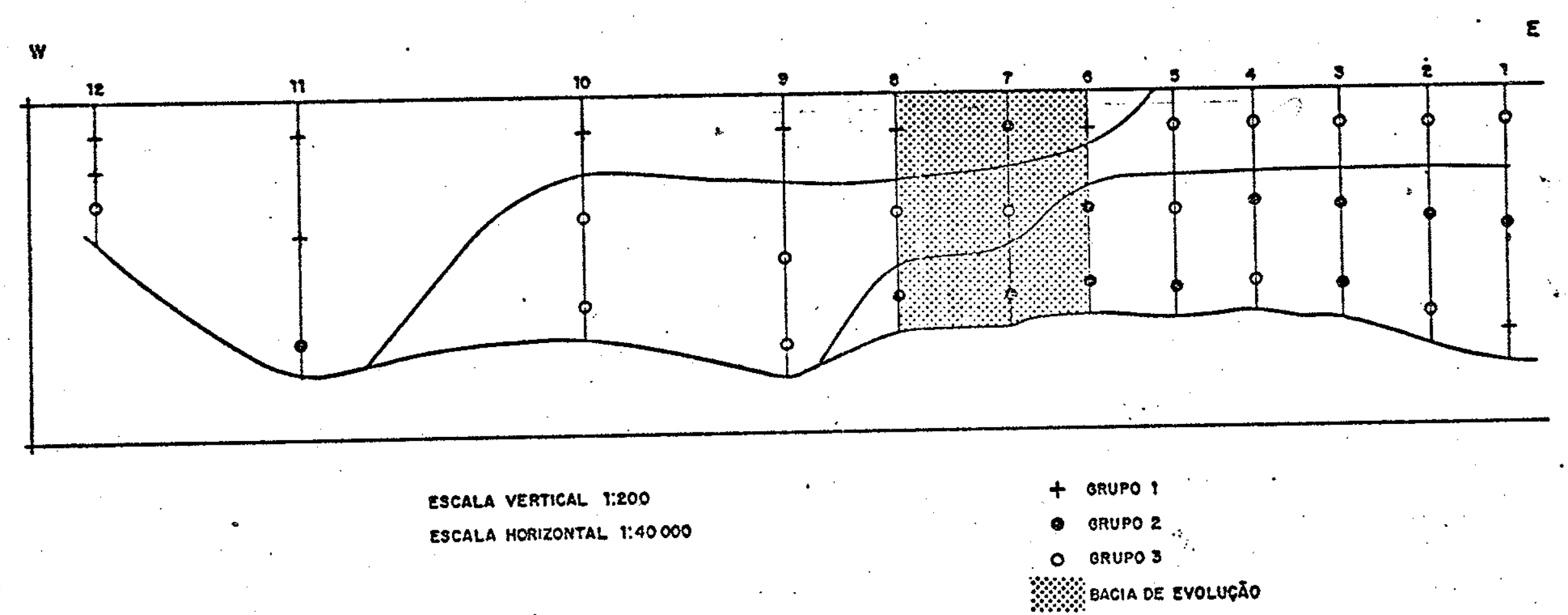

FIGURA 114 - Distribuição dos Grupos correlacionados segundo o método de WARD, para a preamar 
DARES MIKIRUK VAKIAAKE HICRAKCHICAL QUSIKE AKALYSIS

\begin{tabular}{|c|c|c|c|c|c|}
\hline & han & STO OEY & Sxe whe ss & URTCSIS & ofmoceltity \\
\hline 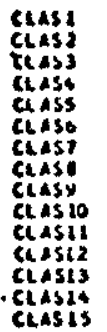 & 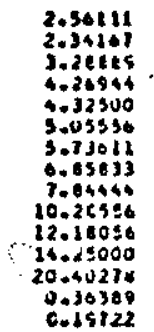 & 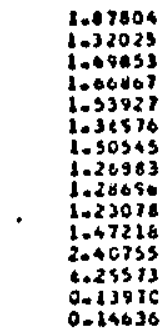 & 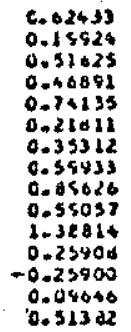 & 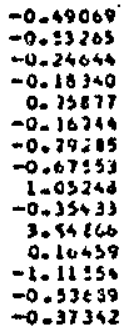 & 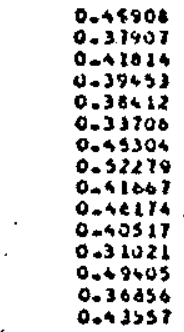 \\
\hline
\end{tabular}

ClCEnYalues of JHE Covariance katrix

\begin{tabular}{|c|c|c|c|}
\hline EICE AY ALUE & CIIFERENCE & PRCPCRIICN & CLMLLATIVE \\
\hline 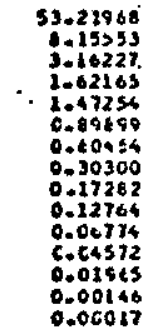 & 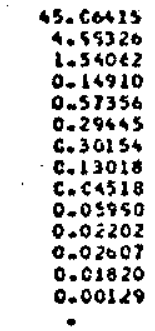 & $\begin{array}{l}0.46164 \\
0.11072 \\
0.04320 \\
0.02321 \\
0.021 c 7 \\
0.01267 \\
0.00263 \\
0.00436 \\
0.00247 \\
0.00183 \\
0.00047 \\
0.00045 \\
0.00028 \\
0.00002 \\
0.00003\end{array}$ & 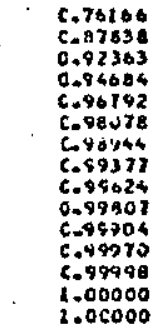 \\
\hline
\end{tabular}

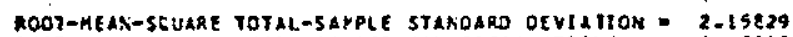

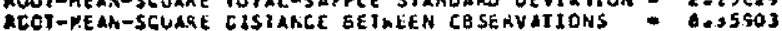

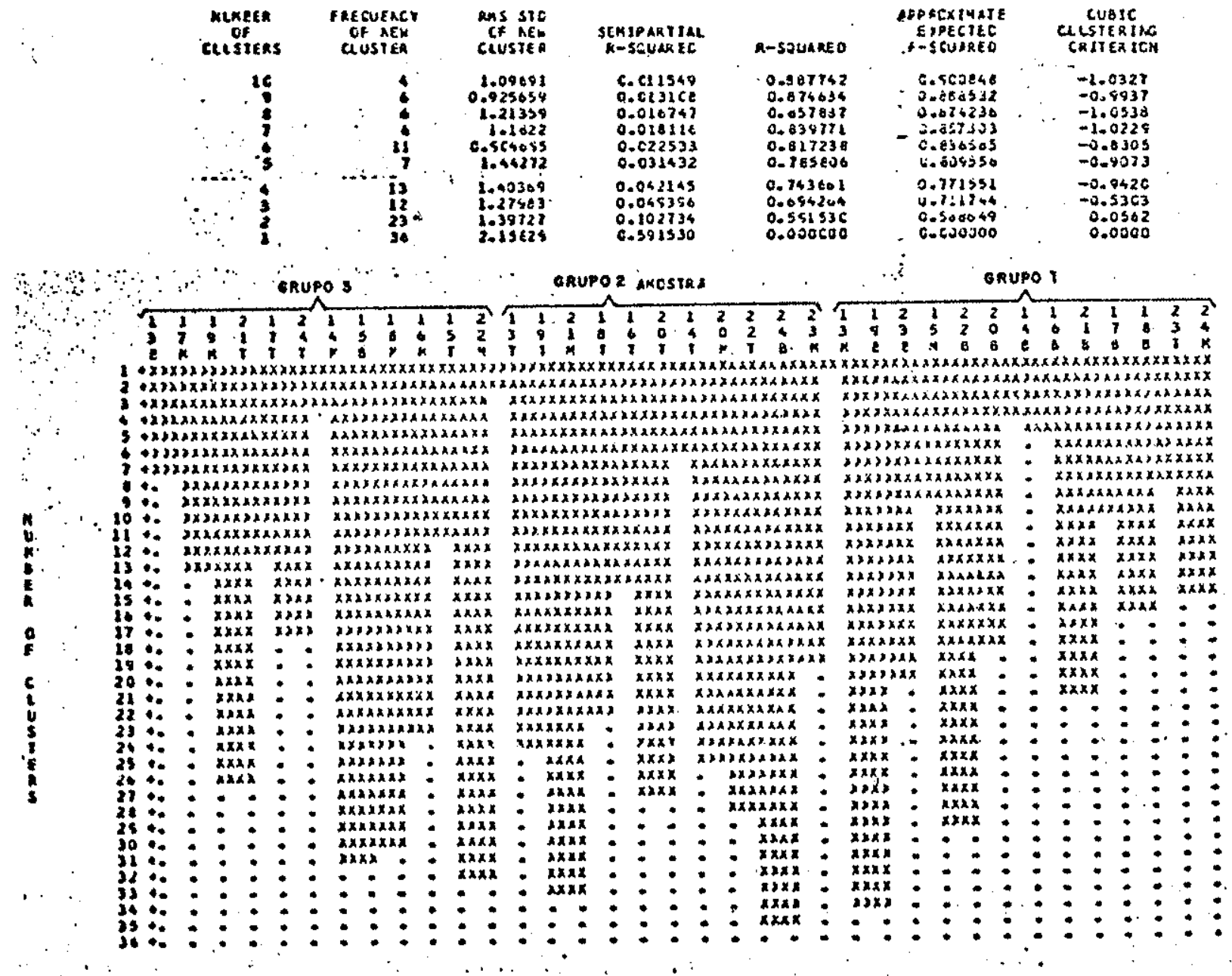

FIGURA 115. - Resumo dos cálculos estatísticos e grä́fico de agrupamento, méto do de WARD, para a baixa-mar. 


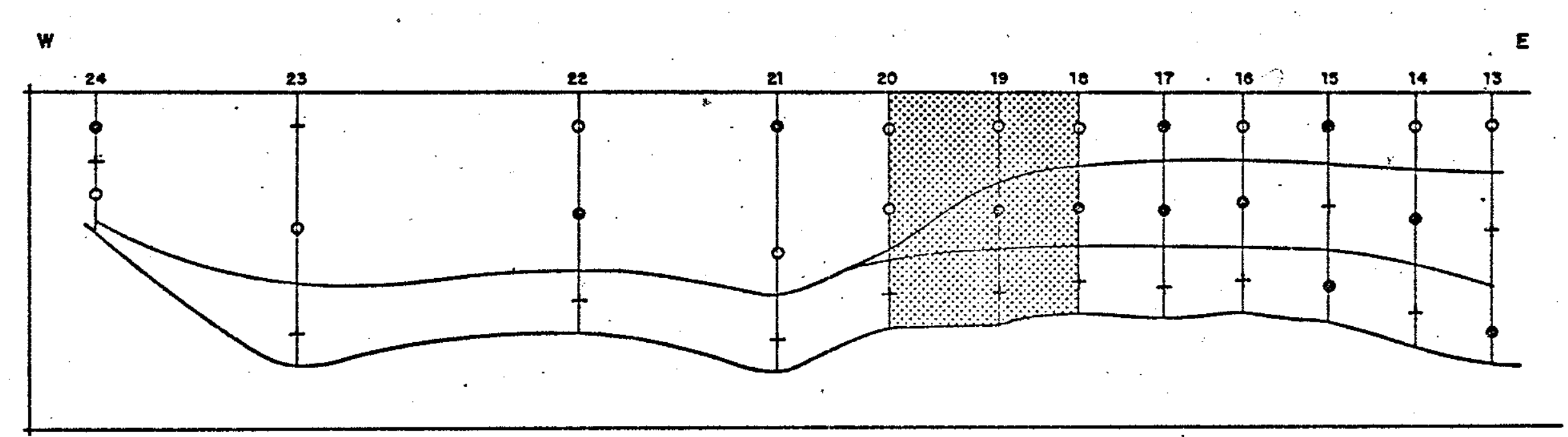

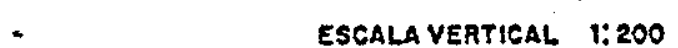

ESCALA HORIZONTAL $1: 40000$
+ GRUPO 1

- GRUPO 2

- GRUPO

FIGURA 116 - Distribuição dos grupos correlacionados segundo o método de WARD, para a baixa-mar 
No caso da preamar, foram estabelecidos três grupos, considerados significativos em função da distribuição de valores carac terísticos (eigenvalue) e de desvios-padrões (FIGURA 113).

os três grupos reconhecidos foram então distribuidoos segundo a seção amostrada (FIGURA 114), que foi dividida em áreas de predominância de cada um dos grupos. O resultado obtido é muito sugestivo da existência de uma população de sedimentos característicos da desembocadura do estuário (Grupo 2), de uma população característica de montante (Grupo 1) e de uma população interme diāria entre essas duas (Grupo 3).

A distribuição dessas populações pode ser interpretada a partir da penetração de uma cunha salina: à frente do material transportado por arraste, ter-se-ia a seleção de duas populações (as dos Grupos 2 e 3 ) de sedimentos colocados em suspensão, segun do o modelo de SENGUPTA (1975 e 1979) e GHOSH et alii (1981). A terceira população (a do Grupo 1) poderia resultar tanto de uma diferenciação das populações anteriores, como receber, na sua fox mação, sedimentos diferenciados a partir de transporte mais carac teristicamente fluvial.

No caso da baixa-mar, usando-se procedimento similar ao aci ma mencionado (FIGURA 115), pode-se notar que hả uma população ca racterística próxima ao leito do estuário (dađa pelo Grupo 1) e duas outras acima desta (FIGURA 116).

Neste caso, o limite entre as populações caracterizadas pelos grupos 2 e 3 não é nítido, podendo permitir outras interpreta ções.

Essas situações são bastante sugestivas, segundo o critério ora empregado, de um comportamento assimilävel à penetração de uma cunha salina na preamar, e de uma estratificação bastante mar cada na baixa-mar, seguramente em duas faixas (talvez três) de ma teriais distintos em suspensão.

3 Correlação entre salinidades e teoreş de material em sus pensão

As correlações entre todos os valores de salinidade e mate riais em suspensão, para preamar e baixa-mar (FIGURA 117) mostram, basicamente, grande dispersão de resultados. Não obs tante, pode-se notar melhor estruturação em preamax que na baixa 

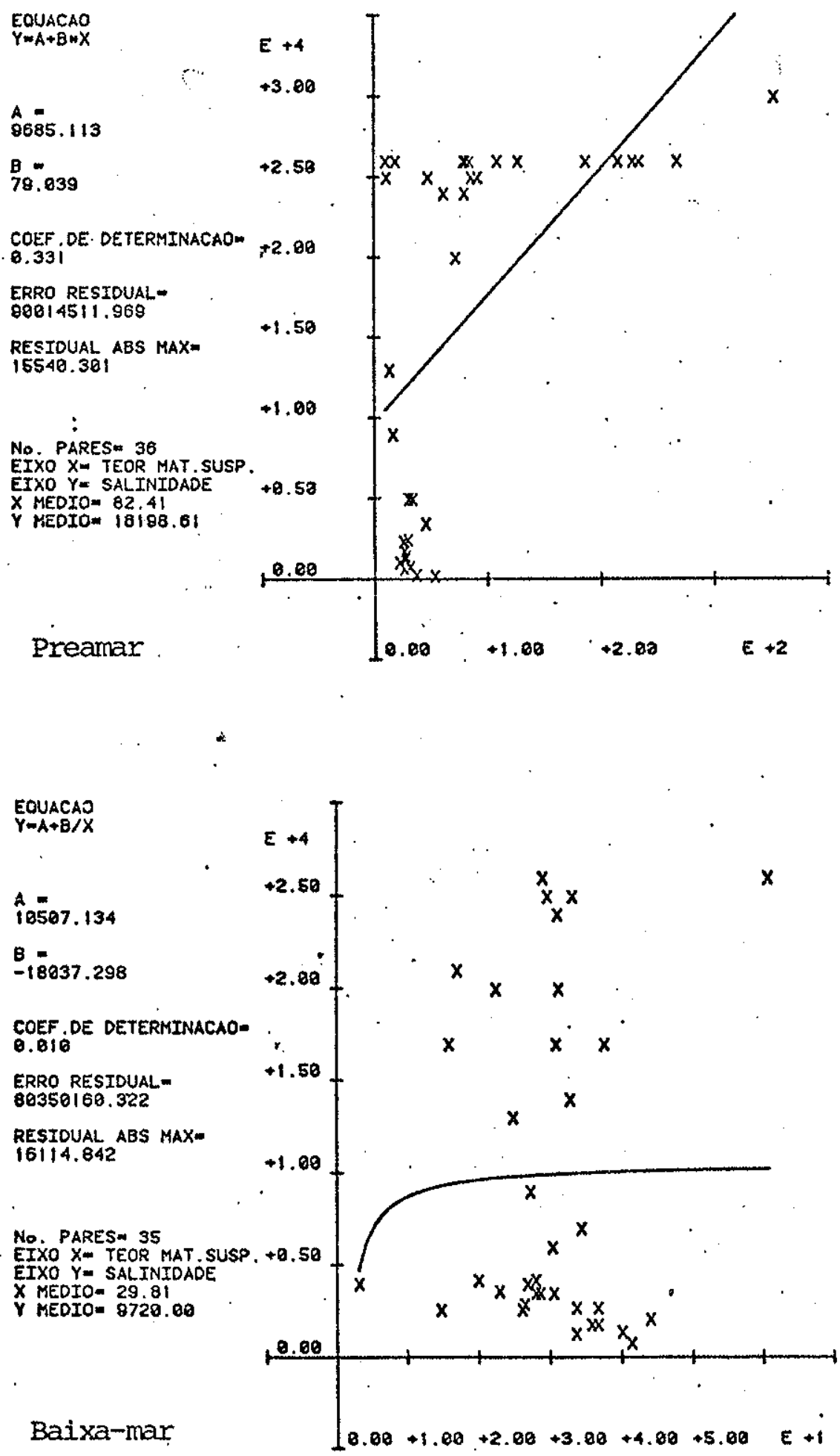

FIGURA 117 - Correlaçöes entre salinidade e teores de material em suspensão, para preamar e baixa-mar. 
-mar, em virtude de que procedemos a correlações parciais, visando estabelecer a que se poderia atribuir essa diferença.

As correlações abrangendo todas as amostras de base, meio e topo, forneceram os seguintes valores para coeficientes de corre lação: $0,19,0,46$ e 0,31 na preamar, $0,63,0,22$ e 0,0 na baixa-mar.

Desses resultados, apenas o caso das amostras de topo, na baixa-mar, forneceram correlação de algum interesse, embora com coeficiente baixo. A curva dessa distribuição (FIGURA 118) mostra que quanto menor a salinidade, maior o teor de material em sus pensão, situação sugestiva de que as amostiras de topo constituem uma camada de derivação fluvial.

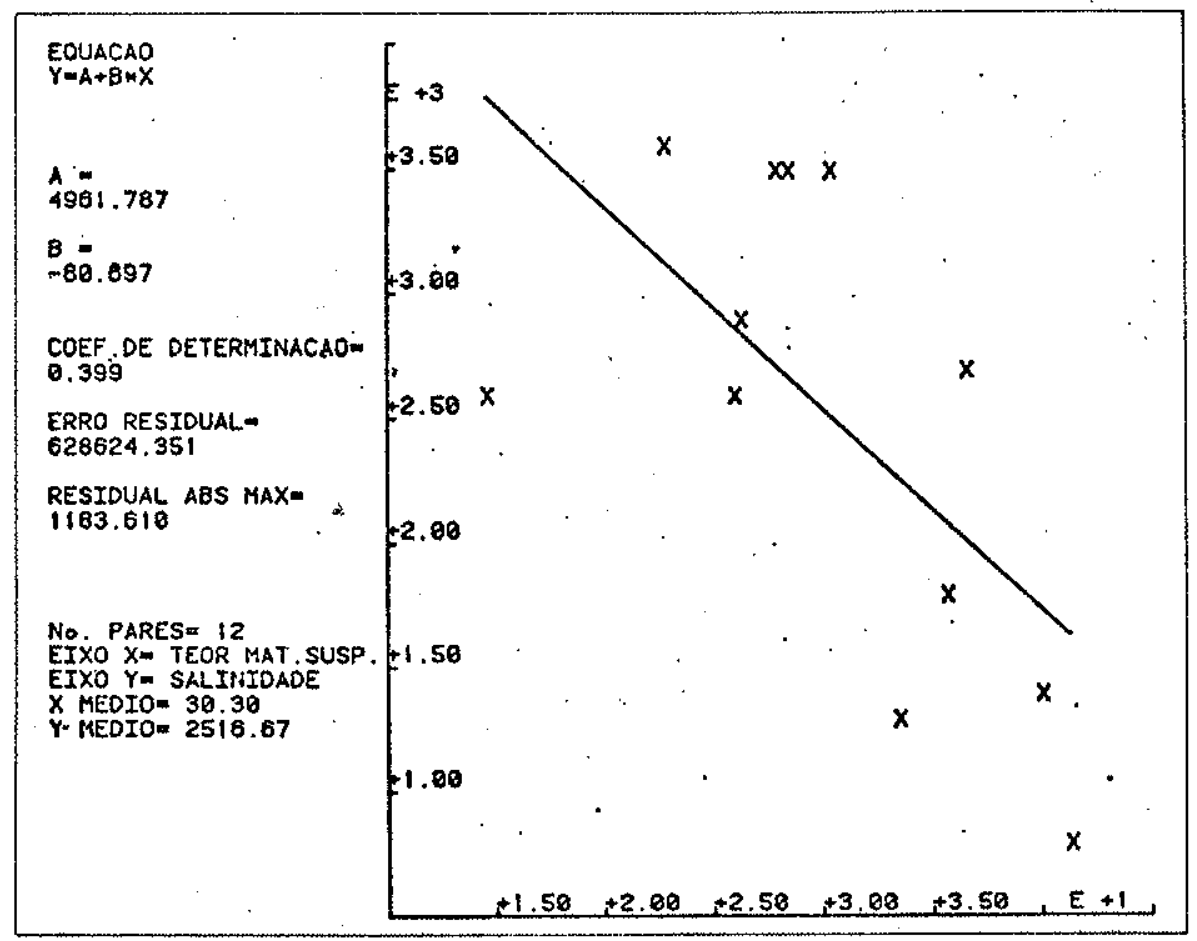

FIGURA 118-Correlação entre salinidades e teores de material em suspensão pa ra as amostras de topo na baixa-mar.

Procedemos então à correlação de salinidades e material em suspensão para as amostras de três conjuntos de quatro estações (1 a 4, 5 a 8 e 9 a 12), obtendo os seguintes,coeficientes de cor relação: $0,50,0,97$ e 0,69 na preamar, $0,59,0,01$ e 0,60 na bai xa-mar.

A elevada correlação observada no trecho entre as estações 5 e 8 parecia decorrer da posição da cunha de água salgada da preamar; estabelecemos então a correlação entre as amostras das 
estações 5 a 11, região onde a cunha está melhor caracterizada,obtendo entretanto um baixo valor de correlação, de 0,66.

F. Circulação estuarina

Não dispomos, para este caso, de medidas de velocidades de correntes no interior do estuário. Entretanto, parece-nos que a dịstribuição de salinidades e alguns elementos da anālise dos sô lidos em suspensão permitem propor uma classificação tentativa do estuārio do Itajaí-Açu.

Consideremos inicialmente a situação da salinidade na prea mar (FIGURA 110). Temos uma estratificação bem marcada, onde se po dem reconhecer, grosso modo, três gradientes verticaìs de salinidade: 1) na porção basal, entre as estações 1 e 11 , com peque nas variações de salinidades, todas iguais ou maiores que 25000 p.p.; 2) nas profundidades intermediárias de todo a seção levanta da, exceto a estação 12, com salinidades de 5000 a 25000 p.p.m; na verdade, este gradiente é acentuado entre as estações 1 e 9 , e diminui para montante; 3) na lâmina superior do estuário, com sá linidades inferiores a 5000 p.p.m..

Essa distribuição de salinidades não se enquandra a rigor em nenhum dos tipos bäsicos apresentados por BOWDEN (1967), pois apresenta conformação similar a um caso.de cunha salina, embora haja uam certa mistura entre ăguas doce e salgada.

Levando em conta que essa distribuição de salinidades repre senta uma situação de baixa descarga fluvial, acreditamos que o estuário em preamar, sob condições de mais alta descarga, passe a apresentar maior separação entre ãguas doce e salgada, aproximando -se mais tipicamente, então, do modelo de cunha salina.

$\mathrm{Na}$ baixa-mar (FIGURA 110) pode-se reconhecer basicamente dois estratos: um inferior, entre 5.000 e 25000 p.p.m., e outro supe rior, com salinidades menores que 5000 p.p.m., sendo o contato entre ambos muito irregular.

Neste caso, o padrão aproxima-se mais do tipo de estuārio es tratificado, com mistura vertical, embora possamos ainda reconhecer uma cunha mais salina entre as estações I e 4 .

Assim, no caso do Itajaí-Açu temos um estuārio em que a cir culação sofre grande influência fluvial, e que; na marē enchente, assi.ste ao avanço de uma cunha salina; as correntes de marê devem 
ser importantes, a ponto de provocar uma relativa mistura de água marinha e fluvial, descaracterizando então de certa forma esse mo delo. Na vazante, à medida que recua a cunha, vai-se implantando ao longo do estuário uma circulação em dois estratos, neste caso com maior mistura devido a correntes de maxé.

Nesse sentido, embora o material em suspensão não seja elemento classificatório, traz evidências que vêm de encontro ao es quema acima proposto. Assim, na preamar pudemos notar uma distribuição de diferentes populações compatível com a cunha salina (FI GURA 114) e com os dois estratos (FIGURA 116) na baixa-mar.

Esses dados, e mais a distribuição de sōlidos em suspensão (FIGURA 112) mostram zona de turbidez máxima entre as estações 1 e 9 na preamar, e entre as estações 1 e 3 na baixa-mar. As sim, a zona de maior turbidez está associada à posição da cunha salina.

Adicionalmente, podemos notar que os maiores teores absolutos de sólidos em suspensão associam-se a água salgada, e não a fiuvial. 
CAPITULO VI

\section{DISCUSSÃO DOS RESULTADOS}

\section{METODOLOGIA}

o ponto de partida metodológico deste trabalho postula que a disposição e dinâmica dos sedimentos atuais, que revestem e cir culam em corpos d'ägua costeiros, podem ser melhor compreeñicios se colocados sob a perspectiva da história geológica mais recente. Esta diz respeito, em especial, aos eventos quaternários relacionađos ao afeiçoamento da plataforma continental e regiões costei ras, e pode ser sintetizada a partir de dados geológicos e geomor fológicos.

As peculiaridades dessa evolução geológica mais recente fo ram sendo expostas em cada caso, e delas podemos relevar alguns as pectos.

o primeiro, e talvez mais importante, prende-se à última fa se de entalhe, cuja idade tentativa, correlativa da fase glacial whirm (cerca de 15.000 B.P.), foi inicialmente proposta para sepetiba, e a se guir generalizada para todos os caśos, com graus variados de incerteza.

Em decorrência, nossa suposição bāsica é a de que, ressalva dos aspectos tectônicos locais ou regionais, os estuārios e baías alojam-se em escavações resultantes de drenagens antigas, desenvolvidas há cerca de 15000 anos. Nos casos de Itajaí e de sepe tiba notamos a associação de partes mais profundas a locais de exposição de argilas rígidas, interpretando-as como embasamento. Raciocínio similar foi usado em outras áreas, sempre que se apre sentavam depressões mais profundas no interior de estuários e baías, mesmo que nelas não se contatassem afloramentos de aryilas do embasamento. E oportuno no tar que, de moảo independente, chegamos a conclusões semelhantes às dos pesquisadores da Bahia, sobre esta questão.

o segundo aspecto de interesse prende-se à transgressão flan driana, a cujo recuo associamos o desenvolvimento dos manguesais, especialmente a partir do stand stizl ocorrido há cerca de 2500 anos atrás. Este balizamento temporal auxilia a situar de modo mais preciso, no tempo, os fatores da dinâmica sedimentar, dos quais, os mais recentes são abordados atravês de documentação, 
imagens de sensores e amostragem.

Assim, uma vez estabelecidos os fatores de larga escala - no espaço - passamos a situar os eventos de sedimentação na escala dos milhares, centenas e dezenas de anos, aproximando-nos assim de intervalos de tempo compatíveis com os das vidas úteis de grandes. obras de engenharia, como são os portos.

os aspectos geológicos e geomorfológicos foram, no decorrer da exposição. abordados de modo bastante diverso, segundo a. área estudada, variando mesmo notavelmente em extensão. Essas variações representam na verdade um certo tateamento na detecção dos pontos mais importantes, que só vieram a ser melhor esclarecidos à medi da em que surgiam resultados de outras pesquisas, como, por exem plo, o intenso programa de datações C-14 desenvolvido em são paulo e na Bahia.

Procuraremos a seguir destacar alguns tópicos específicos que nos parecem os mais interessantes do ponto de vista metodológico.

A. Plantas e imagens de sensores

Em todos os casos abordados, lançamos mão de cartas topográficas, batimëtricas e imagens de sensores remotos, ña tentativa de caracterizar, através de dados qualitativos e quantitativos, as tendências mais recentes da evolução morfológica da ārea estudada.

Uso intensivo de cartas foi efetuado no caso de Guarás, quando mostramos a necessidade de se restringir as tēcnicas de comṕa ração mais rigorosa a edições resultantes de levantamentos compatí veis quanto à precisão. Naturalmente, esta constatação podia ser esperada, tendo em vista as mudanças tecnológicas dos ältimos cem anos, entretanto preferimos realizar todos os procedimentos passi veis de permitir a comparação de cartas da DHN com as mais antigas, conforme expusemos no CAPITULO 3 .

No que se refere aos produtos de sensores remotos, obtivemos bons resultados com fotos aéreas, também no caso de Guarás. As ten dências detectadas por fotos aéreas defasadas foram, então, ūteis na deteç̧ão e delimitação da evolução da linha de costa, cujos re sultados foram convergentes com os obtidos através da análise de cartas batimētricas.

Imagens de satélites da sērie LANDSAT foram usadas na avá liação do transporte litorâneo, e da atuação de correntes costei 
ras, nos casos de Itajaí-Açu, Santos e Baía de Todos os Santos. Nes tes últimos os resultados têm que ser tomados com reservas, uma vez que dizem respeito a apenas, um conjunto de cenas. No caso de Itajaî-Açu a pesquisa foi mais completa, embora deixasse ainda a descoberto um período do ano.

A deficiência acima apontada resulta da cobertura de nuvens, restrição que pode se tornar critica em determinadas regiões clima ticamente adversas. Temos porëm que destacar que a repetição de to madas de imagens em períodos curtos e compativeis com a maior par te dos processos costeiros, possivelmente mesmo com eventos excepcionais como tempestades, e a caracteristica que torna mais inte ressante o uso real e potencial - incluindo maior exploração de informações por sinais espectrais determinados - dos sensores ima geadores radiométricos em estudos de dinâmica costeira.

Alēm dạ questão ligada à disponibilidade de fotos aēreas e imagens de satélite, seu uso não é mutuamente exclusivo, devido a suas características próprias de resolução espacial (maior para as fotos aẻreas)e espectral (mais diversificada para os sensores ra diométricos

Assim, consideramos que as questões pendentes relativas a mudanças na morfologia e correntes costeiras possam ser resolvidas se empreendido um programa de pesquisa voltado para esse fim. Uma pesquisa desse tipo deveria equacionar não sö problemas regionais, mas também locais de circulação, tais como os apontados para a foz do Itajaí-Açu. Neste caso alguns avanços talvez só venham a ocorrer com a utilização de imagens de satélites da 3a. geração, de maior resolução geomētrica.

\section{B. Granulometria}

Uma discussão que perpassa todos os casos anteriormente apre sentados, exceto Guarăs, é o da interpretação dinâmica dos parâme tros estatisticos granulométricos, que ora retomamos.

Inicialmente, achamos importante filiar nossa interpretação ao trabalho de FOLK \& WARD (1957), no minimo pela utilização que fazemos das fórmulas por eles propostas. Nesse estudo, já referido no CAPITULO 2, são abordados sedimentos fortemente bimodais de uma barra fluvial constituida de areia e cascalho, distribuidos no in tervalo granulométrico de $-3 \phi$ a $+3 \emptyset$. Acreditam ter demonstrado, 
para esse intervalo, haver uma função entre os diversos parâmetros estatísticos, definida por um helicóide (FIGURA 5 ). Essa função seria continua para outros intervalos granulomētricos, sendo "ca da minimo de melhor seleção coincidente com uma moda do ambiente e cada máximo coincidente com uma posição intermodal ..." (FOLK \& WARD, 1957, p.24) (FIGURA 119).

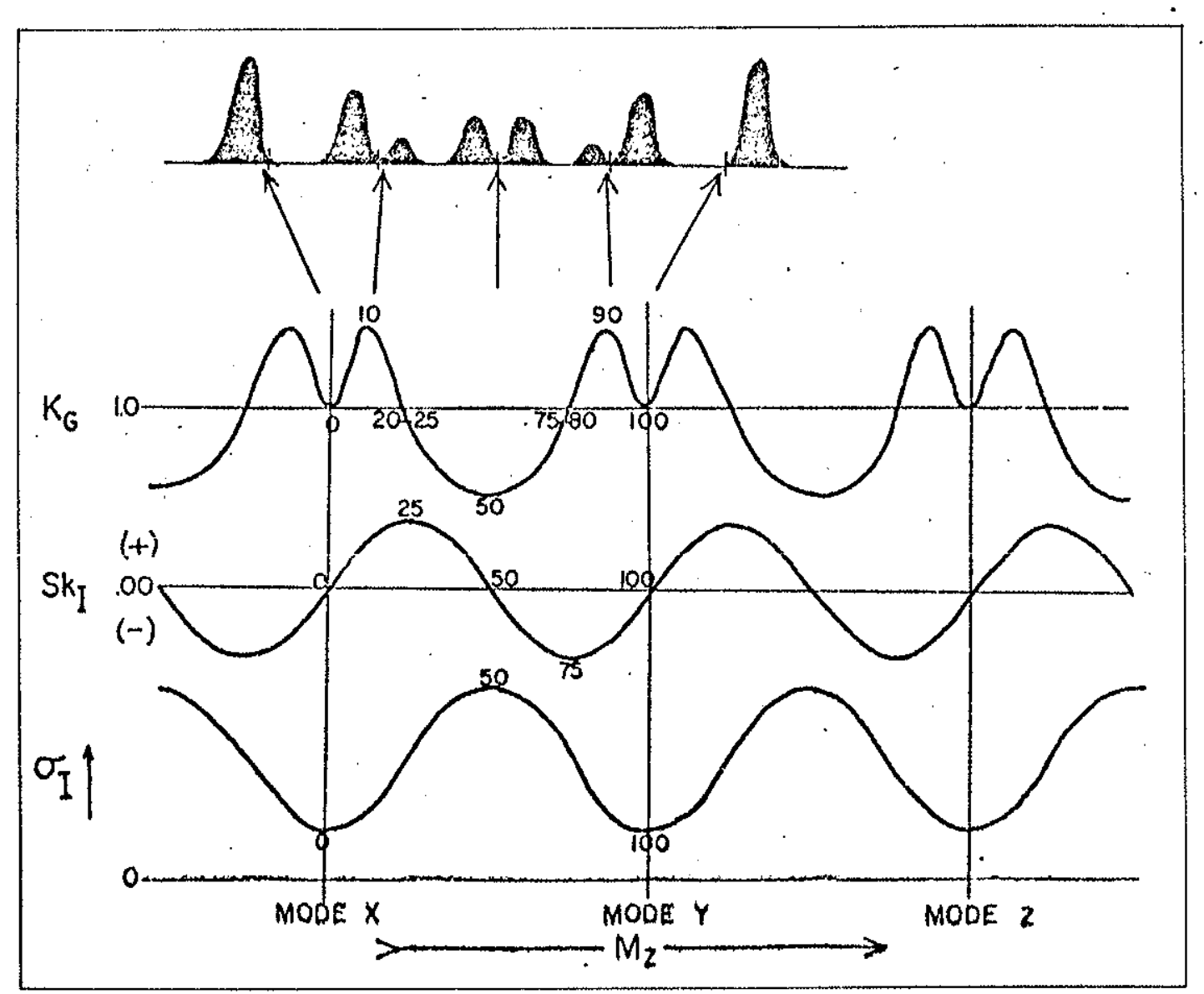

FIGURA 119- Variação teórica do desvio-padrão, assimetria e curtose em fun ção do diâmetro mëdio, para um sedimento hipotético polimodal (FOLK \& WARD, 1957, p.24).

Suas conclusões vão ainda no sentido de que pequenas varia ções de curtose e assimetria de seus valores normais são indicati vos de bimodalidade, enquanto que valores extremos de curtose po dem ser interpretados no sentido de que o sedimento . considerado guaraa caracteristicas de uma fase prévia, cujo meio foi mais efi ciente em promover seleção que o meio em que veio a ser depositado.

Finalizam com a observação de que maiores progressos na in 
terpretação devem ser esperados do estudo quadri-dimensional dos parämetros, mais de que seus valores absolutos.

SHEPARD \& YOUNG (1961) contestam o valor da assimetria como parâmetro interpretativo de ambiente. FOLK (1962) e DUANE ( 1964 ) não aceitam essa conclusão, atribuindo o insucesso dos primeiros autores ao método analítico, pois SHEPARD \& YOUNG (1961) realizaram análise em tubo de sedimentação, o que levaria a valores de assimetria sistematicamente negativos. DUANE (1964) acredita que as distribuições granulomētricas obtidas por tubo de sedimentação diferem das obtidas por peneiramento, não sendo vālido comparar resultados dessas duas técnicas.

DUANE (1964) realizou estudo em diversos ambientes da carolina do Norte, voltado à interpretação da assimetria. Os cälculos foram feitos segundo o método dos momentos, e os resultados obti dos para algumas amostras foram comparados com os obtidos através de outras fórmulas. Considera que os sinais obtidos para assime tria por diferentes fórmulas são compativeis, eque, portanto, os résultados de assimetria podem ser considerados reprodutiveis.

Uma anālise detalhada, por ambiente de deposição, levou DUA NE (1964) a admitir que a assimetria é sensivel ao ambiente: com sinal negativo indicaria remoção seletiva (winnowing) continua, caracteristica de praias, zonas litorâneas e canais de entrada de marés ( tidal inlets). Com sinal positivo caracterizaria zonas protegidas, de deposição, como lagunas, bem como dunas, de deposi ção eólica.

HAILS (1967) estudou mais de 1500 amostras na região costei ra New South wales (Austrâlia) de ilhas barreiras, praias, dunas e planicies flúvio-deltáicas, buscando um parâmetro que permitisse separar esses diversos ambientes. Mostrou que isso não poderia ser feito pelos diâmetros médios, nem pela morfologia (arredondamento) dos grãos e sim pela assimetria. Curiosamente, usou este critério para separar sedimentos holocênicos de pleistocênicos.

Entretanto, os dados de HAILS (1967) permitem também supor que as populações separadas refletem condições de ambientes prote gidos (inner barpier) ou de baixa energia (dunas), com assimetria positiva, ou abertos (front beach-outer barrier) com assimetria negativa. E certo que muitas amostras são de subsuperficie e po 
dem refletir condições pretéritas de exposição ou abrigo, porém, os resultados são indicativos de que o sinal da assimetria pode ser mais adequadamente referido a processos, e não a idades. Estas ültimas podem ser melhor deduzidas a partir da situação geológica e geomorfológica dos depósitos considerados.

Para FRIEDMAN (1967) as distribuições granulométricas têm significado genētico, permitindo distinguir com segurança seđimen tos fluviais de praiais. Para tanto sugere numerosas combinações gráficas de relação entre parâmetros ( por exemplo assimetria $x$ desvio-padrão) que permitiriam separar populações de diferentes origens.

CRONAN (1972) realizou estudo de sedimentos de superficie de fundo no Mar da Irlanda, entre a Ilha de Man e Cumberland, caracte rizados por polimodalidade. Para esse autor, a interpretação .. de DUANE (1964) de que assimetria negativa indicaria erosão ou não de posição, enquanto que assimetria positiva indicaria deposição, não pode ser estendida a sedimentos fortemente polimodais.

Assim, no caso do Mar da Irlanàa, hã uma deposição de sedi mentos cada vez mais finos de oeste para leste, à medida em que diminui a força das correntes de maré, de tal modo que os parâmetros estatísticos vão refletir as diferentes proporções de mistü ras de diferentes modas, e não o regime deposicional, que é unico. Cabe notar que essa conclusão é análoga à de FOLK \& WARD (1957) pá ra os sedimentos bimodais de Brazos Bar, e significaria que o diâmetro médio é antes indicativo de disponibilidade local de uma ou outra moda, que da distância com relação à área-fonte.

Essa controvérsia a respeito do significado dos parâmetros estatísticos permanece,e, a nosso ver, boa parte da literatura que consultamos acha-se permeada por discussões simultâneas envolvendo a precisão dos parâmetros estatisticos, e seu significado dinâmico. Um exemplo disto é o seguinte trecho de HAILS \& HOYT (1969, p.575): "o significado da assimetria como parâmetro sensível ao ambiente é demonstrado não somente pela distinção que pode ser feita entre am bientes de alta e baixa energia, como pela concoraancia no sinal da assimetria entre medidas gráficas e método dos momentos".

Trata-se de dois assuntos distintos. No que se refere aos pa râmetros descritores da distribuição granulomëtrica, SWAN et alii 
(1978) mostraxam que a correlação entre os mētodos gráficos e de momentos decresce do diâmetro médio, ao desvio-padrão, à . assime tria, à curtose. Em decorrência, pode-se discutir resultados dos dois primeiros parâmetros sem levar em conta o método de cālculo, diversamente dos dois restantes. Esta questão, bem como outras 1 i mitações decorrentes dos métodos utilizados, foram apresentados no CAPITULO 2, e serão retomadas oportunamente.

Ficando então no uso interpretativo dos parâmetros, apresen ta-se-nos, aparentemente, um paradoxo: se houver uma relação defi nida entre os parâmetros, ou seja, não sendo eìes independentes , qual o alcance de sua interpretação ? Tentaremos responder esta questão com base nos dados que vimos coletando nos últimos dez anos.

Assim, dos casos que anteriormente apresentamos, procedemos inicialmente à separação de conjuntos de dados a serem analisados. Visando eliminar, de início, possiveis alterações provenientes de diferenças de manipulação laboratorial, ređuzimos o universo de amostragem aos casos das baias de sepetiba, santos lamostras de 1980) e aos éstuārios de Itajaí-Açu (Campanha de 1982) e do Poten gi (somente amostras com menos que 50 \% de carbonatos), num total de 588 amostras, todas tratadas no mesmo laboratório.

As distribuições granulomētricas desses diversos conjuntos são descontinuas, abrangendo cada um deles, de modo preferencial, certos intervalos ou modas (FIGURA 120 ). Entretanto, todas essas amostras em conjunto caracterizam bastante bem o intervalo de $0 \varnothing$ a $8 \varnothing$, com pequenas caudas entre - $1 \varnothing$ e $0 \varnothing$ e $8 \varnothing$ e $9 \varnothing$ (FIGURA 121).

procuramos então iniciar nossa anālise atravēs da comparação do primeiro com os demais parâmetros, jā que o diâmetro médio se constitui numa medida cujo significado físico pode ser apreendido de modo relativamente simples. Construimos então os diagramas binā rios, apresentados nas FIGURAS 122 a 124. A fim de melhor captar as tendências esboçadas nos diagramas de pontos, realizamos um alisa mento (smoothing) que consistiu, basicamente, em se traçar uma cur va contínua através das medianas de cada 10 pontos.

A distribuição do desvio-padrão (FIGURA 122 ) mostra uma no tāvel ruptura em torno de $4 \varnothing$. Entre $0 \varnothing$ e $4 \varnothing$ as amostras distri buem-se em torno de um valor mëdio de assimetria de 0,74; pode - se 


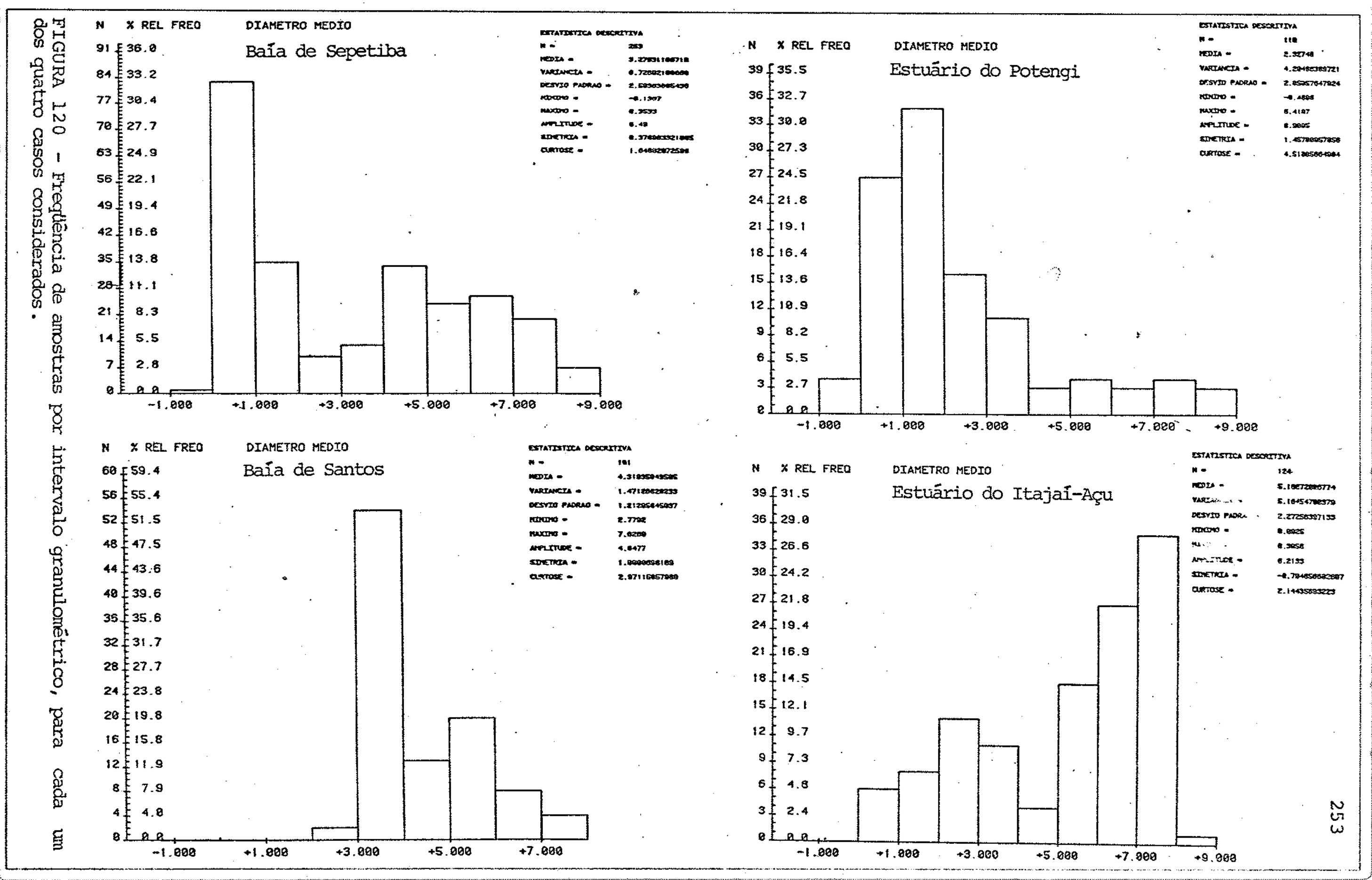




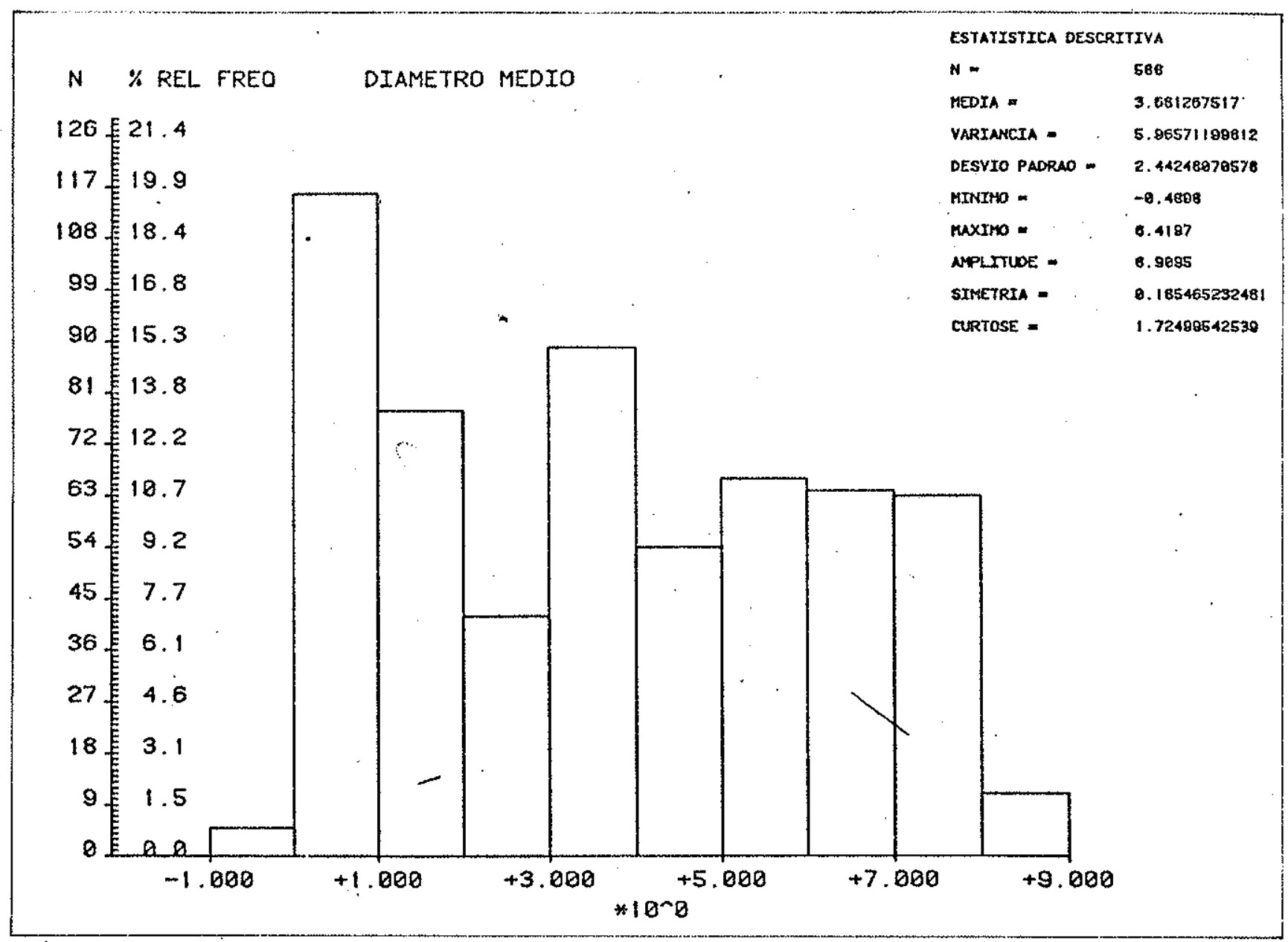

FICUPA 121- Frequência de amostras por intervalo graninométrico, para 588 amos tras das baías de sepetiba e Santos, e estuários de Itajai-Açu e potengi.

então dizer que todas as amostras desse intervalo granulométrico os cilam em torno de um grau de seleção que, pela escala de FOLK \& WARD (1957), corresponde a moderadamente selecionado. Ainda nesse intervalo de $0 \varnothing$ a $4 \varnothing$, pode-se notar que os desvios do desvio-padrão em torno dọ valor de 0,74 são menores de $0 \varnothing$ a $2 \varnothing$ que de $2 \varnothing$ a $4 \varnothing$, o que sugere duas populações distintas.

Entre $4 \varnothing$ e $8 \emptyset$ pode-se traçar uma média, provavelmente definida por uma equação de 29 grau, inteiramente compreendida nos in tervalos de valores pobremente a muito pobremente selecionados de FOLK \& WARD (1957). Neste caso nota-se que o desvio em torno da curva média diminui no intervalo granulomëtrico de $7 \varnothing$ a $8 \varnothing$.

Com relação à assimetria (FIGURA 123), embora o diagrama de pontos seja sugestivo de uma certa ruptura em torno de $4 \varnothing$, pare ce-nos que a tendência à definição de uma senóide pode ser estendi da entre $3 \phi$ e $8 \phi$, conforme fica mais claro no diagrama submetido a alisamento.

Novamente parece definir-se uma população entre $0 \not$ e $2 \emptyset$, cạ racterizada por valores oscilando em torno de assimetria nula. 
NE. DE PONTOS $=588$

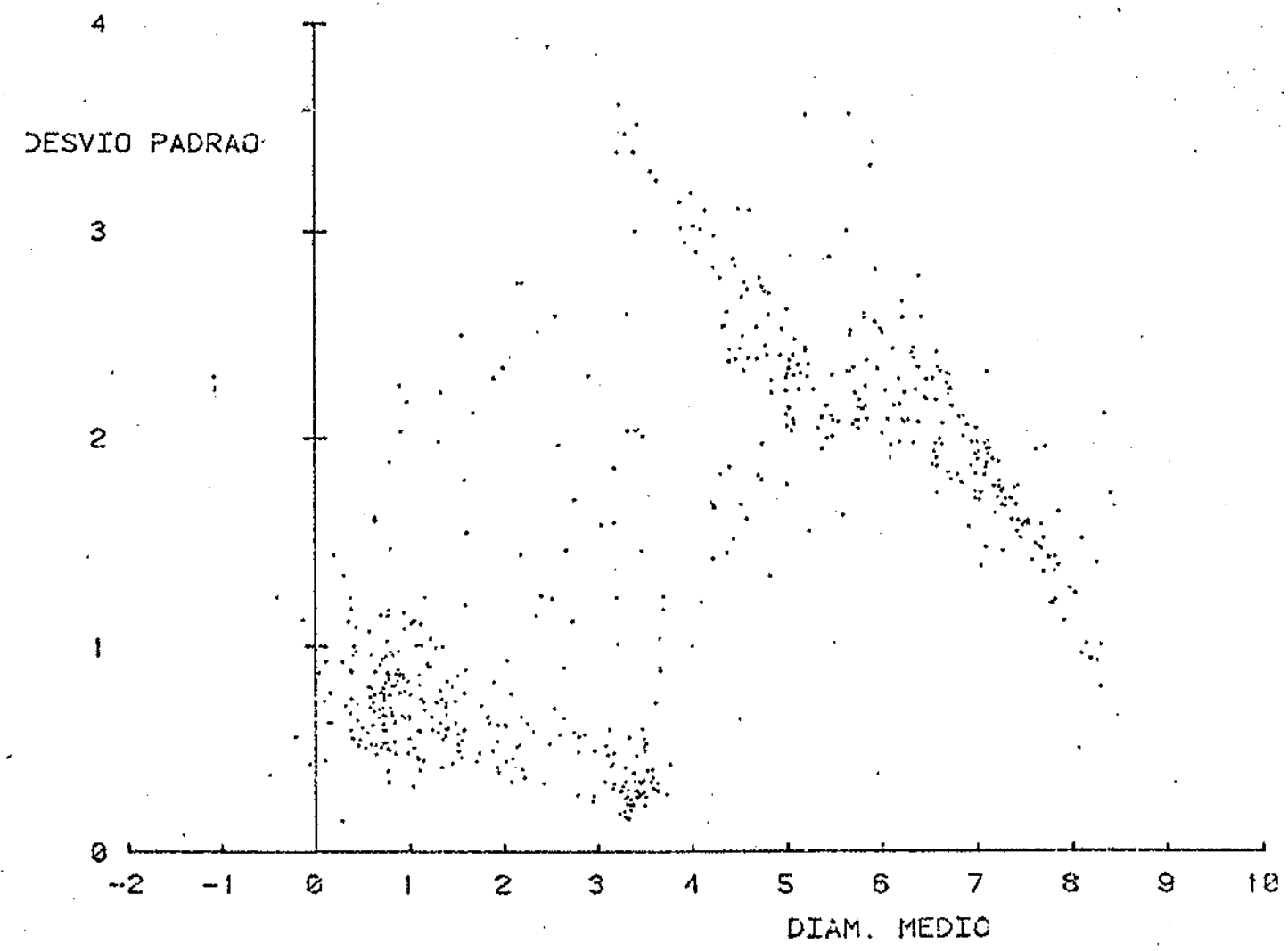

NO. DE FOITOS:588

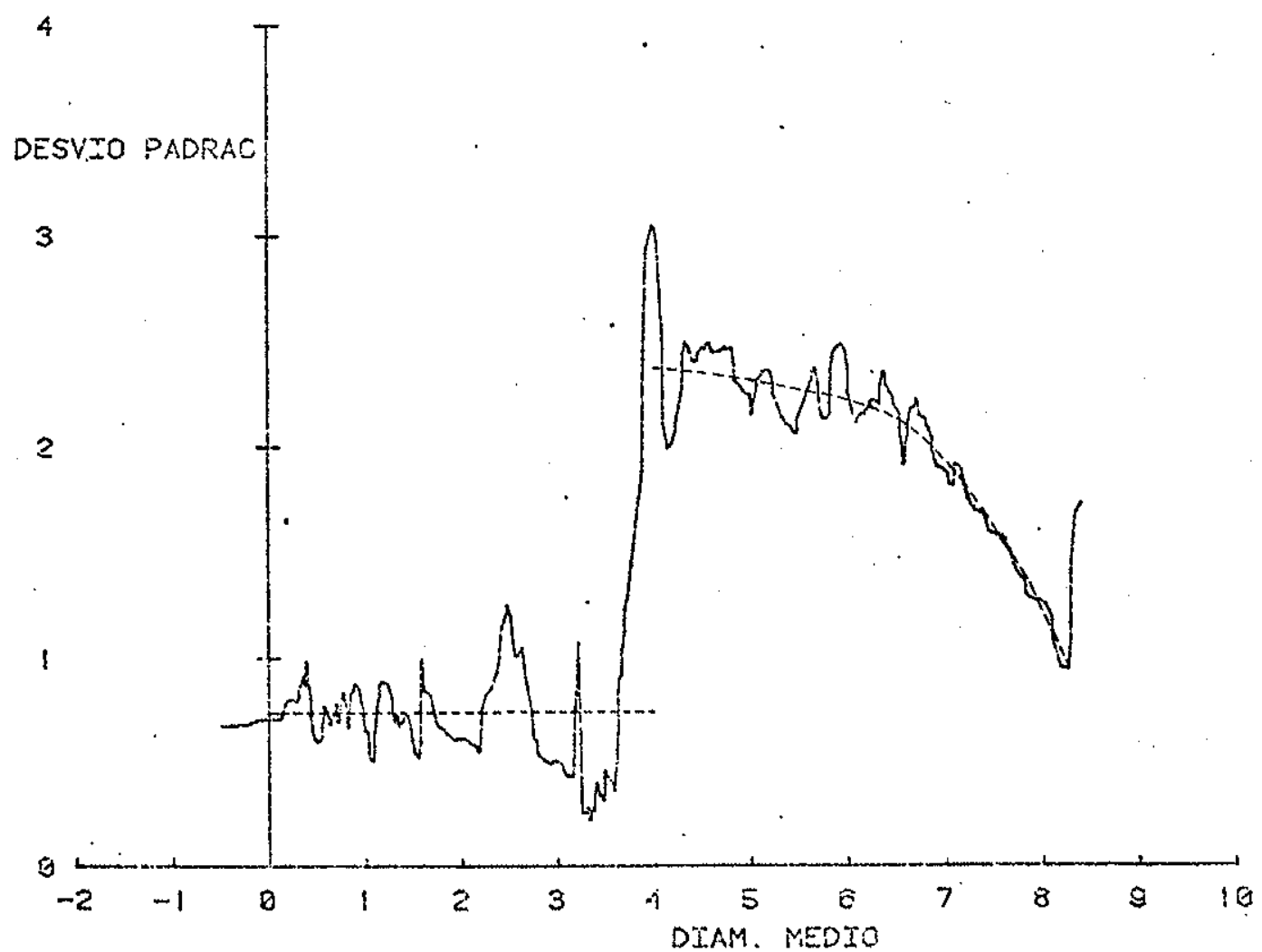

FIGURA 122 - Diagramas binários diâmetro médio $x$ desvio-padrão 
Ne. DE PONTOS $=588$

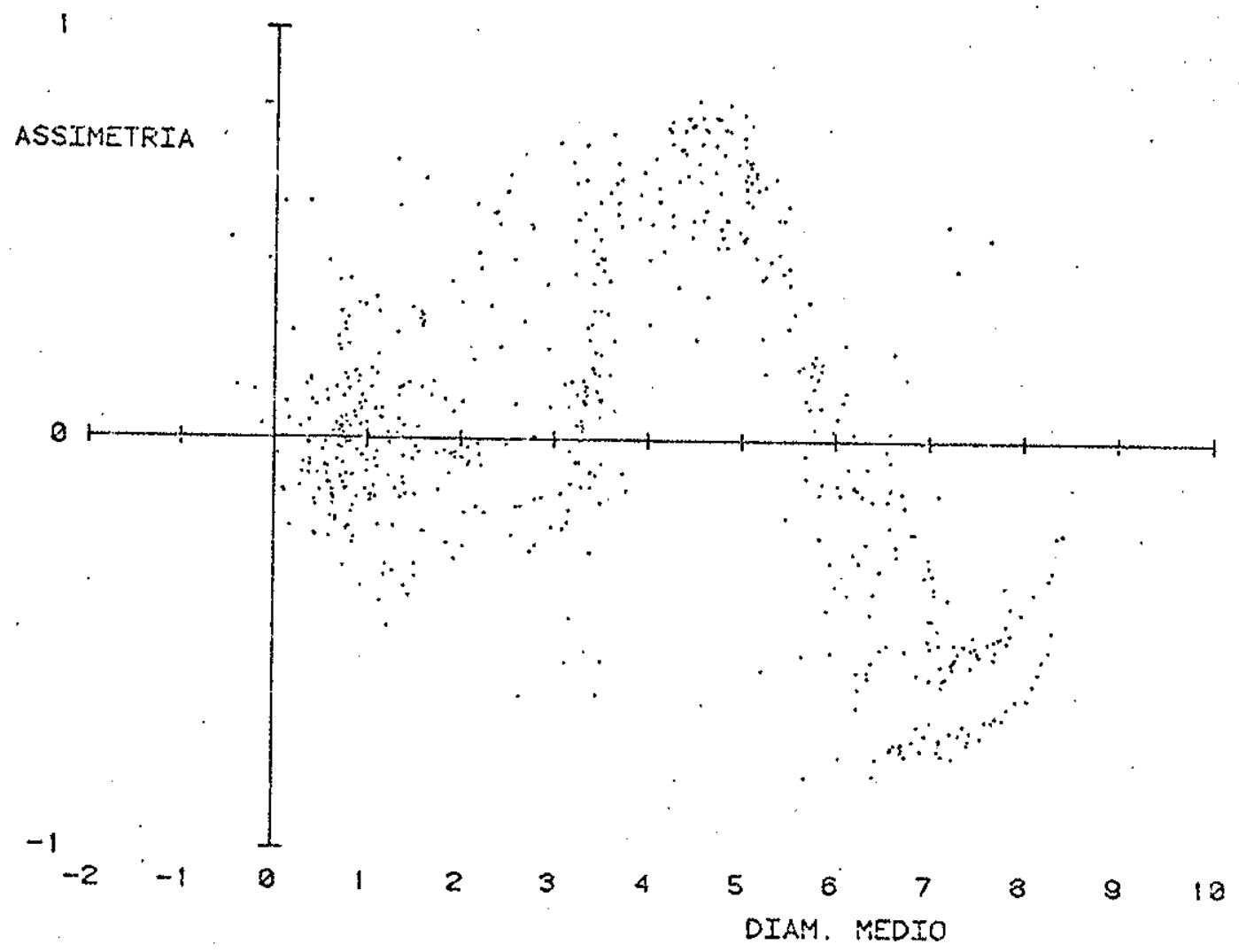

NO. DE PONTOS $=588$

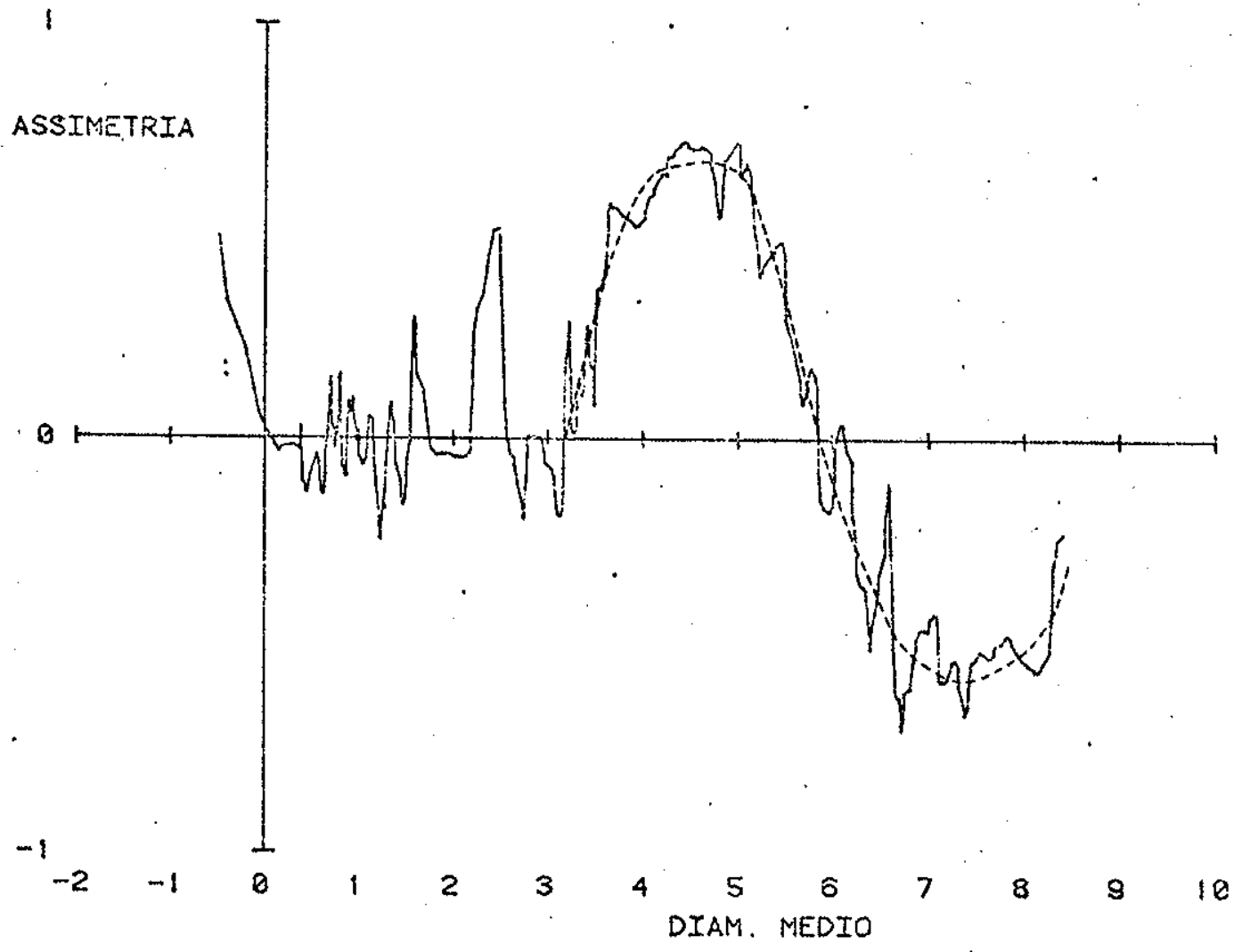

FIGURA 123 - Diagramas binārios diâmetro mëdio $x$ assimetria 
No que se refere à curtose (FIGURA 124), novamente jul.ga mos reconhec̈er très populações. Uma no intervalo granulométrico de $0 \varnothing$ a $2 \not$, com valores de curtose em torno de 1,2 (mesocúrtico), ou tra no intervalo $2 \varnothing$ a $4,5 \varnothing$ com valores de curtose em torno de 1,5 (leptocūrtico), e uma terceira, de $4,5 \varnothing$ a $8 \varnothing$, com valores platicurti cos a mesocürticos, segundo a escala de FOLK \& WARD (1957).

Com relação ao conjunto dos parâmetros, podemos então destacar que, para o universo analisado, é possîvel definir três con juntos de amostras, nos intervalos granulométricos aproximados de $0 \varnothing$ a $2 \varnothing$, de $2 \varnothing$ a $4 \varnothing$ e de $4 \varnothing$ a $8 \varnothing$. O primeiro desses intervalos ca racteriza-se por pequenas oscilações dos valores de desvio-padrão, assimetria e curtose, em torno de um valor médio (nulo, no caso da assimetria). o segundo guarda certa semelhança com o primeiro, caracterizando-se entretanto por maiores oscillações em torno do valor médio; o valor médio da curtose pará este caso é maior que no primeiro.

o intervalo de $4 \varnothing$ a $8 \varnothing$ caracteriza-se por uma relação mais complexa entre os parâmetros, embora bem definida nos diagramas binārios.

Os resultados acima expostos diferem substancialmente de ex pectativa de FOLK \& WARD (1957) (FIGURA 119), e nos levam a afir mar que as relações entre parâmetros grạulomētricos são válidas para dados intervalos granulométricos, não parecendo possível. de duzir uma única lei de comportamento cíclico, como a proposta por aqueles autores, aplicável a todos os intervalos granulométricos.

Adicionalmente, achamos oportuno retomar a questão assim proposta por FOLK \& WARD (1957, p.14): "Uma escala verbal de sele ção realmente significativa será desenvolvida somente quanto a tendência geral da relação entre tamanho (sic) e seleção for cons truída para um grande nümero de ambientes. Somente então será pos sível dizer, por exemplo, que um sedimento tem um desvio-padrão $0,25 \varnothing$ mais baixo que o sedimento médio correspondente àquele diâ metro mëdio".

Esse raciocínio parece-nos válido, e provavelmente seja um caminho a ser pesquisado e estabelecido para o futuro. Entretanto, julgamos que deva ser aplicado também aos demais parâmetros, ou seja, uma vez definida uma relação entre diâmetro médio, desvio- 
NO. DE PONTOS-583

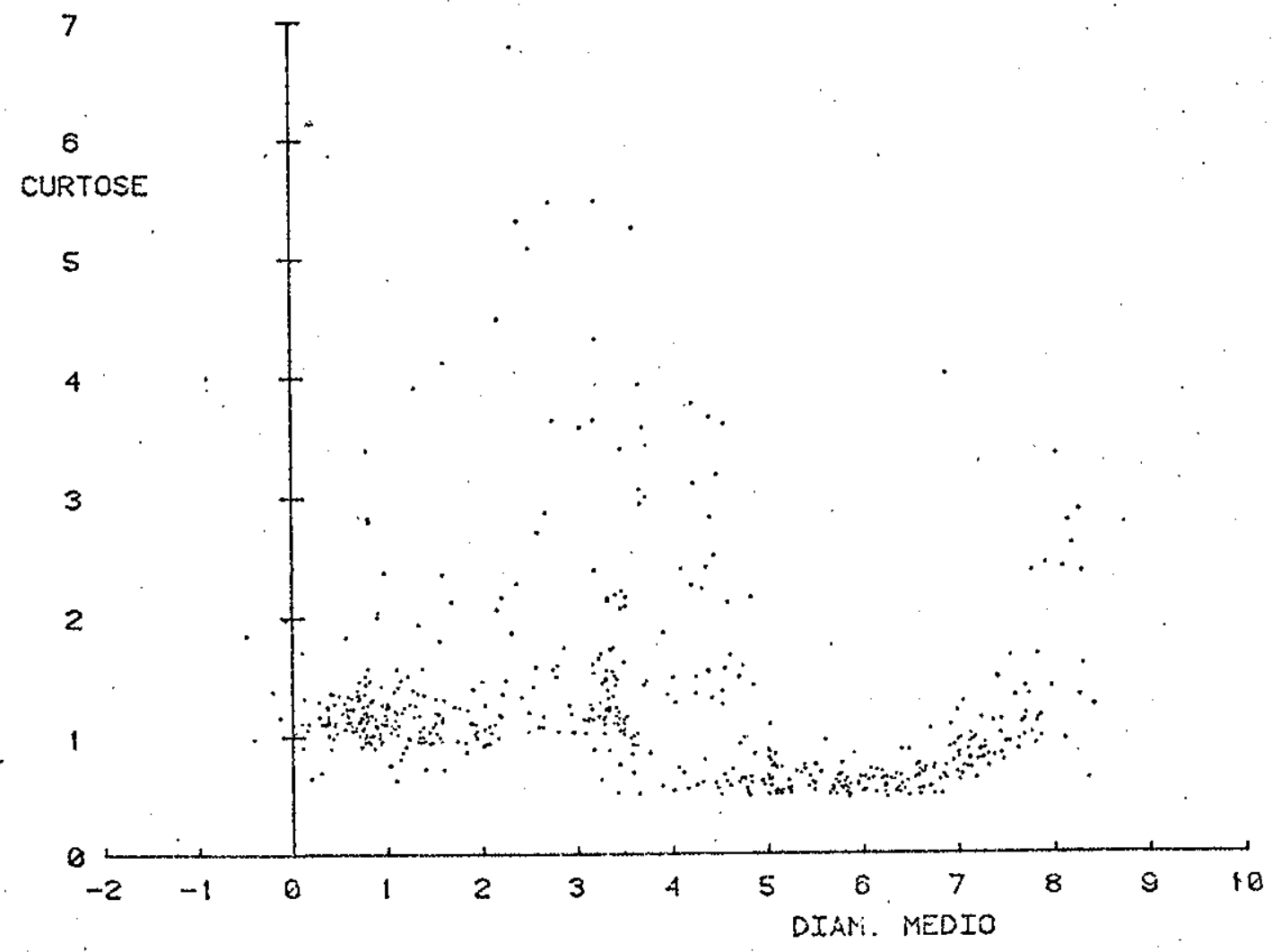

NO. OE PONTOS $=538$

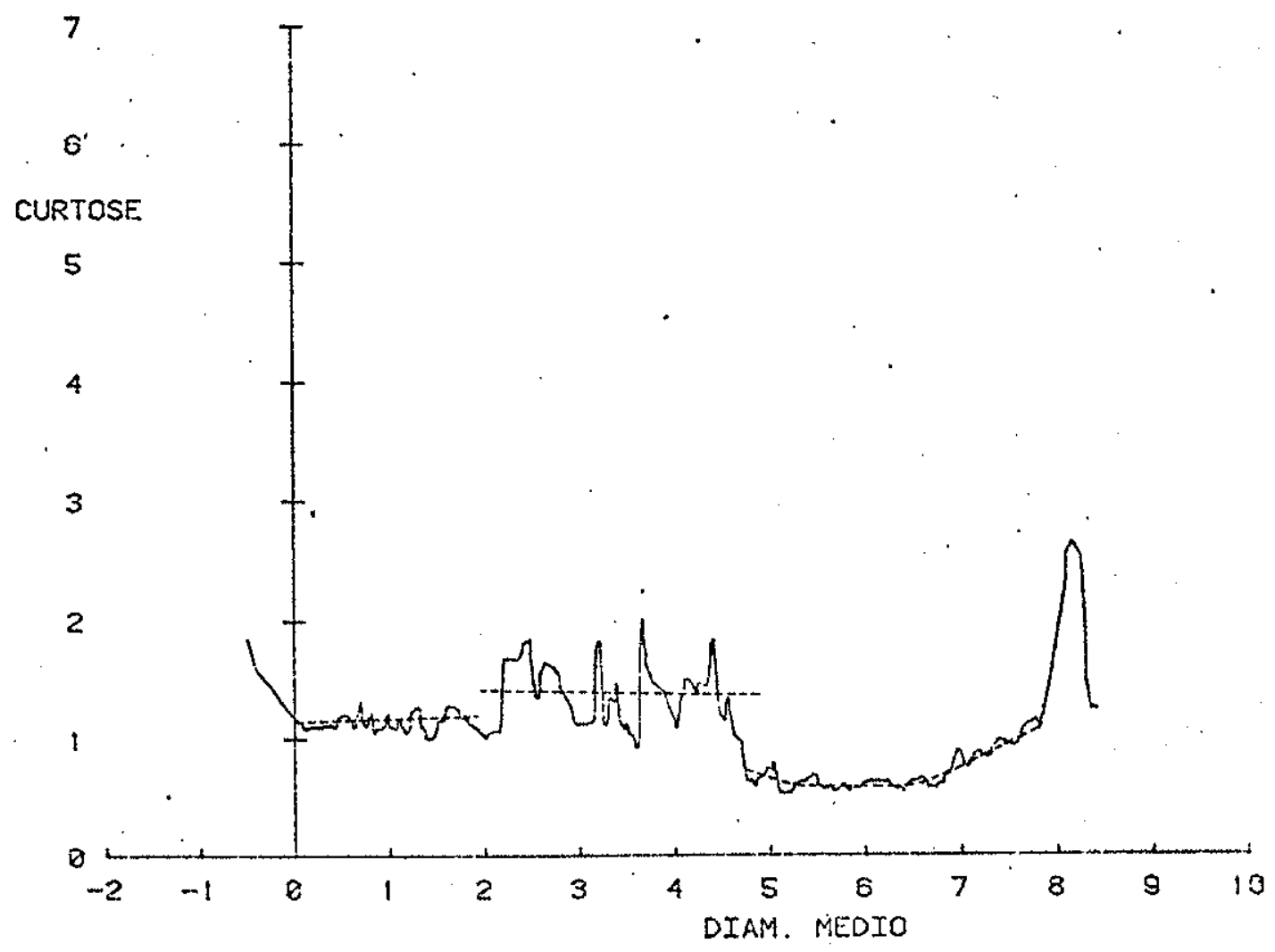

FIGURA 124 - Diagramas binärios diâmetro mëdio $x$ curtose 
-padrão, assimetria e curtose, não nos parece viāvel usar uma es cala absoluta para nenhum caso.

Naturalmente, esta discussão tem que ser tomada com algumas reservas, no sentido de não incorrermos em generalizações incorretas. Entretanto, parece-nos possivel constatar que, para as amostras analisadas, o único parâmetro com real significado físico é diâmetro médio, de tal sorte que cabe colocar düvidas quanto a interpretações dinâmicas oriundas dos demais.

Tendo assim proposto uma primeira abordagem para a solução do paradoxo anteriormente mencionado, podemo-nos perguntar a res peito do significado das três populaçöes acima definidas.

A descontinuidade mais notável, em torno de $4 \varnothing$, assinala não só a separação entre areias e siltes, como mudança de método gra nulométrico. Enquanto que para areias procede-se a peneiramento, estabelecendo-se portanto uma referência física para a separação das classes granulomētricas, siltes e argilas são divididos segun do a Lei de stokes, calculada para uma situação ideal. Ademais,os intervalos granulométricos são de $0,5 \emptyset$ no primeiro caso, e de $1 \varnothing$ no segundo, o que, de per se, causa aumento nos desvios-padrões por ampliação da base de cälculo. Entretanto, dada a abrupta passagem dos valores de desvio-padrão no limite de $4 \varnothing$, de 0,7 para 2,4 , hã margem para se suspeitar de que a passagem de areias pa ra siltes corresponda a uma mudança dinâmica, possivelmente o li mite entre transporte por arraste e suspensão, para as energias de transporte vigentes nos ambientes sedimentares aqui considerados.

Não temos elementos para avançar qualquer explicação fundą mentada em observação direta para o limite em torno de 2ø, limite entre areias médias e finas. Podemos apenas fazer uma suposição, de que, se de fato tal limite corresponde a um fenômeno natural, estarä possivelmente ligado à textura dos grãos, no sentido de seu arredondamento, por exemplo: neste caso, as partículas de $0 \varnothing$ a $2 \not$ poderiam ter uma tendência a formas mais homogêneas, de tal forma que a separação imposta pelo diâmetro dos orificios das peneiras levariam à separação de populações (de 0,5 em 0,5Ø) mais uniformes, portanto, com menores oscilações em torno de um va lor mẻdio de desvio-padrão.

Retomando agora as observações de SWAN et alii (1978) sobre 
os parâmetros de FOLK \&. WARD (1957) gostariamos de destacar que o significado dos diagramas binārios deverā decrescer no sentido diâmetro médio $x$ desvio-padrão, diâmetro médio $x$ assimetria, diâa metro médio $x$ curtose.

Levando em conta a complexidade das questões levantadas, não nos parece oportuno avançar esta discussão por meio da combinação de valores de desvio-padrão, assimetria e curtose entre si, con forme fizeram FOLK \& WARD (1957) e segundo a proposta de FRIEDMAN (1967).

\section{G GUARAS}

Alëm dos aspectos já contidos no CAPITULO 3 e anteriormente neste mesmo capitulo, parece-nos importante destacar aqui que o estudo do caso de Guarás, feito em base essencialmente mor fológica, poderia ser melhor esclarecido se este tipo de investi-gação houvesse sido estendido no sentido de caracterizar as ondas de areia. Levantamentos geofísicos poderiam fornecer informações quantitativas sobre essas feições, de modo a se obter um resultado independente dos demais (determinados principalmente através de cartas batimétricas e fotos aéreas), e a ser com eles comparado. Tais levantamentos deveriam ser defasados, de modo a não só carac terizar a geometria das ondas, como sua velocidade de mudança.

\section{AS BAIAS}

Uma caracteristica comum às três baías abordadas, santos, Sepetiba e Todos os Santos, è sua estreita vinculação com a circulação oceânica, através das correntes costeiras. Dominam estas inteiramente a circulação na baía santista, enquanto que nas ou tras duas os paleocanais wllmianos parecem ainda constituir um fa tor de expressão regional na distribuição das correntes de maré.

Mesmo levando em conta as restrições anteriormente apontadas quanto aos parâmetros granulométricos, os modelos de circulação propostos pa ra Santos e Sepetiba permanecem, considerando-se apenas a distribuição de fá

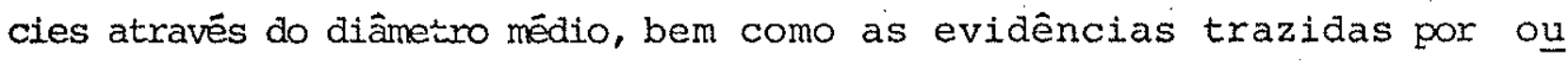
tros dados granulométricos brutos (porcentagens de argila, por exemplo), ou sobre a constituição dos sedimentos. 
Os pesquisadores da Bahia, em sua reconstituição paleoambiental da Baía de Todos os Santos, chamam a atenção para a possibi lidade de serem as areias reliquiares. Este ponto é da maior im portância na delimitação do uso que se pode fazer das fácies sedi mentares como indicadores do presente nivel de energia do meio de transporte, e coloca düvidas se os fundos arenosos de santos e Sepetiba correspondem à dinâmica sedimentar atual.

Pelo menos no caso de santos, medições de dispersão de ra dioisótopos mostram efetivo transporte de material arenoso, da ordem de $10 \frac{\mathrm{kg}}{\mathrm{m}} \times$ dia (verão) a $200 \frac{\mathrm{kg}}{\mathrm{m}} \times$ dia (inverno), na direção norte, com tendência a espalhamento para leste, (NUCLEBRẠs, 1981), ou seja, conforme sugerimos a partix da faciologia.

Parece-nos provável, então, dado o tipo de circulação das baías, que, embora parte das āreas aí encontradas sejam reliquiares, são elas efetivamente movimentadas por correntes atuais, cox respondendo então às regiões de maior energia de transporte.

No que se refere às variações temporais das fácies de super ficie de fundo, os padrões determinados em Santos, em succssivas campanhas ao longo de um ano, e em campanhas defasadas de sete anos, permaneceram relativamente constantes. Ainda este fato esta rá, provavelmente, vinculado à circulação marinha predominante; va riações sazonais relacionadas a mudanças de descargas fluviais se riam neste caso minimizadas, pois seus aportes sólidos seriam es palhados ao longo de toda a costa por correntes costeiras.

\section{OS ESTUARIOS}

Neste caso atenua-se a influência da circulação marinha e influenciam, embora com pesos diversos segundo o clima regional, as caracteristicas de vazão dos rios. Dos três casos estudados, o regime fluvial torna-se mais importante do Potengi a santos, e deste ao Itajaí-Açu.

No primeiro caso não temos dados suficientes para classificar o estuário; os existentes são sugestivos de que sua circulação seja dominada por correntes de maré, provavelmente com mistura ver tical de àguas.

o regime do estuário santista parece-nos adequadamente de terminado ao longo do Canal do porto e largos, necessitando com 
plementação no Canal de são vicente. O modelo de cunha salina an teriormente proposto para as duas ligações do estuārio coma baía foi modificado, sonforme vimos, face às novas investigações que aí realizamos.

E no caso de Itajaí-Açu que se realiza, de modo aproximado - modelo da cunha salina, embora faltem-nos ainda dados de veloci dades de corrente para completar esta caracterização. Este padrão de circulação está diretamente relacionado à predominância do flu xo fluvial, que em épocas excepcionais parece sobrepassar largamente as correntes de maxé. Assim, enquanto que os rios que desaguam na lagamar sabtista têm vazões relativamente baixas ( mēdia máxima mensal menor que $20 \mathrm{~m}^{3} / \mathrm{s}$ para o Cubatão) e estão dispersos em vārios locais do estuário, o Itajai-Açu tem médias mensais pre dominantemente acima de $100 \mathrm{~m}^{3} / \mathrm{s}$.

Variações temporais das fäcies de superfície de fundo foram investigadas somente no caso do Itajai-Açu, tendo-se constatado significativa mudança em suas caracteristicas, do regime de āguas - baixas ao de cheias. Dada a maior interveniēncia de correntes de marés nos casos de Santos e do Potengi, parece-nos razoável admitir, como hipótese de trabalho, que as fácies de superfície de fundo apresentem menor variação nésses dois casos.

Mais uma vez, levando em conta as restrições apontadas quan to aos parâmetros estatísticos granulométricos, podemos notar que não haverá mudanças significativas nas interpretações feitas, se usarmos tão somente parâmetros texturais e dados sobre a composição dos sedimentos. Assim, sugere-se enquantio essa questão não é definitivamente esclarecida, usar-se como critērios para delimitä ção de subambientes, a classificação textural de shepard, o diâme tro médio, dados granulométricos brutos e composição mineralōgica. Ademais, é preciso levar em conta também os limites indicados pe los estudos de salinidade e material em suspensão.

Um ponto brevemente aflorado e que aqui gostariamos de des tacar é o da inferência da circulação estuarina a partir das fá cies de superfície de fundo. Conforme verificamos no caso de san tos, um modelo de cunha salina foi inferido a partir da constatação de que sedimentos mais grossos adentravam o estuário, confor me fica especialmente claro na entrada do Canal de são Vicente. Is 
to significa tão somente que hä correntes de marés capazes de pro mover tal aporte; o pađrão de circulação das águas dependerả de ou tros fatores, como discutimos acima. Desse modo, este tipo de influência pode ser melhor realizado se, em não se dispondo de me dições de salinidades e velocidades de corrente, levarmos em conta elementos morfolögicos (seção do estuārio, padrão regional de dre nagem) e de descarga fluvial.

\section{. V ASSOREAMENTO}

No caso das baías, a questão do assoreamento, tal como pudemos estudā-la para sepetiba, pode ser equacionada sob a perspectiva de variações de energia do meio, detectadas através de elemen tos morfolōgicos de fundo e das fácies sedimentares. Uma aproxima ção quantitativa é possível de ser obtida através da anālise de variações batimétricas ou de linha de costa; entretanto caso as tendências assim apontadas se revelem crịticas, só medições dire tas podem precisar as quantidades efetivamente mobilizadas.

No caso dos estuários, alēm dos fatores regionais, tais como a situação geomorfológica, o padrão de circulação estuarino será determinante na determinação das frentes de turbidez máxima.

Esşe assunto apenas começa a ser estudado entre nós, e os resultados aqui apresentados necessitam ser ampliados especialmente na verificação do comportamento sazonal dessas frentes, o que permitiria, em futuro próximo, melhor planejar as épocas e locais preferenciais de campanhas de dragagem.

Finalmente, um aspecto a ser considerado, é que a eficiência das dragagens dependerá não só dos processos e locais responsãveis pelo assoreamento, como tambëm da adequada escolha do local de des pejo do material dragado. Para tanto, a determinação do padrão re gional de circulação deve ser conhecido, conforme demonstramos em Santos, e precauções quanto a feições ligadas ao equilibrio sedimentar tem que ser levados em conta, como é o caso da preservação dos mangues em Aratu. 


\section{CONCLUSÕES}

1. Os estudos geológicos aplicados a portos, no que diz res peito a profundidade e disposição dos canais de navegação e de atracação, podem ser vistos sob a perspectiva da constituição e permanência dos fundos subaquāticos. A caracterização desses fun dos pode ser feita de modo mais produtivo através da reconstitui ção de alguns eventos geológicos, essencialmente do Quaternāxio, de tal sorte a se integrar nessa história próxima os processos atuais. Dentre esses eventos tem especial importância o entalhe sincrônico ao ültimo evento glacioeustätico de rebaixamento do nível do mar (Würm), bem como as oscilações marinhas pōs-glaciais, baliza das pela Transgressão Flandriana ou Santos.

Os processos atuais podem ser definidos por critērios morfo lögicos e sedimentológicos, de modo, basicamente, a caracterizar a velocidade das mudanças das feições, bem como a constituição de seus materiais, conforme já propuséramos en nosso estudo sobre a Báa de Sepetiba (PONÇANO, 1976).

2. As mudanças morfológicas podem ser avaliadas por produ tos de sensores remotos, cartas batimêtrịcas, e reconhecimento de carnpo. Imagëns de sensores podem ser ūteis mesmo quando de uma úni ca data, pois permitem a deteç̧ão de paleoformas, que, datadas,per mitem estimar velocidades de acreção ou erosão. Entretanto, sensores e cartas batimétricas têm maior interesse quando provenientes de levantamentos defasados no tempo; seu uso é complementar: as cartas batimētricas, em suas sucessivas edições, sofrem alterações apenas nas profundidades, não passando por correções para mudanças de linha de costa. Estas podem ser definidas somente através de imagens de sensores

3. A caracterização sedimentológica pode ser feita, de modo complementar, para os sedimentos rasos da coluna sedimentar, para sedimentos de superficie de fundo, e para sedimentos em suspensão.

No primeiro caso tem-se mostrado útil a testemunhagem por cravação com amostrador do tipo piston corer; os resultados forne cidos permitem avaliar variações temporais da cobertura de superfí 
cie de fundo.

A faciologia dos sedimentos de superfície de fundo tem dupla utilidade: fornece indicadores da energia de transporte envolvida, e pode ser usada diretamente na preparação de modelos de simulação laboratoriais.

o estudo dos sedimentos em suspensão, associado ao de sali nidade e velocidade de correntes, permite definir padrões de circu lação, bem como definir regiões de turbidez mãxima, üteis na pre venção de assoreamento e plarejamento de aragagens em estuáxios.

4. No estudo sedimentológico do material de superficie de fundo, é aconselhāvel adotar-se tẻcnicas compatíveis com os resultados esperados. Assim, segundo SWAN et alii (1978), caso os "sedi mentos venham a ser descritos com parâmetros estatisticos calculados a partir do mëtodo dos nomentos, um intervalo de separação de $0,5 \not$ é desejāvel, enquanto que se utilizar as förmulas de FOLK \& WARD (1957), I $\varnothing$ é suficiente, qualquer que seja o intervalo granulomētrico considerado.

5. Empregamos as fórmulas de FOLK \& WARD (1957), cujos resul tados são compativeis com os obtidos pelo método dos momentos para diâmetro médio e desvio-padrão, diversamente do que ocorre com as simetria e curtose, conforme demonstraram SWAN et alii (1978). As sim, dé início, são os dois primeiros parâmetros mencionados , os mais confiāveis.

6. A literatura tem privilegiado a interpretação dinâmica dos parâmetros estatísticos de areias. Neste trabalho pudemos realizar uma apreciação desse assunto cobrindo, com 588 amostras reais, o intervalo de $0 \varnothing$ a $8 \varnothing$. Nele constatamos grande descontinuidade em $4 \varnothing$, limite de areias e siltes, especialmente nítido na distribui ção de diâmetros mëdios $x$ desvios-padrões; os valores de assimetria e curtose reforçam essa constatação. Embora fatores ligados às técnicas analíticas possam ser responsāveis por parte dessa des continuidade, parece-nos provável que ela se deva basicamente a diferenças na dinâmica de transporte entre areias e siltes.

7. Os quatro parâmetros estatísticos granulométricos dessas 588 amostras, apresentam relaçöes bastante definidas entre si, diversas entretanto das postuladas por FOLK \& WARD (1957). Os resul 
tados que obtivemos colocam sērias dúvidas quanto à possibilidade de se empregar os conceitos interpretativos correntes de grau de seleção, assimetria e curtose.

8. O diâmetro mëdio tem significado físico real, e deve ser usado como critério básico de interpretação, acrescido da classi ficação textural (SHEPARD, 1954) e do uso de dados referentes à composição da amostra, tais como porcentagens de argila, de grânu 10, e outros que puderem destacar alguma propriedade física do se - dimento.

9. A interpretação de processos atuais atravēs da faciologia deve sempre considerar a possibilidade de se estar tratando com depōsitos reliquiares. Verificação das interpretações sedimen tológicas atravēs de processos de medição direta de movimentação de sedimentos é desejāvel, antes de se fazer investimentos em obras ou de manutenção.

10. Os resultados obtidos em Guarás mostram que, alēm da ma nuttenção de profundidades de canais, a variação desses eixos de circulação deve ser avaliada. Os resultados obtidos nesta região, embora especificos, são emblemāticos de situações em que os volu mes de sedimentos movimentados naturalmente, ultrapassam marcas que inviabilizam, sob o ponto de vista econômico, qualquer possibilidade de construção, como é o caso de áreas próximas a delțas.

11. Nos casos das baías de Santos, sepetiba e Todos os Santos, pudemos destacar a necessidade de compreensão de padrões regionais de circulação, para melhor caracterização dos problemas locais.

12. Os estudos de estuários mostram padrões de circulação dependentes do clima e morfologia locais bem como do regime de marés. Assim, acentua-se a interferência fluvial da costa nordeste (Potengi) para a sudeste (Santos) para a sul (Itajai-Açu); tal influência é maior no caso de se ter um único canal (Itajaí-Açu ) que um complexo estuarino (Santos).

Realizamos, no presente trabalho, uma reavaliação de diversos fatores ligados à sedimentação do estuārio santista, entre eles a floculação e o modelo de circulação estuarina;mostramos que 
ao longo do Canal do porto e largos apresenta-se um padrão de cir culação em dois estratos, com mistura vertical, enquanto que o ca nal de são vicente apresenta circulação verticalmente homogênea.

Para o Itajaí-Açu, apresentamos estudo envolvendo; sob dife rentes condições de descarga fluvial, sedimentos de superficie de fundo e em suspensão. Este estuário apresenta circulação do tipo cunha salina em preamar, e em dois estratos com mistura vertical em baixa-mar.

13. Tanto no estuärio santista como no do Itajaī-Açu, a zo na da turbidez mäxima caracteriza-se por finos em suspensão prove nientes predominantemente da plataforma adjacente.

14. No que se refere às variações temporais das fácies de superficie de fundo, verificamos que são pouco importantes quando comandadas por circulação marinha - caso da Baía de Santos - e pronunciadas no estuärio do Itajaí-Açu. Neste ültimo caso, tem-se: um ünico canal estuarino, o que acentua a influência fluvial; po de-se esperar que no caso do estuario santista, que se desenvolve em intricado lagamar, com numerosos canais, a influência fluvial se dilua, com conseqtente maior permanência das fácies.

15. A caracterização de áreás de erosão e deposição, bem co mo de tendências evolutivas, deve basear-se, sempre que possivel. em critérios mültiplos, abrangendo três enfoques distintos: morfọ logia, sedimentos de superficie de fundo, e sedimentos em suspen são. Pudemos mostrar, no caso de Santos, que a dedução de um mode 10 de cunha salina, feita pelos autores prévios, a partir das fá cies de superfície de fundo, não é adequada; ainda neste caso pu demos mostrar, atravês da distribuição instantânea do material em suspensão, dependência da zona de turbidez máxima do aporte mari nho, diversamente tambēm das indicações prévias.

Uma vez estabelecido o padrão de circulação estuarina, en tretanto, inferências a partir das fäcies de superficie de fundo podem ser feitas com maior segurança. Assim, no caso do Itajaí-Açu, podemos constatar avanço das areias de origem marinha para o inte rior do estuārio, em torno de $500 \mathrm{~m}$ em regime de águas-baixas,com parativamente ao de águas altas. Ora, sabendo que neste caso o mo delo é de cunha salina, com proveniência de finos predominantemen 
te marinha, podemos fazer variar a frente de turbidez máxima se gundo as variações dos sedimentos de superficie de fundo.

16. Similarmente, a seleção de äreas de despejo, ou o plane jamento de campanhas de dragagem, devem apoiar-se nesses mesmos três fatores: feições especiais, como os mangues, devem ser pro tegidas. Variaçōes de fácies de superfície de fundo podem fornecer indicações sobre as āreas fontes do material sedimentar, como pudemos mostrar nos casos do Itajai-Açu e da Baía de Santos-Ponta - de Itaipu, enquanto que a delimitação das zonas de turbidez māxi ma devem contar, necessariamente, com estudo de materiais em suspensão. 
AB'SABER, A.N. 1.965. A evolução geomorfológica. In: AzEVEDO, A. A Baixada Santista: aspectos geogräficos. São Paulo, EDUSP.v.l. AB'SÁBER, A.N. 1969. Superfície aplainadas e terraços na Amazônia. São paulo, Instituto de Geografia/USP. (Geomorfologia, 4).

AB'SĀBER, A.N. 1969. Ritmo da epirogênese pós-cretäcica e setores das superfícies neogênicas em são paulo. São paulo, Instituto de Geografia/Usp. (Boletim, 13).

ALMEIDA, F.F.M. de. 1967. Origem e evolução da Plataforma Brasileira. Rio de Janeiro, DNPM/DFPM. (Boletim 241).

ALMETDA, F.F.M. de. 1976. The system of continental rifts bordering the Santos Basin, Brazil. An.Acad.Bras.Ciênc., Rio de Janeiro, 48 (supl.) : 15-26.

ANDRADE, G.O. de. 1970. Os climas: In: AZEVEDO, A. Brasil; a terra e o homem. São Paulo, EDUSP. Ed. Nacional. v.l.

ARANTES, J.I.G.; DAMASCENO, B.C.; KREBS, A.S.J. 1972. Projeto ar gila, Belëm. Belëm, CPRM.

AZEVEDO, A. 1960. Fisionomia da cidade de Salvador em Cidade do Salvador. sL., Imprensa Oficial da Bahia.

AVANZO', P. 1980. Corrijam-se os mapas: o Paraguaçu desagua a vinte quilômetros acima. s.n.t. (inédito).

AZEVEDO, A. coord. 1965. A baixada santista: aspectos geográficos. São Paulo, EDUSP. $4 \mathrm{v}$.

BACOCCOLI, G. 1971. Os deltas marinhos holocênicos brasileiros : uma tentativa de classificação. Bol.Tec.Petrobrās, Rio de Ja neiro, $14(1 / 2): 5-38$.

BISTRICHI, C.A. et alii. 1981. Mapa geológico do estado de São Pau 10; escala 1:1 000 000. São paulo, IPT. v.2. (Monografias,6).

BITTENCOURT, A.C. da S.P.; BRICHTA, A.; NAPOLI, E. 1974. A sedimentação na Baía de Aratu, Bahịa. Rev.Bras.Geoc., 4 (1):51-64, mar.

BITTENCOURT, A.C. da S.P.; EERREIRA, Y.A.; NAPOLI, E. 1976.Alguns 
aspectos da sedimentação na Baj̃a de Todos os Santos, Bahía. Rev. Bras. Geoc., 6 (4).

BITTENCOURT, A.C. da S.P. et alii. 1979. Quaternary marine forma tions of the coast of the state of Bahia, Brazil. In: INTERNA TIONAL SYMPOSIUM On COASTAL EVOLUTION in the QUATERNARY, São Paulo, 1978. proceedings... São Paulo, IGCP/IGUSP/SBG. p.232253.

BLANC, J.J. 1982. Sédimentation des marges continentales: actuelles et anciennes. Miasson.

BOKUNIEWICZ, H.J.; GORDON, R.B.; KASTENS, K.A. 1977. Form and migration of sand waves in a large estuary, Long Island sound. Marine Geology, 24:185-199.

BOUROCHOV, J.M. \& SAPORTA, G. 1982. Análise de dados. Rio de Ją neiro, Zahar Ed.

BOWDEN, K.F. 1967. Circulation and diffusion.In: LAUFF, G.H. ed. Estuaries. Washington, American Association for the Advancement of Science. p. 15-36. (Publication, 83).

BRUUN, P. 1976. Port engineering. Houston, Gulf Publ.

CAMARGo, F. P. de 1976. Geologia de engenharia. Construção Pesada, 6 (61):101-102, fev.

CAMPOS, J.S. 1940. Fortificacões da Bahia. s.L.., Serviço do Patri mónio Histórico e Artístico Nacional. (Publicação, 7).

CARVAJHO, A.D.S. 1960. O crescimento recente da cidade de Salva dor em Cidade do Salvador. s.L., Imprensa Oficial da Bahia.

CAUNIN, R.1972. Cartographie générale. Paris, Eyrolles. Tome 1 . (Collection Scientifique de l'Institut Gëographique National :).

CHAVES, H.A.F. 1983. Introdução geral. In: PETROLEO BRASILEIRO.Re conhecimento global da margem continental brasileira: processos e métodos; relatório final. Rio de Janeiro, PETROBRAS/CENPES/ STNTEP. p.7-23. (PROJETO REMAC, 6).

CosTA, I.M: 1960. Eortificações coloniais em Cidade do Salvador. s.L., Imprensa Oficial da Bahia.

CRONAN, C.S. 1972. Skewness and Kurtosis in polymodel sediments 
from the Irish Sea. Jour. Sedim. Petrol., 42 (1).

CURRAY, J.R. 1969. Estuaries, lagoons, tidal flats and deltas.In: AMERICAN GEOLOGICAI INSTITUTE. The new concepts of continental margin sedimentation: application to geological record. Was hington. p. JCIII-1-JCIII- 30 .

DEPARTAMENTO de ÁGUAS e ENERGIA ELETRICA. Centro Tecnológico de Hidráulica. Divisão de Hidrogeologia. 1974. Dados fluviomêtri cos coligidos até 1970 na quinta zona hidrográfica, Bacia do Rio Ribeira de Iguape e Bacias Litorâneas. Boletim Fluviométrico, São paulo, (2):1-391.

DUANE, D.B. 1964. Significance of skewness in recent sediments, Western Pimlico Sound, North Carolina. Jour. Sedim. Petrol, 34 (4).

EMERY, K.O. 1967. Estuaries and lagoons in relation to continental shelves. In: LAUFF, G.H. ea. Estuaries. Washington, American Association for the Advancement of Science. p.9-11. (Publication 83).

ESCOLA POLITECNICA da UNIVERSIDADE de SÃO PAULO. Divisão de $\therefore$ Hi arāulica Maritima. 1966. O estuário santista: pesquisas sobre - assoreamento verificado na faixa portuäria, para a Companhia Doças de Santos. São Paulo, DAEE. cap.3, f1.14-101.

FAIRBRIDGE, R.W. 1966. Mean sea-level changes, long term eustatic and other. In: THE ENCYCLOPEDIA of oceanography. New York. v. 1 , p. $479-485$.

FLINT, R.F. 1971. Glacial and quaternary geology. New York, John Wiley.

Foly, R.L. 1962. Of skewness and sands. Jour.Sedim.Petro1.,32:145 -156 .

FOLK, R.L. \& WARD, W.C. 1957.Brazos river bar: a study in significance of grain size parameters. Jour. Sedim.Petrol., 27:2-26.

FRANCISCO, B.H.R. et alii. 1971. Contribuição à geologia da Folha de são Luiz (SA-23). Belēm, INPA. 40 p.il. (Boletim do Museu Paraense Emilio Goeldi, Nova Sẻrie, Geologia, 17). 
FRETTAS, R.O. de 1.951. Ensaio sobre a tectônica moderna do Brasil. são Paulo, FFCLUSP. (Boletim 130, Geologia 6) :

FRIEDMAN, G.M. 1967. Dynamic processes and statistical parameters compared for size frequency distribution of beach and river sands. Jour. Sedim.Petrol., $37(2)$.

FULFARO, V.J. \& PONÇANO, W.L. 1976. Sedimentação atual do estuã rio e baía de santos: um modelo geológico aplicado a projetos de expansão da zona portuäria. In: CONGRESSO BRASIIEIRO de GEOLOGIA de ENGENHARIA, 1, Rio de Janeiro, 1976. Anais... Rio de Janeiro, ABGE. v.2, p.67-90.

FOLFARO, V.J.; PONÇANO, W.L.; GIMENEZ, A.F. 1976. Sobre o signifi cado dos depósitos argilosos do estuário santista: contribuição ao estabelecimento de um modelo de sedimentação da ārea de interesse ao porto. In: CONGRESSO BRASILEIRO de GEOLOGIA de ENGENHARIA, 1, Rio de Janeiro; 1976. Anais... Rio de Janeiro, ABGE. v.2, p.141-150.

FULFARO, V.J.; PONÇANO, W.I.; GIMENEZ, A.F.1978. Sedirentação atual na foz do rio potengi, Rio Grande do Norte: subsidio ao plane jamento da ampliação do porto. In: CONGRESSO BRASILEIRO de GEOLOGIA de ENGENHARIA, 2, São paulo, 1978. Anais... São pau 10: ABGE. v.2, p. 85-110.

GEORGE, P.1967- Geografia econômica. Rio de Janeiro, Fundo de CuI tura, Biblioteca do Fundo Universal, Estante de Economia. p. 318 .

GHOSH, J.K.; MAZUMDER, B.S.; SENGUPTA, S. 1981. Methods for compu tation of suspended load from bed materials. Sedimentology, 28 : $781-791$.

GORDILHO, W. 1960. Contribuição ao estudo da evolução urbana da cidade de Salvador em Cidade do Salvador. s.L., Imprensa ofi cial da Bahia.

HAILS, J.R. 1967. Significance of statistical parameters for dis tinguishing sedimentary environments in New South Wales, Australia. Jour. Sedim. Petrol., 37 (4).

HAILS, J.R. \& HOYT, J.H. 1969. The signiticance and limitation of 
statistical parameters for distinguishing ancient and modern sedimentary environments of the Lower Georgia Coastal Plain. Jour.sedim.Petrol. 39 (2).

HERZ, R. 1979. Spatial and temporal variations in lagoon and coastal processes of the Southern Brazilian Coast. In: INTER NATIONAL SYMPOSIUM On REMOTE SENSING Of ENVIRONMENT, 13, Ann Arbor, 1979. Proceedings... poster session E.

HILLIER, G.J. 1984. Analysing turbidity in estuaries: a literatu re review. Pais de Gales University of Bangor. 49p. (inëdito).

INMAN, D.L. 1952. Measures for describing the size distribution of sediments. Jour.Sedim.Petrol. 22: 125-145.

JOHN, K.W. 1974. O 20 Congresso Internacional de Geologia de En genharia; são Paulo, Brasil, 18. a 24 de agosto de 1974, revi são e análise. Informativo ABGE, São Paulo, (1).

KEMPE, M.; MABESOONE, J.M.; COUTINHO, P.N. 1972. Characterization of surface sediments on the northern. and eastern Brazilian shelf. In: COINGKESSO BRASILETRO de GEOLOGIA, 26, Be1Ë, 1972. Anais...Belém, SBG. v.2, p.261-265

KOWSMANN, R.O. \& COSTA, M.P.A. 1979. Evidence of late quaternary sea level stillstands on the Upper Brazilian Continental: a synthesis In: INTERNATIONAL SYMPOSIUM On COASTAL EVOLUTION in the QUATERNARY, São Paulo, 1978. proceedings... são paulo, IGCP/IGUSP/SBG. p.170-192.

KRANK, K. 1975. Sediments deposition from flocculated suspension. Sedimentology, 22: 111-123.

KRANK, K. 1981. Particulate grain-size characteristics and flocculation in a paxtially mixed estuary. Sedimentology, 28: $107-114$.

KRUMBEIN, W.C. \& SLOSS, L.L.1963. Stratigraphy and sedimentation. San Francisco, W. H. Freeman.

KUTNER, A.S.1962. Granulometria dos sedimentos de fundo da re gião de Cananéia, SP. Bol.Soc.Bras.Geol., São Paulo,11. (2) : $41-54$, nov. 
KUPNER, A.S. 1963. Estudo sedimentolögico e mineralögico da ensea da do Mar Virado, Ubatuba, sp. São Paulo, Instituto Oceanogrä fico/USP. (Oceanografia Física, 5).

KUTNER, A.S. 1969. A sedimentação no Canal de São Sebastião. São Paulo. (Estudo realizado para a firma BRASCONsuLT, destinado ao Projeto Básico do porto de são sebastião) .

KUTNER, A.S. 1976. Levantamentos sedimentológicos de apoio na pes quisa e reconhecimento de āreas portuārias. In: CONGRESSO BRA SILEIRO de GEOLOGIA de ENGENHARIA, 1, Rio de Janeiro, 1976 . Anai.s... Rio de Janeiro, ABGE. v.2, p.47-66.

LANGHORNE, D.N. 1973. A sandwave field in the outer Thames estua-ry, Great Britain. Marine Geology, 32: M19-M27.

LEÃO, Z.M. de A.N. \& BITTENCOURT, A.C. da S.P. 1977. A fração bìo detritica dos sedimentos de fundo da Baia de Aratu, BA. Rev. Bras.Geoc., 7 (2): 115-130, jun.

MABESOONE, J.M.; CAMPOS e SILVA, A.; BEURLEN, K. 1972. Estratigra fia e origem do Grupo Barreiras em Pernambuco, Raraiba e Ric Grande do Norte. Rev.Bras.Geoc., 2 (3):173-188, set.

MAGLIOCCA, A. \& KUTNER, A.S. 1964: Conteúdo orgânico dos sedimentos de fundo de Cananēia. São Paulo, Instituto oceanográfico/ USP. (Oceanografia Física, 7).

MAGLIOCCA, A. \& KUTNER, A.S. 1965. Sedimentos de fundo da enseada do Flamengo, Ubatuba. São Faulo, Instituto Oceanográfico/USP. (Oceanografia Física, 8).

MARTIN, L. et alii.1979a. Le quaternaire marin du littoral brësi lien entre Cananéia, SP et Barxa de Guaratiba, RJ. In: INTER NATIONAL SYMPOSIUM On COASTAL, EVOLUTION in the QUATERNARY, São Paulo, 1978. Proceedings.... São Paulo, IGCP/IGUSP. p. 296-331.

MARTIN, L. et alii. 1979b. Courbe de variation du niveau relatif de la mer au cours des 7000 dernières années sur un secteur homogène du littoral brésilien, nord de Salvador - Bahia. In: INTERNATIONAIS SYMPOSIUM On COASTAL EVOLUTION in the QUATERNARY, São Paulo, 1978. Proceedings... São Paulo, IGCP/IGUSP/SBG. p. $264-274$. 
MAR'IONNE, E. de 1935. Cartographie coloniale. Paris

MELO, M.S. de \& PONÇANO, W.L. 1983. Gênese, distribuição e estratigrafia dos depósitos cenozöicos no Estado de são Paulo. São Paulo, IPT. (Monografias, 9).

MESQUITA, M. 1977. Transporte. In: INSTITUTO BRASILEIRO de GEOGRA FIA e ESTATISTICA. Geografia do Brasil, região nordeste. Rio de Janeiro, SERGRAF. v. 2.

MILLIMAN, J.D. et alii. 1972. Superficial sedimentes of the Brazj. lian Continental Margin. In: CONGRESSO BRASILEIRO de GEOLOGIA, 26, Belëm, 1972. Anais... Belëm, SBG. v.2, p.29-44.

OLIVETRA, A.M. dos S.1981. Estudo da percolação d'água em macicos rochosos para o projeto de grandes barragens. São Paulo ( Dis sertação de Mestrado, IGUSP.).

PENTEADO, A.R.1970. O homem brasileiro e ó meio. In: AzEVEDO, A. ed. Brasil; a terra e o homem. São Paulo, EDUSP. Ed.Nacional. $\mathrm{v} .2$.

PETROLEO BRASILEIRO \& INSTITUTO de GEOCIENCIAS da UNIVERSIDADE de SÃo PAULO. Projeto Rio Doce; relatório final. São Paulo.

PETRONE, P.1965. Povoamento e população. In: AZEVEDO, A. A Baixam da Santista: aspectos geográficos. São Pallo, EDUSP. v.2.

PICHLER E: 1954. Diretrizes para o estudo geológico de barragens. São Paulo, IPT. (Publicação IPT, 507).

PICHLER, E. 1957. Aspectos geológicos dos escorregamentos de san tos. Bol.Soc.Bras.Geol., são Paulo, 6 (2):61-68.

PIMENTA, J. 1959. Deltas intermittents; existence a'un paléodelta de l'Amazone. Eclogae Geol. Helvetiae, 51:551-561.

PONÇANO, W.L. 1976a. Sedimentação atual na baía de sepetiba, Esta do do Rio de Janeiro: contribuição à avaliação de viabilidade geotécnica da implantação de um porto. São Paulo.2v. (Disserta ção de Mestrado/IGUSP).

PONÇANO, W.I. 1976b. Características gerais da sedimentação e cor rentes costeiras entre Santos e Cananéia. Noticia Geomorfológica, Campinas, 16 (31): 107-111, jun. 
PONÇANO, W.L. \& FULFARO, V.J. 1976. Sedjmentação atual nas adjacên cias da ponta de Itaipu e Baia de Santos: impljcações na esco Tha de locais de lançamento de matexial dragado. Tn: Congresso BRASILEIRO de GFOLOGIA de ENGENHARTA, 1, Rio de Janeiro, 1976. Anais... Rio de Janeiro, ABGE. v.2, p.91-110.

PONÇANO, W.I. \& FULFARO, V.J. 1978. Dynamic significance of grain size parameters in coastal areas. In: INTERNATIONAL CONGRESS of the INTERNATIONAL ASSOCLATION Of ENGINEERING GEOLOGY, 3,Madrid, 1978. Proceedings... Madrid, IAFG. v.1, sec.2, p.268-277.

PONÇANO, W.L.; FULFARO, V.J.; GIMENEZ, A.E' . 1976. Sedimentação atual na bacia de Sepetiba, Estado do Rio de Janeiro: contribuição a avaliação de viabilidade geotécnica da implantação de um porto. In: CONGRESSO BRASILETRO de GEOLOGIA de ENGENHARIA, 1, Rio de Janeiro, 1976. Anais... Rio de Janeiro, ABGE. v.2, p.111-140.

PONÇANO, W.L.; FULFARO, V.; GLMENEZ, A.F. 1979. Sobre a origem da baia de sepetiba e da restinga de Marambaia, RJ. In: SIMPOSIO REGIONAL de GEOLOGIA, 2, Rio Claro, 1979. Atas... são Paulo, SBG. V.I, p.29I-304.

PORTOBRAs, . 1979. Plano Diretor Portuärio do Brasil. s.L.

POSTMA, H. 1967. Sediment transport and sedimentation in the estua rine environment. In: LAUFF, G.H. ed. Estuaries. Washington, American Association for the Advancenent of Science, p.1.58-179. (Publication, 83).

QUINN, A. 1972. Design and constrution of ports and marine structures New York, McGrawhill.

RUSSEL, R.J. 1967. Origins of estuaries. In: LAUFF, G.H. ed: Estua ries. Washington, American Association for the Advancement of Science. p.93-99 (Publication, 83).

SANTOS, M. 1959. O centro da cidade de Salvador. s.L. (Tese apre sentada à Universidade de Strasbourg) (Publicação da universida de Federal da Bahia, 4).

SENGUPTA, S. 1975. Sizemsorting during suspension transportation, lognormality and other characteristics. Sedimentology,22:257273. 
SENGUPTA, S. 1979. Grain-size distribution of suspended load in relation to bed materials and flow velocity. Sedimentology, 26 : $63-82$.

SILVESTER, R. 1968. Sediment transport, long-term net movement . In: FAIRBRIDGE, R.W. ed. Encyclopedia of Geomorphology.London, Reinhold. p.985-988.

SILVESTER, R. 1974. Coastal engineering. Amsterdam, Elsevier. 2v. (Developments in Geotechnical Engineering, 4B).

SUGUIO, K. 1973. Introdução à sedimentologia. São Paulo, Edgara. Blücher.

SUGUIO, K. \& MARTIN, L. 1978a. Mapas geológicos 1:100 000 cobrindo a costa paulista. São Paulo, DAEE.

SUGUIO, K. \& MARTIN, L. 1978b. Formações quaternārias marinhas do litoral paulista e sul fluminense. In: INTERNATIONAL SYMPOSIUM on COASTAL EVOLUTION QUATERNARY, São Paulo, 1978. Special Pu blication, São Paulo, IGCP/IGUSP/SBG, (1) .

SWAN, D.D.; CLAOUE, J.J.; LUTERNAUER, J.L. 1978. Grain-size otatis tics I: evaluation of the Folk and ward graphic measures.Jour. Sedim. Petrol.; 48 (3): 863-878, sept.

SWAN , D.D.; CLAQUE, J.J.; LUTERNAUER, J.L. 1979. Grain-size sta tistics. II: evaluation of grouped moment measures. Jour.Sedim. petrol., 49 (2):487-500, jun.

SWIFT, D.J.P.; SCHUBEL, J.R.; SHELDON, R. W. 1972. Size analysis of fine-grained suspended sediments: a review. Jour. of sedim. Petrol., $42 \cdot(1): 122-134$.

TRICART, J. 1972. The landforms of the humid tropics: forests and savannas. London, Longman.

VARGAS, B.M. 1983. Evolução histörico-morfolögica do estuärio do Rio Itajaí-Açu e sua implicação no porto de Itajaí-Açu, Rio de Janeiro, Portobrās/INPH. (Relatório 900/01-139/83).

VILAS BOAS, G.S. \& BITTENCOURT, A.C.S.P. 1979. Mineralogia e com posição química da fração argilosa dos sedimentos de fundo da Baía de Todos os Santos, Bahia. Rev.Eras.Geoc. 19 (3):179-197, set. 
VILAS BOAS, G.S. \& NASCIMENTO, M.A.M.1979. Evoluçăo paleogegräfica e paleoclimatica dạ região das enseadas dos Tainheiros e do Cabrito, BA, nos ültimos 5000 anos. Rev.Bras.Geoc. 9 (3) : 159-168, set.

VILLAGRA, H.M.I. et alii. 1980. Metodologia de utilização de imą gens orbitais em oceanografia. In: INSTITUTO de PESQUISAS ES PACIAIS. Curso de treinamento: aplicações de sensoriamento re moto, com ênfase em imagens LANDSAT, no levantamento de recur sos naturais. São José dos Campos. (Relatōrio INPE-1949-MD/006).

WALKER, P.H.; WOODYER, K.D.; HUIKA, J. 1974. Particle-size measurements by Coulter Counter of very small deposits and low suspended sediment concentrations in streams. Jour.of Sedim.Petrol, 44 (3) : 673-679.

WOLGEMUTH, K.M.; BURNETT, W.C. ; MOURA, P.L. de.1981. Oceanography and suspended material in Todos os Santos Bay. Rev.Bras.Geoc., $11(3)$.

ZEMBRUSCKI, S.G. ei ąii . 1971. Fisiografia e aistribuição dos se dimentos superficiais da plataforma continental norte brasi leira. Bol.Tec.Petrobräs, Rio de Janeiro, J.4 (3/4): 127-155.

ZEMBRUSCKI, S.G. et alii. 1972. Estudo preliminar das provinvias geømorfológicas da margem continental brasileira. In: CONGRES SO BRASILEIRO de GEOLOGIA, 26, Belëm, 1972. Anais... Belëm, SBG. v.2，p.187-209. 